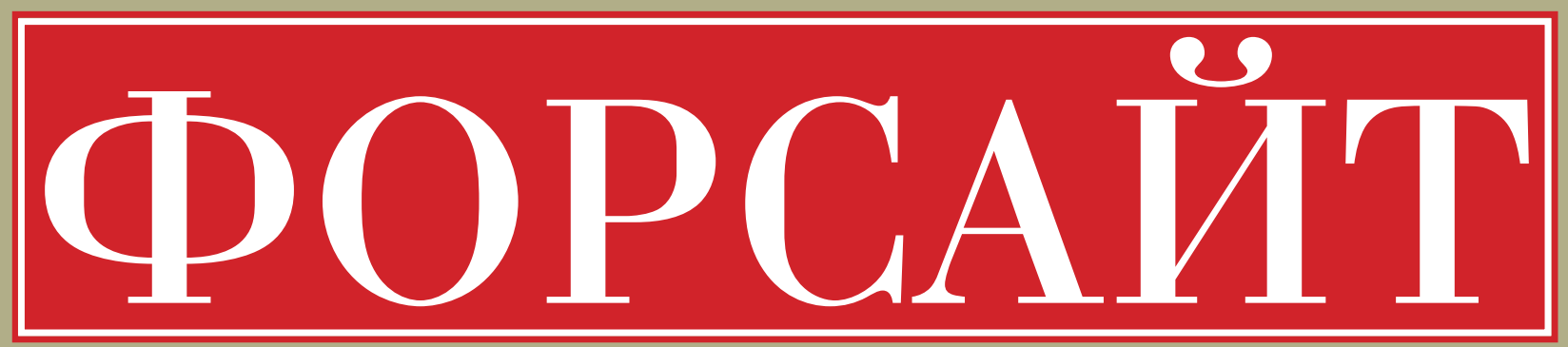

ЖУРНАЛ НАЦИОНАЛЬНОГО ИССЛЕДОВАТЕЛЬСКОГО УНИВЕРСИТЕТА «ВЫСШАЯ ШКОЛА ЭКОНОМИКИ»

T. 5. № 4.2011

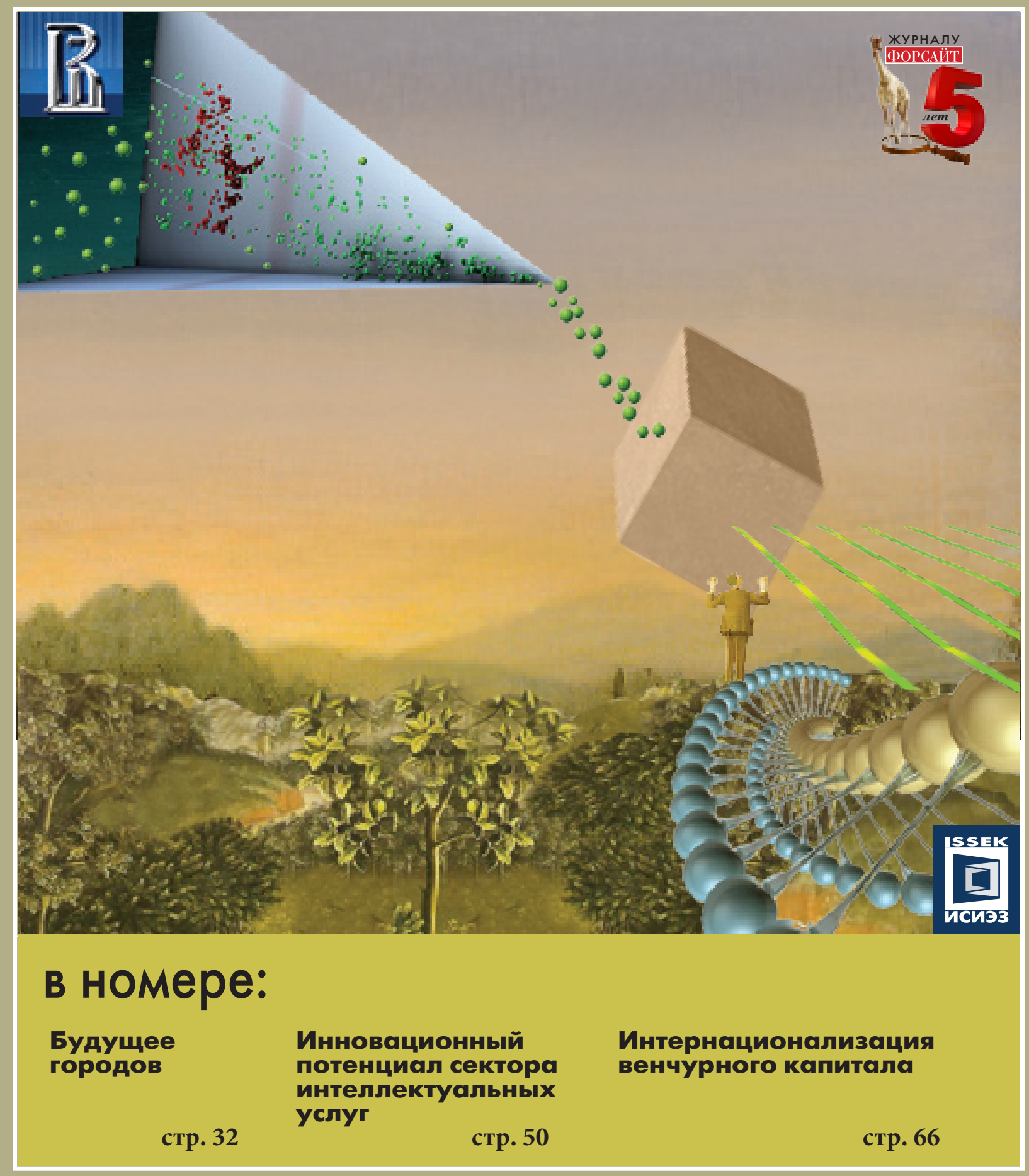

\section{Будущее городов}

стр. 32
Инновационный потенциал сектора интеллектуальных стр. 50
Интернационализация

стр. 66 

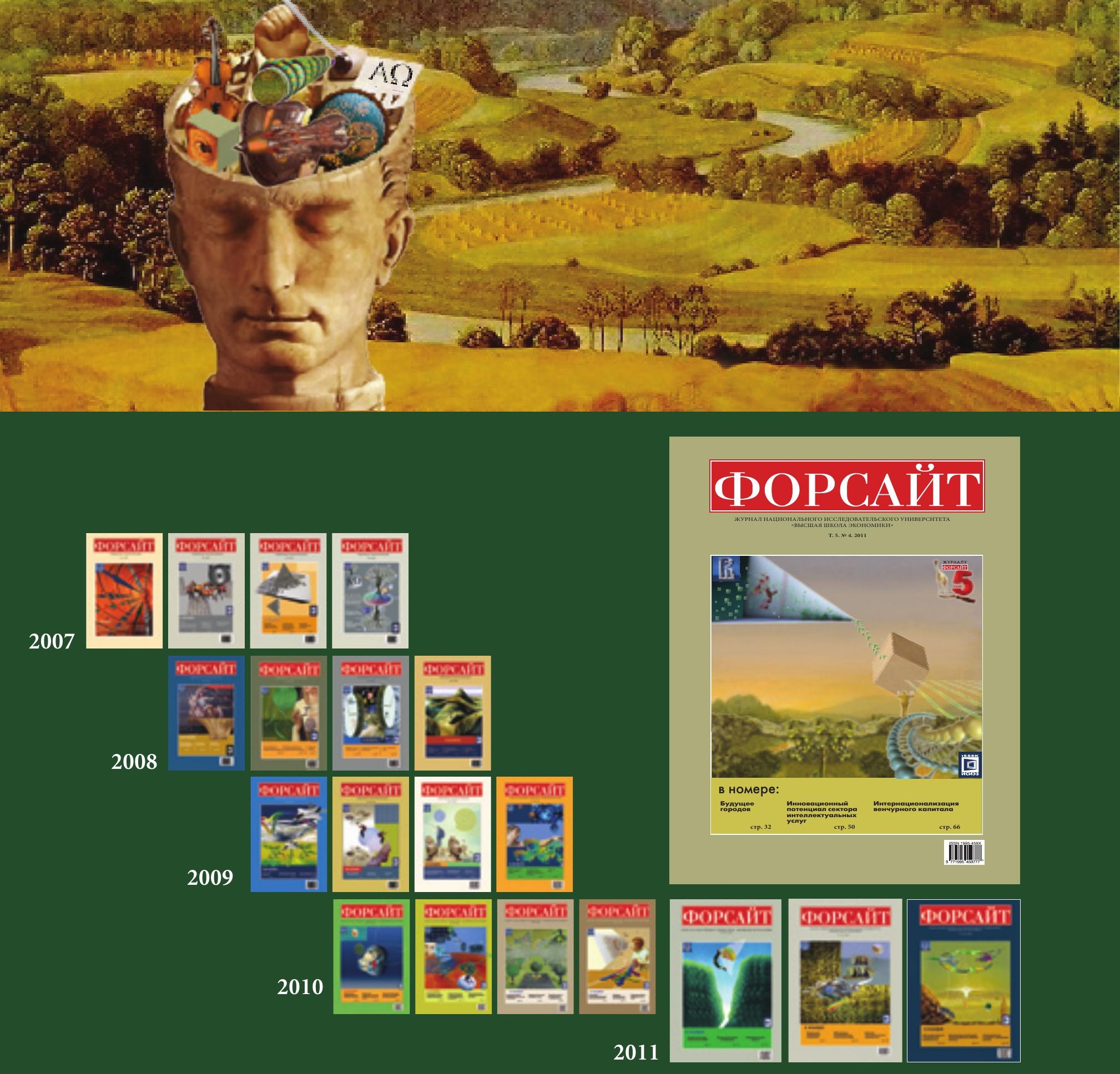

\section{ФОРСАЙТ}




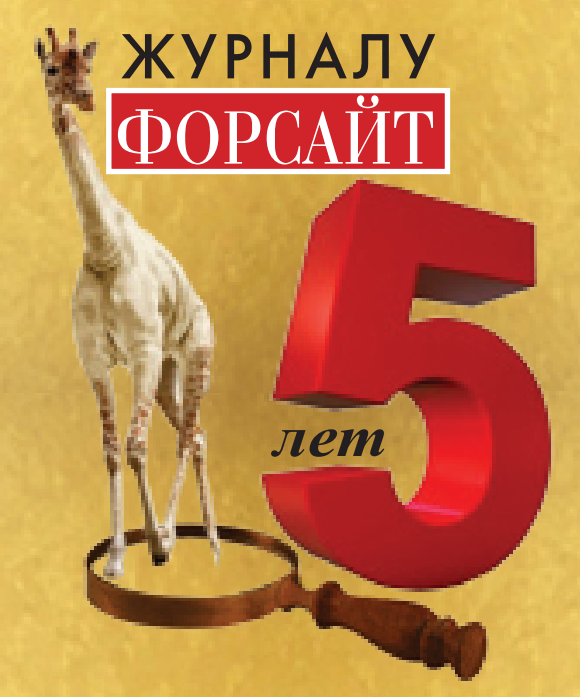

\section{ПОДПИСКА НА ЖУРНАЛ}

Издается с 2007 года

В соответствии с решением Высшей аттестационной комиссии Министерства образования и науки Российской Федерации журнал «Форсайт» включен в перечень ведущих рецензируемых научных журналов и изданий, выпускаемых в Российской Федерации, рекомендованных для публикации основных научных результатов диссертаций на соискание ученой степени доктора и кандидата наук по направлению «Экономика» (протокол заседания президиума ВАК № 6/6 от 19 февраля 2010 г.).

Рейтинг журнала по импакт-фактору в Российском индексе научного цитирования:

- Науковедение - 1

- Организация и управление - 3

- Экономика - 8

\section{ПОДПИСНОЙ ИНДЕКС}

Агентство «Роспечать» 80690

«Пресса России» 42286

Стоимость подписки на полугодие 880 руб. (включая НДС)

Журнал выходит ежеквартально

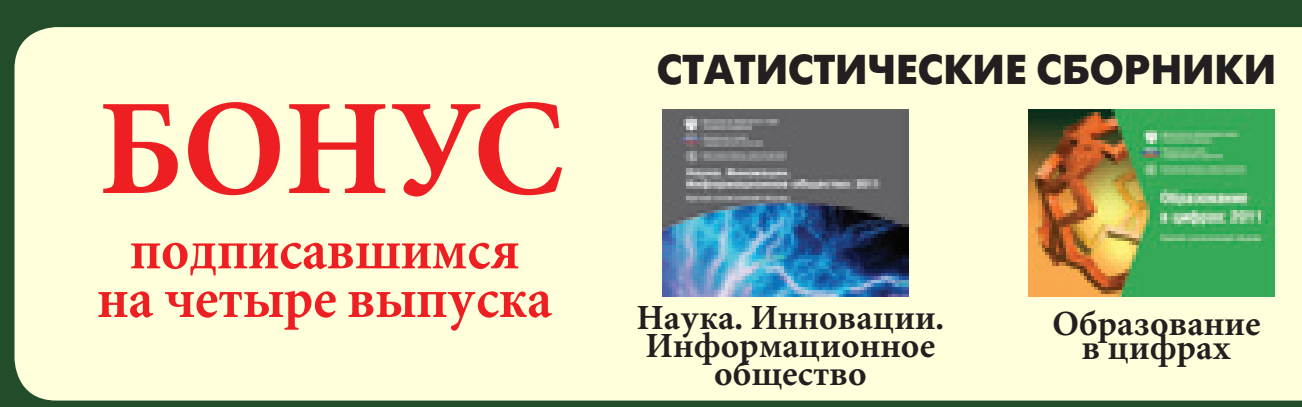

Тел./факс: +7 (495) 624-07-15 F www.foresight-journal.hse.ru 


\section{ФОРСАЙТ}

ЖУРНАЛ НАЦИОНАЛЬНОГО ИССЛЕДОВАТЕЛЬСКОГО УНИВЕРСИТЕТА «ВЫСШАЯ ШКОЛА ЭКОНОМИКИ

Периодичность выхода - 4 раза в год

\section{РЕДАКЦИОННЫЙ СОВЕТ}

Главный редактор - Л.М. Гохберг (НИУ ВШЭ) Заместитель главного редактора - А.В. Соколов (НИУ ВШЭ)

И.Р. Агамирзян (Российская венчурная компания) Л. Бах (Университет Луи Пастера, Франция)

А.Р. Белоусов (Правительство РФ)

Ж. Гине (НИУ ВШЭ)

Р. Зейдль да Фонсека (ЮНИДО)

М. Кинэн (ОЭСР)

А.Н. Клепач (Минэкономразвития России)

М.В. Ковальчук (РНЦ «Курчатовский институт»)

Я.И. Кузьминов (НИУ ВШЭ)

Й. Майлс (НИУ ВШЭ и Университет Манчестера, Великобритания)

С.Г. Поляков (Фонд содействия развитию малых форм предприятий в научно-технической сфере) О. Саритас (Университет Манчестера,

Великобритания)

М. Сервантес (ОЭСР)

А.В. Хлунов (Правительство РФ)

Г. Швайцер (Национальная академия наук США)

К. Шух (Центр социальных инноваций, Австрия)

\section{РЕДАКЦИОННАЯ КОЛЛЕГИЯ}

\section{Т.Е. Кузнецова (НИУ ВШЭ)}

Д. Майсснер (НИУ ВШЭ)

М.В. Рычев (РНЦ «Курчатовский институт»)

Ю.В. Симачев (Межведомственный аналитический центр)

\section{РЕДАКЦИЯ}

\section{Ответственный редактор}

М.В. Бойкова

Литературный редактор

Н.А. Гавриличева

Корректор

Н.В. Яровикова

Художник

М.Б. Зальцман

Верстка

М.Г. Салазкин

\section{Адрес редакции:}

109074, Москва, Славянская пл., 4, стр. 2, оф. 420-421

Национальный исследовательский университет

«Высшая школа экономики»

Телефон: +7 (495) 624-07-15

E-mail: foresight-journal@hse.ru

Web: http://foresight-journal.hse.ru

\section{Учредители:}

Национальный исследовательский университет

«Высшая школа экономики», ООО «Планета:

5 континентов»

Тираж 999 экз.

ISSN 1995-459X

(c) Национальный исследовательский университет

«Высшая школа экономики», ООО «Планета:

5 континентов»

\section{ИНДЕКС}

организаций, упомянутых в номере

Apple

The Climate Group

Compaq

Economist Intelligence Unit

Fairchild Semiconductors

Global Business Network

IBM

Intel

Lotus

Microsoft

Monitor Group

Sun Microsystems

Xerox

Американская корпорация исследований и разработок

(American Research and Development Corporation),

США

Внешэкономбанк

Всемирная организация здравоохранения

Всемирная торговая организация (ВТО)

Высшая аттестационная комиссия Минобрнауки РФ

(ВАК)

Еврокомиссия

Европейская ассоциация венчурного капитала

(European Venture Capital Association)

Европейский банк реконструкции и развития

Евростат

Инвестфонд

Инновационный центр «Сколково»

Институт перспективных технологических

исследований (Institute for Prospective Technology

Studies, IPTS), Испания

Институт статистических исследований

и экономики знаний (ИСИЭЗ) НИУ ВШЭ

Лукойл

Международная ассоциация городского и окружного

управления

Международный валютный фонд

Министерство здравоохранения и социального

развития Р $Ф$

Министерство промышленности и торговли РФ

Министерство связи и массовых коммуникаций РФ

Министерство энергетики РФ

Минэкономразвития России

Национальный исследовательский университет

«Высшая школа экономики» (НИУ ВШЭ)

Национальный центр научных исследований Франции

Объединенный европейский исследовательский центр

(Joint Research Centre, JRC)

$\mathrm{OOH}$

Организация экономического сотрудничества

и развития $(\mathrm{O} С \mathrm{CP})$

Роснано

Роснефть

Российская академия народного хозяйства и

государственной службы при Президенте РФ

(РАНХиГС)

Российская венчурная компания (РВК)

Российский фонд технологического развития

Росстат

Служба технологического оценивания (Office for

Technology Assessment, OTA), США

Совет Мальты по науке и технологиям

Технологический институт штата Джорджия (Georgia

Technology Institute), CША

Университет Лафборо (Loughborough University),

Великобритания

$10,19,23,27,85$

Университет Оттавы (Ottawa University), Канада

Универститет Манчестера (Manchester University),

Великобритания

Федеральная антимонопольная служба (ФАС)

Федеральная комиссия по ценным бумагам

Федеральная налоговая служба

Центр фотохимии РАН

Центр исследований нанотехнологий

и специализированных структур Университета

Аризоны (CNS-ASU), США

Чикагский университет (Chicago University), США

$2,13,31,32,48$ 80-82, 84-86

69 69 


\section{Содержание}

Исследования, аналитика, мастер-класс

\section{Rus Eng}

\begin{tabular}{lll}
\multicolumn{2}{c}{ ENGLISH } & \\
\hline About the journal & - & 4 \\
Contents & - & 5
\end{tabular}

\section{ОТ РЕДАКЦИИ}

Журналу «Форсайт» -5 лет

\section{СТРАТЕГИИ}

Стратегия-2020: новые контуры 830 инновационной политики

Будущее городов: города как 32 агенты глобализации и инноваций

М.В. Бойкова, И.Н. Ильина,

М.Г. Салазкин

Индикаторы 48

ИННОВАЦИИ И ЭКОНОМИКА

Инновационный потенциал сектора интеллектуальных услуг в России $50 \quad 64$ М.Е. Дороченко

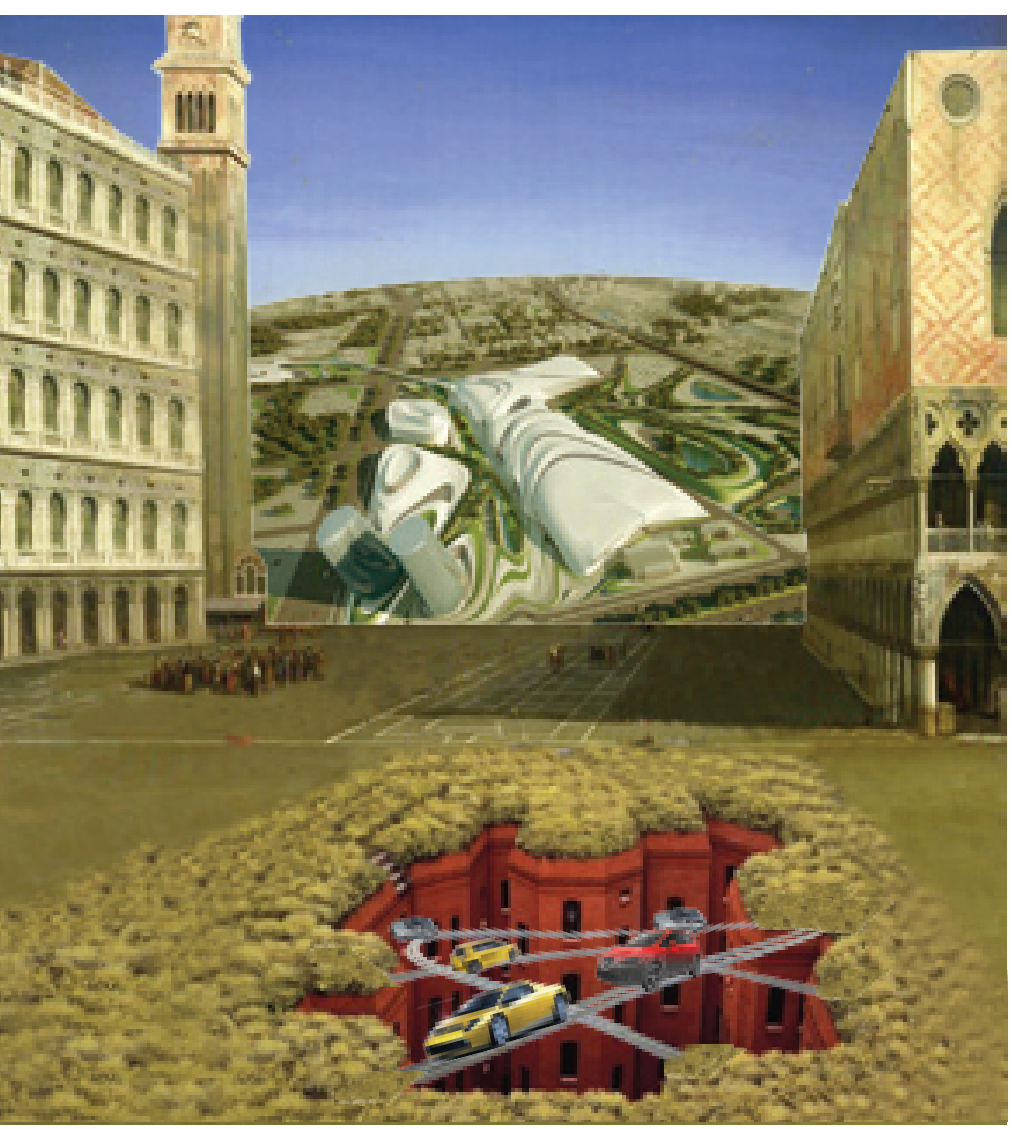

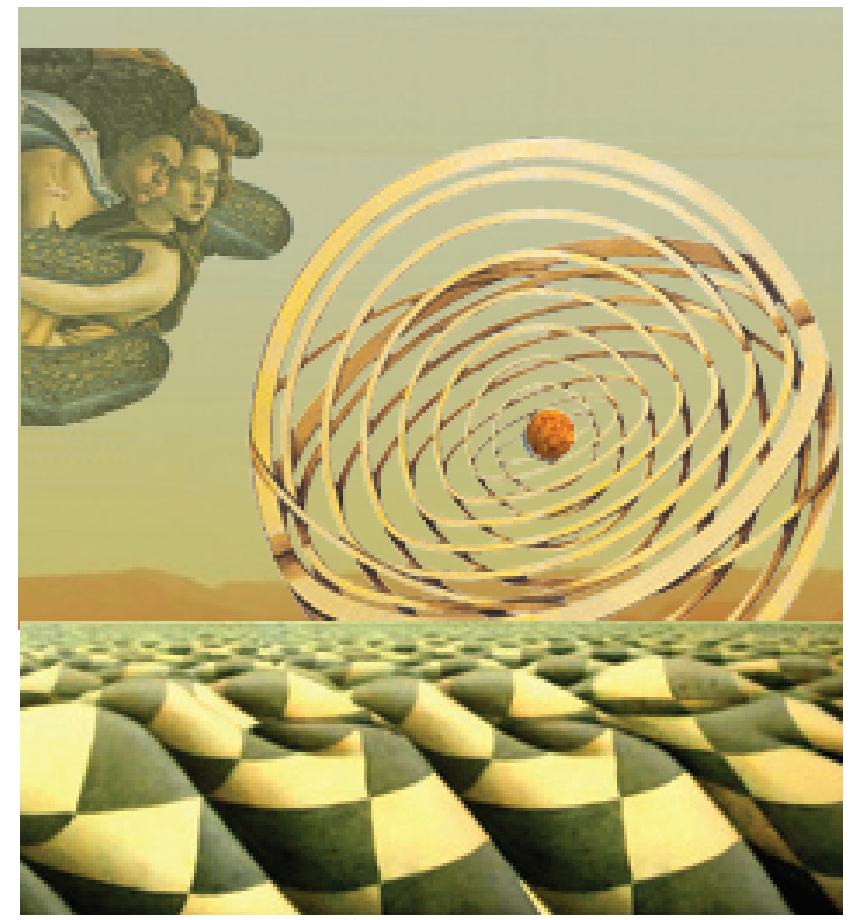

Rus Eng

Интернационализация $66 \quad 75$ венчурного капитала: вызовы и возможности

Т. Гитраунталер, Г.С. Сагиеъа

\section{СОБЫТИЕ}

Международный научный семинар «Форсайт и научно-техническая и инновационная политика: лучший опыт»

\section{МНЕНИЕ ЭКСПЕРТА}

Креативность и взаимодействие: 31 пространства роста для российского Форсайта

Интервью с Л. Джорджиу

Инновации - залог 49 стабильности в период кризиса Интервью с П. Шварием

Эффективный Форсайт: симбиоз экспертизы и фактов Интервью с М.В. Алфимовым 


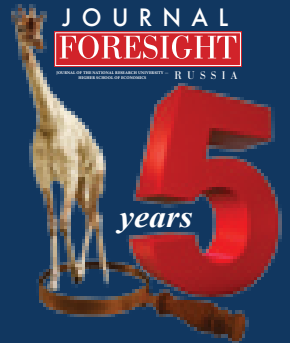

\section{FORESIGHT}

an analytical journal that was established by the National Research University Higher School of Economics (HSE) and is administered by the HSE Institute for Statistical Studies and Economics of Knowledge (ISSEK), located in Moscow, Russia. The mission of the journal is to support the creation of Foresight culture in Russia through the dissemination of the best Russian and international practices in the field of future-oriented innovation development. It also provides a framework for a discussion of S\&T trends and policies. The following key issues are addressed:

- Foresight methodologies

- Results of Foresight studies implemented in Russia and abroad

- Long-term priorities of social, economic and S\&T development

- S\&T and innovation trends and indicators

- S\&T and innovation policies

- Strategic programmes of innovation development at national, regional, sectoral and corporate levels

- State-of-the-art methodologies and best practices of S\&T analyses and Foresight.

The target audience of the journal comprises research scholars, university professors, policymakers, businessmen, expert community, post-graduates, undergraduates and others who are interested in S\&T and innovation analyses, Foresight and policy issues.

The thematic focus of the journal makes it a unique Russian language edition in this field. FORESIGHT is published quarterly and distributed in Russia, CIS countries, and abroad.

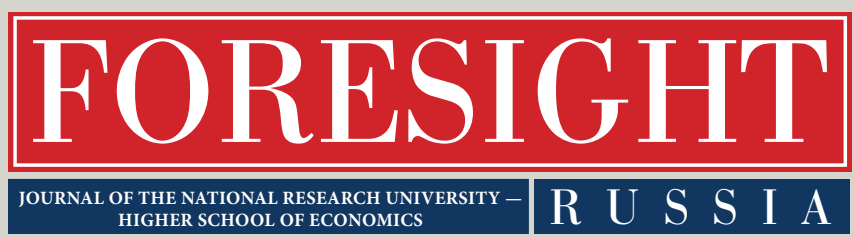

Periodicity-Quarterly

ISSN 1995-459X

EDITORIAL COUNCIL

Leonid Gokhberg, Editor-in-Chief, First Vice-Rector, HSE, and Director, ISSEK, HSE, Russian Federation

Alexander Sokolov, Deputy Editor-in-Chief, HSE,

Russian Federation

Igor Agamirzyan, Russian Venture Company, Russian Federation

Laurent Bach, BETA, University Louis Pasteur Strasbourg, France

Andrey Belousov, Government of the Russian Federation, Russian Federation

Mario Cervantes, Directorate for Science, Technology and Industry, OECD, France

Jean Guinet, HSE, France

Michael Keenan, Directorate for Science, Technology and Industry, OECD, France

Alexander Khlunov, Government of the Russian

Federation, Russian Federation

Andrey Klepach, Ministry of Economic Development

of the Russian Federation, Russian Federation

Mikhail Kovalchuk, Russian Scientific Centre

«Kurchatov Institute», Russian Federation

Yaroslav Kuzminov, HSE, Russian Federation

Ian Miles, HSE, United Kingdom

Sergey Polyakov, Foundation for Assistance to Small

Innovative Enterprises, Russian Federation

Ozcan Saritas, Manchester University, United Kingdom

Ricardo Seidl da Fonseca, UNIDO, Austria

Klaus Schuch, Zentrum für Soziale Innovation, Austria

Glenn E. Schweitzer, US National Academy of Sciences,

United States

\section{EDITORIAL BOARD}

Tatiana Kuznetsova, HSE, Russian Federation

Dirk Meissner, HSE, Russian Federation

Mikhail Rychev, Russian Scientific Centre

«Kurchatov Institute», Russian Federation

Yury Simachev, Interdepartmental Analytical

Centre, Russian Federation

\section{EDITORIAL STAFF}

Executive Editor - Marina Boykova

Literary Editor - Nataliya Gavrilicheva

Proof Reader - Nataliya Yarovikova

Designer - Mariya Salzmann

Pre-Press - Mikhail Salazkin

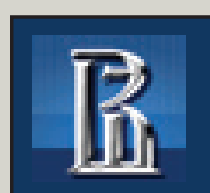

National Research University Higher School of Economics

Institute for Statistical Studies and Economics of Knowledge

Our address:

National Research University - Higher School of Economics»

Office 420-421, 4 bld. 2, Slavyanskaya sq., Moscow, 109074, Russia

Tel: +7 (495) 624-07-15

E-mail: foresight-journal@hse.ru

Web: http://foresight-journal.hse.ru 


\section{CONTENTS}

Vol. 5, № 3 (2011)
CONTENTS

Vol. 5, № 4 (2011)
Rus Eng

INFORMATION

on the Journal in English

INFORMATION

on the Papers in English

STRATEGIES

Globalization of Industrial R\&D

44

$6 \quad 6$

in Developing Countries:

A Sociological Perspective

Binay Kumar Pattnaik

Indicators

\section{SCIENCE}

Scientific Capital as a Driver of Researchers' Social Mobility

Natalya Shmatko

Indicators

«Invisible» Science: Patterns of Internationalisation for the

Russian Scientific Publications

Olesya Kirchik

\section{Indicators}

S\&T Cooperation between

529

the EU and Ukraine: Benefits

and Barriers

Michael Le Gohebel, Désirée Pecarz,

Katharina Handler, Klaus Schuch

\section{MASTER CLASS}

Seeing the Invisible and Making $66 \quad 10$ Sense of It. Scanning, Networks and Scenario Analysis

Yanuar Nugroho, Ozcan Saritas

\section{EVENT}

The Second German-Russian $78 \quad 11$

Summer School «Science, Technology and Innovation Development»
Rus Eng

Contents

INFORMATION

on the Journal in English

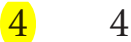

EDITORIAL

Journal "Foresight": Five Years

6

STRATEGIES

Strategy 2020: New Outlines

$8 \quad 30$

of Innovation Policy

Urban Futures: Cities as Agents

$32 \quad 47$

of Globalization and Innovation

Marina Boykova, Irina Ilyina,

Mikhail Salazkin

Indicators

INNOVATION AND ECONOMY

Innovative Potential of the

Knowledge-Intensive Services

Sector in Russia

Marina Doroshenko

The Internationalization of

Venture Capital: Challenges and

Opportunities

Thomas Gstraunthaler, Galina Sagieva

\section{EVENT}

International Research

Workshop «Foresight and

Science, Technology and

Innovation Policies: Best

Practices»

\section{EXPERT OPINION}

Creativity and Interaction as

Areas of Growth for the Russian

Foresight

Interview with Luke Georghiou

Innovation as a Basis of Stability

in the Times of Crisis

Interview with Peter Schwartz

An Efficient Foresight Study:

Mutualism of Expertise and

Evidence

Interview with Mikhail Alfimov 


\section{"Фурналу

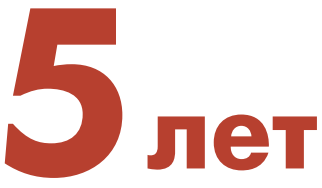

\section{Уважаемые читатели!}

Вы держите в руках юбилейный — двадцатый — номер журнала «Форсайт», который издается Национальным исследовательским университетом «Высшая школа экономики» с 2007 г.

Все эти годы редколлегия и редакция стремились как можно лучше решать наиважнейшую, на наш взгляд, задачу - создание в России высококачественного научного журнала по экономике, статистике, социологии, политике в сфере науки, технологий и инноваций, методологии и практике Форсайт-исследований, который стал бы творческой площадкой для публикации, распространения и обсуждения новейших идей, взглядов, подходов, аналитических результатов.

Издание освещает широкий спектр тем, связанных с теориями инноваций и долгосрочного прогнозирования; исследованиями тенденций научнотехнологического и инновационного развития на глобальном, национальном, региональном и корпоративном уровнях, моделей инновационного поведения экономических акторов; формированием и реализацией научно-технической и инновационной политики.

За прошедшее пятилетие структура и формат журнала, естественно, менялись в направлении повышения культуры подачи материалов, расширения научного и информационного контекста. Неизменными остались его концепция и ключевые принципы. Речь идет о фокусировке на заявленной тематической области и ориентации на динамизм ее развития на глобальной арене, междисциплинарности, интеграции в международные исследовательские сети, высоких требованиях к качеству публикаций. Не будем скрывать, что добиться этого оказалось совсем не просто и многое еще предстоит сделать. Но упорная работа редколлегии и редакции по улучшению содержательного наполнения журнала и развитию профессиональных коммуникаций позволила своевременно среагировать на появление перспективных исследовательских направлений, на зарождающиеся тренды, зачастую предвосхищая их публичное признание; превратить «Форсайт» в своего рода проводник усложняющейся модели научнотехнологического и социально-экономического развития.

Именно на страницах нашего журнала впервые в России максимально широко, на систематической основе стали анализироваться межстрановые, национальные, региональные, отраслевые и корпоративные Форсайт-проекты; получила освещение проблематика открытых и инклюзивных инноваций, интеллектуальных услуг, инновационных режимов, центров превосходства в сфере науки, картирования технологий и др. В следующем году мы начнем публиковать материалы исследований в рамках подготовки долгосрочного прогноза научно-технологического развития на период до 2030 г.

Важной миссией журнала мы считаем содействие становлению в России профессиональной культуры в рассматриваемой области и воспитанию нового поколения исследователей, ориентированных на международные стандарты научной деятельности. Стараемся даже формировать авторов из числа перспективных молодых ученых, исследования которых находятся в нашем поле зрения. 
Бесценный вклад в развитие журнала вносит редакционный совет, который состоит из ведущих российских и зарубежных специалистов, экспертов в областях, охватываемых тематикой «Форсайта». С их помощью удалось выстроить научные приоритеты журнала; добиться удачного, по нашему мнению, соотношения между теоретическими и прикладными исследованиями; сформировать сбалансированную структуру рубрик (стратегии - инновационная экономика - наука - мастер-класс - статистический анализ и индикаторы); организовать пул авторов, включающий известных исследователей, практиков, организаторов науки; интегрировать журнал в международное экспертное сообщество. Примерно 40\% научных статей, появившихся на страницах «Форсайта», подготовлены зарубежными коллегами, причем это - не перепечатки из иностранных изданий, а специально написанные для нас оригинальные тексты. Таким образом, есть все основания считать, что журнал становится все более заметной точкой на «научной» карте мира.

Журнал активно сотрудничает со многими российскими, зарубежными и международными организациями, включая научные издания. В числе наиболее активных партнеров - издающийся в Великобритании и хорошо известный в мире одноименный журнал Foresight, с которым заключено соглашение о партнерстве, вступающее в силу в 2012 г. Оба журнала намереваются активно обмениваться статьями, совместно готовить специальные выпуски, посвященные актуальным исследовательским темам.

Всю текущую работу по сбору и подготовке материалов для публикаций, формированию и изданию каждого номера осуществляют коллективы редакции и редколлегии, каждый из которых состоит всего из нескольких человек. Все они с большой любовью и ответственностью относятся к журналу, постоянно работают над совершенствованием тематики, поиском новых авторов, повышением качества статей, полиграфии и оперативности его издания.

Сегодня можно с уверенностью сказать, что журнал «Форсайт» занял и удерживает определенную нишу в профессиональном информационном пространстве. Не станем утверждать, что он абсолютно уникален, но интерес к нему со стороны как читателей, так и потенциальных авторов год от года растет. Несмотря на сложность обретения узнаваемости на столь насыщенном информационном поле, у журнала уже сложилась устойчивая целевая аудитория, в том числе среди молодых исследователей, преподавателей, аспирантов и студентов.

За достаточно короткий период своего существования «Форсайту» удалось добиться определенного уровня влияния. Об этом свидетельствуют не только вхождение журнала в известный список ВАК, но и его рейтинги по версии Российского индекса научного цитирования: первая позиция в рубрике «Науковедение», третья в рубрике «Организация и управление» и восьмая - по экономике. Но мы не собираемся останавливаться на достигнутом: следующий намечаемый нами рубеж - продвижение «Форсайта» в международные индексы научных журналов. С этой целью внесены определенные изменения в аннотирование статей, оформление библиографии и т. п.

Поздравляя коллег и друзей со скромным юбилеем журнала «Форсайт», выражаем искреннюю благодарность всем, кто оказывал нам поддержку в течение этих пяти лет. Особая признательность - Ярославу Ивановичу Кузьминову, чьей личной инициативе и настойчивости журнал обязан самим своим появлением.

Редколлегия

Редакиия 


\section{Стратегия-2020}

\section{Новые контуры российской инновационной политики}

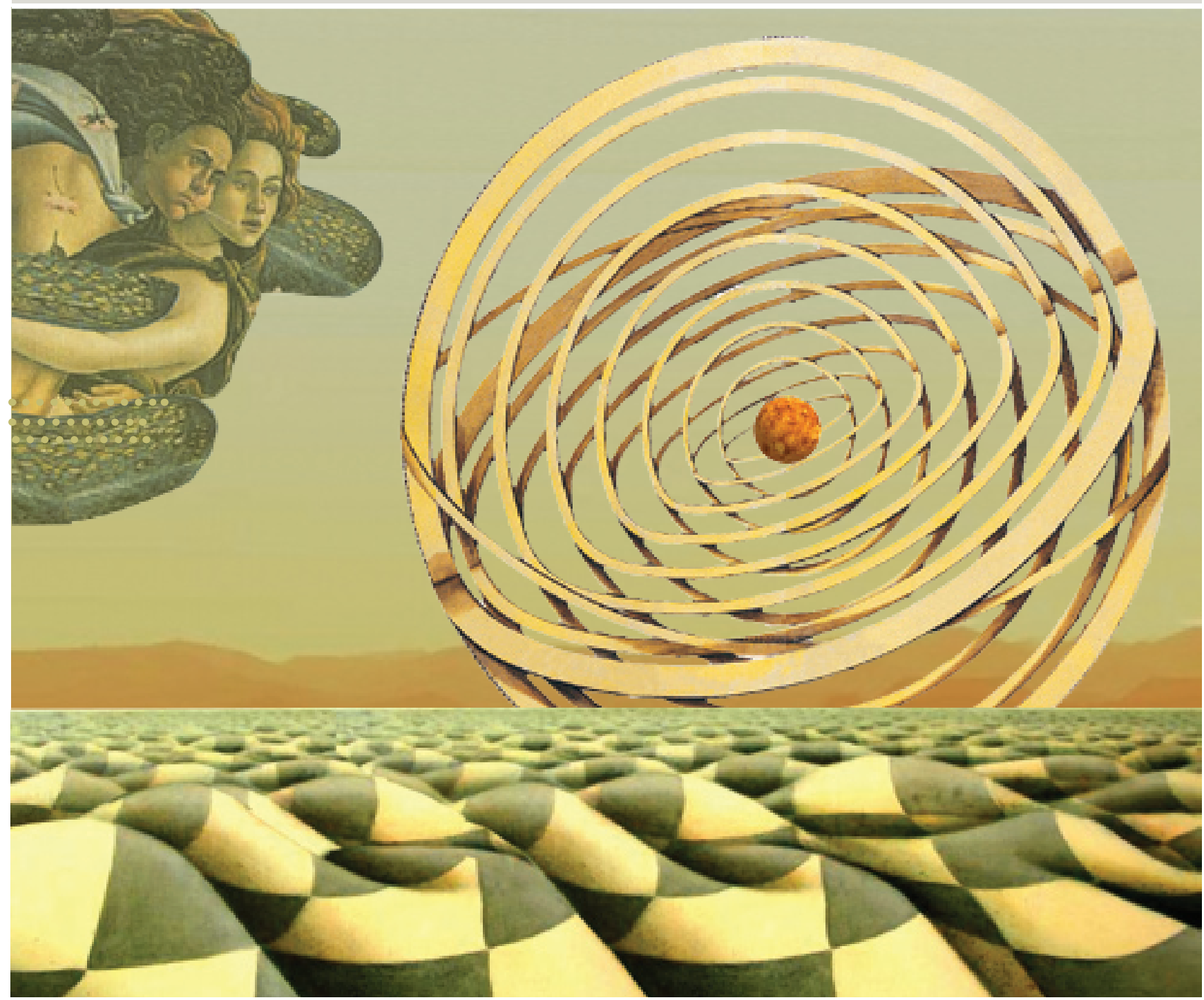

В начале 2011 г. по решению Председателя Правительства РФ был сформирован ряд тематических экспертных групп для подготовки рекомендаций по актуальным проблемам социально-экономической стратегии развития страны на период до 2020 г. Среди них - группа № 5 «Переход от стимулирования инноваций к росту на их основе» (руководители - Л.М. Гохберг, И.Р. Агамирзян), в состав которой вошли ведущие российские и зарубежные эксперты, представители науки, университетов, институтов развития, бизнеса.

В статье кратко излагаются итоги ее деятельности. ${ }^{1}$ 


\section{Инновации - ключевая движущая сила экономического роста}

Становление современной модели социально-экономического развития в значительной мере обусловлено изменением экономической роли инноваций, темпов, направлений и механизмов реализации инновационных процессов. Формирование инновационных экономик стало результатом как ускорения прогресса науки и технологий, так и фундаментальных изменений в международном разделении труда в контексте глобализации.

Эмпирический анализ динамики стран ОЭСР свидетельствует, что уже на рубеже 2000-х гг. нововведения стали «ключевой движущей силой более продуктивного экономического роста» [OECD, 2000, p. 7-8]. Эффекты глобального спада 2008-2010 гг. привели к усилению внимания бизнеса, государства и общества к вопросам развития инноваций в качестве «ключа к выходу из... кризиса», в том числе за счет «созидательного разрушения»: усиления конкурентных преимуществ компаний, активно осуществляющих инвестиции в исследования и разработки (ИиР), осваивающих новые технологии и модели ведения бизнеса. Этому, в свою очередь, способствовала быстрая реакция национальных правительств - появление «проинновационных» антикризисных программ, планов восстановления экономики, специальных законодательных и нормативных актов, предусматривающих стимулы для создания и использования инновационных технологий, продуктов и услуг [OECD, 2009, p. 5-10]. В посткризисный период поиск новых подходов к инновационной политике и мер по ее реализации в целях обеспечения устойчивого экономического роста продолжился.

В США приняты законы о срочной экономической стабилизации (Polson Act, 2008), о восстановлении экономики и новых инвестициях (American Recovery and Reinvestment Bill, 2009), предусматривающие, в частности, поддержку инноваций, связанных с энергоэффективностью (включая переход на чистые источники энергии), инвестиций в информационные и коммуникационные технологии (ИКТ), исследований в области охраны окружающей среды; модернизацию транспортной инфраструктуры; развитие локальных инновационных систем. Решено отказаться к 2015 г. от государственных закупок автомобилей с бензиновыми двигателями, сократить - на треть к 2025 г. - импорт энергоносителей (выступление Б. Обамы 30.03.2011).

В 2011 г. Европейским Союзом принята инновационная стратегия на ближайшее десятилетие, в которой намечены новые направления политики в этой сфере [European Commission, 2010].

Еще в разгар кризиса, несмотря на серьезные проблемы, большинство глобальных компаний не отказались от инноваций и не сократили расходы на науку. Более того, 40\% из них запланировали наращивание этих затрат, в том числе на базе кооперации с университетами (2009 Global R\&D Funding Forecast, 2008).
Взаимозависимость развитых и развивающихся экономик, новая ситуация в международном разделении труда и глобальной конкуренции важны для понимания природы, значимости и задач развития инновационной сферы России. В силу высоких внутренних издержек, включая оплату труда, конкурентоспособность отечественного массового промышленного производства ограничена. В то же время достаточно высокое качество человеческого капитала и сохранившийся научный потенциал открывают перед страной возможности для того, чтобы занять определенные ниши на рынке технологий. Россия объективно интегрирована в мировую экономику и глобальное научно-технологическое пространство, но уровень этой интеграции пока невысок и ограничен «нижними этажами» глобальной кооперации (поставки сырья и энергоресурсов), а также донорством креативных идей и их создателей, не находящих признания на родине. Между тем, полноценное, эффективное участие в глобальных процессах, помимо собственно экономических эффектов, само по себе является важнейшей ценностью для активных групп предпринимателей и населения в целом (образованного класса, молодежи). Любые попытки «закрыть» внутренний рынок и технологическое пространство контрпродуктивны, поскольку обрекают Россию на устойчивое позиционирование в группе аутсайдеров инновационного процесса: по оценке Глобального инновационного индекса за 2010 г., она занимает в этом распределении 64-е место среди 132 стран мира [Dutta, 2011].

В развитых государствах сложилась успешная практика поддержки инновационной сферы, которая обобщена в Инновационной стратегии ОЭСР [OECD, 2010a], базирующейся на нескольких ключевых установках, актуальных и для нашей страны:

- Инновации - сложное явление, развивающееся на стыке экономических и социальных отношений (институтов) и предусматривающее реализацию исследовательских, технологических, маркетинговых, внедренческих, организационных и финансовых мероприятий. Их специфика определяет требования к комплексности регулирования соответствующих видов деятельности.

- Усиление экономических, демографических, энергетических, финансовых и других глобальных вызовов и внутренних ограничений означает абсолютный приоритет в повестке государственной политики мер, нацеленных на рост эффективности использования ресурсов во всех сегментах экономики и всеми экономическими акторами.

- Использование потенциально эффективных «инновационных регуляторов» невозможно при сохранении контринновационных зон политики. В отечественной практике к их числу, в частности, следует отнести налоговое администрирование, таможенное регулирование, систему государственных закупок и др.

- В условиях объективных (и зачастую очень жестких) бюджетных ограничений должны решаться две взаимосвязанные задачи - активное привлечение в сферу науки и инноваций средств бизнеса, 
в том числе из-за рубежа, и повышение доходности соответствующих видов деятельности и секторов. В России эти проблемы крайне актуальны, поскольку основным источником финансирования данной сферы остаются - прямо или опосредованно - средства федерального бюджета, отдача от которых низка.

- Значимость инноваций усиливается в связи с необходимостью решения обостряющихся глобальных проблем - экология, болезни, обеспечение растущего населения продовольствием и водой, социальная стабильность и др. Социальная ориентированность инноваций на повышение качества жизни и расширение возможностей граждан обусловливает новые приоритеты как для бизнеса, так и для государственной политики.

\section{Сложившаяся ситуация и проблемы развития инновационной сферы в России}

Несмотря на определенный потенциал в области человеческого капитала и научных достижений, развитие инновационных процессов в России находится на низком уровне. Малочисленны инновационные разработки предприятий, слаба патентная активность, наука продолжает функционировать в рамках традиционной («советской») модели, оторванной от бизнеса и образования. Государство поддерживает традиционные высокотехнологич ные сектора; за рамками политики остаются задачи «массовизации» инноваций, развития нетехнологи ческих, экологических, социальных инноваций.

За последние годы в России созданы основные элементы инновационной инфраструктуры; в изобретательскую и внедренческую деятельность вовлечено значительное число ученых и предпринимателей; успешный опыт демонстрируют ряд инновационноактивных регионов.

Инновационная повестка вошла в состав первоочередных приоритетов социально-экономической политики, включена в основные стратегические документы государства. Созданы координационные органы высокого уровня при Президенте и Председателе Правительства Российской Федерации. Завершено номинальное формирование системы институтов развития, нацеленной на создание «инновационного лифта» в российской экономике (Российская венчурная компания, Роснано, Российский фонд технологического развития, Внешэкономбанк, Сколково и др.). Запущена масштабная программа мер по поддержке вузовского сектора науки, включая создание национальных исследовательских университетов и формирование программ их развития, привлечение в вузы ведущих ученых, поддержку исследовательской кооперации вузов с компаниями реального сектора экономики, программ развития инновационной инфраструктуры вузов. Предпринята попытка «принуждения к инновациям» крупных госкомпаний: сформированы программы инновационного развития, где предусмотрены их обязательства по повышению инновационной активности, увеличению затрат на науку, усилению кооперации с вузами. Введены в действие новые инструменты инновационной политики: налоговые льготы для инновационных компаний, создание малых инновационных предприятий при вузах и НИИ, технологические платформы и др.

Однако, как будет показано ниже, добиться существенных сдвигов пока не удалось: инновационные процессы по-прежнему слабо влияют на социальноэкономический прогресс, характеризуются множеством структурных, ресурсных и институциональных проблем и диспропорций. Они находятся в состоянии длительной и устойчивой стагнации, что обусловлено неблагоприятными макроэкономическими условиями, сложившейся структурой рынков, качеством корпоративного управления, с одной стороны, и недостаточной эффективностью национальной инновационной системы (НИС) и ее институтов, с другой [Российский инновационный индекс, 2011; Гохберг и др., 2011; Инновационное развитие..., 2008].

По уровню инновационной активности предприятий, который с начала 2000-х гг. не превышает 10\% (рис. 1), Россия уступает не только ведущим индустриальным странам, но и государствам Восточной Европы. Причем это касается как технологических, так и нетехнологических (организационных, маркетинговых) инноваций, степень интенсивности которых вдвое ниже (рис. 2).

- Существенна отраслевая дифференциация инновационной активности: в высокотехнологичных секторах (фармацевтика, производство компьютерного, телекоммуникационного оборудования, авиакосмической техники) доля инновационно-активных предприятий достигает 23-36\%; в добывающих и подавляющем большинстве обрабатывающих производств - только 2-11\%. В результате расслоение экономики по разным технологическим укладам усиливается. Инновационная пассивность в традиционных отраслях грозит дальнейшим снижением национальной конкурентоспособности [Гохберг, Кузнецьова, 2009].

- Для России характерна низкая интенсивность затрат на инновации в соотношении с объемом продаж: в среднем по промышленности - $1.9 \%$ (в Швеции 5.5\%, Германии - 4.6\%). Не впечатляет и их отдача: рост затрат не сопровождается повышением доли инновационной продукции в общем объеме производства, которая в течение 1995-2010 гг. сохранялась на уровне примерно $5 \%$.

- Бизнес предъявляет невысокий спрос на инновации. Как вид предпринимательства они не являются для российских компаний безусловным приоритетом. Только 2\% предприятий промышленности ориентированы на зарубежные рынки; продукция остальных в основном реализуется на локальных рынках, отличающихся низким уровнем конкуренции и нерыночными ограничениями, в силу чего у большинства компаний отсутствуют устойчивые стимулы к новаторству. Горизонт планирования в бизнес-секторе, как правило, не превышает 3-5 лет; нет заинтересованности в долгосрочном прогнозировании; не предъявляется масштабный спрос на достижения науки и технологий, в том числе отечественные. Поэтому, 


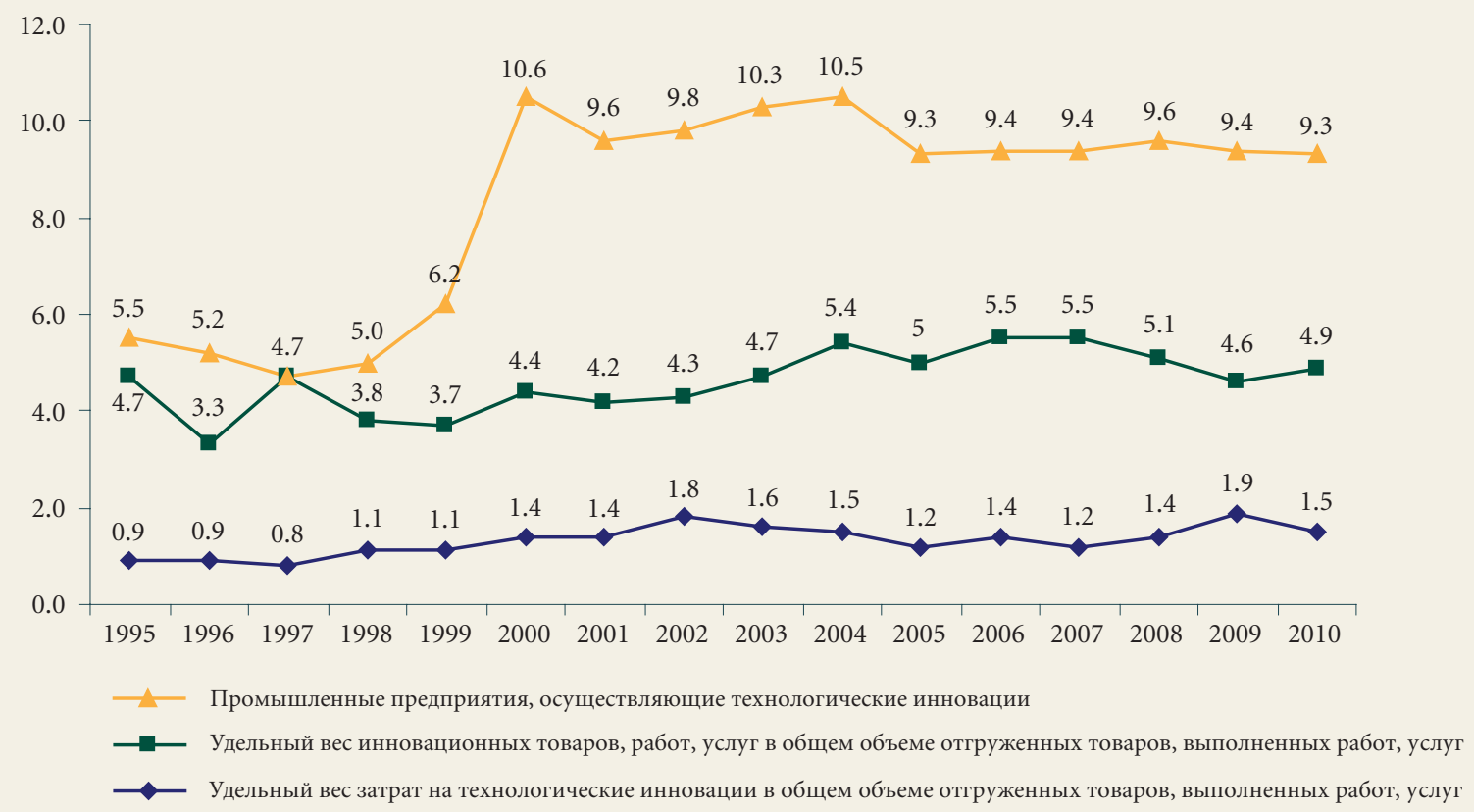

несмотря на реализацию самых разнообразных инициатив государства, недостаточные мотивация и спрос со стороны традиционных отраслей, неурегулированная до конца система взаимодействия компаний с сектором ИиР, а, следовательно, и неэффективная система целеполагания для его субъектов продолжают выступать серьезным барьером для реализации целей и задач инновационной политики. Поддержка государства, позволяя реализовать «точечные» технологические проекты, не меняет общий настрой бизнеса, не способствует улучшению инновационного климата, развитию массовых современных производств.

- Инновационная деятельность реализуется преимущественно за счет приобретения машин и

\section{Рис. 2. Инновационная वктивность предприятий: международные сопоставления (\%)}

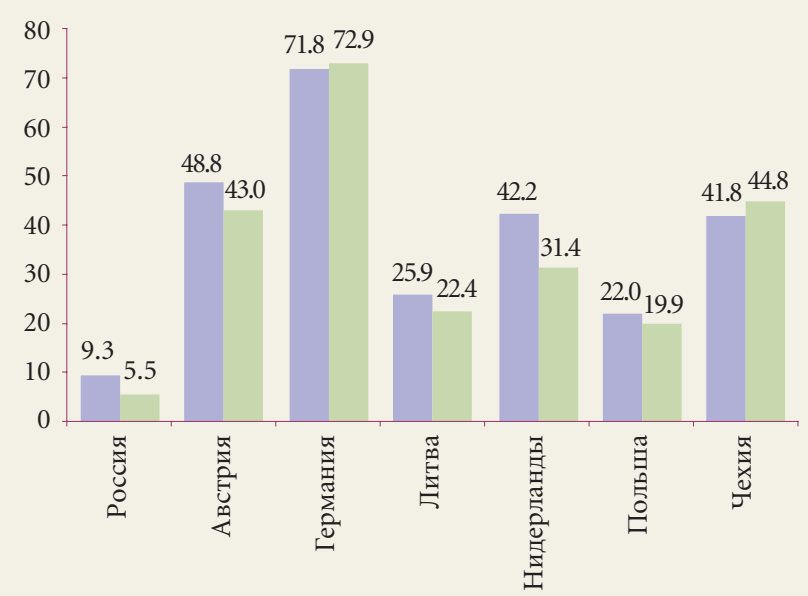

Предприятия промышленного производства, осуществляющие

$$
\square \text { технологические инновации }
$$$$
\square \text { нетехнологические инновации }
$$

оборудования, а не проведения ИиР и создания на этой основе заделов для разработки радикальных новшеств (рис. 3). Такая модель обычно характерна для стран с фрагментарной НИС и сравнительно низким уровнем ее развития. Доля новой для рынка инновационной продукции составляет лишь $0.8 \%$ в общем объеме отгруженной продукции (в Германии - 3.3\%, Финляндии - 6.3\%); остальная ее часть - вновь внедренные или подвергавшиеся значительным технологическим изменениям инновационные товары, работы, услуги, новые для предприятия, но не новые для рынка - составляет 2.1\% в общем объеме отгруженной продукции (в Германии - 14.1\%, Финляндии - 9.3\%).

\section{Рис. з. Структура затрат на инновации (\%)}

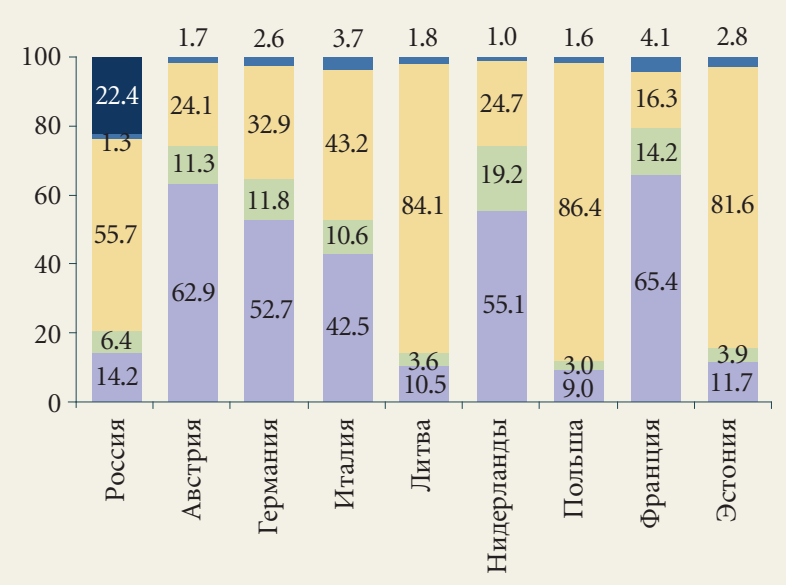

$\square$ ИиР, выполненные собственными силами

$\square$ ИиР, выполненные сторонними организациями

$\square$ Приобретение машин и оборудования, ПС

$\square$ Приобретение новых технологий

口 Прочие затраты 
- Многолетняя стагнация инновационного комплекса проявляется в отсутствии критической массы инноваторов различных типов, обеспечивающих импульсы к развитию НИС «снизу». Хуже всего дело обстоит со стратегическими игроками, занимающимися разработкой и внедрением радикальных нововведений, ориентированных на международные рынки и непосредственно обусловливающих глобальную конкурентоспособность экономики. По расчетам ИСИЭЗ НИУ ВШЭ, лишь одна из десяти инновационных компаний относится к категории инноваторов на международном рынке (в Корее, Германии, Франции, Великобритании 31-36\%, Нидерландах и Финляндии - 40-44\%) [Гохберг u др., 2010].

Российская НИС характеризуется сохранением разрывов между наукой, образованием и бизнесом, слабым уровнем сетевой кооперации, составляющей основу инновационного роста в ведущих странах. Не получил развития институт инновационных рыночных посредников; отсутствуют, либо не полностью сформированы устойчивые инновационные кластеры - отраслевые и региональные. Слабость кооперационных связей препятствует возникновению синергетических эффектов от усилий отдельных инновационных предприятий и организаций.

Определенным преимуществом инновационной сферы остается качество человеческого капитала, которое котируется в целом выше, чем общий уровень инновационной активности (38-е место в Глобальном инновационном индексе, в том числе по качеству высшего образования - 19-е). На фоне 64-го места по уровню инновационного развития эти цифры указывают на масштабы недоиспользованного интеллектуального потенциала.

Нарастают расхождения между структурой и качеством подготовки профессиональных кадров и потребностями инновационной экономики. Мизерны масштабы корпуса высококвалифицированных инженеров, инновационных предпринимателей и менеджеров, а многие конкурентоспособные выпускники вузов, не находя применения в сфере науки и высоких технологий, вынуждены переквалифицироваться либо уезжать за рубеж для работы или завершения образования с получением международно-признанного диплома.

- Отечественная наука продолжает функционировать в рамках архаичной институциональной модели, не отвечающей современным реалиям. В ее институциональной структуре доминируют самостоятельные научные организации, юридически обособленные от вузов и предприятий. На них приходится около 80\% затрат на науку, тогда как в развитых рыночных экономиках костяк НИС составляют университеты и компании. Почти 3/4 организаций, выполняющих ИиР в России, находятся в собственности государства. Прикладная наука представлена преимущественно непромышленными фирмами (их насчитывается не более 7\% от общего числа организаций, выполняющих ИиР), а отраслевыми НИИ и КБ. Исследованиями занимаются 45\% вузов, которые осваивают примерно 8\% затрат на науку (в 2.5 раза ниже среднего показателя по странам ОЭСР).
- На этом фоне центры производства современных знаний и технологий в ряде областей перемещаются в негосударственный сектор, где формируется новый сегмент инновационно-технологических фирм, объединяющий быстрорастущие инновационные компании. Многие из них сосредоточены в перспективных научно-технологических областях (ИКТ, биотехнологии, приборостроение, интеллектуальные услуги и др.), встроены в глобальные цепочки создания стоимости, но ориентированы преимущественно на зарубежных заказчиков. Феномен подобных компаний требует учета и тиражирования в практике государственной инновационной политики.

- Поддержка науки из средств федерального бюджета за период 1998-2010 гг. в постоянных ценах выросла четырехкратно (рис. 4), достигнув по абсолютным объемам уровня Франции и Италии и уже опередив Великобританию и Канаду, однако это не сказывается на динамике ее результативности в части не только прикладных, но и - все в большей степени - фундаментальных исследований. Так, если по числу научных публикаций в международных журналах в начале 2000-х гг. Россия занимала 9-ю позицию, то к концу десятилетия - 16-ю, а по цитируемости - 27-ю. Почти нулевой рост демонстрирует и патентная активность, причем число наиболее ценных патентов триадных патентных семей - остается мизерным на фоне глобальных конкурентов (рис. 5). Научные центры, как правило, не способны предложить бизнесу в массовом порядке готовые к практическому применению технологически конкурентоспособные и рентабельные разработки, обеспечить их сопровождение на стадии освоения. Наращивание бюджетных расходов не сопровождается адекватным вкладом бизнеса: напротив, доля предпринимательского сектора в финансировании ИиР в 2000-2010 гг. сократилась с 33\% до $26 \%$, тогда как в среднем по странам ОЭСР она составляет 65\%, ЕС-27 - 55\%. В итоге технологические заимствования становятся «мейнстримом», обрекая экономику на модель догоняющего развития.

- Несмотря на интенсивный рост бюджетных расходов в целом сохраняется проблема недофинансирования науки. Общие затраты на ИиР в России в 2010 г. достигли лишь 54\% от уровня 1990 г. По уровню удельных затрат на науку в ВВП (1.16\% в 2010 г.) Россия входит в третью десятку стран мира; по абсолютным масштабам затрат она отстает от США в 17 раз, Китая - в 5, Германии - в 4, Франции и Кореи - в 2 раза.

Следствием отмеченных выше, а также других тенденций, рассмотрение которых требует отдельного исследования, является низкая конкурентоспособность отечественной НИС, большинства образующих ее компаний, научных организаций, вузов не только в глобальном пространстве, но зачастую и внутри страны. По масштабам экспорта технологий Россия в разы уступает даже небольшим европейским государствам (Венгрии, Финляндии и др.), а ее доля на мировом рынке высокотехнологичной продукции 0.25\% - статистически не значима (рис. 5).

Таким образом, в России слабый спрос на инновации сочетается с многолетней стагнацией научно- 


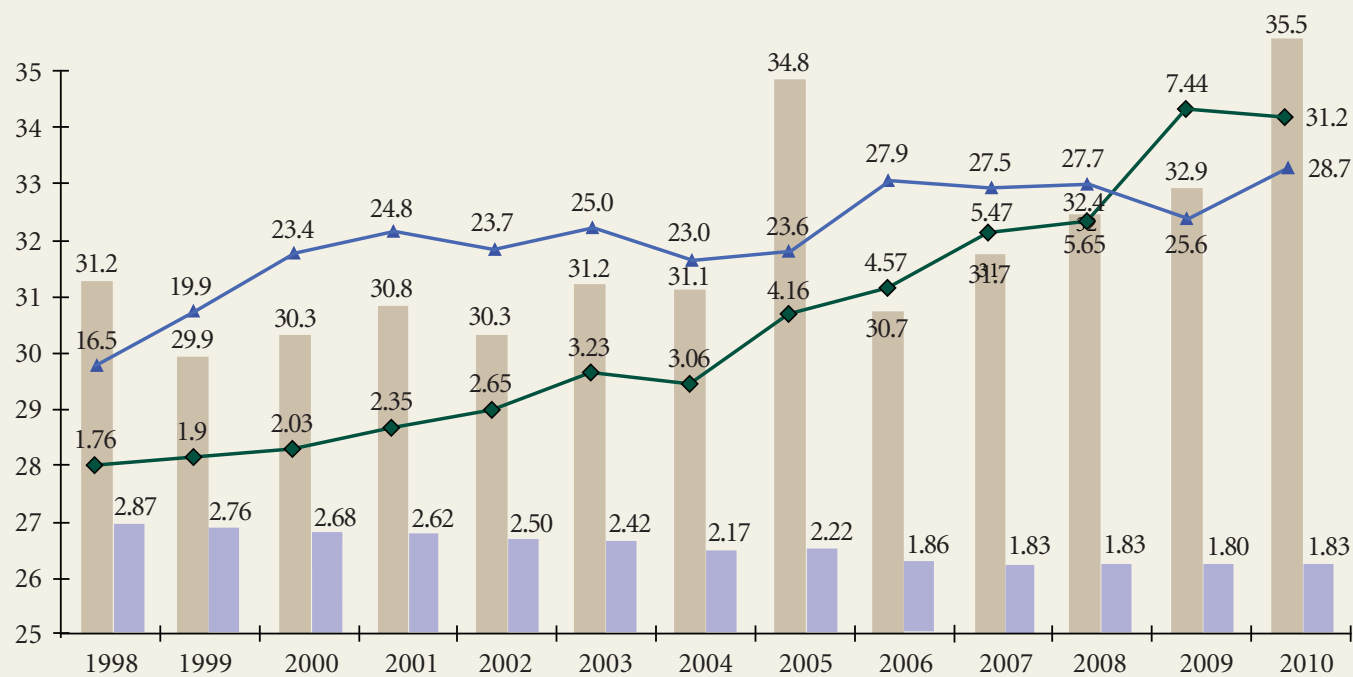

\footnotetext{
$\checkmark$ Ассигнования на гражданскую науку из средств федерального бюджета, в постоянных ценах 1991 г. (млн руб.)

_— Число патентных заявок на изобретения, поданных отечественными заявителями в России (mыc.)

—. Число публикаций российских авторов в научных журналах, индексируемых в базе данных Scopus (mыc.)

—_ Удельный вес России в общемировом числе публикаций в научных журналах, индексируемых в базе данных Scopus (\%)
}

технологического комплекса, который не может обеспечить требуемые объемы и качество предложения научно-технической продукции. Значительная часть наблюдаемых в России «инновационных» проблем имеют общесистемные корни и могут быть преодолены только в рамках комплексной программы мер. Курс на инновационную модель экономики в динамично меняющемся мире требует формирования долговременной стратегии, выработки приоритетов развития, особого внимания к новым постиндустриальным секторам, зачастую не связанным с традиционным пониманием промышленного роста.

\section{Переход к инновационной экономике - абсолютный императив развития России}

Переход к инновационной экономике является абсолютным императивом развития России до 2020 г. и в более отдаленной перспективе. По расчетам ИСИЭЗ НИУ ВШЭ, отказ от проведения активной политики в сфере науки и инноваций может привести к 2020 г. к кумулятивным потерям в размере 6.5\% ВВП (или более 7 трлн руб.). Поддержка новаторства и формирование эффективного инновационного комплекса необходимы как для повышения

\section{Рис. 5. Сфера науки и инноваций в России: утрата конкурентных позиций}

\section{Фундаментальная наука}

\section{Публикации в ведущих научных} журналах мира (2010)

Россия - 16-е место (1995 - 7-е место) Китай -2 -е место $(1995-14$-е место)
Цитируемость (Scopus, 2010)

Россия - 27-е место

Бразилия - 18-е место

Индия - 15-е место

Китай - 4-е место

\section{Прикладная наука и инновации}

$$
\begin{aligned}
& \text { Число «триадных» патентных семей (2009) } \\
& \text { Россия - 63(62) } \\
& \text { США - } 13715(1995-12241) \\
& \text { Китай - 667 (1995-21) } \\
& \text { Израиль - 339(1995-159) }
\end{aligned}
$$

Доля инновационных товаров, работ,
устуг, новыхдля рынка, в общем объеме
отруженной продукци
Россия - $0.8 \%(2010)$
Германия - $3.3 \%(2009)$
Великобритания - 2.0\% (2009)

\section{Экспорт технологий}

Россия - 0.6 млрд долл. (2010)

Венгрия - 2.7 млрд долл. (2009)

Финляндия - 9.1 млрд долл. (2009)

США - 89.1 млрд долл. (2009)

Доля на мировом рынке
высокотехнологичной продукции (2009)
Россия $-0.2 \%$
Гонконг $-8.94 \%$
Сингапур $-6.61 \%$
Корея $-5.27 \%$




\section{Проблемные области}

Качество экономического роста

Технологическая база

Уровень развития НИС

Отставание от стран-лидеров с точки зрения приоритетности сферы науки и инноваций в политике государства

Степень вовлечения общества в инновационный процесс

\section{Проблемы/задачи}

Необходимость изменения профиля экономики в пользу секторов с высокой добавленной стоимостью и современными технологиями

Необходимость модернизации экономики с целью интеграции в глобальные производственно-технологические цепочки, а также появления компаний, способных конкурировать на мировом рынке

Необходимость развития сетевых взаимосвязей, устранения фрагментации и сокращения «инновационных разрывов» (отраслевого, регионального, социального и т.п.)

Необходимость формирования инновационной политики нового поколения и усиления ее регулятивного потенциала

Необходимость развития инновационного мировоззрения, навыков и компетенций, а также преодоления изоляции социально уязвимых групп населения от инновационных технологий, продуктов и услуг конкурентоспособности российских товаров и услуг в условиях глобального рынка, так и для оперативных, комплексных и взаимоувязанных решений внутренних проблем, смягчения негативных факторов, ограничивающих потенциал роста экономики (табл. 1).

В процессе перехода к инновационной экономике государство неизбежно столкнется с серьезными ограничениями и вызовами. Основные из них возникают в силу неустойчивости позиций страны в глобальном пространстве. Как уже отмечалось, Россия остается, прежде всего, поставщиком ресурсов и рынком сбыта для других государств и глобальных компаний. Продукция с высокой добавленной стоимостью производится и экспортируется в незначительных масштабах. В объеме продукции обрабатывающих производств доля машин и оборудования составляет 5.4\%; электротехнического, электронного и оптического оборудования - 6\%; транспортных средств - 8\%; суммарная доля этих групп продукции в экспорте - примерно 13\%, а в импорте - более $43 \%$ [Россия в цифрах, 2010, с. 208].

Сложившаяся международная специализация страны - участие в глобальной кооперации преимущественно на нижних уровнях переделов - увеличивает риски «банкротства» национальной экономики (а как следствие, и социальной нестабильности) при возможном резком изменении мировой конъюнктуры и усложнении условий конкуренции. Обострению ситуации способствуют новые тренды - разворачивание современных научно-технологических направлений (альтернативная энергетика, персонифицированная медицина и фармацевтика, биотехнологии, новые материалы, экологически чистые технологии, высокотехнологичные услуги и др.) и связанных с ними рынков; интенсификация инноваций во всех секторах, включая низкотехнологичные, где наблюдается интенсивное проникновение новейших технологий и ускорение процессов обновления продуктовых линеек. Эти тренды часто имеют разрушающий эффект для развития традиционных рынков, на которых действует большинство отечественных предприятий.

Еще одна актуальная проблема - определенный контраст между формированием в развитых странах новых моделей социальной политики, ориентированной на стимулирование инициативы и предпринимательства, и отечественной практикой с акцентом на патернализм, «игнорирование» креативного класса, административные методы воздействия. В ситуации, когда в России по мировым меркам весьма значительна доля образованных граждан и относительно высок уровень ВВП на душу населения, социальное недоверие к инициативам государства может привести к ограничениям в «гибкости» инструментов стимулирования инноваций, а стремление власти к тому, чтобы обеспечить их широкое общественное одобрение, — к неизбежному «загру блению» реализуемых подходов.

Адекватный ответ на существующие внешние и внутренние вызовы возможен только на основе развития инновационной экономики в увязке с ее интеграцией в глобальные процессы. Вне инновационной модели речь может идти только о возврате к экономике закрытого типа (новый «железный занавес»). Серьезно рассматривать эту возможность нецелесообразно.

\section{Сценарии инновационного развития}

С учетом вероятных глобальных технологических изменений (начало новой технологической «волны» либо ее существенная задержка с фокусом на масштабном тиражировании улучшающих инноваций [Апокин, Белоусољ, 2009; Мишарин и др., 2011]) и возможных вариантов трансформации НИС можно предложить для рассмотрения три базовых сценария развития инновационных процессов (табл. 2).

Детализация сценариев проведена с учетом возможных развилок, описываемых сочетанием различных параметров политики и формирующих «коридор возможностей» - пространство выбора конкретных инструментов регулирования (табл. 3). На практике в те или иные периоды времени политика государства, представленная наборами различных мер, может приближаться к границам этого пространства, при этом реализация любого из крайних сценариев в «чистом» виде маловероятна (из-за высоких начальных и кумулятивных затрат для прогрессорского и очевидной нежелательности инерционного варианта) и, скорее всего, будет осуществляться на базе баланса указанных возможностей.

Основные различия между сценариями могут быть спроецированы на две оси: 


\begin{tabular}{|c|c|}
\hline Инновации & $\begin{array}{l}\text { Комплексная реформа: разработка и внедрение масштабных пакетов инструментов стиму- } \\
\text { лирования спроса на инновации и поддержки их предложения }\end{array}$ \\
\hline Наука & $\begin{array}{l}\text { Комплексная реформа в увязке с оценкой результативности научных организаций, диффе- } \\
\text { ренцированной по направлениям и видам ИиР, ориентация на поддержку лучших }\end{array}$ \\
\hline Институты & $\begin{array}{l}\text { Принципиальное улучшение институциональных условий: } \\
\text { • поддержка конкуренции (подавление рентных и коррупционных механизмов функцио- } \\
\text { нирования бизнеса; сокращение административных барьеров и др.) } \\
\text { - оптимизация налогового регулирования с целью развития инноваций и обеспечения } \\
\text { долгосрочного экономического роста } \\
\text { - развитие цивилизованного рынка интеллектуальной собственности } \\
\text { - радикальная реформа корпоративного права, реальная независимость судов, внедрение } \\
\text { прецедентного права }\end{array}$ \\
\hline \multicolumn{2}{|r|}{ Умеренный: постепенное наращивание потенциала инновационного развития } \\
\hline Инновации & $\begin{array}{l}\text { Привлечение в сферу инноваций внебюджетных средств (принуждение госкомпаний } \\
\text { к инновациям, «выдавливание» устаревших технологий и производств и др.); поддержка } \\
\text { креативного класса и общеэкономической среды; масштабная локализация инновационных } \\
\text { производств }\end{array}$ \\
\hline Наука & $\begin{array}{l}\text { Целевая поддержка лучших; опережающая поддержка вузовской науки; «кнут» для роста } \\
\text { расходов госкомпаний на ИиР; поддержка кооперации субъектов НИС }\end{array}$ \\
\hline Подготовка кадров & $\begin{array}{l}\text { Акцент на подготовку и переподготовку имеющегося корпуса инженеров, обновление } \\
\text { программ подготовки инженерных (сертифицированные инженеры) и исследовательских } \\
\text { кадров с привлечением зарубежных специалистов и успешных российских } \\
\text { предпринимателей }\end{array}$ \\
\hline Институты & $\begin{array}{l}\text { Постепенное развитие общеэкономической среды и инфраструктуры инновационной } \\
\text { деятельности }\end{array}$ \\
\hline \multicolumn{2}{|c|}{$\begin{array}{c}\text { Инерционный: сохранение сложившихся тенденций и практик в условиях медленного роста экономики, } \\
\text { ее сырьевой ориентации и зависимости от внешней конъюнктуры }\end{array}$} \\
\hline Инновации & $\begin{array}{l}\text { - Акцент на ситуационные решения и «мягкие» реформы } \\
\text { - Адаптация готовых технологий и производств }\end{array}$ \\
\hline Наука & Консервация базовых институтов, параллельное выращивание альтернативных структур \\
\hline Подготовка кадров & $\begin{array}{l}\text { Постепенная «перенастройка» программ подготовки профессиональных кадров } \\
\text { в соответствии с возникающими запросами экономики }\end{array}$ \\
\hline
\end{tabular}

- системные, институциональные меры поддержки, сетевая кооперация на всех уровнях vs. ручное управление, государственный «менеджмент» инновационного развития;

- масштабы возможной поддержки и стимулирования.
В табл. 4 рассмотрены риски и последствия для крайних - прогрессорского и инерционного сценариев. Появление различных «протестных» либо заинтересованных групп связано с вероятным сопротивлением либо поддержкой с их стороны при попытках перераспределения бюджетных ресурсов на

\section{Табл. з. "Коридор возможностей" для выбора инструментов инновационной политики}

\section{Инерционный сценарий}

- Поддержка отдельных технологических и инновационных проектов в рамках установленных тематических приоритетов

- Точечные решения верхнего уровня («ручное» управление)

- Жесткая иерархическая организация политики

- Универсальность инструментов

\section{Прогрессорский сценарий}

\section{Модель политики}

- Стимулирование массовых инноваций во всех секторах экономики

- Создание благоприятной среды для инновационных компаний, неблагоприятной - для неинновационных

- Развитие сетевой кооперации на всех уровнях

- Перераспределение полномочий государства в пользу регионов, институтов развития, бизнес-ассоциаций

- Дифференциация инструментов по секторам экономики и типам инноваторов

Рынки/отраслевые приоритеты

- Продолжение приоритетной поддержки традиционных секторов предыдущей технологической волны (авиастроение, атомная энергетика и др.)

- Приоритетная поддержка секторов новой технологической волны и выхода на растущие рынки (новый хайтек, сфера услуг, «зеленый» рост и др.)

- Содействие инновациям в низкотехнологичных секторах

- Содействие развитию нетехнологических инноваций Приоритеты/критерии

- Акцент на политических аргументах при принятии решений в сфере инноваций

- Тематические приоритеты

- Технологические и нетехнологические инновации для повышения экономической эффективности и извлечения инновационной ренты («инновации для бизнеса»)

- Социальные приоритеты - «инновации в интересах общества», инклюзивные инновации

- Функциональные приоритеты (инжиниринг, дизайн, трансфер технологий, сетевая кооперация, кластеры, подготовка кадров) 


\begin{tabular}{|c|c|c|}
\hline & Прогрессорский сценарий & Инерционный сценарий \\
\hline $\begin{array}{l}\text { Ожидаемые } \\
\text { позитивные } \\
\text { изменения }\end{array}$ & $\begin{array}{l}\text { - Возникновение благоприятной для инноваций среды } \\
\text { - Ликвидация барьеров развития } \\
\text { - Выход в новые высокотехнологичные ниши } \\
\text { • Приближение к передовому технологическому фронту } \\
\text { - Появление представительных групп инноваторов всех } \\
\text { типов (включая малый бизнес и компании - техноло- } \\
\text { гические лидеры) } \\
\text { • Повышение эффективности науки } \\
\text { - Повышение привлекательности сферы науки и иннова- } \\
\text { ций для молодежи и зарубежных специалистов } \\
\text { - Оздоровление НИС, конструирование экономики по- } \\
\text { стиндустриального типа } \\
\text { - Обеспечение устойчивости экономики }\end{array}$ & $\begin{array}{l}\text { - Поддержка и развитие важных сегментов эко- } \\
\text { номики, их технологическое перевооружение } \\
\text { - Рост масштабов и уровня развития вузовской } \\
\text { науки } \\
\text { - Создание точечных центров превосходства } \\
\text { - Рост качества подготовки кадров в ведущих } \\
\text { вузах } \\
\text { - Отсутствие краткосрочных социальных из- } \\
\text { держек }\end{array}$ \\
\hline $\begin{array}{l}\text { Вероятные не- } \\
\text { гативные по- } \\
\text { следствия }\end{array}$ & $\begin{array}{l}\text { - Отложенность результатов, отсутствие быстрых эф- } \\
\text { фектов } \\
\text { - Отказ от традиционных сфер компетенции } \\
\text { - Сохранение дисбалансов в торговле технологиями и } \\
\text { высокотехнологичной продукцией; акцент в кратко- } \\
\text { срочной перспективе на импорт технологий } \\
\text { - Вероятные социальные издержки }\end{array}$ & $\begin{array}{l}\text { - Сохранение низкого уровня инновационной } \\
\text { активности, «технологичности» экономики } \\
\text { - Невозможность сократить отставание от пе- } \\
\text { редового технологического фронта; усиление } \\
\text { зависимости от мировых лидеров в будущем } \\
\text { - Отток за рубеж новых технологий и квалифи- } \\
\text { цированных кадров, новых бизнесов } \\
\text { - Снижение результативности сектора ИиР } \\
\text { в целом } \\
\text { - Нарастание секторальной разбалансирован- } \\
\text { ности } \\
\text { - Специализация России на рынках «вчераш- } \\
\text { него дня», роль потребителя в глобальных } \\
\text { цепочках создания стоимости }\end{array}$ \\
\hline Риски & $\begin{array}{l}\text { - Сложность, масштабность, «цена» преобразований: } \\
\text { большое количество «обязательных» требований (кон- } \\
\text { курентная среда и др.), без выполнения которых разви- } \\
\text { тие по данному варианту маловероятно (в том числе к } \\
\text { комплексности и солласованности регулирования) } \\
\text { - Ухудшение позиций на традиционных рынках } \\
\text { - Риски «анклавной модернизации» } \\
\text { - Дефицит инвестиций (государственных и частных) } \\
\text { - Сужение фронта выполняемых ИиР } \\
\text { - Оппортунистическое поведение компаний (имитация } \\
\text { ИиР, акцент на импорте оборудования и технологий) } \\
\text { - Неопределенность статуса «невовлеченной» части об- } \\
\text { разованного населения и другие социальные риски } \\
\text { - Негативный PR, приводящий к отказу от реформ }\end{array}$ & $\begin{array}{l}\text { - Ошибочный выбор приоритетов } \\
\text { - Недостаток гибкости, замедленная реакция на } \\
\text { изменения } \\
\text { - Деформация экономики (крен в сторону от- } \\
\text { Дельных секторов за счет стагнации прочих) } \\
\text { - Блокирование и искажение решений на ниж- } \\
\text { них уровнях иерархии, их формальное вы- } \\
\text { полнение } \\
\text { - Непредсказуемость «правил игры» } \\
\text { - Деградация научного комплекса } \\
\text { - Излишний оптимизм в оценке возможностей } \\
\text { быстрого и эффективного развития вузов- } \\
\text { ской науки } \\
\text { Оппортунистическое поведение компаний } \\
\text { госсектора (имитация инновационной дея- } \\
\text { тельности) }\end{array}$ \\
\hline $\begin{array}{l}\text { Протестные } \\
\text { группы }\end{array}$ & $\begin{array}{l}\text { - Промышленное лобби (руководители ряда крупнейших } \\
\text { компаний и зависящих от них регионов) } \\
\text { - Отдельные группы государственной бюрократии, заин- } \\
\text { тересованные в сохранении статус-кво } \\
\text { - Адресаты целевой поддержки (отдельные группы ак- } \\
\text { торов, на которые уже распространяются специальные } \\
\text { меры/условия поддержки) } \\
\text { - Незаинтересованная часть научного сообщества, за- } \\
\text { трагиваемые реформами научные организации } \\
\text { - Менеджмент и акционеры некоторых компаний } \\
\text { - Консервативная (или плохо информированная) часть } \\
\text { населения }\end{array}$ & $\begin{array}{l}\text { - Представители новой экономики } \\
\text { - Население (компании не выполняют } \\
\text { социально-экономические запросы общества, } \\
\text { но расходуют ресурсы государства) } \\
\text { - Средний и малый бизнес } \\
\text { - Представители базовых секторов экономики } \\
\text { - Основная масса инноваторов } \\
\text { - Активная часть профессорско- } \\
\text { преподавательского состава, научного и биз- } \\
\text { нес - сообществ, молодые специалисты }\end{array}$ \\
\hline
\end{tabular}

цели модернизации экономики и инновационного роста. Для разных сценариев к протестным группам были отнесены, прежде всего, промышленное лобби, отдельные категории бюрократии, заинтересованные в сохранении статуса-кво, адресаты действующей государственной поддержки и незаинтересованная часть научного сообщества.

Предложения по мерам политики представлены для прогрессорского сценария.

Во-первых, по оценке экспертной группы, никакой другой сценарий не позволит отечественной экономике выйти из технологической «западни» ни к 2020 г., ни в более отделенной перспективе (с учетом остроты накопившихся проблем и масштабов отставания по всем индикаторам, характеризующим развитие инновационной сферы). Этот сценарий представляется наиболее сложным, но одновременно и наиболее перспективным в плане обеспечения долгосрочной конкурентоспособности страны. В нем ожидаются более масштабные мероприятия по «настройке» бизнес-среды, и наряду с государственным стимулированием будут активно задействованы механизмы рынка. Эффективность политики будет определяться здесь наличием конкурентных механизмов в зонах роста, развитие которых должно стать одним из основных условий государственной поддержки.

Во-вторых, по расчетам, расходы бюджета на инновационную деятельность по прогрессорскому варианту отличаются от инерционного менее чем на 10\% (экономия средств как итог проводимых реформ) при достижении существенно более высоких целевых параметров развития инновационной сферы (см. ниже).

В-третьих, ожидаемые бюджетные ограничения создают угрозу для реализации любого из 
рассматриваемых сценариев, поскольку повышают риски пропорционального сокращения расходов по всем направлениям инновационной политики, узкой трактовки ее содержания, акцента на ведомственные меры в ущерб межведомственным инструментам стимулирования и т. д. Высокая налоговая нагрузка на бизнес с целью сокращения бюджетного дефицита без ощутимого улучшения предпринимательского климата неизбежно приведет к снижению мотивации к инновациям для широкой совокупности хозяйствующих субъектов. В этих условиях реализация прогрессорского сценария (особенно в части смягчения административных барьеров, создания жестких ограничений для компаний, которые не намерены осуществлять внедренческую деятельность, модернизировать производство) может достаточно быстро актуализировать инновационные интересы бизнеса, содействовать притоку в эту сферу внебюджетных средств.

В-четвертых, разработка прогрессорского сценария позволяет предложить руководству страны целый комплекс инструментов регулирования. Отдельные наборы таких инструментов могут быть использованы и в рамках других сценариев.

\section{Принципы отбора инструментов регулирования}

Необходимо стимулировать не только предложение, но и спрос на инновации, развивать конкурентные механизмы.

Сегодня в России важно сформировать систему современных инструментов инновационной политики, гармонизированных с лучшей международной практикой, и создать условия для их применения. Наборы регуляторов, используемых в каждый период времени, особенно на начальном этапе, могут (а чаще всего должны) быть дифференцированы для разных хозяйствующих субъектов, секторов, а также различных типов фирм-инноваторов. Ожидается, что их имплементация будет способствовать переходу на более продвинутые инновационные режимы (от имитации и заимствования к созданию конкурентоспособных на российском и глобальном рынке продуктов и технологий), развитию инновационных умонастроений в обществе, инновационных навыков и компетенций работников [OECD, 2010b; European Commission, 2009].

Комплекс предлагаемых мер инновационной политики структурирован по направлениям, выделенным в табл. 2 и 3, следующим образом:

- поддержка массовых инноваций во всех секторах, включая низкотехнологичные (создание благоприятной среды для инновационных компаний и неблагоприятной - для неинновационных): стимулирование новаторства на предприятиях, усиление инновационной ориентации государственных закупок, поддержка малого инновационного бизнеса, регулирование заимствований технологий и производств;
- содействие инновационному развитию традиционных и формированию новых секторов экономики;

- усиление эффектов политики - повышение эффективности использования ресурсов, реализация функциональных приоритетов (компенсация провалов инновационного цикла), децентрализация политики в пользу регионов, институтов развития, бизнес-ассоциаций;

- повышение качества предложения инноваций рост результативности науки, ее эффективное финансирование, стимулирование инвестиций бизнеса в сектор ИиР;

- реализация социальных функций инноваций развитие человеческого капитала инновационной сферы, поддержка креативного класса, реализация программ интеграции уязвимых групп населения в инновационные процессы (инклюзивные инновации), улучшение общественного восприятия инноваций.

Перечень предлагаемых мер (с их распределением по срокам реализации) приведен в табл. 5. При обосновании конкретных мер учитывались следующие установки:

- фокус на инструментах, ориентированных на приоритетные изменения (например, для России принципиальное значение имеет стимулирование инвестиционной активности, низкий уровень которой является одним из болезненных ограничителей роста экономики);

- акцент на инструментах, поддерживающих функциональные приоритеты (компенсация провалов инновационного цикла);

- структурирование инструментов по типам и критериям эффективности, подтвержденным международным опытом;

- отбор инструментов с учетом целей основных субъектов инновационного процесса;

- учет специфики отраслевых или региональных инновационных комплексов и др.

\section{Обоснование выбора мер политики}

Поддержку инновационной активности следует направлять на сектора, которые способны к международной конкуренции и кооперации или уже участвуют в них.

Научно-технологический комплекс требуется реформировать в направлении большей интеграции с бизнесом и образованием.

Важно привлекать в Россию транснациональных игроков на рынке инноваций, развивать механизмы сетевых взаимодействий.

Низкий уровень спроса на инновации в России существенно ограничивает как потенциал инновационного роста, так и регулирующие возможности государства. Задачу его повышения целесообразно решать поэтапно (табл. 5). В начале роль «локомотива» развития должно сыграть государство, которое уже проявило себя активным игроком на 


\begin{tabular}{|c|c|c|c|c|}
\hline \multirow{2}{*}{$\begin{array}{l}\text { Направление } \\
\text { политики }\end{array}$} & \multirow[t]{2}{*}{ Предлагаемые меры } & \multicolumn{3}{|c|}{ Сроки реализации } \\
\hline & & 2012 & 2014 & 2020 \\
\hline \multicolumn{5}{|c|}{ Стимулирование массовых инноваций во всех секторах экономики } \\
\hline \multirow{8}{*}{$\begin{array}{l}\text { Стимулиро- } \\
\text { вание инно- } \\
\text { вационной } \\
\text { деятельности } \\
\text { предприятий }\end{array}$} & $\begin{array}{l}\text { Формирование комплексных налогового и таможенного режимов; систематиза- } \\
\text { ция налоговых льгот в инновационной сфере и совершенствование их админи- } \\
\text { стрирования }\end{array}$ & + & + & + \\
\hline & Предоставление льготного режима для инновационных стартапов & + & + & + \\
\hline & $\begin{array}{l}\text { Стимулирование экспорта инновационной продукции и услуг, а также предприя- } \\
\text { тий, участвующих в международной кооперации в инновационной сфере }\end{array}$ & + & + & + \\
\hline & $\begin{array}{l}\text { Субсидирование процентных ставок по кредитам компаний на инновационное } \\
\text { развитие (в том числе на техническое перевооружение), а также лизинговых пла- } \\
\text { тежей за современное технологическое оборудование }\end{array}$ & + & + & + \\
\hline & $\begin{array}{l}\text { Развитие механизмов «принуждения» компаний к инновациям (мониторинг } \\
\text { программ инновационного развития, введение инновационных технических } \\
\text { регламентов и стандартов; ужесточение экологических, ресурсосберегающих тре- } \\
\text { бований, требований к качеству и безопасности) }\end{array}$ & + & + & + \\
\hline & $\begin{array}{l}\text { Ускоренная амортизация нематериальных активов (при постановке их на учет по } \\
\text { рыночной стоимости) }\end{array}$ & - & + & + \\
\hline & $\begin{array}{l}\text { Введение в качестве обязательных разделов по инновациям в национальных, от- } \\
\text { раслевых и региональных стратегиях }\end{array}$ & + & + & + \\
\hline & $\begin{array}{l}\text { Введение в федеральных и региональных органах исполнительной власти, компа- } \\
\text { ниях с госучастием должности заместителя руководителя по инновациям; фор- } \\
\text { мирование из их числа национального совета с функцией экспертизы проектов } \\
\text { нормативных правовых актов на предмет оценки их влияния на инновационное } \\
\text { развитие }\end{array}$ & + & + & + \\
\hline \multirow{7}{*}{$\begin{array}{l}\text { Усиление } \\
\text { иннова- } \\
\text { ционной } \\
\text { ориентации } \\
\text { госзакупок }\end{array}$} & $\begin{array}{l}\text { Введение критерия инновационности в практику госзакупок; оценка их иннова- } \\
\text { ционного потенциала; внедрение сквозной системы госзакупок по всему иннова- } \\
\text { ционному циклу }\end{array}$ & + & + & + \\
\hline & Государственные закупки ИиР по направлениям, востребованным бизнесом & + & + & + \\
\hline & $\begin{array}{l}\text { Дифференциация режима госзакупок (новые способы размещения): конкурент- } \\
\text { ные переговоры, конкурсы с предквалификацией, контракты с отлагательным } \\
\text { условием }\end{array}$ & - & + & + \\
\hline & $\begin{array}{l}\text { Распространение практики каталитических госзакупок (государство инициирует, } \\
\text { использует бизнес) }\end{array}$ & - & + & + \\
\hline & $\begin{array}{l}\text { Разработка нормативной правовой базы для организации межведомственных } \\
\text { закупок инновационных решений; муниципальных закупок с инновационным } \\
\text { компонентом }\end{array}$ & - & + & + \\
\hline & Введение премии за инновации в цене закупки & - & - & + \\
\hline & Распространение практики кооперационных госзакупок & - & + & + \\
\hline \multirow{4}{*}{$\begin{array}{l}\text { Поддержка } \\
\text { малого инно- } \\
\text { вационного } \\
\text { бизнеса }\end{array}$} & Гранты для малых и средних инновационных предприятий & + & + & + \\
\hline & $\begin{array}{l}\text { Софинансирование расходов малых и средних предприятий на лизинг нового } \\
\text { технологического оборудования }\end{array}$ & - & + & + \\
\hline & Программы закупок для стимулирования инноваций в малом и среднем бизнесе & - & + & + \\
\hline & $\begin{array}{l}\text { Софинансирование расходов на получение и поддержку патентов за рубежом, } \\
\text { стандартизацию продукции, подготовку и/или привлечение квалифицированно- } \\
\text { го персонала }\end{array}$ & - & + & + \\
\hline \multirow{6}{*}{$\begin{array}{l}\text { Регулиро- } \\
\text { вание заим- } \\
\text { ствований } \\
\text { технологий/ } \\
\text { производств }\end{array}$} & $\begin{array}{l}\text { Создание запретительных барьеров для ввоза устаревших технологий (в том } \\
\text { числе по энергоэффективности, экологичности): таможенные пошлины, налоги, } \\
\text { штрафы и иные платежи }\end{array}$ & + & + & + \\
\hline & $\begin{array}{l}\text { Создание благоприятных условий для импорта новых для России технологий } \\
\text { (машин, оборудования, компонентов, прав на результаты интеллектуальной } \\
\text { деятельности): система поиска наилучших доступных технологий для приори- } \\
\text { тетных отраслей; администрирование, таможенный режим для беспошлинного } \\
\text { ввоза; государственные гарантии и налоговые льготы }\end{array}$ & + & + & + \\
\hline & $\begin{array}{l}\text { Обеспечение роста уровня локализации производств и расширения сети мест- } \\
\text { ных поставщиков }\end{array}$ & - & + & + \\
\hline & $\begin{array}{l}\text { Содействие иностранным компаниям в переносе в Россию исследовательских и } \\
\text { инжиниринговых центров, поиске квалифицированных местных поставщиков, } \\
\text { подготовке и рекрутинге кадров }\end{array}$ & + & + & + \\
\hline & $\begin{array}{l}\text { Пересмотр ограничений на допуск иностранных инвесторов в отрасли россий- } \\
\text { ской экономики и виды деятельности }\end{array}$ & - & + & + \\
\hline & $\begin{array}{l}\text { Разработка программы привлечения зарубежных «брендовых» технологических } \\
\text { инвесторов (упрощение процедур согласования и сокращение их сроков; предо- } \\
\text { ставление инфраструктуры и т. п.) }\end{array}$ & + & + & + \\
\hline
\end{tabular}


Содействие инновационному развитию традиционных и формированию новых секторов экономики

Приоритетная поддержка формирования новых секторов экономики и выхода на растущие рынки инно вационных товаров и услуг

Создание национальной экспертной сети по долгосрочному научнотехнологическому прогнозированию с участием широкого круга заинтересованных сторон (крупных компаний, ведущих вузов и НИИ, бизнес-ассоциаций, территорий инновационного развития)

Развитие долгосрочных программ субсидирования создания высокотехнологичных производств (в рамках кооперации предприятий с вузами и научными организациями) с отлагательными условиями пролонгации и обязательным требованием мониторинга их реализации

Развитие системы технологических платформ с участием широкого круга заинтересованных сторон (бизнеса, научных организаций, вузов и др.); формирование сети центров открытых инноваций

Введение критерия инновационности при оценке крупных инфраструктурных проектов (Инвестфонд, Внешэкономбанк и др.)

Поддержка закупок лучших технологий компаниями с государственным участием

Субсидирование и льготное налогообложение при реализации масштабных инвестиционных проектов инновационной направленности

Формирование и финансирование на принципах частно-государственного партнерства масштабных научно-технологических проектов общегосударственного значения

\section{Усиление эффектов инновационной политики}

Повышение эффективности использования ресурсов

\section{Функцио-} нальные приоритеты: компенсация провалов инновационного цикла
Децентрализация инновационной политики
Обязательный технологический аудит крупных инвестиционных/ инфраструктурных проектов и компаний с госучастием

Налоговое стимулирование закупок энергоэффективного оборудования, в том числе льготы по налогу на имущество

Дестимулирование устаревших производств (налоги, экологические платежи, санкции - вплоть до закрытия)

Разработка и внедрение технических регламентов и стандартов, стимулирующих отказ от использования устаревших технологий и оборудования; ужесточение экологических, ресурсосберегающих стандартов

Программы скрапирования морально и физически устаревшего оборудования

Развитие сети сервисных и образовательных центров в сфере инжиниринга, дизайна, прототипирования

Поддержка посреднических центров (на базе ведущих вузов и НИИ) в области трансфера технологий, маркетинга, научно-технической информации и оказания других услуг в инновационной сфере («технологические брокеры», «инновационные ассистенты»)

Введение механизмов инновационных ваучеров в целях организации действенной системы налогового стимулирования аутсорсинга услуг инновационного характера

Поддержка создания центров технического содействия развитию малых предприятий при вузах и НИИ

Создание общероссийской информационной базы инновационных продуктов и технологий, сети отраслевых центров научно-технической информации

Создание и развитие региональных технологических платформ

Субсидирование из федерального бюджета региональных программ поддержки инновационной деятельности

Поддержка территорий инновационного развития (Сколково, инновационноактивные регионы, особые экономические зоны, наукограды)

Проведение конкурсов инновационных предложений по решению социальных, инфраструктурных и экологических проблем на уровне городов и регионов

Тиражирование опыта успешных инновационно активных регионов и городов

Развитие саморегулируемых организаций в инновационной сфере и поддержка бизнес-ассоциаций (выработка стандартов, экспертиза, представление интересов участников и т. д.)

Программы информирования органов власти и госкомпаний о возможностях внедрения инноваций (интернет-портал, ведомственные экспертные советы, рабочие группы); демонстрация возможностей наиболее передовых технологических решений для их продвижения в крупных компаниях

\begin{tabular}{|c|c|c|}
\hline- & - & + \\
\hline- & - & + \\
\hline+ & + & + \\
\hline+ & + & + \\
\hline- & + & + \\
\hline- & - & + \\
\hline- & + & + \\
\hline
\end{tabular}

\begin{tabular}{|c|c|c|c|}
\hline+ & - & - \\
\hline+ & - & - \\
\hline+ & - & - \\
\hline+ & + & + \\
\hline- & + & + \\
\hline- & + & + \\
\hline- & + & + \\
\hline- & + & + \\
\hline- & + & + \\
\hline
\end{tabular}


Продолжение табл. 5

Направление

Предлагаемые меры

Сроки реализации

политики

$2012 \quad 2014$

Повышение качества предложения инноваций

Повышение

результативности

сектора ис-

следований и

разработок

Повышение эффективности финансирования науки

Стимулирование инвестиций бизнеса в сферу науки

Развитие обязательной системы оценки деятельности государственных организаций, выполняющих ИиР, на основе международно принятых подходов

Поддержка создания центров превосходства и программы выращивания конкурентоспособных научных коллективов на перспективных направлениях

Поддержка программ развития национальных исследовательских университетов

Сплошной технологический аудит отраслевых НИИ и КБ с госучастием; разработка и реализации программы оптимизации их сети

Программа развития доконкурентных ИиР в интересах реального сектора экономики (технологические платформы, кооперативные институты, центры открытых инноваций и т. п.)

Реализация комплекса мер по развитию инфраструктуры науки (проекты меганауки, центры коллективного пользования, центры научно-технической информации и прогнозирования на базе ведущих вузов и НИИ, лизинг научного оборудования)

Введение единого раздела по расходам на гражданскую науку в бюджетную классификацию и организация их мониторинга

Формирование единой национальной программы фундаментальных исследовании, открытой для всех участников на конкурсной основе

Развитие и масштабирование деятельности государственных фондов поддержки науки; повышение их доли в расходах бюджета на гражданскую науку до $10 \%$ (2012), 15\% (2015), 20\% (2020)

Модернизация системы внебюджетных фондов ИиР

Введение обязательного технологического аудита ИиР компаний с госучастием на регулярной основе

Ревизия налоговых льгот в сфере науки, их систематизация и масштабирование

Софинансирование расходов бизнеса в рамках кооперации с научными организациями и вузами

Снятие административных барьеров для международной кооперации в сфере науки (таможенное регулирование, валютный контроль и т. п.)

Формирование эффективного режима прав на результаты интеллектуальной деятельности

\section{Реализация социальных функций инноваций}

\section{Развитие} человеческого капитала инновационной сферы

Поддержка креативного класса

Реализация программ интеграции социально уязвимых групп населения в инновационные процессы (инклюзивные инновации)

Улучшение восприятия инноваций обществом
Программы развития научно-технического творчества и инновационного предпринимательства молодежи

Программы дополнительного образования школьников, в том числе по развитию естественнонаучных знаний

Поддержка стажировок молодых исследователей, инженеров, преподавателей в ведущих зарубежных центрах и компаниях

Программы обмена опытом в области инновационного предпринимательства с ведущими странами (стажировки руководителей и специалистов инновационных фирм, мастер-классы ведущих зарубежных специалистов)

Программы поддержки креативного класса и массового малого инновационного бизнеса, реализующего технологические и нетехнологические инновации (адресные гранты; развитие механизмов микрофинансирования; центры информационной поддержки и технического содействия; тематические форумы и конференции для развития партнерских связей и др.)

Программы поддержки реэкспорта компетенций и бизнесов для развития инновационных компаний - глобальных игроков

Выявление и поддержка «продвижения» талантливых детей

Внедрение современных стандартов оказания инновационных услуг в социальной сфере (телемедицина, дистанционное образование, информатизация органов социальной защиты и обслуживания населения; адаптация государственных услуг, предоставляемых онлайн, к потребностям уязвимых групп граждан и т. д.) и государственном управлении, повышение качества и доступности таких услуг; поддержка мер по обеспечению доступа социально уязвимых групп населения к инновационным технологиям, продуктам и услугам

Субсидирование распространения широкополосного Интернета и недорогой мобильной связи в удаленных регионах

Развитие сети центров коллективного интернет-доступа, в том числе для уязвимых групп населения

Реализация доступных программ по повышению компьютерной грамотности и развитию языковых навыков населения

Старт программы популяризации научной и инновационной деятельности (продвижение «историй успеха» и т. д.)

Содействие созданию некоммерческих организаций, способствующих вовлечению населения в инновационные процессы, распространению информации об инновационной деятельности и др.

\begin{tabular}{|c|c|c|}
\hline - & + & + \\
\hline- & + & + \\
\hline+ & + & + \\
\hline- & + & + \\
\hline+ & + & + \\
\hline+ & + & + \\
\hline+ & + & - \\
\hline- & + & + \\
\hline+ & + & + \\
\hline - & + & - \\
\hline - & + & - \\
\hline+ & + & + \\
\hline+ & + & - \\
\hline+ & - & - \\
\hline+ & + & + \\
\hline
\end{tabular}


инновационном «поле» (поддержка кооперации вузов и бизнеса, инновационной инфраструктуры вузов; создание технологических платформ; разработка программ инновационного развития компаний с государственным участием и др.).

Предлагается систематизировать уже реализуемые меры, придать им согласованный и комплексный характер. В условиях сложившихся бюджетных ограничений запуск новых инициатив, связанных с дополнительными финансовыми обязательствами государства, в краткосрочной перспективе лимитирован. Поэтому в 2012-2014 гг. важно консолидировать имеющиеся инструменты, задействовать потенциал их совместного использования, добиться, чтобы каждая из существующих схем заработала с полной отдачей, стимулируя появление модельных инновационных бизнесов, опыт которых можно было бы тиражировать в дальнейшем.

В качестве центрального звена приложения усилий государства на этом этапе выбраны экспортные, таможенные и особенно налоговые льготы и преференции. Такие регуляторы являются действенным способом привлечения международных инвесторов и повышения конкурентоспособности инновационного комплекса, а также ослабления факторов, препятствующих инновациям.

Формирование специальных режимов косвенного, в том числе налогового, регулирования позволяет заинтересовать бизнес в повышении инвестиционной активности в сфере создания и реализации научно технологических достижений. Действующая система требует полной ревизии, систематизации и масштабирования. В итоге должен быть обеспечен комплексный налоговый и таможенный режим, направленный на стимулирование инновационной деятельности предприятий.

В России применяются примерно 15 видов налоговых льгот, которые формально относятся к категории стимулов для инновационной деятельности. Однако реальные масштабы налогового стимулирования невысоки. Большая часть льгот приходится на сокращение налогооблагаемой базы по имуществу, безвозмездно передаваемому образовательным учреждениям, а также по расходам на капитальные вложения (достройка, дооборудование, реконструкция, модернизация, перевооружение, частичная ликвидация основных средств). По данным Федеральной налоговой службы, объем предоставленных льгот по налогу на прибыль в сфере науки и инноваций составил малозаметную в масштабах отечественной экономики сумму в размере 160 млн руб. (2010 г.).

Применение налоговых стимулов оправдано в тех случаях, когда снижение налоговых поступлений в бюджет компенсируется масштабами ожидаемого инновационного роста. Страны, где практика интенсивного налогового стимулирования инноваций только вводится, демонстрируют высокий уровень отдачи от их внедрения (что сегодня крайне важно для России). В определенный момент возникает критическая масса инновационно-активных компаний либо критическая структура инновационных секторов, после чего дальнейшее интенсивное применение налоговых стимулов становится менее рациональным и они подлежат замене на более умеренные (поддерживающие) меры. Подобные решения в последние годы были приняты правительствами Канады, Японии, Кореи, Бельгии и других стран. В любом случае реактивность предпринимательской среды определяет потребность в эффективных инструментах обратной связи (мониторингах, экономико-статистических измерениях), позволяющих спланировать на ограниченный промежуток времени эффективную систему стимулов (масштабы, комбинирование инструментов, адресное регулирование) [Therrien, 2010].

Эффективным и экономически обоснованным направлением поддержки инноваций на первом этапе должно стать стимулирование международной кооперации компаний, в том числе деятельности экспортеров несырьевой продукции, в целях усиления их конкурентоспособности. Оказываемая таким фирмам поддержка в различных формах может быть увязана с рыночными механизмами контроля: критерием продолжения поддержки должно быть увеличение объема поставок на внешний рынок.

Важно активнее развивать и различные формы софинансирования - предоставление льгот и субсидий при условии финансирования разработок со стороны бизнеса.

В 2015-2020 гг. должна быть усилена роль государства как модератора сетевых взаимодействий, инициатора частно-государственных партнерств (в частности, на базе технологических платформ). Это обеспечит переход к «массовизации» инноваций, стимулирует создание новых рынков в опережающем режиме, что позволит отечественным производителям выступать на них в роли пионеров при условии разделения рисков между бизнесом и органами власти. Ключевые меры на этой стадии связаны с развитием сервисных и образовательных центров инжиниринга, прототипирования и дизайна, других каналов создания и трансфера инновационной продукции (услуг); поддержкой инновационной инфраструктуры; созданием прозрачных и непротиворечивых правил взаимодействия инновационных акторов; смягчением финансовых и отчасти коммерческих рисков.

Особого внимания потребуют институт государственного заказа (расширение портфеля заказов на основе предложений бизнеса, закупок продукции инновационных фирм и др.); механизмы принуждения к инновациям компаний с государственным участием; меры по информированию и обучению потребителей, формированию спроса на нетехнологические инновации, стимулированию потребления инновационной продукции средним и малым бизнесом.

Существенное значение для стимулирования инноваций имеет секторальная дифференциация регулирующих мер. Россия до сих пор ориентируется прежде всего на поддержку традиционных высокотехнологичных отраслей (феномен «высокотехнологичной близорукости», определенный экспертами ОЭСР [OECD, 2008; OECD, 2011]). В глазах большой части общества это делает инновации специфическим, сугубо технологическим явлением, что заведомо ограничивает пространство выбора конкретных 


\section{Табл. 6. Отраслевая дифференциация инновационной политики}

\begin{tabular}{|c|c|c|}
\hline Задачи & Акценты регулирования & Примеры секторов \\
\hline $\begin{array}{l}\text { Традиционные высокотехноло- } \\
\text { гичные сектора: повышение кон-- } \\
\text { курентоспособности и экспортно- } \\
\text { го потенциала }\end{array}$ & $\begin{array}{l}\text { Разработка и внедрение пере- } \\
\text { довых технологий, поддержка } \\
\text { ИиР, высокотехнологичного } \\
\text { экспорта }\end{array}$ & $\begin{array}{l}\text { Авиастроение, космический и оборонно- } \\
\text { промышленный комплекс, атомная энергетика }\end{array}$ \\
\hline $\begin{array}{l}\text { Новые сектора: формирование } \\
\text { новых рынков высокотехнологич- } \\
\text { ной продукции и услуг, разработка } \\
\text { технологий для модернизации } \\
\text { производств }\end{array}$ & $\begin{array}{l}\text { Разработка прорывных техно- } \\
\text { логий, междисциплинарные } \\
\text { исследования, новые инстру- } \\
\text { менты регулирования (в том } \\
\text { числе технические регламенты } \\
\text { и стандарты), стимулирование } \\
\text { спроса }\end{array}$ & $\begin{array}{l}\text { Наноиндустрия, биотехнологии, медицинская } \\
\text { техника, электротехника, приборостроение }\end{array}$ \\
\hline $\begin{array}{l}\text { Сектора с преимущественно гори- } \\
\text { зонтальной организацией: дина- } \\
\text { мичная модернизация }\end{array}$ & $\begin{array}{l}\text { Адаптация и распространение } \\
\text { отдельных современных тех- } \\
\text { нологий, совершенствование } \\
\text { отраслевого регулирования, } \\
\text { инжиниринговые услуги, под- } \\
\text { держка импорта технологий и } \\
\text { компетенций }\end{array}$ & $\begin{array}{l}\text { Бытовая медицинская техника, медицинские } \\
\text { услуги, информационные услуги государства } \\
\text { для населения, энергоснабжение в небольших } \\
\text { городах и поселках, малая распределенная энер- } \\
\text { гетика, легкая промышленность, агропромыш- } \\
\text { ленный комплекс, лесное хозяйство, плантаци- } \\
\text { онные посадки, строительство и производство } \\
\text { стройматериалов, градостроительство }\end{array}$ \\
\hline $\begin{array}{l}\text { Общественный и инфраструктур- } \\
\text { ный сектора: технологическая мо- } \\
\text { дернизация, расширение спектра } \\
\text { высококачественных инновацион- } \\
\text { ных общественных услуг }\end{array}$ & $\begin{array}{l}\text { Разработка собственных техно- } \\
\text { логий, внедрение зарубежных } \\
\text { достижений, закупки для госу- } \\
\text { дарственных нужд }\end{array}$ & $\begin{array}{l}\text { Электронное правительство, медицинские и об- } \\
\text { разовательные услуги, дорожное строительство, } \\
\text { транспортные услуги }\end{array}$ \\
\hline $\begin{array}{l}\text { Сырьевые сектора: повышение } \\
\text { производительности, экологич- } \\
\text { ности, снижение энергоемкости, } \\
\text { расширение переделов }\end{array}$ & $\begin{array}{l}\text { Внедрение лучших доступных } \\
\text { технологий, техническое ре-- } \\
\text { гулирование, экологические } \\
\text { стандарты }\end{array}$ & $\begin{array}{l}\text { Нефтегазовый сектор, угольная промышлен- } \\
\text { ность, металлургия, лесопромышленный ком- } \\
\text { плекс }\end{array}$ \\
\hline
\end{tabular}

решений. Более предпочтительной является установка на распространение инноваций во всех секторах (высоко-, средне- и низкотехнологичных). Именно в последних двух сегментах может быть достигнут наиболее масштабный эффект от их распространения, охватывающий всю экономику и широкие слои общества. Варианты мер по регулированию инновационной активности в различных секторах экономики предложены в табл. 6.

Развитие инноваций в России тормозит сохранение зон, где использование устаревших технологий и низкооплачиваемого труда экономически привлекательно для компаний. Необходима последовательная политика вытеснения таких очагов «консервативной отсталости», включающая разработку дорожных карт повышения ресурсной, кадровой, экологической устойчивости экономики, современных технологических стандартов, регламентов с использованием ИКТ.

По оценкам экспертов, до 2020 г. трудно рассчитывать на серьезные сдвиги в «экологичности» и ресурсоемкости важнейших экспортоориентированных секторов отечественной экономики (металлургия, химия, нефтегазовая промышленность и др.) из-за высокой международной конкуренции за капитал. Компании могут легко уйти в страны третьего мира. В этих условиях в первую очередь целесообразно ужесточить требования в таких секторах, как жилищнокоммунальное хозяйство, строительство, энергетика. Важна также модернизация машиностроения и легкой промышленности, где изменение стандартов совпадает с обновлением производственного аппарата на базе импорта. В зонах монополизации или зарегулированности рынков целесообразны меры прямого регулирования (энергетика, транспорт, все вертикально интегрированные структуры); в зонах, более свободных для конкуренции, - рычаги косвенного воздействия.
Наконец, одним из базовых в повестке государственной политики должен стать вопрос оптимального сочетания инструментов стимулирования спроса на инновационную продукцию и на инновационные компании. Для этого в предлагаемый портфель мер включены регуляторы, нацеленные как на продукцию (административные рычаги, госзакупки, технологический аудит и др.), так и на ее разработчиков (повышение качества менеджмента, тиражирование лучших практик, развитие институциональной среды).

Регуляторы, ориентированные на повышение качества предложения инноваций, объединены в несколько блоков (табл. 5). Прежде всего, это система мер по повышению эффективности национальной науки для обеспечения роста масштабов и качества генерируемых ею результатов. Вместе с тем актуально развитие и других источников нововведений - изобретательства и рационализации на базе производственного опыта (на предприятиях), импорта и адаптации технологий, локализации инновационных производств. Причем все эти источники должны все в большей мере конкурировать друг с другом. Диапазон, акценты и выбор конкретных мер, обеспечивающих рост предложения инноваций, во многом предопределены спецификой отечественной науки (принадлежность большей части организаций и ресурсов к государственному сектору; квазигосударственная природа корпоративной науки, представленной преимущественно научными подразделениями крупных компаний с государственным участием; недостаточный, по мировым меркам, уровень развития университетских ИиР).

Исходя из интересов обеспечения долгосрочного устойчивого роста экономики и благосостояния общества, повышения качества человеческого капитала, укрепления национальной безопасности опережающее развитие собственного научного и 
технологического потенциала страны представляется магистральным направлением инновационной политики. Только на этой основе возможно достижение восприимчивости экономики к передовым технологиям, инновационным продуктам и услугам и, в конечном счете, ее реальной, устойчивой конкурентоспособности.

В краткосрочной перспективе центральным звеном комплексной реформы сектора ИиР станут меры по выявлению лучших организаций и исследовательских групп (лабораторий, отделов и т. п.); целевой поддержке их развития и кооперации; проведению институциональных преобразований, в том числе санации сети научных организаций на основе международно-признанных методов оценки их результативности, дифференцированных по направлениям и видам ИиР. Предлагается особое внимание уделить стимулам развития исследовательского и инновационного потенциала вузов, что будет способствовать становлению новой институциональной структуры сферы ИиР (в том числе, в сегменте прикладной науки взамен прекративших свое существование во многих секторах отраслевых НИИ, КБ и проектных организаций); гармонизации с практикой ведущих стран модели развития профессионального образования как непрерывного процесса, интегрированного с исследованиями, технологической и инновационной деятельностью.

В 2015-2020 гг. акцент рекомендуется перенести на опережающее развитие конкурентоспособных на мировой арене направлений фундаментальных и поисковых исследований, современных форм организации ИиР, инфраструктуры науки на прорывных направлениях и международного сотрудничества в этой сфере. Большое значение приобретет повышение эффективности использования государственной собственности и бюджетных средств; развитие кооперации (в том числе сетевой) хозяйствующих субъектов при осуществлении научной, образовательной и инновационной деятельности; эффективная комбинация «кнута» и «пряника» для роста масштабов и уровня ИиР в предпринимательском секторе экономики.

С учетом в целом низкого технологического уровня отечественной экономики и давления бюджетных ограничений важно также сфокусировать усилия на совериенствовании регулирования заимствования технологий и производсmb. По понятным причинам адаптационная модель представляется наиболее надежной и адекватной для большинства компаний (в особенности тех, которые не имеют собственной исследовательской базы), позволяя им реализовать стратегические преимущества «идущего сзади». Однако она имеет и очевидные недостатки, продуцируя риски навсегда остаться во «втором эшелоне» мирового научно-технологического прогресса.

Основные действия, которые может предпринять государство для поддержки адаптационных усилий компаний, заключаются в следующих мерах:
- поощрении их участия в международной кооперации на уровне производства современных узлов, сборки и др.;

- устранении барьеров, препятствующих импорту новых для России технологий (машин, оборудования, компонентов, прав на результаты интеллектуальной деятельности) - упрощение таможенных процедур, изменение тарифов, поддержка инкрементальной доработки (по примеру Китая);

- стимулировании модернизации (замены) основных фондов, высокий уровень износа которых препятствует повышению производительности, обеспечению конкурентоспособности продукции и устойчивому росту производства;

- применении санкций (вплоть до закрытия) к предприятиям, сохраняющим устаревшие производства;

- поддержке предприятий, занимающихся закупкой нового оборудования и его обслуживанием, полной заменой изношенных производственных линий (а не модернизацией отдельных элементов), а также обучением персонала для работы с этим оборудованием.

Очевидно, что эффективные заимствования на предприятиях не могут вестись без серьезных изменений в структуре управления. Здесь функции государства могут заключаться в распространении передовых управленческих практик, включая кадровую политику и гарантии социальной защиты персонала²

В долгосрочной перспективе предстоит добиться разумного баланса в стимулировании трансфера зарубежных технологий и развития собственного технологического потенциала (в том числе, через содействие кооперации отечественных компаний с отечественными же научными организациями и вузами).

Как уже отмечалось, для России важнейшим вызовом является ее низкая конкурентоспособность как глобального игрока, создающая известную асимметрию в потоках капиталов, продукции, технологий, трудовых ресурсов. В этих условиях целесообразно активизировать усилия по привлечению 6 страну транснациональных (а также крупных иностранных) высокотехнологичных компаний и технологических инвесторов с целью масштабной модернизации экономики, создания современных производств (в режиме полной сборки), исследовательских и инжиниринговых центров. Причем речь идет об их размещении не только на имеющихся либо создаваемых площадках (в иннограде Сколково, наукоградах, технико-внедренческих зонах, региональных кластерах), но и на неосвоенных российскими и зарубежными компаниями пространствах, а также о формировании на этой основе зон прямой включенности в глобальные рынки.

Возможные риски здесь очевидны и могут быть оценены на опыте быстро развивающихся государств (например, Китая, стран Юго-Восточной Азии). Зарубежные практики одновременно демонстрируют и пути снижения таких рисков: адресность (для 
привлечения инвесторов выбираются конкретные сектора, территории, площадки); обязательное создание партнерств с национальными фирмами; равноправное распределение прав на ноу-хау, другие объекты интеллектуальной собственности; ориентация на реальную (а не виртуальную) локализацию. Только в этом случае привлечение иностранных фирм будет содействовать развитию собственных высокотехнологичных производств и (с временным лагом) замещению импорта аналогичной продукцией, произведенной на территории страны.

Рекомендуемые механизмы привлечения зарубежных компаний включают: целевые льготы для «брендовых» технологических инвесторов, обеспечивающих демонстрационный эффект; смягчение ограничений по доступу иностранных инвесторов в те или иные сектора (виды деятельности), участию в капитале российских компаний; «мягкое» принуждение (поощрение) к переносу научно-технологических и образовательных компетенций в Россию; сокращение сроков выдачи разрешительной документации; оперативное предоставление на льготных условиях земельных участков, производственных помещений, других площадок; подключение к инфраструктуре; расширение практики офсетных сделок ${ }^{3}$; поддержка разработки и реализации региональных программ, предусматривающих привлечение зарубежных инвестиций и высокотехнологичных компаний.

Реализация новой модели инновационной политики предполагает поиск адекватных подходов к решению проблем создания и правовой защзиты прав на объекты интеллектуальной собственности.

В России рынок интеллектуальной собственности лишь складывается, поэтому скорость вовлечения научно-технических результатов в экономический оборот невысока. Характерной особенностью отечественной НИС является оторванность процесса разработки новых технологий от реальных потребностей производства и сферы услуг. Интеллектуальная собственность чаще всего создается не для конкретного потребителя и потому остается невостребованной со стороны производства и рынка. Между тем именно в процессе коммерциализации проявляются ее реальные конкурентные преимущества, а охраноспособные изобретения и ноу-хау становятся весомыми источниками доходов.

Как показано на рис. 5, в России число патентных заявок на изобретения достигает примерно 26 тыс. (8-е место в мире), однако 70\% из них содержат лишь незначительные усовершенствования техники и технологий. Изобретательская деятельность замкнута на внутренний рынок: удельный вес экспорта не превышает $13 \%$ от всего объема передачи технологий. Доля России в числе патентов, которые регистрируются в Европе и США - всего 0.1\%. Поступления от экспорта технологий имеют только 7\% организаций, выполняющих ИиР (в том числе от экспорта - $2.5 \%$ ).

В настоящее время Россия стоит перед выбором - оставаться страной низких инновационных возможностей и соответственно серьезных рисков для экономики либо сосредоточить усилия на повышении технического уровня и качества создаваемых технологий, их коммерциализации и использования. В этой связи важно усилить внимание к регламентации рынка охраняемой промышленной собственности (патентов, полезных моделей, в том числе созданных с привлечением бюджетных средств, ноухау), трансфера результатов интеллектуальной деятельности в производство и сферу услуг.

В кратко- и среднесрочной перспективе необходимы глубокий инфорсмент законодательства в области интеллектуальной собственности и амнистия интеллектуальной собственности (передача прав разработчикам научно-технических результатов), созданной за счет бюджетных средств. Значительные экономические возможности, которые открывает выход на зарубежные рынки знаний и технологий, делают актуальными такие меры, как льготные патентные пошлины, создание и развитие специальных фондов содействия патентованию, рост масштабов бесплатных консультационных и информационных услуг.

Для развития рынка интеллектуальной собственности предлагается последовательно улучшать условия капитализации ИиР, в том числе через постановку объектов интеллектуальной собственности на баланс компаний (бухгалтерский учет). Это особенно актуально для предприятий малого и среднего бизнеса, поскольку подобные действия служат основанием для увеличения балансовой стоимости предприятий, привлечения инвестиций, а исключительные права могут использоваться в качестве залога для получения кредитов.

Создание системы эффективного управления интеллектуальной собственностью подразумевает развитие объектов инфраструктуры, занимающихся продвижением технологий на рынки (патентные и маркетинговые отделы компаний, научных организаций и вузов; центры трансфера технологий; консалтинговые и инжиниринговые фирмы и пр.); расширение сети центров, оказывающих широкий спектр информационно-консультационных и экспертных услуг (патентные исследования с предоставлением скидок малому бизнесу, помощь в организации участия в международных выставках, оплата пошлин при регистрации и правовой охране и др.).

В долгосрочной перспективе предстоит добиться ощутимого повышения уровня защиты интеллектуальных прав (развитие патентных судов, обеспечение качества рассмотрения патентных исков) и улучшения качества профессиональной подготовки специалистов, владеющих необходимыми компетенциями (введение в учебные планы по техническим и естественнонаучным специальностям дисциплин, связанных с интеллектуальной собственностью и трансфером технологий; переподготовка патентных поверенных, маркетологов, аудиторов). Важным условием активизации рынка интеллектуальной собственности может стать развитие института ее оценщиков. По причине фактического отсутствия таких кадров, сложности и ресурсоемкости требуемых мер 
формирование этого института целесообразно проводить поэтапно.

\section{Кадры инновационной экономики, социальные инновации, креативный класс}

Актуальны институциональные меры, направленные на поддержку креативного класса, в том числе в целях предотвращения дальнейшей «утечки умов»; реализацию социальных функций инноваций; повышение степени вовлеченности общества в инновационный процесс.

Старение корпуса квалифицированных кадров (ученых, инженеров, преподавателей и др.), падение престижа инженерных и естественнонаучных специальностей, с одной стороны, и неразвитость предпринимательской культуры и практик подготовки менеджеров для инновационной сферы - с другой, создают очень узкий коридор возможностей для ка дрового маневра при переходе экономики на иннова циионную траекторию. И это справедливо для всех рассматриваемых сценариев. Восполнить имеющийся дефицит можно за счет трех основных источников зарубежных специалистов; российских специалистов, прошедших переквалификацию; вновь подготовлен ных кадров следующих поколений. Однако рассчи тывать на ощутимые последствия их использования можно, скорее всего, только в долгосрочной перспективе (после 2020 г.).
В первом случае потребуется серьезная модификация миграционного законодательства; создание достаточного количества привлекательных и высокооплачиваемых позиций в разных секторах (изменение ситуации, когда «уезжают ученые, а приезжают дворники»). До 2020 г. речь может идти о «точечных» проектах, например, по привлечению представителей российской научной диаспоры или отдельных зарубежных специалистов. Использование второго канала связано с внедрением модели «обучения в течение жизни», ощутимым улучшением и расширением программ дополнительного образования. Вряд ли удастся быстро задействовать и третий источник, но без него об устойчивом и долгосрочном инноваци онном развитии не может быть и речи. Работа с ним потребует «тектонических» подвижек в сфере образования и культуры. Некоторые возможные меры (вне повестки инновационной политики) по использованию названных источников развития кадров для инновационной экономики приведены в табл. 7.

C учетом временного горизонта Стратегии социально-экономического развития акцент в данном блоке сделан на мерах по развитию научно-технического и инновационного предпринимательства молодежи, программ стажировок молодых исследователей, преподавателей, инженеров и предпринимателей в ведущих зарубежных центрах и компаниях.

Социальная ориентированность инноваций на повышение качества жизни и расширение возможностей граждан обусловливает новые приоритеты

\section{Табл. 7. Усиление инновационной ориентации государственного регулирования в целом} ("заказ" на меры иных направлений политики)

Область регулирования
Возможные меры

\section{Поддержка конкуренции}

Снятие межрегиональных барьеров

Обеспечение условий для равноправной конкуренции с дешевой импортной продукцией

Усиление конкуренции при закупках товаров и услуг для государственных нужд и нужд компаний с государственным участием

Обеспечение конкурентной среды

Целесообразно: госзаказа на следующий год;
Активизация деятельности ФАС по снятию искусственной сегментации рынков границами регионов, подавляющей стимулы к инновациям (за исключением конкуренции с импортом)

Изменение тарифов (поэтапное снижение тарифных барьеров)

Действующее законодательство о государственных закупках в принципе подразумевает рост конкуренции, однако нормой остаются массовые нарушения закупочной процедуры

- более активное использование механизмов банковской гарантии возврата аванса и уплаты неустойки для допуска к торгам или на конкурс;

- удлинение планирования закупок и введение реальной возможности переноса средств

- создание системы прозрачных и конкурентных закупок в госкомпаниях

Обеспечение нормальной доходности проектов, дающих сверхприбыль (изъятие части ресурсной ренты); подавление рентных и коррупционных механизмов функционирования бизнеса

Качественное удорожание квалифицированной рабочей силы (в 1.5-2 раза), включая увеличение зарплаты бюджетников; последовательное повышение порога использования малоквалифицированного низкооплачиваемого труда

Последовательное повышение порога функционирования производств, отличающихся неблагоприятными последствиями для здоровья работников, окружающей среды и др.

Введение обязательной процедуры проверки проектов нормативных правовых актов на наличие ограничивающих конкуренцию норм

Мониторинг бизнес-ассоциациями (отраслевыми и региональными) решений муниципальных и региональных властей, компаний на предмет появления ограничивающих условий для конкуренции; оценка барьеров входа на отдельные рынки, в том числе обусловленных политикой крупных компаний

Введение практики антидемпинговых расследований для защиты интересов отечественных производителей от недобросовестной конкуренции со стороны зарубежных компаний 


\section{Развитие институтов в интересах перехода к инновационному росту}

Модернизация взаимодействия государства и бизнеса
Новые формы привлечения частного капитала к реализации научно-технологических программ (Форсайт-проекты, технологические платформы); формирование приоритетов технологического развития на базе подобных институтов; поддержка небольшого числа проектов с замещением - по мере продвижения к созданию конечных образцов - государственного финансирования частным

Создание малых и средних технологических компаний, стартапов, в том числе ориентированных на удовлетворение спроса крупных корпораций («американская» модель)

Усиление ответственности менеджеров и собственников (в случае получения компаниями государственной поддержки) за сокрытие прибыли, необоснованный отказ от инвестиций, вывод активов за рубеж

Проектное финансирование в рамках выпуска долговых обязательств («проектных» или «инфраструктурных» облигаций), полностью или частично гарантированных государством; иные способы непрямого государственного финансирования (налоговые кредиты, субсидирование процентных ставок по привлекаемым кредитам и т. п.)

Модернизация системь образования (в первую очередь естественнонаучного и профессионального), укрепление инженерных школ, среднего профессионального образова ния и профессиональной ориентации

Модернизация финансовых институтов

Активизация инноваций в области институтов гражданского общества

Социальная политика, комплементарная задачам модернизации и инновационного роста

Стимулирование энергоэффективности

Система государственной поддержки реализации программ обучения и стажировок специалистов предприятий на базе ведущих российских и зарубежных образовательных организаций; развития корпоративных и отраслевых центров повышения квалификации и сертификации персонала; «смежного» образования (технологического для менеджеров, экономического - для инженеров)

Развитие в рамках программ (стандартов) среднего и высшего образования креативных форм деятельности, обеспечивающих решение творческих задач в области науки и технологий

Стимулирование интеграции учебного и научного (инженерного) процессов в вузах

Поддержка квалифицированного труда (рабочих и инженеров), включая содействие созданию их профессиональных объединений

Развитие отраслевых систем ипотеки и жилищных программ, в том числе обеспечения съемным служебным жильем ведущих специалистов

Поддержка институтов, обеспечивающих всеобщую доступность качественного образования, включая высшее (отбор через олимпиады, кружки, профильные школы при вузах и др.)

Целенаправленное выращивание особых сегментов внутреннего долгового рынка, содействующих расшивке «узких мест» финансового сектора и более эффективному использованию его внутренней ресурсной базы за счет развития:

- рынков долгосрочных корпоративных облигаций как механизма трансформации имеющихся у банков кратко- и среднесрочных ресурсов в долгосрочные заимствования компаний

- синдицированного кредитования, объединяющего разрозненные ресурсы банковкредиторов для финансирования крупных займов российских компаний

- системы разделения рисков кредитования (и финансирования через эмиссию) между частными финансовыми институтами и государственными институтами развития

Обеспечение «договороспособности» российских компаний на мировом рынке и внутри страны через упрощение судебных и досудебных процедур урегулирования конфликтов Качественное укрепление «низовых» институтов (профсоюзов, союзов потребителей и т. д.)

Стимулирование диверсификации экономики за счет поддержки среднего бизнеса в регионах, обеспечивающего занятость высвобождающихся при модернизации работников

Поддержка программ профессиональной переподготовки занятых в модернизируемых производствах на специальности, имеющие спрос в регионе и соседних с ним территориях Содействие миграции в другие регионы, включая строительство дешевого жилья на основе софинансирования со стороны федерального центра, принимающего региона и регионадонора

Включенность граждан в глобальные сети обмена информацией; повышение уровня владе-

Развитие таких институтов, как: ния иностранными языками

- энергетический аудит, присвоение класса энергоэффективности бытовым приборам, промышленному и коммунальному оборудованию; вытеснение неэффективного оборудования посредством мер технического регулирования

- введение перспективных технических регламентов, стимулирующих повышение энергоэффективности, долгосрочную определенность для субъектов хозяйствования

- формирование на региональном уровне нормативных требований по энергоэффективности эксплуатации объектов капитального строительства для включения их в градостроительные регламенты территорий

Адаптация к вступлению России в ВТО (ликвидация «уютных» ниш, неэффективной защиты ряда секторов)

Субсидирование преодоления разрыва в процентных ставках на внешних и внутреннем кредитных рынках для улучшения условий доступа национальных компаний к кредитным ресурсам

Развитие практики страхования сделок и предоставления гарантий по кредитам, связанным с экспортными операциями

Стимулирование покупки активов и кооперации со странами-партнерами в производстве и продвижении продукции на рынки высокотехнологичной продукции

Маркетинговая и информационная поддержка отечественных экспортеров, в том числе. на базе сети торгпредств; использование этих сетей как инфраструктуры формирования консолидированной позиции российской стороны в переговорах с зарубежными контрагентами Политическая поддержка выхода на рынки высокотехнологичной продукции 
инновационной деятельности и политики. Принципиальное расширение социальной базы инновационной политики за счет учета интересов и особенностей различных групп населения (в том числе пенсионеров, людей с ограниченными возможностями, сельского населения, жителей моногородов и отдаленных, труднодоступных территорий, безработных, мигрантов и др.) является важнейшим ресурсом повышения ее эффективности.

Потенциал и значимость привнесения в отечественную инновационную политику адресности и ориентации на отдельные социальные группы определяются тем, что в России насчитывается около 13 млн лиц с ограниченными возможностями, 39.7 млн пенсионеров, 37.6 млн сельских жителей и иных, весьма многочисленных категорий населения, доступ которых к инновациям весьма жестко ограничен отсутствием как инфраструктуры и стандартов, обеспечивающих оказание инновационных услуг в социальной сфере и государственном управлении (в частности, телемедицина, дистанционное образование, информатизация органов социальной защиты и обслуживания населения, онлайновое предоставление государственных услуг), так и необходимых знаний и навыков.

Социальные разрывы во многом сдерживают рост предложения инноваций, их тиражирование, распространение и общественную поддержку. В связи с этим предлагаются мероприятия, направленные на улучшение доступа к инновациям различных слоев населения, усиление их вовлеченности в инновационные процессы.

В основе коренных институциональных изменений, ведущих к построению экономики знаний, лежит развитие в обществе инновационного мышления и духа предпринимательства, которые не могут сформироваться вне креативного класса, обеспечивающего создание в экономике знаний большей части добавленной стоимости. Именно креативный класс является носителем и распространителем инновационной культуры, поэтому важнейшей задачей государства и общества должно стать создание благоприятной среды для его развития. На сегодняшний день соответствующие группы населения сталкиваются с рядом проблем, которые приводят к масштабному оттоку его представителей за рубеж.

Создание комфортной для креативного класса юрисдикции возможно через глубокие институциональные изменения, а также построение локальных сообществ, приспособленных под нужды креативного класса (пример - проект Сколково). Помимо общепринятых мер, способствующих повышению ценности человеческого капитала (улучшение качества образования, поддержка фундаментальной науки и технологических бизнесов и т. п.), важны меры по защите личности, прав собственности (в том числе интеллектуальной), окружающей среды и т. п. Время конкуренции людей за юрисдикцию страны, предоставляющей защиту и гарантии, постепенно проходит; в условиях экономики знаний нарастает конкуренция государств за представителей креативного класса, формирующих инновационную среду.
В рамках инновационной политики предлагается уделить первоочередное внимание программам поддержки креативного класса и массового инновационного бизнеса, реализующего технологические и нетехнологические инновации. Действенными инструментами здесь могут стать различные адресные гранты, создание центров технического содействия, поддержка тематических форумов и конференций для развития партнерских связей.

Любые инновационные инициативы будут иметь лишь ограниченное действие, не смогут обеспечить масштабные и устойчивые позитивные изменения в структуре и темпах роста национальной экономики без соблюдения определенных базовых условий. Их отсутствие усиливает риски всевозможных имитаций инновационной деятельности, с одной стороны, и низкой результативности ее регулирования - с другой. Разработка соответствующих предложений относится к мандату других экспертных групп, задействованных в подготовке рекомендаций по Стратегии-2020, тем не менее мы сочли необходимым отметить некоторые проблемы, критически важные в контексте инновационного развития (табл. 7).

\section{Оценки масштабов расходов федерального бюджета на инновационную деятельность в гражданском секторе экономики на период до 2020 г.}

Хотя наиболее затратным для бюджета является прогрессорский сценарий развития инновационной сферы, эксперты считают, что только он позволит добиться ощутимого улучшения, достаточно быстро актуализировать инновационные интересы бизнеса, будет содействовать притоку в эту сферу значительных внебюджетных средств.

Оценка динамики расходов федерального бюджета на инновационную деятельность была проведена для трех сценариев инновационного развития (рис. 6). При расчетах в качестве целевых использовались структурные индикаторы, соответствующие ключевым параметрам эффективности экономики, в форме соотношений:

- инновационной продукции и общего объема отгруженных товаров (выполненных работ, услуг);

- затрат на инновации и общего объема отгруженных товаров (выполненных работ, услуг);

- затрат на ИиР и расходов на инновации;

- средств предпринимательского сектора и бюджета государства в затратах на ИиР;

- прямых затрат и косвенных издержек государства, связанных с развитием инновационной экономики.

Изменение пропорций между значениями данных показателей отражает глубину институциональных преобразований в экономике в связи с переходом к инновационной модели роста.

Для разработанных сценарных вариантов были выбраны различные значения целевых параметров с учетом горизонта прогноза: 


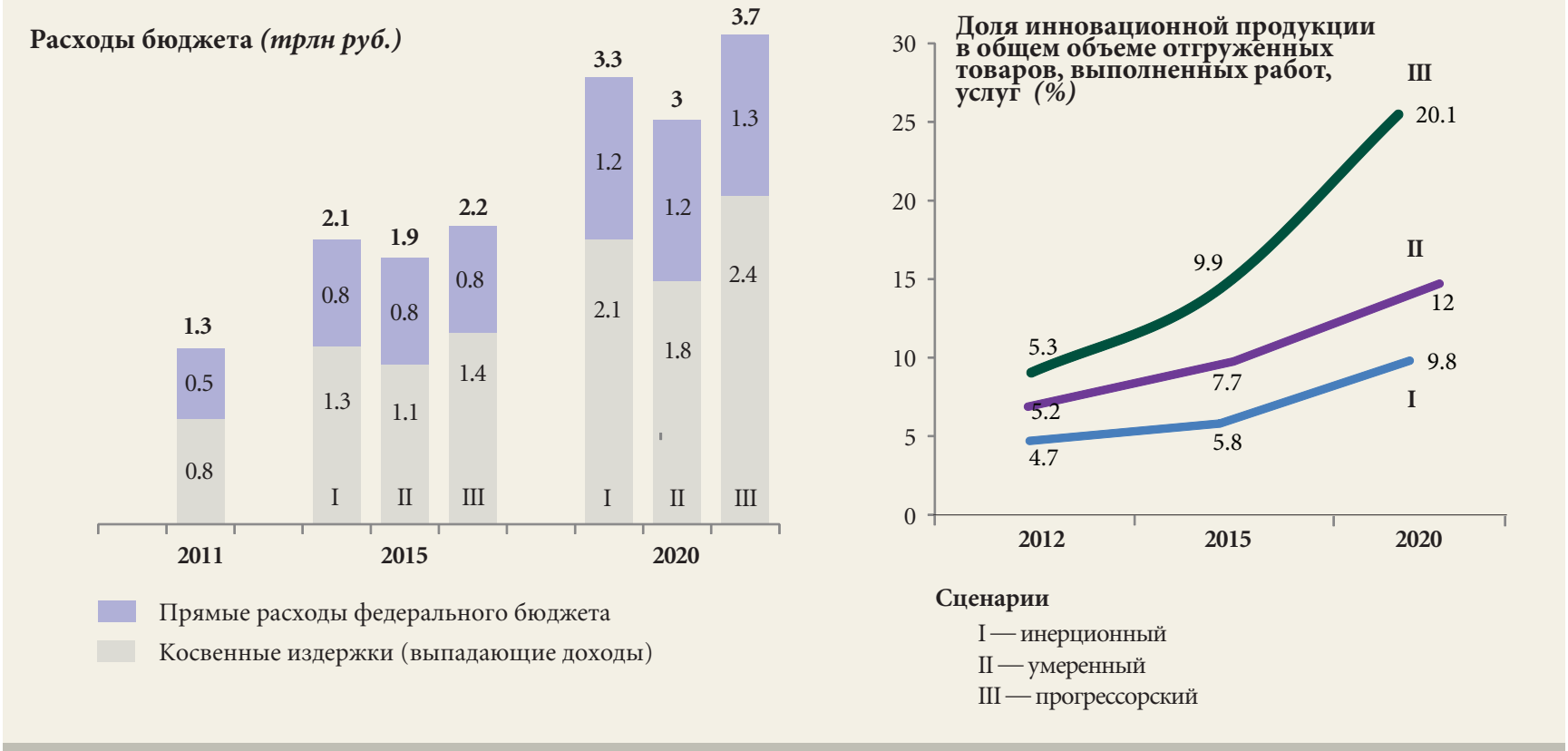

- инерционный - наиболее вероятные значения получены на основе экстраполяции сценарных параметров;

- умеренный — используются медианные значения сценарных параметров для стран - членов ОЭСР;

- прогрессорский — медианные значения сценарных параметров для группы наиболее развитых стран - членов ОЭСР (высшая децильная группа).

При оценке суммарной нагрузки на бюджет в связи с развитием инновационной сферы были выделены прямые затраты (в гражданском секторе науки) и косвенные издержки (выпадающие доходы бюджета в результате использования налоговых (фискальных) механизмов стимулирования инновационной активности).

Сравнительный анализ полученных результатов позволяет сделать вывод, что наиболее эффективным и наименее капиталоемким (в удельном отношении) среди трех возможных вариантов развития является прогрессорский, позволяющий к 2020 г. увеличить объем инновационных товаров (работ, услуг) в российской экономике до 14.4 трлн руб. (по добавленной стоимости - 9.3\% ВВП). При умеренном и инерционном сценариях соответствующие значения этих показателей не превысят 8.6 (5.6\% ВВП) и 7.0 трлн руб. (4\% ВВП). По сравнению с 2011 г. при реализации прогрессорского сценария объем инновационной продукции вырастет в 8.7 раза, что связано с «запуском» эффективных механизмов стимулирования (умеренный - 5.3, инерционный - 4.8 раза).

Проведение радикальных структурных, институциональных, инфраструктурных преобразований создаст основу для реализации эффективных механизмов использования ресурсов. Значимым результатом станет достижение российской экономикой в 2020 г. качественных параметров, характеризующих высокую отдачу затрат на инновационную деятельность. Соотношение объема инновационной продукции и таких затрат для прогрессорского сценария составит 7.1:1 (втрое выше, чем в 2011 г.); для умеренного - 6:1; для инерционного - 4.1:1.

При прогрессорском сценарии в результате применения комплекса эффективных стимулов можно рассчитывать на динамичный рост доли предпринимательского сектора в финансировании ИиР - с 27\% в 2011 г. до 73\% в 2020 г. Более медленный тренд ожидается при умеренном сценарии (40\% в 2020 г.). При инерционном развитии значение этого показателя фактически не изменится. В абсолютном выражении вклад предпринимательского сектора в финансирование ИиР при прогрессорском варианте достигнет в 2020 г. примерно 1.5 трлн руб., превысив уровень 2011 г. более чем семикратно. Умеренный и инерционный сценарии (соответственно 575 и 414 млрд руб.) не обеспечат необходимых условий для активизации инновационных процессов.

Использование современных инструментов стимулирования в прогрессорском сценарии позволит добиться оптимизации структуры источников финансирования ИиР, что считается отличительной чертой и важным параметром модели инновационного роста, характерной для развитых стран. Здесь в рамках горизонта прогнозирования будет обеспечено устойчивое увеличение доли средств предпринимательского сектора, других внебюджетных источников (в том числе иностранных). Ожидается, что при интенсивном стимулировании активности предпринимательского сектора объем средств государства в его затратах на ИиР в абсолютном выражении сохранится примерно на уровне 2011 г. и составит в 2020 г. 60 млрд руб.

Аналогичная динамика данного показателя будет наблюдаться и при умеренном сценарии. Напротив, 
при инерционном варианте сохранится устойчивая тенденция роста средств государства в затратах предпринимательского сектора на ИиР (334 млрд руб. в 2020 г., увеличение по сравнению с 2011 г. в 4.3 раза). В этом случае ожидается заметное ухудшение структуры финансирования: соотношение затрат предпринимательского сектора и средств государства снизится с 1:2 в 2011 г. до 1:4 в 2020 г.

Наряду с тенденцией замещения бюджетных расходов средствами бизнеса существенные сдвиги в структуре поддержки инновационной деятельности будут связаны с опережающей динамикой косвенных издержек государства по сравнению с прямыми затратами. Такая динамика будет обеспечена, прежде всего, за счет расширения системы налоговых льгот в реальном секторе экономики. В результате объем косвенных издержек государства в 2011-2020 гг. возрастет примерно втрое - почти до 2.5 трлн руб. В этот же период прямые затраты федерального бюджета вырастут в 2.5 раза. Примерно так же бу дут расти эти показатели в умеренном варианте при существенно меньших масштабах косвенных издержек государства. В случае инерционного развития сохранится тенденция роста прямой и косвенной нагрузки на бюджет, а значения результативных индикаторов будут существенно ниже, чем в двух других вариантах.

Таким образом, прогрессорский сценарий обеспечит наиболее кардинальные изменения в общей структуре финансирования инновационной деятельности. Хотя он и потребует дополнительных бюджетных расходов, но будет сопровождаться глубокими институциональными преобразованиями и повышением эффективности НИС, ощутимым увеличением объема внебюджетных инвестиций. В итоге реализация комплекса мер инновационной политики позволит не только избежать нереалистичных финансовых запросов к государству, но и разомкнуть существующие бюджетные ограничения за счет замещения прямого субсидирования инновационной активности косвенными регуляторами и частными инвестициями.

Как видно из рис. 6, наименее эффективным из предложенных сценариев является инерционный. Его отличают сочетание высоких затрат и минимального значения целевых показателей. Из-за сохранения неэффективных механизмов трансформации затрат на инновации в экономические результаты реализация этого сценария не обеспечивает в рамках рассматриваемого прогнозного горизонта достижения структурных параметров и пропорций, соответствующих современных трендам. Доля инновационной продукции в общем объеме отгруженных товаров (выполненных работ, услуг) в 2020 г. составит менее половины от уровня, достигаемого при прогрессорском сценарии (в условиях 10\%-го расхождения по масштабам суммарной нагрузки на бюджет).

Умеренный вариант привлекателен более низкими расходами бюджета. На фоне отдельных институциональных преобразований он может привести к некоторому улучшению целевых индикаторов, но их уровень, тем не менее, не позволит добиться принципиального изменения «инновационных» позиций России в мире.

Апокин А.Ю., Белоусов Д.Р. (2009) Сценарии развития мировой и российской экономики как основа для научно-технологического прогнозирования // Форсайт. № 3(11). С. 12-29.

Гохберг Л.М. (2003) Национальная инновационная система России в условиях «новой экономики» // Вопросы экономики. №3. С. 26-44.

Гохберг Л.М., Заиченко С.А., Китова Г.А., Кузнецова Т.Е. (2011) Научная политика: глобальный контекст и российская практика. М.: НИУ ВШЭ.

Гохберг Л.М., Кузнецова И.А. (2009) Инновации в российской экономике: стагнация в преддверии кризиса? // Форсайт. № 3(11). C. $28-46$.

Гохберг Л.М., Кузнецова Т.Е., Рудь В.А. (2010) Анализ инновационных режимов в российской экономике: методологические подходы и некоторые результаты // Форсайт. Т. 4. № 3. С. 18-30.

Инновационное развитие - основа модернизации экономики России (2008) Национальный доклад. М.: ИМЭМО РАН, ГУ-ВШЭ.

Мишарин А.С., Клепач А.Н., Белоусов Д.Р. (2011) Посткризисное развитие России: модернизация, инновации и социальное

государство. Перспективы до 2025 года. Екатеринбург: ОАО «ИПП «Уральский рабочий».

Российский инновационный индекс (2011) / Под ред. Л.М. Гохберга. М.: НИУ ВШЭ.

Россия в цифрах 2010. Краткий статистический сборник. М.: Росстат.

2009 Global R\&D Funding Forecast (2008) // R\&D Magazine, December.

European Commission (2009) Policy Mixes for R\&D in Europe. UNU-MERIT.

European Commission (2010) Europe-2020: A Strategy for a Smart, Sustainable and Inclusive Growth. Brussels.

OECD (2000) A New Economy? The Changing Role of Innovation and Information Technology in Growth. Paris. P. 7-8.

OECD (2008) OECD Reviews of Innovation Policy. China. Paris.

OECD (2009) Policy Responses to the Economic Crisis: Investing in Innovation for Long-term Growth. Paris. P. 5-10.

OECD (2010a) The OECD Innovation Strategy. Getting A Head Start on Tomorrow. Paris.

OECD (2010b) The Innovation Policy Mix. STI Outlook 2010: Chapter 4. DSTI/STP (2010)12. Paris.

OECD (2011) OECD Reviews of Innovation Policy. Russian Federation. Paris.

The Global Innovation Index 2011/ed. S. Dutta. Fontainbleau: INSEAD.

Therrien P. (2010) R\&D Tax Incentives and Government Forgone Tax Revenue: a Cross-Country Comparison. DSTI/EAS/STP/NESTI(2010)22 8-10 November 2010. Paris: OECD. 


\title{
Strategy 2020: New Outlines of Russian Innovation Policy
}

\begin{abstract}
$\mathrm{T}$ The paper presents the outcomes of the expert group "The transition from fostering innovation to innovation-based growth" on adjusting the Strategy for socio-economic development of Russia up to 2020 . Panel experts have undertaken a detailed analysis of the state of art of the Russian innovation sphere and proposed recommendations on the choice of strategic priorities for state policy, as well as specific regulatory tools that can be implemented in the near future.

Among the key challenges identified are: the increasing Russian dependence on foreign markets, the growing socioeconomic risks, difficulties with adequate responding to the rapidly changing global trends, significant gaps between the main actors of the innovation system, sufficient lack of access to new technologies and innovations for different social groups. The most significant positive trends include: the introduction of new regulatory tools, the gradual expansion of the actors players in the innovation sector and, the growth of public R\&D funding.

The experts propose three possible scenarios: the inertial scenario implies low rates of economic growth while preserving the dependence of the economy on extractive industries; the progressive scenario presumes the accelerated integration into global processes and transition to postindustrial model and the moderate scenario which has the highest probability of realization. The implementation of a

scenario depends on political choices made in the context of bifurcation in areas such as legislation, regulation, science, and many others. For example, in education there is a need to choose between "soft" adaptation of existing educational programs to meet the changing needs of the economy and greater emphasis on the development of specific professional skills.

The paper formulates the basic directions of a prospective innovation policy: shifting from focusing on support for individual innovative projects that meet tight technology priorities to fostering mass innovation in all sectors of the economy, including low-tech ones; sectoral differentiation of the priorities, criteria, policy instruments, balanced support for innovation in high- and low-tech sectors, the rejection of a rigid hierarchy in the governance in favor of decentralization, empowerment of regions, development institutions, business associations and other entities with more power; support for network cooperation at all levels, focusing on an output-oriented approach to decision making, ensuring the balance of thematic and functional priority policies in order to eliminate possible failures in the innovation cycle. The authors put emphasis on the social effects of innovation policy, the need for supporting the creative class as well as the training of entrepreneurs, managers and professionals for the innovation sector and the economy as a whole.
\end{abstract}

\section{Keywords}

expert group, scenario, innovation strategy, decision-making, innovation policy, innovation performance, incentives for innovation

\section{References}

2009 Global R\&D Funding Forecast (2008). ReD Magazine, December.

Apokin A.Yu., Belousov D.R. (2009) Stsenarii razvitiya mirovoi i rossiiskoi ekonomiki kak osnova dlya nauchno-tekhnologicheskogo

prognozirovaniya [Scenarios of the Global and Russian Economic Development as a Basis for S\&T Forecasting]. Foresight-Russia, vol. 3, no 3, pp. $12-29$.

European Commission (2009) Policy Mixes for R\&D in Europe, UNU-MERIT.

European Commission (2010) Europe-2020: A Strategy for a Smart, Sustainable and Inclusive Growth, Brussels.

Gokhberg L.M. Natsional'naya innovatsionnaya sistema Rossii v usloviyakh novoi ekonomiki [Russia’s National Innovation System in the framework of a New Economy]. Voprosy economiki, no 3, pp. 26-44.

Gokhberg L. M. (ed.) (2011) Rossiiskii innovatsionnyi indeks [Russian Innovation Index], Moscow: HSE.

Gokhberg L.M., Kuznetsova I.A. (2009) Innovatsii v rossiiskoi ekonomike: stagnatsiya v preddverii krizisa? [Innovation in the Russian Economy:

Stagnation before Crisis?]. Foresight-Russia, vol. 3, no 2, pp. 28-46.

Gokhberg L.M., Kuznetsova T.E., Roud V.A. (2010) Analiz innovatsionnykh rezhimov v rossiiskoi ekonomike: metodologicheskie podkhody i nekotorye rezul'taty [Analysis of Innovation Modes in the Russian Economy: Methodological Approaches and First Results]. Foresight-Russia, vol. 4 , no 3, pp. 18-30.

Gokhberg L.M., Zaichenko S.A., Kitova G.A., Kuznetsova T.E. (2011) Nauchnaya politika: global'nyi kontekst i rossiiskaya praktika [Scientific Policy: Global Context and Russian Practice], Moscow: HSE.

HSE, IMEMO (2008) Innovatsionnoe razvitie - osnova modernizatsii ekonomiki Rossii. Natsional'nyi doklad [Innovation Development as a Basis for the Russia’s Economic Modernization. National Report], Moscow.

Dutta S. (ed.) (2011) The Global Innovation Index 2011 Fontainbleau: INSEAD.

Misharin A.S., Klepach A.N., Belousov D.R. (2011) Postkrizisnoe razvitie Rossii: modernizatsiya, innovatsii i sotsial'noe gosudarstvo. Perspektivy do 2025 goda [Russia's Post-Crisis Development: Modernization, Innovation and Social State. Prospects towards 2025], Ekaterinburg: Ural'skii rabochii.

OECD (2000) A New Economy? The Changing Role of Innovation and Information Technology in Growth, Paris, pp. 7-8.

OECD (2008) OECD Reviews of Innovation Policy. China, Paris.

OECD (2009) Policy Responses to the Economic Crisis: Investing in Innovation for Long-term Growth, Paris, pp. 5-10.

OECD (2010a) The OECD Innovation Strategy. Getting A Head Start on Tomorrow, Paris.

OECD (2010b) The Innovation Policy Mix. STI Outlook 2010 (Chapter 4: DSTI/STP (2010)12), Paris.

OECD (2011) OECD Reviews of Innovation Policy. Russian Federation, Paris.

Rosstat (2010) Rossiya v tsifrakh 2010. Kratkii statisticheskii sbornik [Russia in Figures. Brief Statistical Book], Moscow.

Therrien P. (2010) RઐD Tax Incentives and Government Forgone Tax Revenue: a Cross-Country Comparison (DSTI/EAS/STP/NESTI (2010)22 8-10 November 2010), Paris: OECD. 


\section{Креативность и взаимодействие Пространства роста для российского Форсайта}

Люк Джорджиу, вице-президент Университета Манчестера (Великобритания) - один из ведущих в Европе экспертов в области Форсайта и инновационной политики.

Анализируя события и тенденции последних пяти лет, на протяжении которых издается журнал «Форсайт», Л. Джорджиу оценивает перемены и зарождающиеся тенденции, способные радикально изменить картину мира, а также характеризует достижения российского Форсайта и возможные направления его дальнейшего развития.

Как Вы оцениваете прогресс в области Форсайтисследований и инновационной политики за последние пять лет?

Я бы отметил заметный прогресс в обеих сферах и их вклад в предупреждение глобального кризиса и минимизацию его последствий. Так, на уровне формирования инновационной политики закрепилось осознание важности факторов, формирующих рыночный спрос и благоприятный инновационный климат, включая конкуренцию, налоговые режимы, охрану интеллектуальной собственности, наличие предпринимательской культуры, финансовое обеспечение и т. п.

Каковы возможные варианты преодоления текущего глобального кризиса?

Прежде всего, необходимо повышать производитель ность существующих индустриальных и сервисных секторов и создавать новые. В основе обоих процессов лежат инновации, и вероятность их успеха существенно повышается в результате эффективного применения Форсайта. Его ключевая роль - в согласовании интересов и координации действий ключевых игроков инновационной системы. Наличие общего видения повышает вероятность появления системных технологий, например, новых видов транспорта или способов производства энергии.

Какие «великие вызовы» предстоит преодолевать международному сообществу и национальным правительствам в ближайшие 10-15 лет?

Сегодня наблюдается единодушие в отношении перечня определенных долгосрочных задач, включая достижение устойчивого развития, обеспечение основными ресурсами для жизнедеятельности, адаптацию к изменению климата, охрану здоровья, демографические аспекты и т. п. Существуют и «скрытые» пока проблемы, выявление которых и их донесение до лиц, принимающих решения, является критически важной ролью Форсайт сообщества. Глобальный экономический кризис как раз из списка подобных неявных вызовов, о которых эксперты предупреждали, но не были услышаны. «Слабые сигналы» присутствуют всегда - вопрос в том, какие из

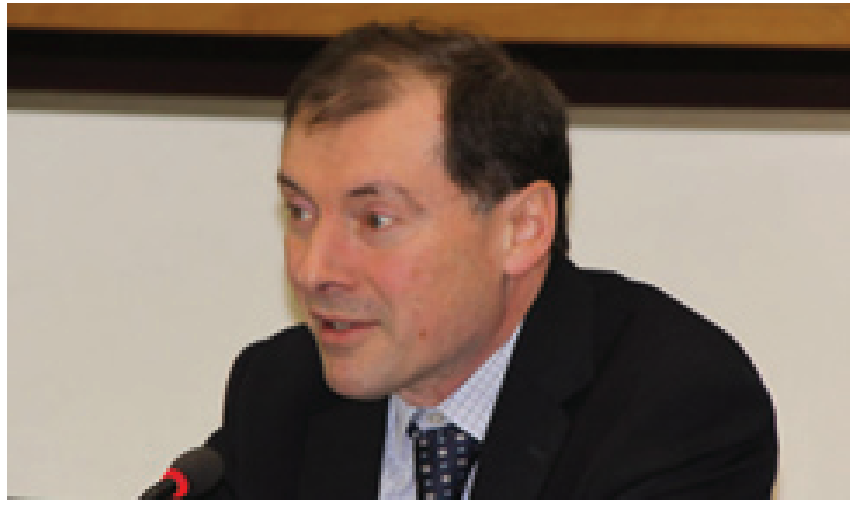

них учитывать. Я бы рекомендовал обратить внимание на следующие:

- возможность распада Китая на ряд полуавтономных территорий;

- снижение репродуктивности мужчин в западных странах, что негативно скажется на рождаемости;

- прорывные открытия в сфере нанотехнологий существенно повысят эффективность преобразования световой энергии в электрическую;

- вероятность возврата к протекционизму;

- продовольственный дефицит станет толчком для развития сельского хозяйства и смежных с ним сфер;

- укрепление «экологической» парадигмы;

- усиление локализации туризма, вызванное геополитической нестабильностью, ростом транспортных расходов и рядом других факторов.

Какие основные тенденции развития Форсайта Вы выделяете в России?

Уровень Форсайта в России впечатляет. Как председатель Международного консультативного совета Форсайт-центра ИСИЭЗ НИУ ВШЭ, я бы отметил работу по составлению перечня критических технологий, который служит источником ценной информации о зарождающихся экономически значимых направлениях в различных областях.

Интернационализация ИСИЭЗ - весьма позитивное явление, поскольку большинство изучаемых трендов и сигналов носят глобальный характер. Институт может служить своеобразным «окном в мир». Считаю, что результаты реализованных проектов должны обсуждаться более широко, прежде всего, на уровне государства и бизнеса и стать основой совместных стратегий. Этому способствует организация «сетевых» мероприятий.

По версии Р. Поппера Форсайт характеризуется четырьмя методологическими «полюсами»: экспертизой, доказательностью, взаимодействием и креативностью. Если первые два в России развиты достаточно высоко, то с последней пока еще возникают существенные трудности. Что касается взаимодействия, его добиться значительно легче; как следствие, повысится результативность Форсайтной деятельности в целом. 


\section{Будущее городов \\ Города как агенты глобализации и инноваций}

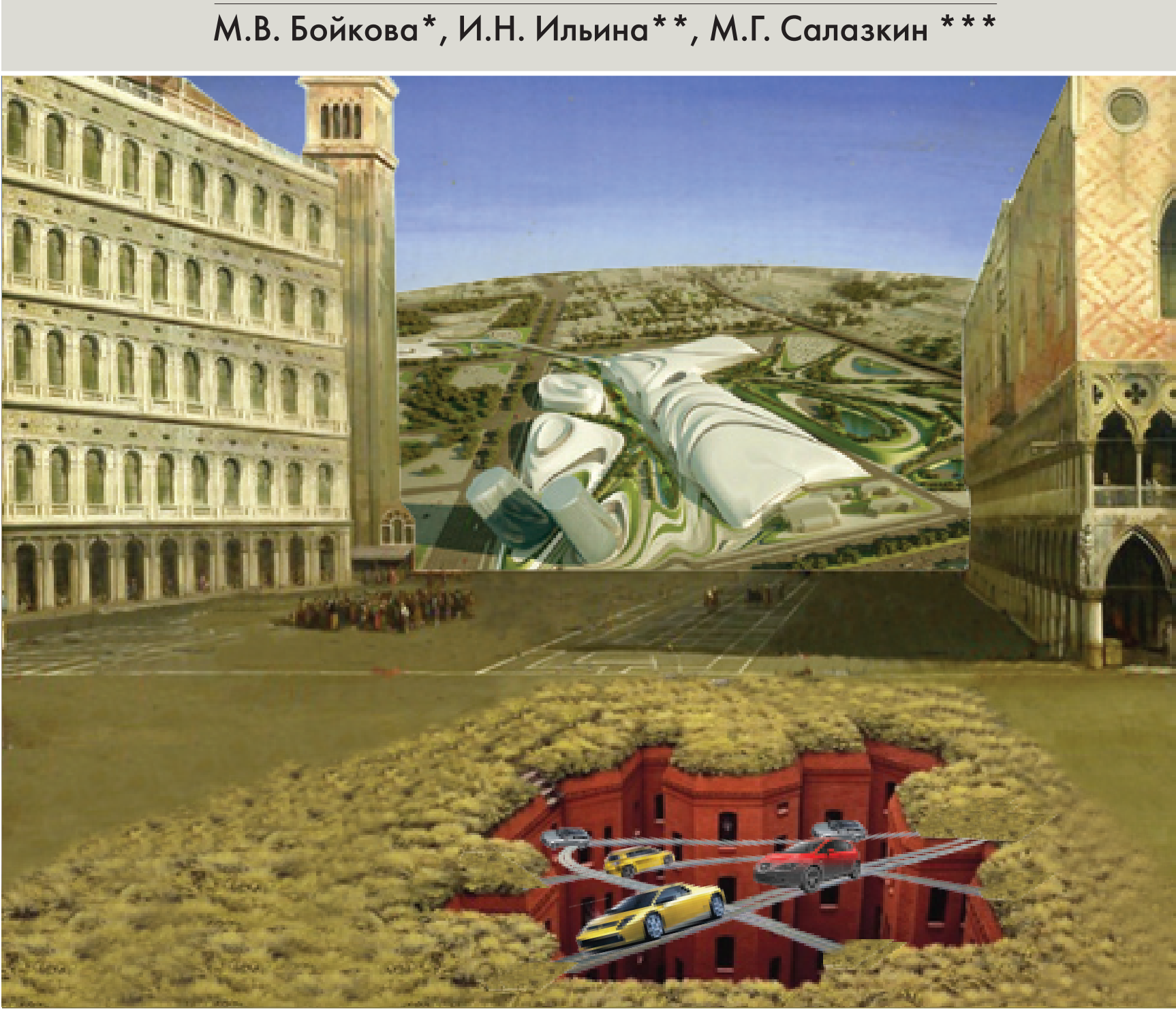

Урбанизация как глобальный социально-экономический процесс стремительно перекраивает картину мира. В XXI в. мегаполисы становятся центрами экономического роста, базой новейших знаний и технологий, полигоном для апробирования самых смелых инновационных концепций. Чтобы сформировать новый облик городов и качество жизни их населения, необходимы гибкие стратегии, созданные на междисциплинарной основе, позволяющие выявить и активизировать потенциальные источники роста.

Ключевые слова: стратегия городского развития, городское население, агломерация, урбанизация, смена парадигмы, глобальный город, мегаполис, мировой город, креативныи город, экогород, умный город

\footnotetext{
* Бойкова Марина Васильевна - ответственный редактор, журнал «Форсайт». Адрес: Национальный исследовательский университет «Высшая школа экономики», 101000, Москва, Мясницкая ул., 20. E-mail: mboykova@hse.ru

** Ильина Ирина Николаевна - директор, Центр региональных исследований, Институт региональных исследований и городского планирования НИУ ВШЭ. Адрес: Национальный исследовательский университет «Высшая школа экономики», 101000, Москва, Мясницкая ул., 20. E-mail: iilina@hse.ru

*** Салазкин Михаил Геннадьевич - младший научный сотрудник, ИСИЭЗ НИУ ВШЭ. Адрес: Национальный исследовательский университет «Высшая школа экономики», 101000, Москва, Мясницкая ул., 20. E-mail: msalazkin@hse.ru
} 


\section{Современный контекст городского развития}

Стремительный, экспоненциальный рост численности городского населения повлек за собой расширение и радикальную трансформацию городов. Количественные показатели данного процесса наглядно иллюстрируются в докладе IBM: в мировом масштабе городское население каждую неделю прирастает на 1 млн чел., за год «набегает» семикратная численность жителей такого города, как Нью-Йорк [IBM, 2009a]. В Европе доля городских жителей уже превышает $75 \%$, а в развивающихся странах она близка к отметке $50 \%$.

В настоящее время число городов-миллионников в мире превышает 300, темпы их прироста только увеличиваются. В середине прошлого века городамиллионники имела лишь каждая седьмая страна, а сегодня - уже каждая третья. Всего, по состоянию на 2008 г., в мире насчитывалось 459 агломераций с населением более 1 млн чел., в которых проживало примерно $40 \%$ горожан и $20 \%$ всего населения планеты. В 2009 г. наступил «переломный момент»: городское население планеты по численности превысило сельское, между тем, еще двадцать лет назад оно составляло менее трети мирового населения. По оценкам ООН, к 2050 г. общемировая численность городского населения вырастет на 2.3 млрд чел. и составит $70 \%$ от всего населения Земли [UN, 2009].

Неконтролируемый рост населения городов сопровождается возникновением сверхнаселенных территорий, характеризующихся столь высокой концентрацией социально-экономической деятельности, что она выходит за установленные административные и политические границы. Усиление разнообразных связей между близко расположенными населенными пунктами способствует превращению города в более сложную форму расселения - географическую агломерацию, которая в некоторых случаях обретает транснациональный статус, объединяя урбанизированные территории, находящиеся на стыке национальных границ. Наиболее характерная иллюстрация - Базель-Мюлуз-Фрайбург (Швейцария, Франция, Германия) и КопенгагенМальме (Дания, Швеция) [IBM, 2009a].

Тема развития городов и сопряженные с ней новые знания и исследования представляют собой обширное информационное поле. Города изучаются по разным параметрам, в различных аспектах; постоянно предпринимаются попытки их концептуализировать, ранжировать и классифицировать. Тем не менее, при обилии современных методик и подходов в изучении этой сферы имеются определенные пробелы. Город в XXI в. представляет собой сложнейшую турбулентную систему, развитию которой присуща высокая степень неопределенности, что сильно затрудняет глубокий и всесторонний анализ ее структур. Эксперты все чаще рассматривают крупные города как сложно сконструированные системы, с огромным количеством переплетенных и неисследованных зон и взаимосвязей, которые в принципе поддаются выявлению [Jacobs, 1993].
Городам по их природе свойственна высокая степень непрозрачности, что затрудняет идентификацию тех или иных процессов [Лэндри, 2011]. Несмотря на наличие современного аналитического инструментария, включающего сложные математические модели и постоянно совершенствующегося, анализом охвачены в основном долговременные процессы, лежащие «на поверхности» и носящие массовый характер [Вендина, 2010].

В нашей статье мы представим трансформационные процессы и зарождающиеся в XXI в. тенденции урбанизации, связанную с ними смену парадигмы в городском развитии, инновационные модели развития городов и логику, из которой они истекают. Кроме того, проанализируем возможный будущий контекст городов. Перечисленные аспекты рассмотрим сквозь призму условно выделенных нами категорий городов:

- глобальные города-«магниты», обладающие статусом столицы и/или крупнейшего экономического центра;

- города-«стратеги», внедряющие инновационные концепции развития и ставящие приоритетом формирование высоких стандартов жизни на основе новейших технологий;

- города-«новаторы», пережившие кризис (как правило, вследствие упадка традиционных секторов, на которых базировалась их экономика), но сумевшие применить новаторский подход в создании новых источников роста и привлечении необходимых ресурсов.

Условность предложенных категорий состоит в динамичном перетекании и многоаспектности развития городов («магниты» могут быть и «стратегами», и «новаторами» одновременно, «стратеги» — «новаторами» и т. д.). На их примерах мы проанализируем, каким образом смена парадигмы отражается на «содержании» отдельных городов и как она может повлиять на будущие модели развития.

\section{Урбанистический ландшафт. Города-«магниты»}

Крупнейшие города обладают неким магнетизмом пространства, предоставляющим обилие беспрецедентных возможностей, динамичный высокотехнологичный мир, моментальные коммуникации через границы часовых поясов, функционирование круглосуточных производственных процессов, и обещают практически безграничные перспективы реализации человека. Глобальные города и крупнейшие мегаполисы никогда не входили в «топ» по качеству жизни, а причины их магнетизма всегда базировались на иных факторах, в частности таких как финансово-экономическое и политическое могущество.

Являясь ключевыми рынками занятости, такие города абсорбируют нарастающие миграционные потоки. Наделенные колоссальными финансовыми, управленческими, информационными и политическими функциями, мегаполисы развитых стран функционируют уже в постиндустриальной реальности. Присутствие головных офисов большинства 
транснациональных корпораций, ведущих медиаконцернов, компаний - провайдеров телекоммуникационных услуг, наличие информационных систем и технологий, превращает города в крупные информационные центры и логистические мегахабы.

В 1990-е гг. для описания подобных городов профессором социологии Чикагского университета С. Сассен был предложен термин «глобальный город», получивший широкое распространение [Sassen, 1994]. Она выделяет несколько причин возникновения этого феномена. Прежде всего - необходимость формирования соответствующей инфраструктуры для транснациональных компаний, расширяющих свое мировое присутствие за счет передачи второстепенных или непрофильных функций на аутсорсинг в развивающиеся страны. Чем шире в географическом плане распределена операционная деятельность корпорации, тем сложнее ее центральные стратегические функции - управление, координация, обслуживание, финансирование и т. п. По мнению С. Сассен, процесс глобализации, фактически, познается через анализ причин сосредоточенности ключевых структур мировой экономики в городах. В этом отношении подобные города имеют не просто узловое значение для экономической системы, но и являются отдельными центрами для производства. Глобальные города служат опорными точками циркуляции людских потоков, предоставляя площадку для официальных, деловых, научных, представительских и иных контактов самого разного рода, сюда прибывают для работы, обучения, отдыха и т. п. Первая десятка в рейтинге подобных городов аккумулирует более $10 \%$ всех международных туристических потоков и поглощает львиную долю самого крупного сектора делового туризма - корпоративных поездок. География связей мегаполисов чрезвычайно обширна, их «форланд» - практически весь мир.

Современную классификацию предлагает Группа по исследованию глобализации и мировых городов (Globalization and World Cities Study Group, GAWC) из британского Университета Лафборо (Loughborough University) [Parnreiter, 2009]. Города ранжируются в рамках следующих функциональных измерений: бизнес-активность, человеческий капитал, вовлеченность в политику, информационный обмен, культурная ценность. В зависимости от суммы набранных баллов города поделены на четыре ранга и 12 категорий (12-я - высшая, 1-я - низшая). По результатам анализа выделены 55 глобальных городов разного ранга, из них четыре (Лондон, Нью-Йорк, Париж, Токио) вошли в «элитный клуб», а другие 67 имеют достаточный потенциал, чтобы в будущем стать глобальными.

К 2010 г. статус глобальных приобрел 21 крупнейший мегаполис мира, причем 11 из них являются столицами государств. В настоящее время в мегаполисах проживает примерно каждый десятый горожанин (9.4\%), или каждый двадцатый житель Земли. Согласно новейшей тенденции, в развитых странах рост мегаполисов замедляется, тогда как в развивающихся - ускоряется [Siemens, 2006]. В Китае, где в строительство новых городов уже вложены сверхресурсы, в ближайшее десятилетие прогнозируется миграция сельского населения в мегаполисы в количестве 380 млн чел., что по численности превышает население США [The Economist, 2011].

\section{Тенденции}

Приходит понимание того, что необходимо в корне пересмотреть подходы к планированию городской среды. Чтобы переосмыслить сферу градостроительства, нужно открыть ее новые грани. Решения для этого могут быть разнообразные. Следует учитывать, что каждый город имеет свою специфику и уникальные черты, а потому универсальных решений не существует. В этом смысле очень важно понять, как правильно трансформировать город и что может сократить продолжительность этого процесса?

В обобщенном виде наблюдаемая сегодня смена парадигм в развитии городов заключается в следующем:

- происходит перемена базовых концепций: на смену образам «город как офис», «город-машина» (линейное и фрагментарное мышление, жесткий рационализм) приходят модели «город для жизни», «город, способствующий здоровому образу жизни» (междисциплинарное, новаторское мышление, учитывающее, прежде всего, психологию населения и т. п.);

- приобретает актуальность сочетание подходов «город как проект» и «город как мозаика проектов».

Новая философия урбанизма ориентирована на теорию креативного города. Он характеризуется как место, которое благоприятствует воплощению смелых новаторских инициатив с вовлечением максимального количества людей; место, где по-новому подходят к решению социально-экономических задач; место, которое позволяет быть на переднем крае компетенций; место, образ которого формируется не только архитекторами и урбанистами, но и всем населением; место коллективного творчества жителей. Подобная логика позволяет «увидеть» массу созидательных ресурсов, позволяющих сформировать «город для жизни». Это - творческие индустрии (интенсивно растущий сектор экономики), медиа-среда, искусство и, конечно же, население как носитель знаний и нового мышления. Креативный потенциал развития может в полной мере раскрыться при выполнении следующих базовых требований:

- формирование институциональной среды, благоприятствующей созданию и распространению инноваций;

- обеспечение возможностей для взаимного обогащения разнообразными ресурсами;

- гармоничное сочетание привычных явлений и нововведений;

- оптимальная планировка города в сочетании с дорожной и транспортной инфраструктурой, максимально облегчающей внутригородские перемещения; 
- умение созидать и привлекать образованных, талантливых, творческих людей.

Каким образом новая концепция развития может «работать» в сегодняшнем контексте? Мы попытались сопоставить новые «содержательные» схемы и «теряющие актуальность» установки в ряде ключевых срезов городской реальности.

\section{Интеллектуальная экономика}

Научно-технологический прогресс и инновационная активность спровоцировали перемену не только расклада сил в экономике, но и самого вектора ее развития. Мегаполисы в развитом мире функционируют в условиях постиндустриальной экономики.

Концентрация высокотехнологичного бизнеса, сложные транспортные и логистические сети, финансовые, юридические, информационные и коммуникационные инновации (включая электронное правительство и т. п.) - обычная картина городской жизни. Природа интеллектуальных услуг предполагает обмен знаниями между поставщиком услуги и ее потребителем, поскольку каждая из сторон вынуждена вникать в специфику сферы деятельности контрагента. Как следствие, имеет место эффект взаимного наращивания инновационного потенциала [Дорошенко, 2011]. Процесс «подпитывается» сферой ИКТ, постоянно обеспечивающей зарождение и развитие новых предложений (продуктов и услуг), которые для города являются, с одной стороны, источником жизнедеятельности, а с другой - магнитом для притяжения молодых, динамичных кадров.

Интеллектуальные услуги повсеместно имеют тенденцию концентрироваться в мегаполисах, где возможен доступ к широкому спектру знаний не только локального, но и международного происхождения. Несмотря на наличие развитых информационно-коммуникационных каналов, связывающих «центр» с «периферией», интеллектуальные компании предпочитают мегаполисы, так как здесь имеется возможность в ходе живого общения с партнерами обмениваться неявными знаниями, тем самым, наращивая свое конкурентное преимущество [Simmie, Strambach, 2006]. В городах формируется особый динамичный высокотехнологичный мир, и в этом смысле они выступают агентами экономики знаний.

Следом за информационной основой экономики утверждается креативная, которая приводит в движение творческие индустрии, все чаще выступающие новыми источниками городских доходов (туризм, дизайн, культурные мероприятия и т. п.). Наличие симбиоза между интеллектуальными услугами, креативной сферой и экономикой города в целом создает благоприятные условия для взаимного обогащения идеями и компетенциями, характеризующегося концептуальным определением learning city. Bсе перечисленное служит драйвером инноваций, повышающих конкурентоспособность территории.

\section{Новая организация жизненного пространства}

Основой формирования нового жизненного пространства является желание населения, прежде всего его высокообразованной части, влиять на среду своего нынешнего либо будущего обитания. В США проводится регулярный опрос жителей ряда ведущих городов, входящих в обозначенную категорию. Еще пятнадцать лет назад на вопрос «Что вы выберете: комфортный и классный город или высокооплачиваемую работу?» 80\% отвечали: «Работу». Сегодня уже $2 / 3$ респондентов отмечают, что предпочтут комфортную городскую среду, нежели престижное место занятости [Лэндри, 2011].

Десятилетиями в подходах к планированию городов доминировал жесткий рационализм, совершенно не учитывавший психологические эффекты, которые формируемая среда окажет на ее жителей. Так, для людей, которые часто и много передвигаются по городу, культура и эстетика внешнего окружения очень важный фактор. Агенты новой экономики, исходя из представлений о современной комфортной среде обитания, заинтересованы в соответствующем урбанистическом ландшафте. Тем самым формируется запрос на яркое многообразное окружение с уникальной историко-культурной концепцией места. Если в городе инновации формируются «снизу-вверх», его креатив позволяет объединить все элементы в единое гармоничное, наполненное жизнью пространство. Так, в Филадельфии (США) создана уникальная «паутина», которая объединяет город и университетский кампус таким образом, что там непременно встречаются люди разных возрастов. Эта «паутина» - результат специальной стратегии, предполагающей вовлечение старшего поколения в жизнь молодежи. Ее формирование впоследствии имело колоссальный эффект для всего города.

Крайне актуальной темой пространственного развития становится сохранение национальных особенностей городов, их историческая уникальность. Сегодня «память о прошлом» становится ценным ресурсом. Гармоничные города придают ей новое содержание. Для инвесторов указанный фактор становится немаловажным критерием для принятия решений. Показательный пример - Эмшер-парк (Рур, Германия), который детальнее будет рассмотрен ниже. Здесь «прошлое» было переосмыслено и использовано по-новому в целях органичного развития в перспективе. Прогулка по этому пространству как территории «прошлого» стимулирует размышления о будущем. Но даже при осознании нового «запроса» в поиске выигрышных решений местный историкокультурный капитал игнорируется, а бездумно копируется опыт других городов. В результате по всему миру наблюдается гомогенная смесь зданий: аквариумов, конференц-залов, моллов и ресторанов [Douglass, 2002].

Инновационно-креативная экономика требует реорганизации жизненного пространства в сторону повышения открытости и социального обмена, когда генерация идей идет «снизу вверх». Однако 
не все грандиозные проекты жизнеспособны. Есть и другие подходы, в которых «креативный» не значит «живой». Пример - Абу-Даби и Дубай, где в формировании сверхурбанистической среды применялась политика продавливания инноваций «сверху вниз». В середине 1990-х гг. пустынное побережье Персидского залива превратилось в полигон для реализации сверхамбициозных проектов, поражающих масштабностью и респектабельностью, многие из которых вошли в Книгу Гиннесса. Здесь был создан совершенно нетипичный для данной местности «высокотехнологичный» ландшафт, который, однако, не смог воспроизвести настоящую гармоничную социокультурную среду, свойственную западному миру.

\section{Транспортные коммуникации}

Гармоничный город, помимо прочего, подразумевает легкость передвижения из одной точки в другую. Современные подходы выстроены на желании решить проблему: город для автомобилей или город для людей? Во всех городах мира идет борьба за освобождение улиц от автомобильной инфраструктуры. Транспорт «прячется» под землю.

Так, французский проект Большого Парижа основан на идее восстановления тесного эмоционального контакта жителей с городом и ощущения его как целостного пространства, а не набора элементов, связанных между собой информационными каналами и транспортом. Формируется новый тип инфраструктуры - «экофреймы», представляющие собой большие подземные структуры, интегрирующие скоростной железнодорожный транспорт, метро, автомобильные дороги и инженерные коммуникации. Шесть радиальных экофреймов свяжут центральную часть Парижа с периферией. С уходом транспорта под землю решаются сразу несколько задач: на месте дорог создаются парки, улучшается состояние окружающей среды, в зоне отчуждения бывших железнодорожных путей высвобождается место для нового строительства. Другой пример - Сеул, где вернули на поверхность реку, ранее заключенную в коллектор. Сегодня река в естественном «зеленом» оформлении служит главным местом встреч горожан, а транспортные потоки грамотно перераспределены по другим направлениям.

\section{Экология}

Города неизбежно оказывают серьезную нагрузку на окружающую среду, требуя обеспечения жизненно важными ресурсами, с одной стороны, и утилизации отходов, с другой. Решения этих задач в контексте интеллектуальной экономики находятся в сфере новых технологических предложений, таких как экологический аудит и природоохранные технологии, имеющие свое продолжение в «зеленом бизнесе». Вводится понятие «экологического благополучия» с точки зрения таких параметров, как загрязнение воздуха, шум, использование и утилизация отходов, пробки на дорогах и озеленение территорий. Стоит упомянуть международную программу «Экологический след» (Ecological Footprint).
Ее целью является обеспечение устойчивого развития на основе комплексного индикатора, представляющего собой специальную систему оценки интенсивности использования природных ресурсов с учетом их способности к самовосстановлению.

Кроме того, гармоничный город - это новая, «зеленая» эстетика существования, эколого-ориентированный образ жизни, которые стимулируют экологически ответственное поведение горожан. В данной концепции доминирует созидательный принцип: сама окружающая среда «подсказывает» варианты новых «зеленых» проектов. Критическая масса подобного рода проектов может потенциально изменить само понимание «красоты» в городе. При новом подходе, например, солнечные батареи становятся привлекательным элементом архитектуры.

В ряде городов получила распространение идея «зеленой линии»: объекты культурного наследия гармонично сочетаются с современными зданиями за счет введения дополнительных дизайнерских элементов. В Милане (Италия), в частности, городские парки связывают друг с другом в единую непрерывную, но проницаемую сеть, которая структурирует территорию, препятствуя хаотическому расползанию застройки. Таким образом, компенсируются негативные эффекты, вызванные высокой плотностью застройки, создается ощущение безопасности и комфорта, маскируются неудачные архитектурные решения.

«Экологическое» мировоззрение формируется при помощи новаторских образовательных подходов, которые «втягивают» жителей города в экологическую тему на интеллектуальном и эмоциональном уровнях, а новые технологические решения позволяют реализовывать самые смелые идеи. Это хорошо демонстрирует шведский проект «Зона смещения солнца». Он представляет собой комплекс жилых зданий, построенных по специальной технологии, где каждый житель имеет возможность производить больше энергии, чем потреблять, благодаря чему получает деньги от национальной энергетической компании. Здания построены так, что стены, стекла, крыши, имеющие особую структуру, внешне не отличаются от обычных. Единственный примечательный атрибут такого квартала - обильная зелень.

В свое время Норвегия возглавила движение «экополисов»: удобная планировка; детские площадки; зеленые зоны, занимающие до 40\% территории города; здания с нулевым уровнем выбросов парниковых газов, оснащенные интеллектуальными счетчиками, солнечными батареями и ветрогенераторами; заправочные станции для электромобилей. Сегодня оно распространилось в Австралии, Нидерландах, США, Швеции, Германии. В последней появилось не менее 50 экопоселений, внутригородских оздоровительных зон, проектов отдельных экодомов. В Великобритании официально одобрен план раз вития четырех экогородов. Их концепция ориентирована на эффективное жилищное строительство и решение проблем, связанных с изменением климата. К 2020 г. здесь предусматривается построить до 
десяти подобных городов, а четыре пилотных проекта, по словам премьер-министра Великобритании, возглавят британскую «зеленую революцию», сняв одновременно проблему дефицита доступного жилья [Бокарева, 2009].

\section{Инновации}

Инновации в городах рассматриваются как инструмент придания им «магнетизма»в одних случаях и решения проблем - в других. Имеются примеры, где эти «инструменты» уже успешно внедрены, а где-то они пока находятся в стадии утвержденных проектов.

Благодаря новым градостроительным технологиям, освоенным новаторскими командами, появились такие концепции, как «думающий город», «креативный город», «умный город» (smart city), «ресурсосберегающий город», «город-сад» и т. п. Большинство экспертов сходятся во мнении, что эта междисциплинарная сфера может составить основу для шестого технологического уклада, наряду с нано- и биотехнологиями, робототехникой и технологиями виртуальной реальности [Щукин, 2011]. Инновации в этой области оперативно принимаются проектировщиками, архитекторами, строителями. Проявляя инициативу, они меняют спрос и устанавливают новые целевые ориентиры, представляя образы привлекательных урбанизированных пространств посредством 3D-моделирования. По сути, архитекторы и планировщики выступают движущей силой, агентами перемен и новых сверхтехнологичных стандартов в градостроительстве. А. Скотт дал удачное определение большим городам как «креативным полям», синтезирующим культурную и экономическую жизнь [Scott, 2006]. Эту идею поддерживает Р. Флорида, выразивший убеждение, что в глобальной конкуренции выигрывают города, способные продуцировать новые рыночные идеи [Флорида, 2002]. Созидательная способность городов зависит от концентрации творческих людей на их территории. В версии Р. Флориды, мировое креативное лидерство принадлежит таким городам, как Сан-Франциско, Остин, Сан-Диего, Бостон и Сиэтл (США). Схожей точки зрения придерживается и Р. Бэйли, выделяющий в качестве основной характеристики «креативного города» постоянное наращивание человеческого и социального капитала [Бэйли, 2011].

Сегодня города обретают новое «лицо» благодаря множеству создаваемых в подобном ключе новых тенденций и образов. Курс на креативность и инновации предоставляет множество преимуществ для тех мегаполисов, которые придерживаются его при формировании своих стратегий. Достигнув с его помощью, прежде всего, высокой конкурентоспособности, такие города становятся первопроходцами в создании совершенно новых реальностей. Примером может служить концепция «smart city», предполагающая внедрение инноваций во всех сферах жизнедеятельности города на основе информационно-коммуникационных сетей и технологий. Идея «умных» городов подразумевает тотальное развитие инноваций, насыщая высокой концентрацией интеллекта следующие направления [Steinert et al., 2011]:

- управление (эффективное взаимодействие органов власти разных уровней, система быстрого реагирования на нужды населения, повышение качества государственных услуг за счет введения систем электронного правительства и т. п.);

- население (новые образовательные технологии, обеспечивающие равный доступ к знаниям для всех слоев общества);

- среда обитания (новые технологии энергосбережения);

- мобильность (интеллектуальные транспортные системы);

- экономика (расширение возможностей для бизнеса, прежде всего за счет разных форм электронной торговли);

- качество жизни (высококачественное здравоохранение, социальное обслуживание и автоматизация зданий).

Существуют многочисленные примеры практик, в которые существенный вклад внесли ИКТ. Так, за счет «умного» энергосбережения удалось сократить количество выбросов парниковых газов в атмосферу. В жилищно-коммунальном секторе технологии «умного дома» предоставляют возможность самостоятельно настраивать режим энергопотребления бытовой техники: в отсутствие жильцов многие приборы автоматически обесточиваются. Интеллектуальные логистические системы предполагают использование смешанного транспортного режима, что позволяет оптимизировать перевозки грузов и т. п. [Steinert et al., 2011]. По оценкам The Climate Group [2008], использование подобных технологий позволит к 2020 г. снизить выбросы парниковых газов в общемировом масштабе на 15\%.

Пример наиболее удачной практики реализации концепции «умного города» представила компания IBM в американском городе Чесапик (Chesapeake), штат Вирджиния, с населением свыше 200 тыс. жителей. Партнерство с IBM - часть генерального плана развития города. Компания разработала интеллектуальные городские системы, которые расширяют возможности муниципальных служб, отвечающих за организацию общественных работ, предоставление коммунальных услуг, обеспечение общественной безопасности и содержание рекреационных зон. Использование подобных технологий позволяет повысить качество услуг во всех сферах жизни города - от размещения дорожных знаков, обслуживания систем водоснабжения до организации работы управления пожарной охраны и полицейского управления. Как следствие, улучшится качество жизни населения. Система постоянного сбора и анализа данных позволяет транспортным, коммунальным и другим городским службам оперативно обмениваться информацией и реагировать на резкие изменения ситуации, в частности регулировать работу муниципального транспорта. В реализацию программы «интеллектуализации» городской инфраструктуры ежегодно инвестируется более 
1.2 млрд долл. Интеллектуальные системы управления инфраструктурой Чесапика основаны на программном обеспечении IBM Махіто. Представление в цифровом виде информации о ключевых системах города позволило властям собирать данные об эффективности процессов (например, очистки сточных вод), которые ранее невозможно было измерить и оценить. Ожидается, что это, в свою очередь, приведет к принятию более обоснованных решений руководителями и разумному планированию.

«Умные» города стремятся обеспечить высокий уровень жизни, сочетая экономическую изобретательность со стабильностью, стимулируя передачу полномочий местным сообществам и повышая стандарты обслуживания. Высокое качество жизни усиливает экономическую и социальную динамику и используется как инструмент в конкурентной борьбе с другими городами. Примечательно, что к категории «smart cities» пока не относятся мегагорода [Landry, 2008].

Другой пример - масштабный проект «НьюСонгдо» в Корее. Он предполагает строительство с нуля целого города, инновационного не только по архитектуре, но и по технологической начинке, которая и должна сформировать всю городскую среду. В версии корейцев этот проект носит название - «ubiquitous city», или «U-City». Но, по смыслу, это все тот же «умный» город: основные информационные системы и сенсорные датчики изначально встраиваются во все дома, улицы, автомобили, офисы и медицинские учреждения, и полностью интегрируются между собой. Предполагается, что Нью-Сонгдо станет одним из самых мощных деловых центров Азии, создав полигон для «полностью прозрачной электронной жизни» [Cisco, 2007]. K тому же ему отводится роль опытного полигона, население которого проверит жизнеспособность подобных новаций. «Электронный» город будет объявлен свободной экономической зоной, с налоговыми стимулами для развития бизнеса. Проект способствует воплощению концепции, основанной на рациональном управлении, формировании новых экосистем, государственно-частном партнерстве и внедрении «умных» коммуникаций. По мнению В. Элфринка, руководителя отдела глобализации компании Cisco, данная инициатива станет ярким примером «умного» города будущего, в котором воплощаются последние технологические достижения.

Подобные комплексные «умные» системы требуют особенно прогрессивного мышления городских властей. Тем не менее, концепцию «умных» городов легче воплотить на уровне отдельных городских направлений и аспектов, что уже и осуществляется. В табл. 1 систематизированы некоторые примеры внедрения интеллектуальных систем для решения текущих проблем в ключевых аспектах городской жизнедеятельности.

Суммируя сказанное выше о новой концепции развития городов, можно предположить, что к ее реализации наиболее близки города, которые раньше других осознали смену парадигмы и разработали сценарий перехода в новое качество. О них - в следующем разделе.

\section{Табл. 1. Примеры внедрения "умных» систем для решения текущих проблем в ключевых аспектах городской жизнедеятельности}

\section{Проблемы}

Обработка и анализ колоссальных потоков информации для контроля ситуации в городе

Ограниченный доступ населения к информации о сфере здравоохранения, образования, ЖКХ

Заторы на дорогах, наносящие ущерб городскому бюджету

Отсутствие развитой инфраструктуры связи, низкая скорость и ограниченная зона доступа в Интернет

Низкое качество воды, более 50\% городского водотока загрязнено

Административные барьеры и пробелы в системе регулирования сдерживают развитие бизнеса

Угроза энергетической безопасности

\section{Задачи}

Снижение преступности и оперативное реагирование на угрозы городской безопасности на основании анализа информации в режиме реального времени

Внедрение передовых аналитических инструментов для обработки колоссальных массивов информации в целях повышения эффективности указанных секторов

Устранение заторов путем введения интегрированных транспортных систем и увеличения количества пересадочных узлов

Создание единой скоростной сети, доступной для всех

Создание интегральной системы водного мониторинга, предоставляющей данные о водопользовании на разных уровнях

У становление системы наивысших стандартов ведения бизнеса и повышения его эффективности

Налаживание системы обратных связей между производителями и потребителями энергии в целях эффективного энергопользования

\section{Достигнутые результаты}

Чикаго (США). Новая система городской безопасности позволяет при помощи видеомониторинга в реальном времени более оперативно реагировать на чрезвычайные ситуации

Копенгаген (Дания). Благодаря оперативному доступу врачей к медицинским картам стала возможной точная диагностика болезней

Стокгольм (Швеция). Динамическая шкала тарифов для разных категорий автотранспорта позволила сократить внутригородской трафик на $25 \%$ и снизить выбросы на 14\%, при этом доходы в городской бюджет увеличились на $6 \%$

Нью-Сонгдо (Корея). Интегрированная система баз данных по различным секторам обеспечивает широкий спектр дополнительных новых услуг

Галвей (Ирландия). Системы водного мониторинга, управления качеством воды и прогнозирования водных проблем предоставляют оперативную информацию всем заинтересованным сторонам

Дубай (ОАЭ). Система «одного окна» интегрирует около ста видов услуг

Сиэтл (США). «Умная» энергосистема обеспечивает снижение нагрузки на электросети на величину до $15 \%$, а плата за электроэнергию в среднем сократилась на $10 \%$ 


\section{Города-«стратеги»}

Данная категория городов представляет для нас интерес в связи с тем, что они проявляют столь необходимую для эффективного развития в современном контексте дальновидность, просчитывая его изменчивость и соответствующим образом адаптируясь, в стремлении достичь сбалансированного развития. Относящиеся к ней города обладают стратегическим прицелом, что обусловлено наличием критической массы новаторски мыслящих, впередсмотрящих городских команд. Новая философия распространяется уже не столько на уровне отдельных проектов, сколько в масштабах города в целом. Детальный анализ стратегий развития таких городов показывает, что универсального рецепта для перехода в иное качество не существует. Тем не менее, во всех случаях решающую роль сыграла комбинация новых инструментов политики, наличие человеческого и культурно-исторического капитала.

Наиболее ярким примером города, осваивающего новые концепции, на наш взгляд, является Ванкувер, который в последние годы неизменно занимает верхние строчки мировых рейтингов городов с наивысшим качеством жизни. Третий по величине город Канады, включая пригороды, насчитывает более 2 млн чел. Его население отличается значительной степенью мультикультурности - свыше 20 национальностей. Ванкувер обладает крупнейшим в стране и наиболее диверсифицированным портом, здесь располагаются штаб-квартиры крупных компаний, относящихся как к традиционным, так и новым секторам. Удачное во многих отношениях расположение делает его привлекательным экономическим центром, стимулируя большой приток туристов и иммигрантов. В нем сформирована благоприятная среда для инноваций (в частности, в сфере экологии), обеспечения равного доступа к ресурсам и инклюзивного развития. Среди всех крупных городов Северной Америки на долю Ванкувера приходится наименьший объем выбросов парниковых газов в атмосферу. Благодаря перечисленным факторам в начале 2011 г., по оценкам экспертов сразу двух ведущих международных агентств - Economist Intelligence Unit и ЮНЕСКО, Ванкувер подтвердил звание «лучшего города Земли».

Термин «впередсмотрящий» как нельзя точнее характеризует этот город: здесь своевременно выявляют грядущие тренды, с участием всех заинтересованных сторон разрабатывают согласованное видение будущего и последовательно его реализуют. Администрация практикует политику интегрального планирования городской среды на основе следующих принципов:

- охрана здоровья;

- энергоэффективность;

- равный доступ к ресурсам;

- качество окружающей среды.

Основной курс политики ориентирован на создание устойчивых городских сообществ, что предполагает формирование ряда районов, самостоятельно снабжающих себя всеми необходимыми ресурсами [Бэйли, 2011]. Предполагается, что каждый район будет оснащен всей необходимой инфраструктурой, обеспечивающей комфортную жизнедеятельность, включая работу, жилье и отдых. Планировка кварталов следует созидательной логике: улица должна не разделять дома, а стать местом встреч и обмена идеями. К настоящему времени реализован пилотный проект подобного квартала - на месте бывшей промзоны в районе Фалс-Крик (False Creek). Сто тысяч человек уже живут в «новой реальности», где обеспечены культурное многообразие, высокое качество жизни, сохранено историческое наследие, воссоздан естественный природный ландшафт, чередующийся со среднеэтажной застройкой. Жилые здания очень гармонично сочетают социальное жилье с элитными квартирами. Соединяющие их переходы и внутренние дворики призваны сближать жильцов. Работает принцип нулевого энергопотребления предусмотрена генерация вторичной энергии из отходов жизнедеятельности, следовательно, появляется возможность при необходимости снабжать излишками накопленной электрической и тепловой энергии другие здания. Энергоэффективность зданий предполагает ответственное использование энергоресурсов всеми жителями. Водоснабжение во многом обеспечивается за счет максимально эффективного сбора дождевой воды. Крыши домов усажены деревьями, здесь можно выращивать разные сельскохозяйственные культуры, что снимает необходимость доставки продуктов первой необходимости издалека и способствует общему снижению атмосферных выбросов.

C 2009 г. реализуется программа The Greenest City, преследующая амбициозную цель - превратить Ванкувер к 2020 г. в самый «зеленый» город мира [Vancouver 2020]. В ней установлены десять долгосрочных целей по трем направлениям: «зеленая» экономика; экологическая ответственность; здоровье населения. Каждая из них дополнена конкретными показателями, достижение которых запланировано к 2020 г. Это своеобразная контрольная отметка на «дорожной карте» долгосрочного развития. Поставленные цели требуют стратегического перераспределения приоритетов города, его ресурсов, корректировки рабочих программ и планов. Для достижения поставленных задач в Ванкувере усиливается вектор на сотрудничество городских властей с ведущими партнерскими организациями и общественностью. Общие цели стратегии и конкретизирующие их показатели представлены в табл. 2.

Показательно, что даже Нью-Йорк, магнетизм которого привычно ассоциируется с небоскребами Манхэттена, в новой стратегии развития берет курс на «greater and greener».

Общепризнанным образцом успешной реализации стратегического планирования в США является город Шарлотт (Северная Каролина). Четкую стратегическую направленность и более полную информированность для принятия решений в управлении городом здесь обеспечили комбинация метода дорожных карт и сбалансированной системы показателей в муниципальном управлении. В «Дорожной 


\section{Табл. 2. Долгосрочные цели Ванкувера на пути к статусу «самого зеленого города» в мире}

Категория

Долгосрочная цель

«Зеленая» экономика

«Зеленый» экономический капитал

Управление климатическими изменениями

«Зеленые» здания
Обретение статуса ведущего мирового центра «зеленого» бизнеса

Обеспечение независимости города от ископаемых источников энергии

Превращение в мировой центр по проектированию и строительству «зеленых» зданий

Целевой показатель к 2020 г.

Создание 20 тыс. новых рабочих мест в секторах «зеленого» бизнеса

Сокращение выбросов парниковых газов на треть по сравнению с уровнем 2007 г.

Строительство новых зданий на «безуглеродной» основе

Повышение энергоэффективности существующих зданий на $20 \%$

\section{Экологическая ответственность}

\begin{tabular}{|c|c|c|}
\hline $\begin{array}{l}\text { «Экологичная» мобиль- } \\
\text { ность }\end{array}$ & $\begin{array}{l}\text { Пешие прогулки, велосипедное движение и } \\
\text { общественный транспорт становятся пред- } \\
\text { почтительными способами перемещения }\end{array}$ & $\begin{array}{l}\text { Пешие прогулки, велосипедное движение и } \\
\text { общественный транспорт обеспечивают более } \\
\text { половины общего объема перемещений }\end{array}$ \\
\hline $\begin{array}{l}\text { Безотходная жизнедея- } \\
\text { тельность }\end{array}$ & $\begin{array}{l}\text { Обеспечение полностью замкнутого цикла } \\
\text { потребления }\end{array}$ & $\begin{array}{l}\text { Снижение объема твердых бытовых отходов, } \\
\text { поступающих на свалку или мусоросжигатель- } \\
\text { ный завод, на треть }\end{array}$ \\
\hline $\begin{array}{l}\text { Повышение доступ- } \\
\text { ности природных объ- } \\
\text { ектов }\end{array}$ & $\begin{array}{l}\text { Обеспечение равного доступа жителей к } \\
\text { зеленым зонам }\end{array}$ & $\begin{array}{l}\text { Обеспечение проживания каждого жителя в } \\
\text { максимальной близости (не более } 300 \text { м) от } \\
\text { объектов рекреационной зоны } \\
\text { Высадка } 150 \text { тыс. новых зеленых насаждений }\end{array}$ \\
\hline $\begin{array}{l}\text { Уменьшение загрязне-- } \\
\text { ния окружающей среды }\end{array}$ & $\begin{array}{l}\text { Достижение наименьшего объема загрязне- } \\
\text { ния среди крупнейших городов мира }\end{array}$ & Снижение экологической нагрузки на треть \\
\hline \multicolumn{3}{|c|}{ Здоровье населения } \\
\hline Чистая вода & $\begin{array}{l}\text { Достижение самого высокого качества } \\
\text { питьевой воды среди мегаполисов }\end{array}$ & $\begin{array}{l}\text { Обеспечение жесткого соответствия качества } \\
\text { воды стандартам Всемирной организации здра- } \\
\text { воохранения, которые выше национальных } \\
\text { Сокращение водопотребления на треть }\end{array}$ \\
\hline Чистый воздух & $\begin{array}{l}\text { Обладание самым чистым воздухом среди } \\
\text { всех крупных городов мира }\end{array}$ & $\begin{array}{l}\text { Обеспечение неизменного соответствия каче- } \\
\text { ства воздуха требованиям Всемирной организа- } \\
\text { ции здравоохранения }\end{array}$ \\
\hline Продовольствие & $\begin{array}{l}\text { Достижение мирового лидерства в продо- } \\
\text { вольственном обеспечении }\end{array}$ & $\begin{array}{l}\text { Снижение экологической нагрузки пищевого } \\
\text { сектора на треть }\end{array}$ \\
\hline
\end{tabular}

Источник: [Vancouver City Council, 2009].

карте» сформулированы 21 цель развития, распределенные по пяти приоритетным сферам деятельности: общественная безопасность, внутригородские общины, транспорт, экономическое развитие и реструктуризация управления.

До разработки сбалансированной системы городские власти оперировали примерно 900 показателями по 13 основным подразделениям. После внедрения новых инструментов их количество уменьшилось примерно до 380. Помимо повышения эффективности управления, в том числе и бюджетного планирования, данная система фокусирует внимание на стратегии на всех уровнях организации, помогает достигать консенсуса в процессе формулировки целей, разработки критериев и инициатив. По мнению городских властей, сбалансированная система показателей становится движущей силой городских трансформаций. С помощью этих инструментов городские власти регулярно проводят оценку деятельности, оперативно корректируя планы развития. Подобная практика вошла в перечень лучших управленческих методов, составленный Международной ассоциацией городского и окружного управления в 2001 г. [Берч и др., 2010].

Приведенные примеры - яркая иллюстрация потенциала новых управленческих концепций. Очевидно, что далеко не все города смогут «войти» в эту трансформационную модель по разным объективным причинам, включая дефицит критической массы материальных и неосязаемых ресурсов, а также ментальную неготовность к самой постановке подобной задачи. Анализ практик городов-«стратегов» позволил выявить типичный набор качеств, способствовавших преодолению потенциальных серьезных структурных кризисов [Anderson, 1987; Hall, 1995, 1998]:

- наличие глубоких и оригинальных знаний в комбинации с определенным набором умений и навыков;

- прочная финансовая основа, предоставляющая поле для смелых экспериментов;

- умение согласовать интересы всех сторон, преодолев дисбаланс возможностей и потребностей;

- устранение неопределенности перспектив развития научно-технической и культурной сфер;

- условия для эффективной коммуникации и взаимодействия;

- диверсифицированные возможности развития;

- междисциплинарность и динамичная синергия.

Необходимость стратегического планирования и инноваций осознана в большинстве стран и ведущих городов мира. В зависимости от склонности городских управленцев к подобным видам деятель ности планы перспективного развития городов будут способствовать либо их преуспеванию, либо постепенной утрате имеющегося потенциала. Однако переход на инновационную модель не всегда связан с предусмотрительностью. Отдельным городам пришлось совершать подобную трансформацию 
с целью преодоления наступившего упадка базовых отраслей, т. е. действовать по реактивной, а не превентивной схеме. Они представляют следующую категорию рассматриваемых нами городов.

\section{Города-«новаторы»: уроки выхода из «кризиса жанра»}

Выделяя эту категорию городов, мы исходили не из их размеров, а из новаторской логики поведения. Столкнувшись однажды с потерей основных источников жизнеобеспечения городской экономики, благодаря изобретательности, нестандартному мышлению, управленческие команды этих городов сумели превратить минусы в плюсы, таким образом обратив депрессивное состояние в источник новых возможностей. Возрождение подобных городов стало результатом решительных действий и способности гибко менять вектор развития. Как правило, во всех случаях кризис был вызван утратой актуальности базовых экономических секторов, которые «пи тали» город. Следовательно, возникала потребность в структурной перестройке всего городского хозяйства и формировании новых источников экономи ческого роста.

Как показывает исторический опыт, ни одно му городу не удавалось удерживать новаторский дух в течение достаточно долгого периода времени. Так, в разные времена в сфере культуры роль мирового центра принадлежала Афинам (V в. до н.э.), Флоренции (XV в.) и Вене (XVIII в.); а в сфере техники - Манчестеру (XVIII в.), Берлину (XIX в.) и Детройту (XXв.). Тем не менее, во многих случаях именно новаторское мышление имеет решающее значение для успешного преодоления депрессивного состояния городской экономики. Подобная модель развития не нова, но мало практикуется по причине сложности перестройки систем мышления и отсутствия специализированных компетенций. Гораздо легче объяснить причины стагнации городов отсут ствием инвестиций, чем применить адаптивность, гибкость и попытаться найти новые решения, вый дя за рамки привычных шаблонов. Как показывает практика, здесь нет универсальных рецептов. Но в каждом случае имели место стратегическое мышле ние и уникальные технологические решения. Люди и организации, способствовавшие трансформирующему переходу к новым источникам жизнедеятельности городов, обладали определенным набором качеств: широким кругозором, готовностью к риску, сосредоточенностью на долговременных целях, чет ким пониманием стратегии, способностью работать, опираясь на местную специфику, и находить сильные стороны в очевидных недостатках, желанием слушать и учиться.

Помимо наличия перечисленных факторов ключевую роль сыграла синергетическая модель взаимоотношений между населением и городской администрацией. Перечень городов-феноменов, прошедших через тяжелый кризис, достаточно обширен: Мемфис, Детройт, Манчестер, Балтимор, Питтсбург, Кливленд, Барселона, Бильбао, Сиэтл, Сидней, Хельсинки, Роттердам, Дублин, Куритиба,
Карлсруэ, Страсбург и др. Рассмотрим некоторые из них подробнее.

\section{Тилбург (Нидерланды)}

В свое время кризис градообразующей промышленности стимулировал появление революционной идеи - разработку уникальной системы городского управления по образцу холдинговой компании. Подразделения городской администрации стали работать как коммерческие центры, производящие по строго определенной номенклатуре городские услуги и иные «продукты». Городской совет оценивает эту «продукцию», ее объем и качество, разрабатывая соответствующие стандарты. Администрация отвечает за оказание услуг с минимизацией издержек согласно инструкциям, критериям и стандартам, задаваемым общей стратегией. Департаменты заключают контракты с городскими властями и сообщают членам совета о ходе работ и отклонениях от плана посредством прозрачной информационной системы. При этом обеспечивается необходимый баланс между техническими и финансовыми возможностями города, с одной стороны, и потребностями его жителей - с другой. Он достигается в результате консультаций с жителями города, чьи мнения ложатся в основу плана и проектов стандартизации качества услуг. Основная концепция данной системы планирования заключается в достижении взаимного согласия по поводу стандартов качества. Большая часть городских служб теперь нуждаются лишь в адекватной технической поддержке, их функции уже не оспариваются. Результат - начиная с конца 1980-х гг. в бюджете города имеется профицит, который инвестируется в его развитие.

\section{Хаддерсфилд (Великобритания)}

Задача преобразования депрессивной территории решалась путем перепрофилирования старых промышленных площадок под развитие высоких технологий, формирование среды, где живут и работают предприимчивые жители и созданы все условия для поддержки и коммерциализации их идей. В частности, были построены гибриды жилых домов и офисных зданий, стиравшие барьер между жизнью на работе и вне ее, реализован экспериментальный проект «дома будущего». Новаторский подход к преобразованию города заключался в вовлечении широких кругов населения и формировании инновационной культуры. Эту идею удалось воплотить при помощи проекта «Вызов тысячелетия», состоявшего из серии инициатив по следующим направлениям: рост благосостояния, улучшение облика города, превращение его в здоровое и безопасное место, предоставление новых образовательных возможностей и создание позитивного имиджа города.

Сегодня в постоянном режиме работает «живой» форум горожан по разным темам, включая «Поиск будущего», реализуется ряд образовательных проектов по предпринимательству, сформирована связь между культурным и технологическим новаторством. Система поддержки инновационного микробизнеса оказывает содействие безработным, 
предложившим перспективную бизнес-идею, но не имеющим ресурсов для ее реализации. В рамках отдельных проектов устанавливаются партнерства между новаторами и инвесторами. В перспективе это должно обеспечить синергетический эффект и способствовать развитию новых видов деятельности, включая экологические и социальные инновации. Именно применение инновационного подхода позволило Хаддерсфилду приобрести статус крупного перспективного промышленного, спортивного и образовательного центра.

\section{Эмшер-парк (Рурская агломерация, Германия)}

Рур - одна из наиболее урбанизированных и индустриализированных европейских территорий, представляющая собой густонаселенную городскую агломерацию с населением 5.3 млн жителей. Территория являлась очагом интенсивного экономического и общественного развития во времена двух последних промышленных революций. В центре Рурской агломерации расположен Эмшерский район, занимающий территорию площадью 800 км²$^{2}$ На этой территории расположены 17 городов с общим населением 2 млн чел. Наследием эпохи индустриализации стали: загрязненный ландшафт, горы шлака, крайняя деградация окружающей среды. В последние десятилетия XX в. было ликвидировано более 600 тыс. рабочих мест и уровень безработицы (13\%) оказался самым высоким в Германии.

В преодолении кризиса делалась ставка на различные виды инноваций. Для этого был сформирован центр исследований и разработок, который изучал возможности возрождения территории и формировал сценарии их реализации. Проект предусматривал разнообразные составляющие: университетские исследования, разработку продуктов в коммерческих лабораториях, пилотные проекты по их внедрению в перепрофилированных заводских постройках и новых зданиях, построенных по экологическим принципам. Этому процессу содействовало ужесточение природоохранного законодательства. К концу 1990-х гг. более 50 тыс. чел. в районе Эмшера были приняты на работу в новую сферу - восстановительные и предупреждающие технологии. Благодаря государственной поддержке появилось множество новых компаний, которые взяли на вооружение передовые методы в области контроля качества и природоохранных технологий.

Специально созданный экспериментальный кластер охватывал 100 подобных проектов, преследовавших общую цель экономической реструктуризации и экологической реабилитации территории. Каждый проект обладал своей спецификой, тем не менее, вследствие их синергии результативность кластера оказалась выше, чем простой суммарный вклад отдельных компонентов.

Жизненно важную роль в планировании сыграли выявление культурной перспективы, использование нетрадиционных, креативных подходов к городскому и региональному развитию, признание невозможности единоличного формирования городскими властями нового облика города, наведение мостов между различными дисциплинами, институтами и подходами, свойственными государственному, частному и некоммерческому секторам. Другими словами, полной реализации городского потенциала способствовали новые формы сотрудничества, выходящие за рамки межведомственных отношений [Landry, 2008].

\section{Перемена мышления - предпосылка качественных стратегий}

Смена парадигмы в развитии городов диктует принципиально иные подходы к городской политике. Для формирования экономики города на основе инноваций, прежде всего, необходимо наличие определенной креативно-интеллектуальной среды. Несомненно, требуется преодолевать зашоренное мышление, которое не позволяет видеть картину в целом, осознать и «расшифровать» имеющие место тенденции. Управление городом никогда не являлось простой задачей. Тем более, сегодня, исходя из масштабов городов и неординарности происходящих в них процессов, требуется «высший пилотаж» в умении синтезировать разные направления, согласовывать интересы многочисленных социальных групп, экономических секторов и других субъектов.

В прежней логике развития город представлял собой набор разрозненных проектов. На сегодняшнем, более сложном этапе развития его требуется рассматривать как единый проект. Для того, чтобы город стал таковым, необходима критическая масса сильных лидеров-единомышленников, которая поднимает коллективное сознание и вдохновляет население на добровольное участие в создании и реализации видения гармоничного города [Лэндри, 2011].

Городские стратегии, основанные на коллективном формировании будущего, - явление сравнительно новое. Подобная практика зародилась в послевоенный период и обрела методологический аппарат в США, где использовалась для борьбы с обострившимся кризисом городов, находившихся под угрозой утечки капитала и отъезда образованных людей. Некоторые концепции с течением времени не теряют своей действенности. Так, создание вокруг городов защитных зеленых поясов, начавшееся сразу после Второй мировой войны в европейских странах, до сих пор воспринимается как актуальная идея.

Учитывая описанные выше масштабные проявления глобализации в развитии городов, можно говорить о сопоставимых с этими процессами последствиях, к которым приведет выбор городскими управленцами той или иной траектории развития. В подобных условиях старый понятийный аппарат и соответствующая логика в лучшем случае заставляют вновь и вновь фокусироваться на «вчерашних» проблемах, а не на «завтрашних» возможностях. Следовательно, наличие уникальных стратегий, учитывающих новый вектор развития, для многих городов - вопрос, как минимум, выживания. Возможность разработки стратегий 
выше у крупных экономических центров, которые пользуются значительной финансовой и юридической самостоятельностью [IBM, 2009a]. Менее масштабные по численности населения и статусу города, испытывая зависимость от политики федерального центра, такой возможности часто не имеют. Исходя из того, что в задачи городской администрации входят поддержка баланса между различными группами интересов путем сложного управления процессами жизнедеятельности (выдача разрешений, лицензий, принятие постановлений и т. п.), отсутствие грамотной, постоянно корректирующейся стратегии - серьезная проблема, которая затрудняет адаптацию сложных регулирующих систем к непрерывно меняющимся условиям [Landry, 2008].

В основе нового подхода к формированию стратегии лежит принцип инклюзивности, т. е. вовлечения всех ключевых игроков - от городских властей, бизнеса, науки, образовательного сектора до широких общественных кругов. Традиционно считалось, что решение городских проблем не входит в сферу ответственности бизнеса или населения, а является исключительно прерогативой муниципальных властей или правительства. Вместе с тем, растущее осознание неспособности муниципального, частного и некоммерческого секторов в одиночку противостоять новым вызовам создало предпосылки для формирования партнерств с целью объединения ресурсов и усилий. Большинство ведущих урбанистов мира высказываются за перенос принципов бизнеспланирования, практикуемых успешными компаниями, на разработку стратегий городского развития. Тилбургская модель, рассмотренная выше, - наи более яркий результат подобного подхода.

С формированием городских стратегий связана серьезная проблема, распространенная в мировом масштабе. Ведущие урбанистические школы, изучая современные и будущие усорвия развития городов, выработали эффективный инструментарий для решения проблем и динамичного прогресса. Сложность в том, что лежащий в его основе подход - междисциплинарный - для основной массы городских чиновников является достаточно революционным. Освоение его происходит не столь оперативно, как того требует жизнь, в силу ментальных особенностей, отсутствия специальных образовательных программ и недостатка времени для этого. Поэтому на практике стратегическое планирование достаточно сложно реализовать в политике городского развития. Как правило, вышеуказанный барьер влечет за собой ряд других ограничений; принимаются непродуманные решения, часто базирующиеся на стандартных финансовых подсчетах, не оставляющих места интуиции и поиску неявных возможностей. Умение выявить скрытые потенциалы относится к портфелю новых продуктивных компетенций, которые необходимы для получения качественно новых результатов в столь сложной области, как развитие города. Этот портфель также включает сочетание междисциплинарности и комплексности, гибкость, сетевой подход, оригинальность и склонность к экспериментам, умение критически оценивать ситуацию и задавать правильные вопросы, недетерминированное мышление, знание специфики различных культур [Bianchini, Ghilardi, 1997].

Рождение новых урбанистических концепций начинается на стыке различных дисциплин и тех дополнительных возможностей, которые возникают в результате их синергии. До недавнего времени базовыми дисциплинами для развития городов считались лишь градостроительство, архитектура и землепользование. Затем к этому блоку добавились инженерное искусство, геодезия, топография, оценка недвижимости, строительство и проектный менеджмент.

Мультидисциплинарность заключается в выработке практических решений путем синтеза знаний из перечисленных и других сфер. Решением, позволяющим преодолеть фактор узости мышления городских менеджеров, может быть создание коллектива, качества и компетенции членов которого комплементарны. Специалисты с фрагментарным мышлением должны «дополняться» теми, кто изначально способен увидеть целостную картину. Чем глубже проанализирована проблема, тем изобретательнее может быть подход к решению. Многоуровневое рассмотрение проблем с точки зрения широкого спектра дисциплин позволяет увидеть мельчайшие ошибки, допущенные в прошлом.

При междисциплинарном планировании различные сферы рассматриваются одновременно, накопленные в них знания переплетаются, а в узлах пересечения рождаются новые идеи. Подобная синергия обеспечивает обогащение каждой из дисциплин частного характера. Сетевой анализ помогает выявить скрытые внутренние взаимосвязи между природной, социальной, культурной, политической и экономической составляющими урбанизированной среды, что способствует возникновению инновационной модели городского развития [Лэндри, 2011].

Инвестирование в развитие человеческого капитала должно быть сбалансировано с вложениями в материальный капитал. Другими словами, процесс трансформации должен проходить без отрыва от практики, подобно реконструкции предприятия, при которой должно сохраняться его бесперебойное функционирование.

Сдерживающим фактором в реализации инновационного потенциала является и чрезмерная регламентированность различных сфер деятельности. Как правило, ее стараются обходить, изобретая новые, более эффективные формы организации работы. В связи с этим вводятся конкурентные принципы в деятельность самой администрации, создаются межведомственные рабочие группы, устанавливаются государственно-частные партнерства. В большинстве случаев городские власти разрабатывают скорее формальные стратегии, чем работающие. В результате вместо динамичного развития город вязнет в проблемах.

Превентивный подход позволил бы сформировать дальновидную политику и предотвращать 
проблемы до их перехода в острую фазу. Но городские администрации в большинстве случаев предпочитают ориентироваться на быстрое достижение наглядных результатов, игнорируя долгосрочные цели. Между тем, чрезмерная занятость текущими проблемами, не оставляющая времени на стратегическое планирование, как раз и объясняется изначальным отсутствием стратегического фокуса [Landry, 2008].

Как было отмечено выше, еще одной доминантой новых концепций является переход от стратегии конкурентной борьбы за экономический рост к обеспечению высокого качества городской жизни, что позволяет решить задачу привлечения и удержания человеческого капитала. Набор необходимых условий включает широкий спектр культурных и социальных факторов, отвечающих самым высоким стандартам. Городская среда должна создавать возможности для эффективного сосуществования, диалога и сетевого взаимодействия представителей разных сообществ.

Суммируя сказанное, сформулируем требования к современным стратегиям городского планирования:

- одновременное наращивание стоимости экономических активов и высококвалифицированных человеческих ресурсов во всех сферах;

- учет личностных стратегий жителей города;

- приспособление процессов экономического развития и формирования благосостояния к потребностям городской среды;

- сценарное моделирование будущих процессов развития городской инфраструктуры;

- создание системы общественной поддержки и контроля;

- формирование культуры здорового образа жизни;

- создание уникальной притягательной атмосферы; кластеризация городского пространства;

- интегрирование этнических элементов в городской ландшафт;

- устремленность в будущее.

K настоящему времени подобные стратегии уже продемонстрировали свою эффективность на практике. Их результатами стали описанные выше «умные», «экологичные» города и другие сходные концепции.

\section{Новые инструменты городской политики}

Реализация новых концепций в развитии городов требует применения соответствующих инструментов. Остановимся подробнее на некоторых из них.

\section{Городские департаменты исследований и разработок}

Появление подобных структур при городских администрациях стало следствием внедрения корпоративной модели в развитие города, и они, как представляется, могли бы стать эффективным инструментом в выработке оптимальных решений для каждого конкретного города. Опыт Рурского региона в Германии, рассмотренный выше, - наглядная иллюстрация подобного подхода. Отдел исследований и разработок часто ассоциируют с департаментом экономического развития, тем не менее, их функции различаются. Первый работает как компас, анализируя контекст, возможности и угрозы, реагируя соответственно обстоятельствам; опирается на базы лучшей практики городского развития. Второй может способствовать лишь эволюции деятельности, не выходящей за рамки текущей промышленноэкономической политики.

\section{Базы данных}

Наличие баз данных по лучшим и провальным практикам - другой ключевой инструмент, поскольку он содействует генерации новых идей, мотивации к инновационным подходам и предостерегает от неверных шагов. Сравнительная оценка инновационных практик позволяет сократить процесс обучения, снизить расходы на исследования и разработки, сэкономить на стоимости экспериментальных и пилотных проектов.

При сборе информации необходимо придерживаться структурированного опережающего подхода, который позволяет тестировать, оценивать и подвергать мониторингу все «истории». Анализ лучших практик, по своей сути, предполагает не абстрактное ранжирование, а непрерывное обучение.

Базы лучшей практики задают городским властям ориентиры для осмысления проблем, обогащая стратегическое планирование в следующих формах:

- Кооперация. Налаживание связей с городом носителем лучшей практики в определенной сфере с целью чему-то у него научиться.

- Конкуренция. Выявление уникального преимущества города-конкурента и создание на его основе новой «зашифрованной» разработки.

- Compудничество. Обмен знаниями с другим городом-партнером путем активного совместного обучения.

- Внутренняя оцзенка. Выявление лучших управленческих практик внутри самой городской администрации и распространение этого опыта среди остальных сотрудников.

Кроме того, базы данных охватывают такие важные сферы, как регулирующие механизмы и системы стимулирования, которые используются для поощрения инноваций и сбалансированного развития городов. При этом рассматриваются, например, налоговые режимы, способствующие эффективному энергосбережению, стимулы бережного отноше ния бизнеса к окружающей природной и культурной среде и ряд других аспектов.

\section{Матрица городских инноваций и анализ их жизненного цикла}

С базами данных лучших и худших практик тесно связан следующий инструмент городской политики матрица инноваций, которая дает возможность городским управленцам оценить уровень инновационности проекта, служит инструментом самоконтроля. Она 


\begin{tabular}{|c|c|c|c|c|c|c|}
\hline 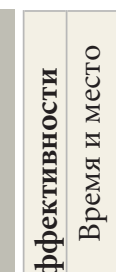 & 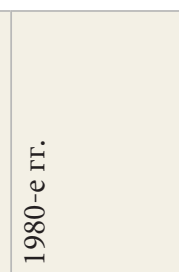 & 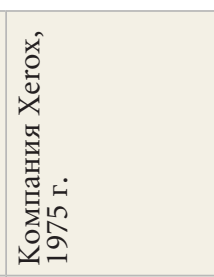 & 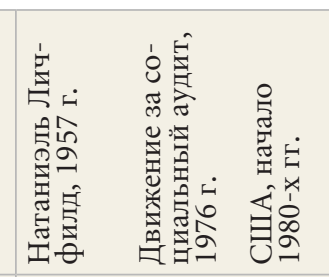 & 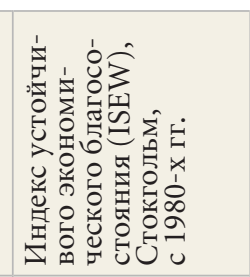 & 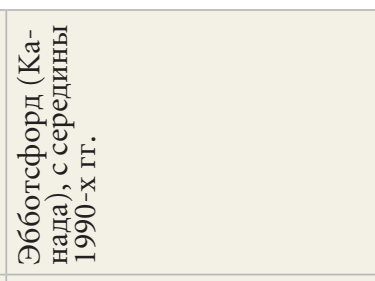 & 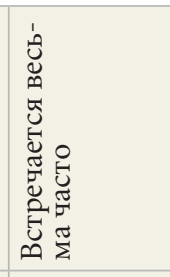 \\
\hline 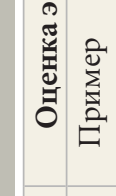 & 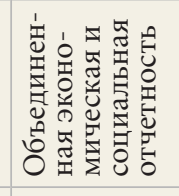 & 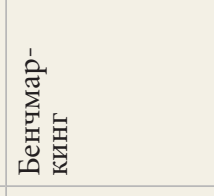 & 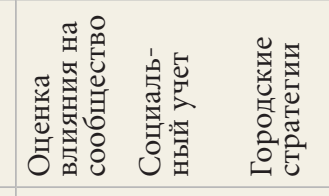 & 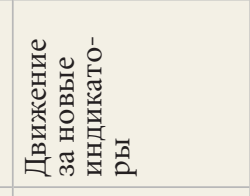 & 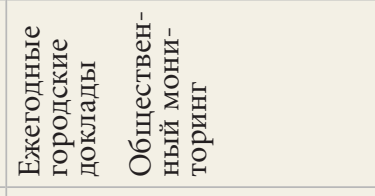 & 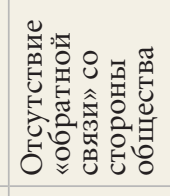 \\
\hline 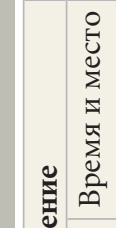 & 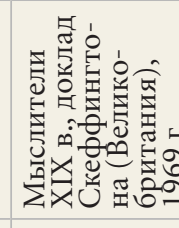 & 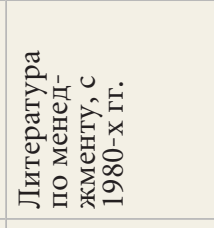 & 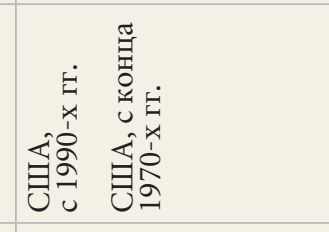 & 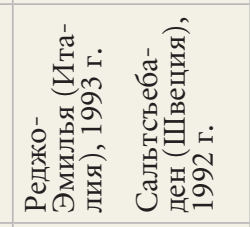 & 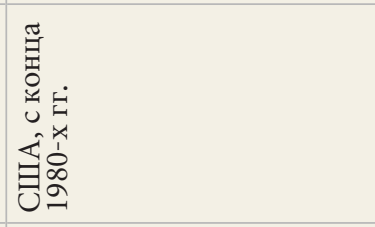 & 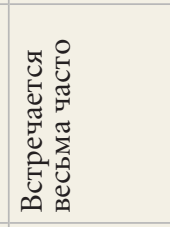 \\
\hline 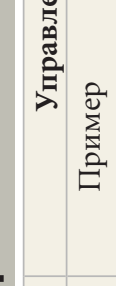 & 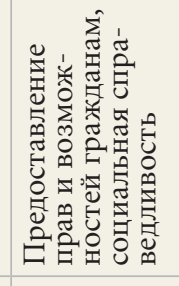 & 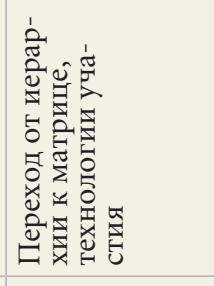 & 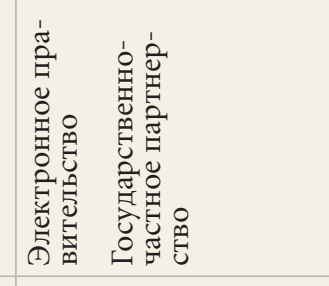 & 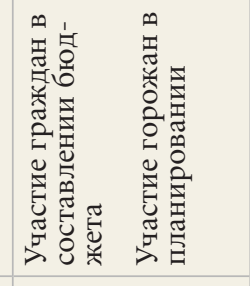 & 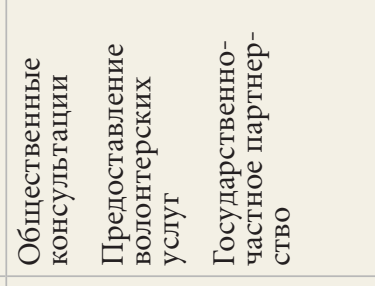 & 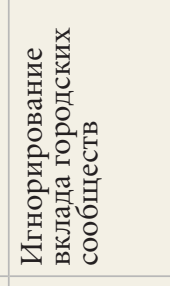 \\
\hline 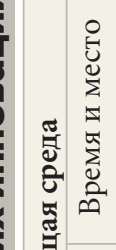 & 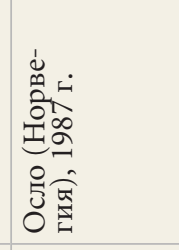 & 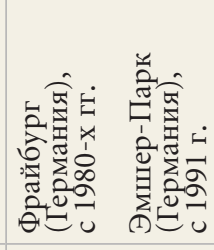 & 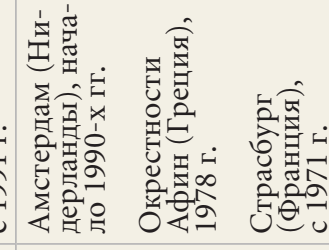 & 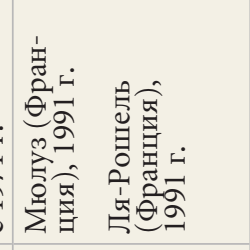 & 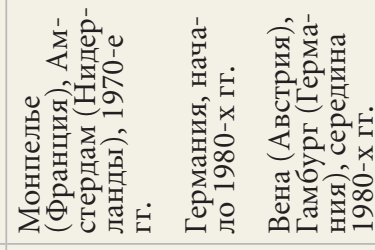 & 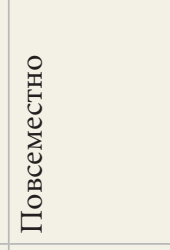 \\
\hline 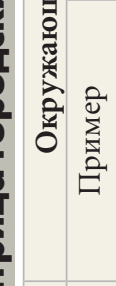 & 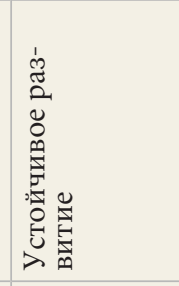 & 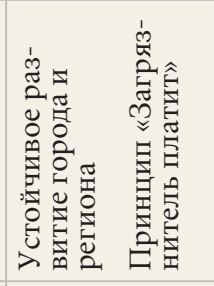 & 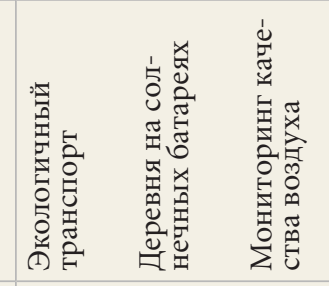 & 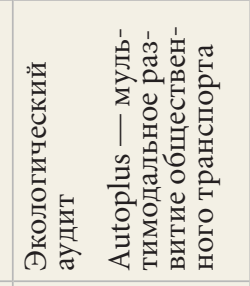 & 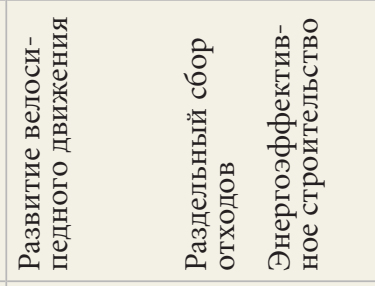 & 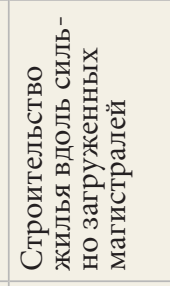 \\
\hline 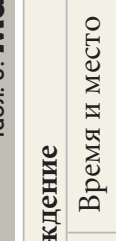 & 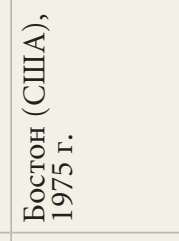 & 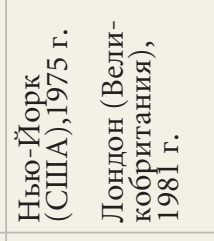 & 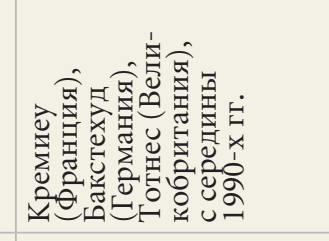 & 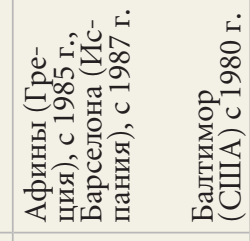 & 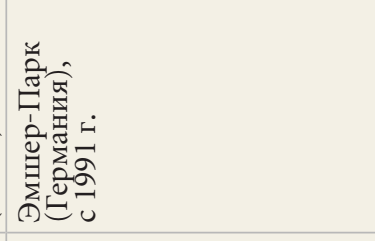 & 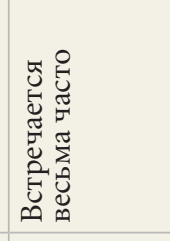 \\
\hline 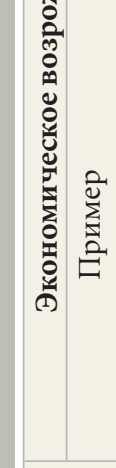 & 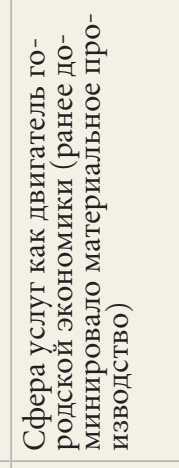 & 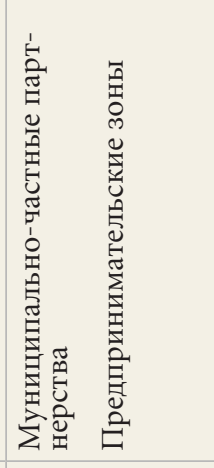 & 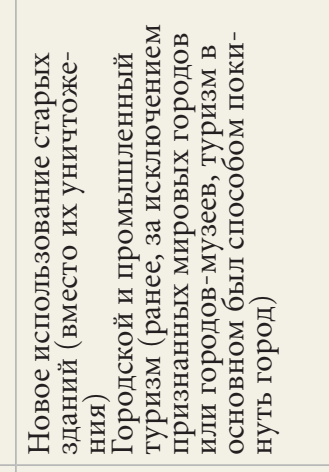 & 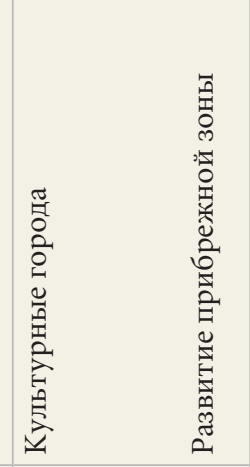 & 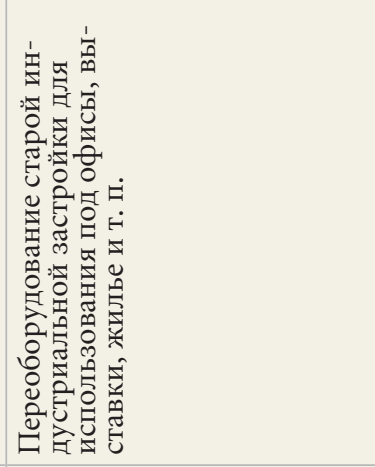 & 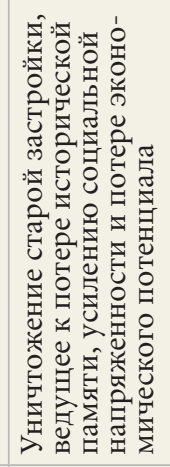 \\
\hline 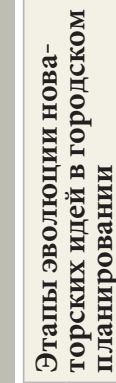 & 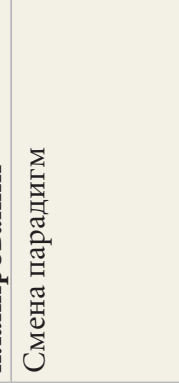 & 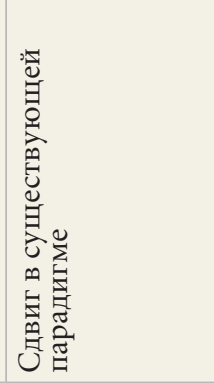 & 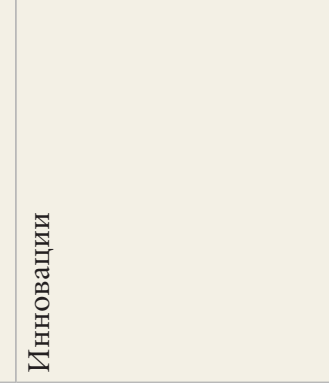 & 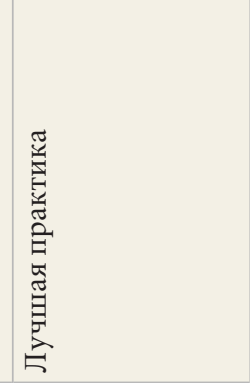 & 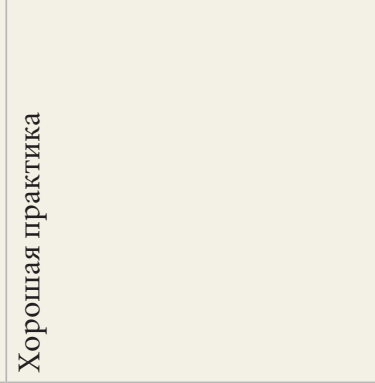 & 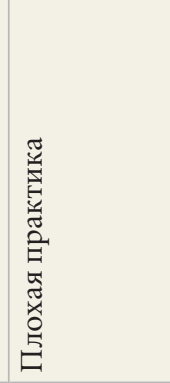 \\
\hline
\end{tabular}


помогает муниципальным властям оценить свои достижения, сопоставив их с примерами лучшей практики.

Структура матрицы городских инноваций с примерами приведена в табл. 3. Шесть категорий, образующих ее горизонтальную ось, составляют «жизненный цикл идеи». Процесс эволюционирует от верхней категории к нижней - новые идеи рождают соответствующую практику, которая становится общепринятой, но однажды, перестав отвечать изменившимся требованиям и задачам, должна быть пересмотрена.

Понимание жизненных циклов помогает оценить актуальность идеи, определить оптимальный момент внедрения инновации, сформировать бюджет на новые разработки, мониторинг, бенчмаркинг и т. п. Процесс корректировки должен быть постоянным.

Долгосрочная перспектива неизбежно предполагает кардинальные перемены, а потому гармоничность города - не конечное состояние, а непрерывный креативный процесс, направленный на постоянное совершенствование.

\section{Выводы}

Глобализация, развитие новых технологий и ряд связанных с ними факторов неизбежно ведут города к кардинальной трансформации. В этом ключе проблемы города рассматриваются как источники новых возможностей, а его развитие базируется на целенаправленных стратегиях, предполагающих инновационные методы управления. Для того чтобы этот механизм заработал, необходимо формирование специальных знаний и навыков, позволяющих разрабатывать новые гибкие стратегии развития города на междисциплинарной основе, выявлять скрытые источники потенциального роста, пользоваться прогрессивными инструментами политики одновременно на концептуальном, дисциплинарном и внедренческом уровнях. При этом потребуются подготовка городских управленцев по специально разработанным программам, партнерство с исследовательскими университетами, создание собственных департаментов исследования городского развития и т. п. От наличия либо отсутствия подобных факторов зависят сценарии будущего городов - постепенный упадок либо полные энергии города с новым качеством жизни.

Берч Д., Бин Д., Блайденберг Э., Боргсдорф Д., Марсталл Д., Савельев О. (2010) Опыт города Шарлотт. «Дорожная карта» преобразования и повышения эффективности системы городского управления. М.: Олимп-Бизнес.

Бокарева Н. (2009) «Зеленая революция» в Британии стартовала экогородами. http://www.bfm.ru/articles/2009/07/22/v-velikobritaniiodobreny-chetyre-plana-sozdanija-ekogorodov.html

Бэйли Р. (2011) Принципы развития устойчивого городского сообщества. Опыт Ванкувера. Публичная лекция на ПОЛИТ.py. http://polit. ru/article/2011/10/25/bayley_anons/

Вендина О. (2010) Невидимые сдвиги в развитии городов // Демоскоп Weekly. № 407-408 (25 января - 7 февраля). http://demoscope.ru/ weekly/2010/0407/analit01.php

Дорошенко М.Е. (2011) Инновационный потенциал сектора интеллектуальных услуг в России // Форсайт. Т. 5. № 4. С. 50-65.

Лэндри Ч. (2011) Публичная лекция 22 марта 2011 года. http://www.creativeindustries.ru/rus/241

Слука Н. (2008) Глобальные города // Эксперт. № 15. С. 23-26.

Флорида Р. (2002) Креативный класс: люди, которые определяют будущее. М.: Классика-XXI.

Харви Д. (2009) Утопии и проблема их воплощения // Проект International. № 2. С. 158-165.

Щукин А. (2011) Время заняться городами // Эксперт. № 40 (773), 10 октября. С. 24-26.

Anderson A.E. (1987) Culture, Creativity and Economic Development in a Regional Context. Project № 10, Seminar № 5. Strasbourg: Council for Cultural Co-operation

Bianchini F., Ghilardi S. (1997) Culture and Neighborhoods: A Comparative Report. Strasbourg: Council of Europe.

Cisco (2007) Строительная отрасль на пороге революции. http://www.cisco.com/web/RU/news/releases/txt/1384.html

Climate Group (2008) SMART 2020: Enabling the Low Carbon Economy in the Information Age. A report by The Climate Group on behalf of the Global eSustainability Initiative (GeSI). Creative Commons. http://www.smart2020.org/_assets/files/02_Smart2020Report.pdf

Douglass M. (2002) From global intercity competition to cooperation for livable cities and economic resilience in Pacific Asia //

Environment\&Urbanization. Vol. 14. № 1 (April). P. 53-68.

Hall P. (1995) The roots of urban innovation: culture, technology and the urban order // Urban Futures. № 19. P. 41-52.

Hall P. (1998) Cities in Civilisation. London: Weidenfeld.

IBM (2009a) A vision of smarter cities: How cities can lead the way into a prosperous and sustainable future. IBM Institute for Business Value.

IBM (2009b) IBM и город Чесапик строят разумный город. http://www.ibm.com/news/ru/ru/2009/12/07/q868442i18826a10.html

Jacobs J. (1993) The Death and Life of Great American Cities. New York: Random House.

Jacobs J. (1998) Staging difference: aestheticization and the politics of difference in contemporary cities // Fincher R., Jacobs J.M. (eds.) Cities of Difference. New York: Guilford. P. 252-278.

Landry C. (2008) The Creative City: A Toolkit for Urban Innovators (2nd ed.). London: Earthscan.

Parnreiter C. (2009) Megacities in the Geography of Global Economic Governance // Die Erde. Vol. 140. № 4. P. 371-390.

Porter M.E. (1980) Competitive Strategy: Techniques for Analyzing Industries and Competitors. New York. Free Press.

Sassen S. (1994) Cities in a world economy. Thousand Oaks: Pine Forge Press.

Scott A.J. (2006) Creative cities: Conceptual issues and policy questions // Journal of Urban Affairs. Vol 28. № 1. P. 1-17.

Siemens (2006) Перспективы мегаполисов. Available at: https://www.cee.siemens.com/web/ua/ru/Documents/megapolis.pdf. Accessed: 24 October 2011. Accessed: 30 November 2011.

Simmie J., Strambach S. (2006) The Contribution of KIBS to Innovation in Cities: An Evolutionary and Institutional Perspective // Journal of Knowledge Management. Vol. 10. № 5. P. 26-40.

Steinert K., Marom R., Richard P., Weiga G., Witters L. (2011) Making Cities Smart and Sustainable // The Global Innovation Index 2011 (ed. S. Dutta). Fontainbleau: INSEAD. P. 87-95.

The Economist (2011) World in Figures 2011. Available at: http://www.economist.com/theworldin/2011. Accessed 30 November 2011.

UN (2009) World Urbanization Prospects: The 2009 Revision. New York.

Urban Indicators Guidelines (2004) Monitoring Habitat Agenda and Millennium Development Goals. United Nations Human Settlements Programme.

Vancouver City Council (2009) Vancouver 2020: A Bright Green Future. An Action Plan for Becoming the World’s Greenest City by 2020. Vancouver. 


\title{
Urban Futures: Cities as Agents of Globalization and Innovation
}

\author{
Marina Boykova \\ Executive Editor, Foresight journal, Institute for Statistical Studies and Economics of Knowledge, National Research University - \\ Higher School of Economics, 20 Myasnitskaya str., Moscow, 101000, Russian Federation. E-mail: foresight-journal@hse.ru
}

\section{Irina Ilyina}

Director, Centre for Regional Studies, Institute for Regional Studies and Urban Planning, National Research University Higher School of Economics, 20 Myasnitskaya str., Moscow, 101000, Russian Federation. E-mail: iilina@hse.ru

\section{Mikhail Salazkin}

Junior Research Fellow, Institute for Statistical Studies and Economics of Knowledge, National Research University Higher School of Economics, 20 Myasnitskaya str., Moscow, 101000, Russian Federation. E-mail: msalazkin@hse.ru

\begin{abstract}
$\mathrm{T}$ he complexity of globalization is strongly indicated by the rapid growth of urban areas and expanding megacities, where the majority of the world' population is concentrated and new socio-economic phenomena are shaped. This makes issues of urban perspectives utterly relevant. In recent years, this area is covered by numerous studies, most of the world's renowned urbanists and experts in the areas, one way or another connected with the development of the urban environment, share the viewpoint on radically changing global context that leads to a paradigm shift with regard to urban development.

Since the evolution adhered to the conventional imperative "growth a tout prix" can no longer ensure the harmonious development and high-quality habitat, so a new philosophy of urban development emerges. An urgent task is to gain a new image of a healthy and creative city.

The paper considers the essence of the processes that put in the pledge of the changing paradigm, explores new approaches, concepts and policy instruments that are essential for the transition to a higher level of urban environment quality. It is generally acknowledged that lateral thinking presuming an explicit division of an urban territory into functional areas is no longer up to date and it is necessary to take up creative, synthesis and multidisciplinary approaches. In the framework of the latter a city is regarded as a holistic organism, whereas challenges are interpreted as a source of new opportunities.

In order to meet the consistency criteria, a city should function as a single system that is being one large project, aptly integrated by participative creativity and innovative spirit. Achieving such an objective cannot have a general solution; it all depends on the specifics of a particular city.

The authors give examples of successfully implemented urban strategies that can be a role model for cities that have embarked on choosing a new direction of development.

The realization of such innovative strategies requires a critical mass of like-minded innovators who can lead the process of urban transformation. This becomes possible by the formation of human capital, capable of developing new flexible strategies on an interdisciplinary basis, identifying implicit sources of potential growth and using the advanced policy instruments simultaneously at the conceptual, disciplinary and promotional levels. This requires the restructuring of the governance system and training city managers by earmarked programmes, partnering with research universities, the creation of $R \& D$ departments within municipal governing bodies, and an active involvement of citizens in decision-making process regarding to the city development, etc. The availability or lack of these factors predetermines scenarios of urban development - whether would it be a gradual decline or the formation of a "vibrant" environment with a higher quality of life.
\end{abstract}

\section{Keywords}

strategy of urban development, urban population, urbanization, global city, creative city, eco-city, smart city

\section{References}

Anderson A.E. (1987) Culture, Creativity and Economic Development in a Regional Context. Project no 10, Seminar no 5, Strasbourg: Council for Cultural Co-operation.

Bayley R. (2011) Printsipy razvitiya ustoichivogo gorodskogo soobshchestva. Opyt Vankuvera. Publichnaya lektsiya na POLIT.ru. [Principles of Developing Sustainable Urban Communities. A Case of Vancouver. Public Lecture at POLIT.ru]. Available at: http://polit.ru/ article/2011/10/25/bayley_anons/ (accessed 5 December 2011).

Berch D., Bin D., Blaidenberg E., Borgsdorf D., Marstall D., Savel'ev O. (2010) Opyt goroda Sharlott. "Dorozhnaya karta" preobrazovaniya $i$ povysheniya effektivnosti sistemy gorodskogo upravleniya [The Case of Sharlott. Roadmapping for Restructuring and Enhancing Efficiency of the Urban Planning System], Moscow: Olimp-Biznes. 
Bianchini F., Ghilardi S. (1997) Culture and Neighborhoods: A Comparative Report, Strasbourg: Council of Europe.

Bokareva N. (2009) «Zelenaya revolyutsiya» $v$ Britanii startovala ekogorodami [The Green Revolution in Britain has started with Eco-Cities]. Available at: http://www.bfm.ru/articles/2009/07/22/v-velikobritanii-odobreny-chetyre-plana-sozdanija-ekogorodov.html (accessed 5 December 2011).

Cisco (2007) Stroitel'naya otrasl' na poroge revolyutsii [The Construction Industry on the Verge of Revolution]. Available at: http://www.cisco.com/ web/RU/news/releases/txt/1384.html (accessed 5 December 2011).

Climate Group (2008) SMART 2020: Enabling the Low Carbon Economy in the Information Age, Creative Commons.

Doroshenko M.E. (2011) Innovatsionnyi potentsial sektora intellektual'nykh uslug v Rossii [Innovative Potential of the Knowledge-Intensive

Services Sector in Russia]. Foresight-Russia, vol. 5, no 4, pp. 50-65.

Douglass M. (2002) From global intercity competition to cooperation for livable cities and economic resilience in Pacific Asia.

EnvironmenteUrbanization, vol. 14, no 1, pp. 53-68.

Florida R. (2002) Kreativnyi klass: lyudi, kotorye opredelyayut budushchee [Creative Class: People Who Shape the Future], Moscow: Klassika-XXI.

Hall P. (1995) The roots of urban innovation: culture, technology and the urban order. Urban Futures, no 19, pp. 41-52.

Hall P. (1998) Cities in Civilisation, London: Weidenfeld.

Harvey D. (2009) Utopii i problema ikh voploshcheniya [Utopias and Difficulties of Their Realization]. Project International, no 2, pp.158-165. IBM (2009a) A vision of smarter cities: How cities can lead the way into a prosperous and sustainable future. IBM Institute for Business Value.

IBM (2009b) IBM i gorod Chesapik stroyat razumnyi gorod [IBM and Chesapeake build a Smart City]. Available at: http://www.ibm.com/news/ $\mathrm{ru} / \mathrm{ru} / 2009 / 12 / 07 / \mathrm{q} 868442 \mathrm{i} 18826 \mathrm{1} 10 . \mathrm{html}$ (accessed 5 December 2011).

Jacobs J. (1993) The Death and Life of Great American Cities, New York: Random House.

Jacobs J. (1998) Staging difference: aestheticization and the politics of difference in contemporary cities. Cities of Difference (eds. R. Fincher,

J.M.Jacobs), New York: Guilford, pp. 252-278.

Landry C. (2008) The Creative City: A Toolkit for Urban Innovators (2nd ed.), London: Earthscan.

Landry C. (2011) Publichnaya lektsiya [Public Lecture, March 22, 2011]. Available at: http://www.creativeindustries.ru/rus/241 (accessed 5 December 2011).

Parnreiter C. (2009) Megacities in the Geography of Global Economic Governance. Die Erde, vol. 140, no 4, pp. 371-390.

Porter M.E. (1980) Competitive Strategy: Techniques for Analyzing Industries and Competitors, New York: Free Press.

Sassen S. (1994) Cities in a world economy, Thousand Oaks: Pine Forge Press.

Scott A.J. (2006) Creative cities: Conceptual issues and policy questions. Journal of Urban Affairs, vol. 28, no 1, pp. 1-17.

Shchukin A. (2011) Vremya zanyat'sya gorodami [Time to Deal with Cities]. Ekspert, no 40 (773), pp. 24-26.

Simmie J., Strambach S. (2006) The Contribution of KIBS to Innovation in Cities: An Evolutionary and Institutional Perspective. Journal of Knowledge Management, vol. 10, no 5, pp. 26-40.

Sluka N. (2008) Global’nye goroda [Global cities]. Ekspert, no 15, pp. 23-26.

Steinert K., Marom R., Richard P., Weiga G., Witters L. (2011) Making Cities Smart and Sustainable. The Global Innovation Index 2011 (ed.

S. Dutta), Fontainbleau: INSEAD, pp. 87-95.

UN (2009) World Urbanization Prospects: The 2009 Revision, New York.

United Nations Human Settlements Programme (2004) Urban Indicators Guidelines. Monitoring Habitat Agenda and Millennium Development Goals.

Vancouver City Council (2009) Vancouver 2020: A Bright Green Future. An Action Plan for Becoming the World's Greenest City by 2020, Vancouver.

Vendina O. (2010) Nevidimye sdvigi v razvitii gorodov [Invisible Shifts in Urban Development]. Demoscope Weekly, no 407-408. Available at: http://demoscope.ru/weekly/2010/0407/analit01.php (accessed 5 December 2011).

\section{ИНДИКАТОРЫ}

Внутренние затраты на исследования и разработки по приоритетным направлениям развития науки, технологий и техники

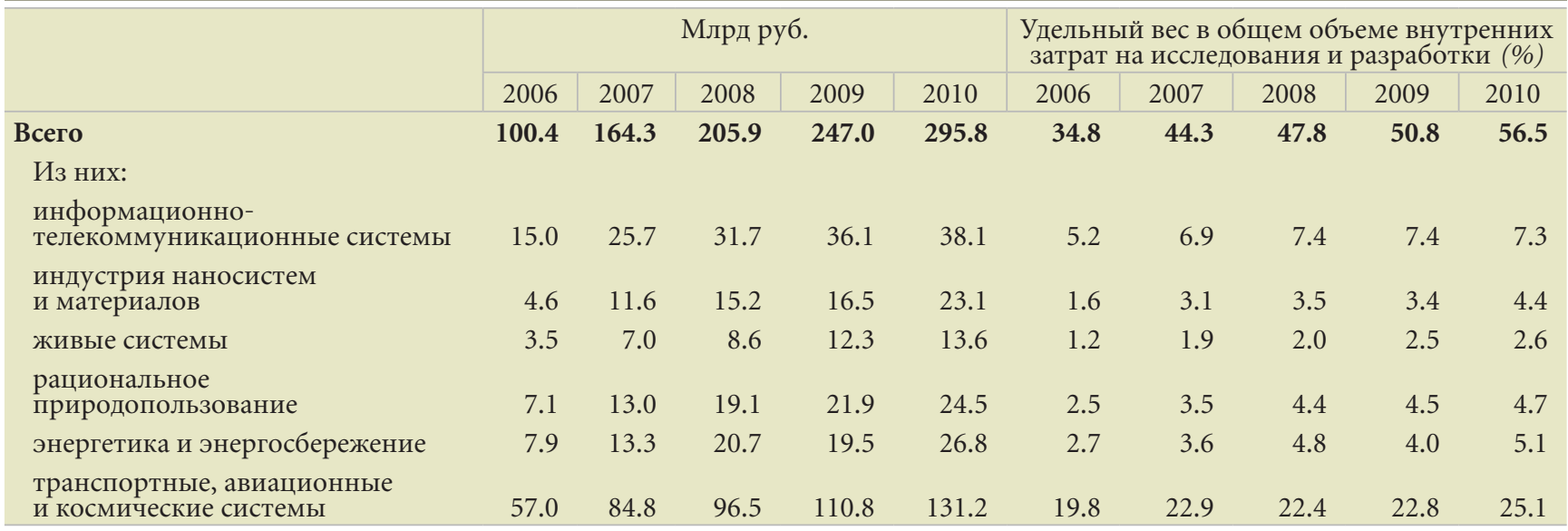




\section{Инновации - залог стабильности в период кризиса}

\begin{abstract}
Питер Шварц - автор концепции сценарного планирования, председатель Совета директоров компаний Global Business Network и Monitor Group, член Международного наблюдательного совета Форсайт-центра ИСИЭЗ НИУ ВШЭ и совета директоров ряда организаций, консультант, автор многочисленных книг и лекционных курсов - знаковая фигура в сфере стратегического прогнозирования.
\end{abstract}

Свое видение будущего он изложил в краткой беседе с нашим корреспондентом.

С момента выхода Вашей книги «Искусство долгосрочного предвидения: планирование будущего в условиях неопределенности» ${ }^{1}$ прошло двадцать лет. Можно ли сегодня говорить о возросшем интересе к этой теме?

С увеличением неопределенности и рисков актуальность стратегического мышления и долгосрочного планирования повышается. Практически каждая сфера нашей деятельности характеризуется колоссальным ростом «серых зон» в перспективе. Появление таких экономических гигантов, как Китай и Индия, усиление глобальной интеграции и трансформация финансовой системы привели к увеличению объема, усложнению структуры мировой экономики и повышению ее неопределенно сти. Инновации способны не только преобразить традиционные сектора, но и поднять «волну», сметающую социально-экономические уклады. Проблема глобаль ного изменения климата уже не оставляет энергоемким секторам иного сценария, кроме кардинальной перестройки. В подобных условиях сценарное планирование - один из наиболее эффективных инструментов управления неопределенностью и минимизации последствий неизбежных «шоковых» событий.

Какие стратегические ориентиры в обозримой перспективе представляются наиболее актуальными?

Я бы выделил три тесно взаимосвязанные базовые задачи - обеспечение мирных условий существования, рост благосостояния, повышение социальной и экологической ответственности. Продолжающаяся волна финансовых кризисов, дефициты госбюджетов США и европейских стран, поддержка современных тем пов развития экономик БРИКС формируют комплекс серьезных вызовов для национальных правительств. Вектор глобального развития напрямую зависит от их успешного решения. Замедление экономического роста, усиление неравенства в доходах, протекционизм, а также увеличение числа влиятельных игроков повышают вероятность конфликтов. Растущие темпы потребления ресурсов создают колоссальную нагрузку на экосистемы, угрожая катастрофической дестабилизацией климата. Для предотвращения или минимизации указанных факторов предстоит разрешить ряд сложных дилемм и сбалансировать меры внешней и внутренней политики.

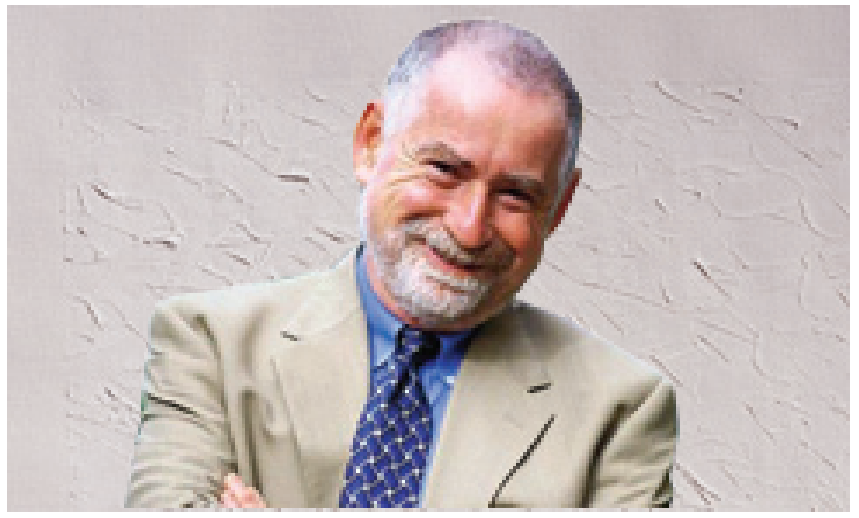

Каким образом Россия может извлечь преимущества из высоких цен на сырье?

Циклы колебания цен на сырье переменчивы. Оптимальным сценарием может стать направление сверхприбыли от экспорта сырья в резервные фонды, инвестиции в исследования и разработки, модернизацию инфраструктуры, повышение качества образования. Подобная капитализация позволит эффективно перераспределить доходы из добывающих секторов и обеспечить экономическую стабильность в период падения цен.

В каких областях науки и технологий сегодня формируются скрытые источники роста?

Пристального внимания заслуживает синтетическая биология, позволяющая модифицировать микроорганизмы. Научившись производить подобным образом углеводородные топлива, разнообразные химические вещества, материалы, выращивать человеческие органы, можно выйти на качественно новый уровень развития. Достижения в области физики обеспечат развитие новых экологически чистых источников энергии, таких как лазерный синтез и солнечная энергетика. Прорыв в квантовой науке приведет к колоссальному росту вычислительных мощностей и повлияет на другие научные дисциплины. Умение оперировать материей на наноуровне позволит создавать новые конструкционные материалы и классы машин.

Вы ознакомились с дорожными картами, разработанными специалистами НИУ ВШЭ. Как Вы их оцениваете?

Моей компетенции в соответствующих сферах недостаточно для объективной оценки собственно контента карт. Тем не менее, их проработанность выглядит впечатляющей, что, полагаю, потребовало немалых усилий. Дорожные карты станут ценным инструментом при планировании дальнейших отраслевых исследований и помогут руководителям в выборе приоритетов. Глубина исследований, проведенных при составлении дорожных карт, может гарантировать надежность решений, принимаемых на их основе. 


\title{
Инновационный потенциал сектора интеллектуальных услуг в России'
}

\author{
М.Е. Дорошенко*
}

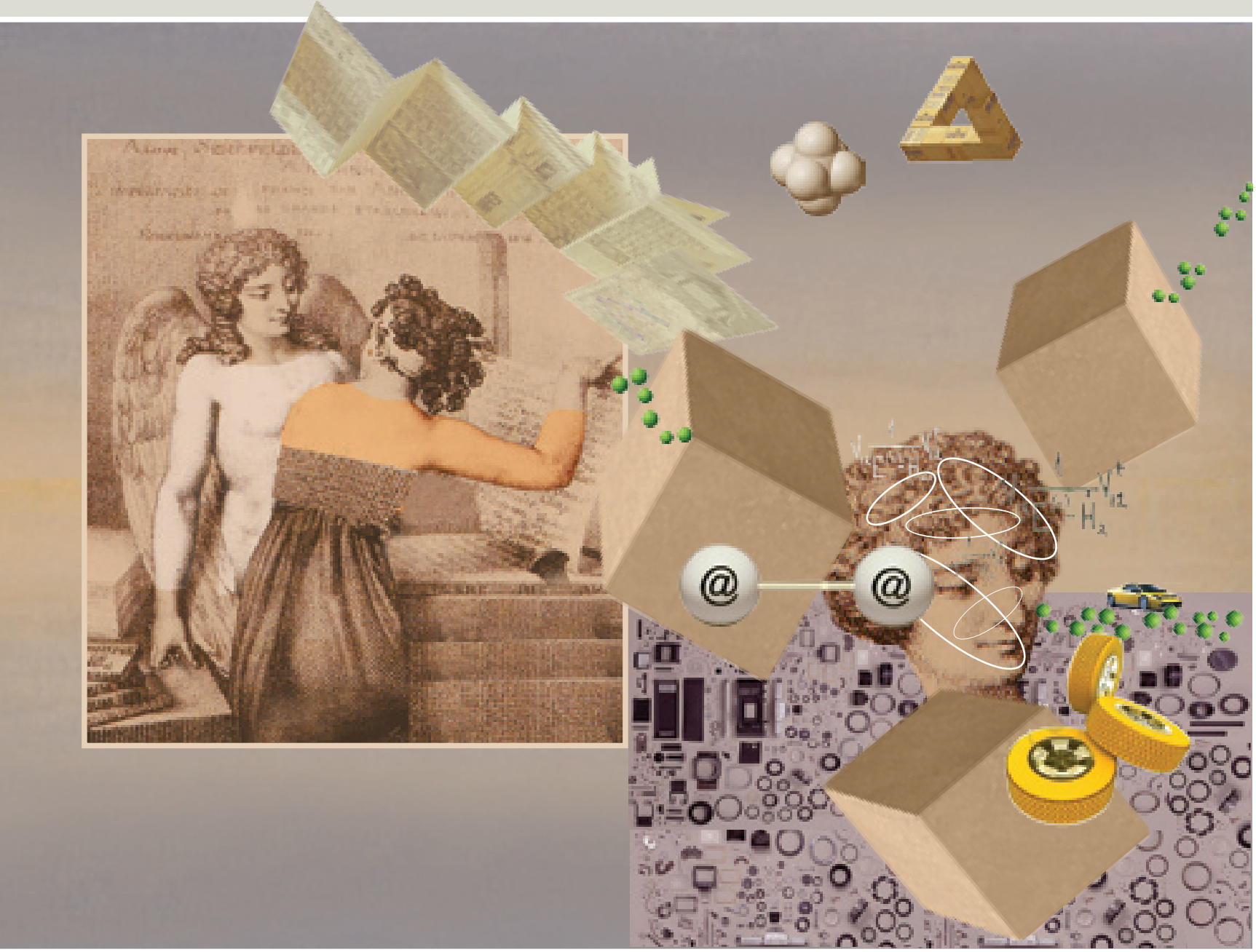

В сфере интеллектуальных услуг прослеживается тенденция к индивидуализации продукции, которую усиливает самоподдерживающийся инновационный механизм. Рыночный спрос стимулирует сервисных провайдеров к разработке инноваций. В свою очередь, пользование персонализированными услугами повышает новаторский потенциал потребителя, его потребность в подобных услугах и, как следствие, инновационную ориентированность производителя.

На основе результатов мониторинга сектора интеллектуальных услуг, проводимого ИСИЭЗ НИУ ВШЭ с 2006 г., в статье раскрывается специфика производства и потребления кастомизированных услуг, оценивается их вклад в распространение экономики знаний. 
И нтеллектуальные услуги (knowledge-intensive services) становятся важным звеном формирующейся «экономики знаний», привлекая к себе растущее внимание исследователей во всем мире. Ключевым элементом здесь выступает сектор интеллектуальных деловых услуг (knowledgeintensive business services, KIBS), который уже сейчас вносит ощутимый вклад в ВВП и занятость в развитых странах [OECD, 2007, p. 90].

Интерес исследователей, однако, вызван не только и не столько количественными, сколько качественными характеристиками этой категории услуг. «Знаниеемкость» интеллектуальных услуг превращает их в «один из главных атрибутов экономики, основанной на знаниях» [European Commission, 2005 , p. 1] и в «центры добавленной стоимости» [Gibbons et al., 1994]. Высокую инновационную активность компаний, производящих интеллектуальные услуги, отмечают многие авторы, характеризуя их как активных потребителей, носителей и производителей инноваций [Miles et al., 1995a,b].

Следует, однако, заметить, что подавляющее большинство исследований инновационной активности сектора интеллектуальных услуг охватывают государства с развитыми экономиками. Например, в обзоре [Muller, Doloreux, 2007] указано, что из 82 проанализированных публикаций только две написаны авторами из Восточной Европы (примером может служить [Balaz, 1994]), при этом страны, не входящие в ЕС, не представлены вовсе. Между тем развивающиеся рынки имеют свои особенности и часто демонстрируют процессы и явления, которые на рынках развитых стран отсутствуют либо проявляются в слабой форме. Опираясь на данные, полученные в ходе мониторинга сектора интеллектуальных услуг, осуществляемого ИСИЭЗ НИУ ВШЭ с 2006 г., мы покажем, что это утверждение в полной мере справедливо для характеристик инновационного потенциала сектора интеллектуальных услуг.

\section{Инновации в секторе} интеллектуальных услуг

\section{Сервисные инновации индустриального и постиндустриального типа}

В работах многих исследователей [Evangelista, Savona, 1998; Tether et al., 2001; и др.) выделяются два основных направления сервисных инноваций: одно ориентировано на стандартизацию оказываемых услуг, второе - на их кастомизацию.

Первое направление предполагает деятельность, нацеленную на доведение дизайна услуги до тиражируемого формата. Это не настолько простая задача, как может показаться на первый взгляд, с учетом того, что интеллектуальная услуга нематериальна и, строго говоря, невоспроизводима, так как оказывается каждому заказчику индивидуально. Поэтому процесс создания тиражируемой услуги представляет собой высоко креативную, творческую работу: вначале необходимо вычленить типовую составля- ющую (что требует хорошего знания потребителя и умения составить его «репрезентативный портрет»), а затем разработать методику и инструментарий, позволяющие воспроизводить услугу с минимальными издержками. Примерами такой деятельности служат разработка формата сбора данных и алгоритма их последующей обработки при проведении обязательного аудита, подготовка типовых юридических советов и рекомендаций, создание дизайнерских проектов для квартир стандартной планировки с учетом среднестатистических вкусов и потребностей жильцов и т. п.

Как видим, создание типового решения, безусловно, является образцом инновационной деятельности, требующей высокой квалификации и опыта. В случае удачного результата стандартная услуга может широко реплицироваться. Важным условием успешности подобного тиражирования является возможность осуществлять его с небольшими предельными издержками. Речь идет в первую очередь о расходах на оплату труда, поскольку деятельность по оказанию интеллектуальных услуг отличается низкой капиталоемкостью. Следовательно, для успешного продвижения стандартных услуг необходимо, чтобы их мог оказывать персонал с относительно невысокими квалификацией и опытом. При этом главным фактором эффективности производства становится обычная экономия от масштаба: по мере роста объема услуг исполнители все больше «набивают руку», время оказания услуг сокращается, так что средние переменные издержки уменьшаются, а вместе с ними может снижаться и цена. В итоге бизнесмодель, лежащая в основе данного процесса, мало отличается от той, что используется в промышленном поточном производстве: выпускать много и продавать дешево за счет эффекта масштаба. Не случайно описываемое направление (рутинизацию производства услуг) часто называют «сервисной индустриализацией» [Levitt, 1972].

Подобному типу производства отвечают классические рынки сбыта, где господствует массовый (недиверсифицированный) спрос. Основным конкурентным преимуществом на таком рынке становится низкая цена.

Стандартная продукция, включая как товары, так и услуги, остается востребованной во всем мире. Зародившееся еще в XIX столетии массовое производство не сдает позиции, приняв во многих отраслях глобальный характер. Для современного потребителя ценно, что DVD-диск, вне зависимости от страны, в которой он был приобретен, подойдет к любому считывающему устройству, а автомобиль повсеместно может быть заправлен бензином соответствующей марки. То же касается и сферы интеллектуальных услуг. Процедура получения наличных денег в банкомате настолько унифицирована, что этой услугой можно пользоваться, даже не зная ни одного из языков, запрограммированных в устройстве. На сайте любой солидной юридической компании найдется раздел «Часто задаваемые вопросы», 
который позволяет получить стандартные правовые консультации бесплатно. Тиражирование «коробочного» программного обеспечения является важной статьей дохода компаний, оказывающих услуги в сфере информационных и коммуникационных технологий (ИКТ). Таким образом, инновации стандартизованного типа продолжают играть значимую роль в развитии современного производства. Как уже отмечалось, разработка подобных инноваций является знаниеемкой и креативной деятельностью, причем это касается не только создания собственно инновации, но и ее трансформации с целью широкого тиражирования. Зато впоследствии производство услуги становится рутинной операцией, доступной даже для средне- и низкоквалифицированных работников, что и дает возможность на этапе репликации пользоваться выгодами экономии от масштаба.

Однако наряду с развитием массового производства набирает силу, особенно в последние десятилетия, противоположная тенденция - к индивидуализации (кастомизации) производства, т. е. к выпуску изделий в мелкосерийном и даже единичном масштабе. Рынки подобной продукции не носят массового характера, они сегментированы до малочисленных групп потребителей или даже отдельных субъектов. Индивидуализированная продукция адаптируется под конкретные потребности пользователя, так что каждая единица продукции, по сути, является продуктовой инновацией.

Разумеется, кастомизированное производство не может быть дешевым, поэтому конкуренция за счет низких цен, устанавливаемых благодаря экономии от масштаба, становится невозможной. Индивидуализированная продукция находит свои ниши там, где по какой-либо причине, будь то дань моде, стремление к самовыражению или объективная непохожесть чьей-либо потребности на нужды других субъектов, спрос на реплику (вторую копию) отсутствует. Поскольку пользователи такой продукции ценят именно ее уникальность, то именно это качество (нереплицируемость) становится основным конкурентным преимуществом в борьбе за потребителя.

Тенденция к кастомизации в промышленности прослеживается пока довольно фрагментарно, несмотря на то, что существуют целые отрасли, специфика которых требует мелкосерийного и даже штучного выпуска (производство космической техники, гидротурбин, атомная промышленность и др.). В отраслях категории В2С индивидуализация представлена слабее, в том числе и по причине того, что технологии относительно дешевого индивидуального производства не получили существенного развития. Тем не менее, число подобных технологий стремительно увеличивается (примером служит современный «3D-принтер», позволяющий воплощать в пластике трехмерные компьютерные проекты). Ожидается, что более широкие перспективы в данном направлении появятся с развитием нанотехнологий, позволяющих осуществлять самосборку изделия на молекулярном уровне, обеспечивая тем самым автоматическое изготовление продукции с индивидуальными свойствами на уровне строения вещества.

Тенденция к индивидуализации постепенно набирает обороты, особенно в зрелых рыночных системах. «По некоторым оценкам, в настоящее время доля массового производства в развитых странах составляет уже не более трети общего объема выпущенной продукции, остальное приходится на мелкосерийные изделия (от 10 до 2000 штук), ориентированные на вкусы того или иного контингента покупателей, при этом цикл изготовления значительно сокращается» [Хорос, 2000, c. 170]. Конечно, во многом это связано с тем, что центры поточного производства переносятся на периферию рыночной экономики, в «мастерские мира» (главной из которых сегодня является Китай), но растет и востребованность инноваций кастомизированного типа. Ожидается, что в будущем, по мере распространения постиндустриального типа экономического роста, основанного на инновационном диверсифицированном производстве, эта тенденция будет усиливаться. «В постинформационной мировой экономике вопросы тиражирования товаров в принципе будут решаться без особых затрат дефицитных ресурсов, на базе компьютеризированных и «рутинизированных» производств. Основные экономические проблемы будут связаны с разработкой и созданием новых нестандартных изделий, удовлетворяющих индивидуальные потребности конкретного человека или уникального производства. Проблема создания новых товаров займет ведущее место в ряду экономических проблем, a economics of scale уступит место есоnomics of scope. Из преимущественно репликационной экономика превратится в преимущественно инновационную, следовательно - индивидуализированную» [Макаров, Клейнер, 2007, с. 37].

Наиболее отчетливо тенденция к индивидуализации производства в настоящее время прослеживается все-таки в сфере услуг, особенно интеллектуальных, практически не нуждающихся для развития соответствующих инноваций в «техническом обеспечении» в форме материального капитала. Собственно, услуги данного типа и названы «интеллектуальными» благодаря высокой доле кастомизированного выпуска, представляющего собой череду продуктовых инноваций, генерируемых высококвалифицированным персоналом. Поэтому каждая единица таких услуг знаниеемка, в отличие от стандартной продукции, где креативная, инновационная деятельность сосредоточена только в начале (на этапе «изобретения» и доведения до реплицируемого формата), а затем производство может осуществляться без активного применения знаний.

Данные, полученные нами в ходе опросов производителей интеллектуальных услуг в России, подтверждают, что обе тенденции (к индустриализации и к индивидуализации) в секторе интеллектуальных услуг примерно равносильны (табл. 1). Из таблицы видно, что примерно половина услуг не являются типовыми, поэтому их производство знаниеемко и требует креативных усилий по адаптации к потребностям конкретного заказчика. 
Табл. 1. Соотношение стандартной и кастомизированной продукции в российском секторе интеллектуальных услуг (\%) *

\begin{tabular}{|l|c|c|}
\hline & $\begin{array}{c}\text { Стандарти- } \\
\text { зированные } \\
\text { услуги }\end{array}$ & $\begin{array}{c}\text { Кастомизиро- } \\
\text { ванные } \\
\text { услуги }\end{array}$ \\
\hline Услуги рекламы & 45.7 & 54.3 \\
\hline $\begin{array}{l}\text { Маркетинговые } \\
\text { услуги }\end{array}$ & 36.5 & 63.5 \\
\hline Услуги в области ИКТ & 59.7 & 40.3 \\
\hline $\begin{array}{l}\text { Аудиторские } \\
\text { услуги }\end{array}$ & 60.4 & 39.6 \\
\hline $\begin{array}{l}\text { Услуги по подбору } \\
\text { Персонала }\end{array}$ & 40.3 & 59.7 \\
\hline $\begin{array}{l}\text { Инжиниринговые } \\
\text { услуги }\end{array}$ & 47.1 & 52.9 \\
\hline $\begin{array}{l}\text { Услуги финансового } \\
\text { посредничества }\end{array}$ & 50.1 & 49.9 \\
\hline Юридические услуги & 23.4 & 76.6 \\
\hline $\begin{array}{l}\text { Услуги в области } \\
\text { недвижимости }\end{array}$ & 48.3 & 51.7 \\
\hline $\begin{array}{l}\text { Дизайнерские } \\
\text { услуги }\end{array}$ & 59.2 & 40.8 \\
\hline $\begin{array}{l}\text { Средневзвешенная } \\
\text { по сектору }\end{array}$ & $\mathbf{4 7 . 0}$ & $\mathbf{5 3 . 0}$ \\
\hline
\end{tabular}

* Источником данных в этой и последующих таблицах являются расчеты ИСИЭЗ НИУ ВШЭ.

\section{Инновационная активность компаний сектора интеллектуальных услуг}

Учитывая процент кастомизированной продукции в составе сектора, неудивительно, что производство интеллектуальных услуг отличается высоким уровнем инновационной активности. Доля инновационной продукции намного превышает средний показатель по промышленности и вполне сопоставима с наиболее высокотехнологичными ее отраслями (табл. 2, 3).

\section{Табл. 2. Доля инновационной продукции в общем объеме выпуска сектора интеллекуальных услуг (\%)}

\begin{tabular}{|c|c|}
\hline Годы & Средневзвешенное значение \\
\hline $2007-2008$ & 9.2 \\
\hline 2009 & 10.6 \\
\hline 2010 & 19.9 \\
\hline
\end{tabular}

Примечательно, что интенсивность инноваций в секторе интеллектуальных услуг резко возросла во время кризиса: доля инновационных услуг за год увеличилась вдвое. Производители объясняют это существенным сокращением спроса на рынках (табл. 4), потребовавшим значительных усилий по выживанию.

Столь сильная реакция на кризис отчасти обусловлена тем, что интеллектуальные услуги в нашей стране все еще воспринимаются как «предметы роскоши», без которых в принципе можно обойтись. Исследования показывают, что на полный аутсорсинг российские компании переходят крайне редко, несмотря на то, что деятельность, составляющая специализацию провайдеров интеллектуальных услуг, является для них непрофильной. Даже до кризиса, в благополучном 2007 г. средний уровень аутсорсинга составлял всего 13\% (табл. 5).

Соответственно, ради экономии на издержках, принявшей во время кризиса тотальный характер, многие потребители либо полностью отказались от приобретения услуг, либо переключились с аутсорсинга на собственное производство.

Еще более существенную роль, по мнению производителей услуг, сыграло отсутствие какой-либо государственной поддержки (за исключением банковской сферы, образующей часть финансового

\section{Табл. з. Удельный вес инновационных товаров, работ, услуг в общем объеме отгруженных} товаров, выполненных работ, услуг организаций Российской Федерации (\%)

\begin{tabular}{|c|c|c|c|}
\hline & 2007 & 2008 & 2009 \\
\hline Всего & 4.6 & 5.0 & 4.6 \\
\hline С- Добыча полезных ископаемых & 3.0 & 3.0 & 2.7 \\
\hline D - Обрабатывающие производства & 7.1 & 6.6 & 6.1 \\
\hline DA - Производство пищевых продуктов, включая напитки, и табака & 5.3 & 4.6 & 4.8 \\
\hline DB — Текстильное и швейное производство & 2.5 & 1.6 & 4.7 \\
\hline DC - Производство кожи, изделий из кожи и производство обуви & 2.9 & 1.9 & 6.1 \\
\hline DD - Обработка древесины и производство изделий из дерева & 2.2 & 6.6 & 2.1 \\
\hline DE - Целлюлозно-бумажное производство; издательская и полиграфическая деятельность & 2.9 & 2.0 & 2.7 \\
\hline DF - Производство кокса, нефтепродуктов и ядерных материалов & 3.4 & 4.4 & 1.6 \\
\hline DG - Химическое производство & 12.0 & 11.9 & 11.4 \\
\hline DH - Производство резиновых и пластмассовых изделий & 9.1 & 5.5 & 6.8 \\
\hline DI - Производство прочих неметаллических минеральных продуктов & 3.4 & 2.4 & 3.0 \\
\hline DJ - Металлургическое производство и производство готовых металлических изделий & 5.0 & 4.6 & 5.5 \\
\hline DK - Производство машин и оборудования & 6.1 & 7.5 & 8.3 \\
\hline DL - Производство электрооборудования, электронного и оптического оборудования & 10.2 & 8.8 & 9.9 \\
\hline DM - Производство транспортных средств и оборудования & 18.4 & 17.9 & 16.2 \\
\hline DN - Прочие производства & 11.3 & 5.1 & 5.8 \\
\hline E - Производство и распределение электроэнергии, газа и воды & 0.4 & 0.6 & 1.0 \\
\hline
\end{tabular}




\begin{tabular}{|l|c|}
\hline \multicolumn{2}{|c|}{ табл. 4. Изменение спроса на услуги } \\
компаний сектора интеллектуальных \\
Услуг: 2009 (\%) \\
\hline \multicolumn{2}{|c|}{} \\
\hline & $\begin{array}{c}\text { Изменение } \\
\text { объма рынка } \\
\text { в 2009 г. по } \\
\text { сравнению } \\
\text { с 2008 г. }\end{array}$ \\
\hline Услуги рекламы & -17.2 \\
\hline Маркетинговые услуги & -15.2 \\
\hline Аудиторские услуги & -12.8 \\
\hline Услуги в области ИКТ & -9.3 \\
\hline Услуги по подбору персонала & -14.3 \\
\hline Инжиниринговые услуги & -19.8 \\
\hline Услуги финансового посредничества & -5.2 \\
\hline Юридические услуги & 0.1 \\
\hline Услуги в области недвижимости & -17.8 \\
\hline Дизайнерские услуги & -14.3 \\
\hline Средневзвешенная по сектору & -12.5 \\
\hline
\end{tabular}

посредничества). В то время как для многих отраслей экономики разрабатывались пакеты антикризисных мер, сфера интеллектуальных услуг была предоставлена самой себе. Чтобы выжить в условиях сокращающегося спроса, производители были вынуждены усилить борьбу за потребителя.

Заметим, что в первую очередь кризис спровоцировал уход с рынка неопытных пользователей (табл. 6). Т. е., доля компетентных потребителей увеличилась, причем в некоторых сегментах довольно значительно, и конкуренция обострилась в первую очередь за них.

Напомним, что опытные заказчики в меньшей степени подвержены эффекту «мутного стекла» и, соответственно, способны четче дифференцировать предлагаемые услуги [Дорошенко, 2010]. Поэтому, в отличие от неопытных потребителей, выбирающих поставщика в первую очередь по критерию низкой цены, опытные пользователи ценят качественные

\section{Табл. 5. Доля интеллектуальных услуг, оказываемая на условиях аутсорсинга: 2007 (\%)}

\begin{tabular}{|l|c|c|}
\hline & $\begin{array}{c}\text { Услуги, про- } \\
\text { изводимые } \\
\text { внутрени- } \\
\text { ми подраз- } \\
\text { делениями } \\
\text { компаний }\end{array}$ & $\begin{array}{c}\text { Услуги, при- } \\
\text { обретаемые } \\
\text { у внешних } \\
\text { исполителей }\end{array}$ \\
\hline Услуги рекламы & 72.2 & 27.8 \\
\hline Маркетинговые услуги & 84.0 & 16.0 \\
\hline ІТ-услуги & 86.1 & 13.9 \\
\hline Аудиторские услуги & 84.4 & 15.6 \\
\hline $\begin{array}{l}\text { Услуги по подбору } \\
\text { персонала }\end{array}$ & 87.4 & 12.6 \\
\hline $\begin{array}{l}\text { Инжиниринговые } \\
\text { услуги }\end{array}$ & 94.0 & 6.0 \\
\hline Юридические услуги & 91.0 & 9.0 \\
\hline Дизайнерские услуги & 90.6 & 9.4 \\
\hline Риэлторские услуги & 94.0 & 6.0 \\
\hline $\begin{array}{l}\text { Услуги финансового } \\
\text { посредничества }\end{array}$ & 83.8 & 16.2 \\
\hline $\begin{array}{l}\text { Средневзвешенная } \\
\text { по сектору }\end{array}$ & 86.7 & 13.3 \\
\hline
\end{tabular}

характеристики услуги, в том числе ее клиентоориентированность, адаптированность под свои конкретные нужды (табл. 7).

Следовательно, чтобы удовлетворять запросам опытного потребителя, необходимо максимально индивидуализировать предоставляемую ему услугу. Процесс разработки подобной услуги представляет собой генерирование как минимум продуктовой (а часто еще и организационной, и маркетинговой) инновации. В связи с этим инновационная активность рассматривалась производителями интеллектуальных услуг как важное, если не главное, условие выживания во время кризиса (табл. 8).

В итоге только 3\% компаний могут функционировать, не осуществляя инноваций. Еще 7\% прекратили инновационную деятельность вынужденно, под влиянием кризиса (видимо, пытаясь удержать неопытных потребителей или, напротив, надеясь привлечь их за счет снижения цены услуг). Десятая часть компаний сократила инновационную активность, но не смогла полностью от нее отказаться. При этом 26\%, напротив, ее увеличили, а 12\% объявили инновации главным средством выхода из кризиса. В последней группе особо выделяются производители услуг в области дизайна и ИКТ, чья зависимость от инновационной составляющей в период кризиса оказалась вдвое выше среднего значения.

Сравнивая приведенные данные с показателями других отраслей, многие из которых во время кризиса сократили инновационную деятельность (табл. 3), можно констатировать, что кризис стимулировал и без того высокую склонность производителей услуг к инновациям. Оставшись без поддержки государства, эти компании были вынуждены мобилизировать внутренние конкурентные преимущества, среди которых инновации играют важную, а иногда и ключевую роль, особенно в борьбе за опытных потребителей. Таким образом, кризис способствовал реализации инновационного потенциала сектора интеллектуальных услуг.

\section{Табл. 6. Доля опытных потребителей до кризиса и в настоящее время, по оценке производителей интеллектуальных услуг (\%)}

\begin{tabular}{|l|c|c|}
\hline \multirow{2}{*}{$\begin{array}{l}\text { Маркетинговые } \\
\text { услуги }\end{array}$} & \multicolumn{2}{|c|}{ Доля опытных потребителей } \\
\hline До кризиса & В настоящее время \\
\hline Рекламные услуги & 39.0 & 41.5 \\
\hline Аудиторские услуги & 52.4 & 56.9 \\
\hline Услуги в области ИКТ & 44.0 & 51.4 \\
\hline $\begin{array}{l}\text { Инжиниринговые } \\
\text { услуги }\end{array}$ & 45.7 & 53.7 \\
\hline $\begin{array}{l}\text { Услуги по подбору } \\
\text { персонала }\end{array}$ & 47.4 & 44.9 \\
\hline $\begin{array}{l}\text { Дизайнерские услуги } \\
\text { Услуги в области } \\
\text { недвижимости }\end{array}$ & 49.7 & 47.8 \\
\hline $\begin{array}{l}\text { Услуги финансового } \\
\text { посредничества }\end{array}$ & 36.1 & 53.6 \\
\hline Юридические услуги & 47.5 & 50.5 \\
\hline $\begin{array}{l}\text { Средневзвешенная } \\
\text { по сектору }\end{array}$ & 44.0 & 46.3 \\
\hline
\end{tabular}


Табл. 7. Основные детерминанты спроса на интеллектуальные услуги у различных групп потребителей (\%)

\begin{tabular}{|l|r|}
\hline \multicolumn{2}{|c|}{ Опытные потребители } \\
\hline Качество услуг \\
\hline Репутация исполнителя & 32.2 \\
\hline Цена услуг & 28.3 \\
\hline Опыт работы исполнителя & 22.2 \\
\hline \multicolumn{2}{|c|}{ Неопытные потребители } \\
\hline Цена услуг \\
\hline Репутация исполнителя \\
\hline Реклама \\
\hline Способность соблюдать сроки & 66.0 \\
\hline
\end{tabular}

* В обоих случаях представлены четыре варианта, получившие наибольший процент ответов.

\section{Обратное влияние сервисных инноваций на секторы, потребляющие интеллектуальные услуги}

Не следует, однако, думать, что инновационный по тенциал сектора исчерпывается исключительно инновационной деятельностью компаний-производителей. Сектор интеллектуальных услуг выполняет еще одну важную функцию, способствуя увеличению склонности к инновациям у потребителей. Происходит это вследствие повышения компетентности заказчиков в процессе пользования услугами. Мы выделяем два источника роста компетенций: обучение на опыте и обучение на ошибках. Оба процесса описаны в экономической литературе, но, насколько нам известно, никогда не изучались применительно к кастомизированному производству.

\section{Обучение на опыте сопроизводства услуг}

Важным каналом, через который осуществляется влияние компаний, производящих услуги, на потребляющие, является сопроизводство, или совместное производство. Общеизвестно, что производитель способен оказать интеллектуальную услугу, адаптированную к индивидуальным запросам клиента (т. е., фактически произвести услугу специально под заказчика), только обладая полной информацией о потребителе, что неправдоподобно, поскольку знать абсолютно все относительно другого субъекта невозможно. В свою очередь, неполнота информации исключает полноценную адаптацию. Так, П. ден Хертог прямо указывает, что потребление интеллектуальных услуг не отделимо от их производства, ведь сама их природа требует хорошего знания не потребителя вообще, а конкретного пользователя, а таким знанием никто, кроме него самого, не располагает [den Hertog, 2000].

Как следствие, для индивидуализации услуги клиент должен стать ее «сопроизводителем», предоставив ключевой ресурс - информацию. Поэтому у сервисных инноваций кастомизированного типа не один «автор», а два: собственно фирма, оказывающая услугу и использующая свой интеллектуальный ресурс, который можно назвать квалифицированным трудом, и потребитель услуги, вкладывающий информационный ресурс. Происходит, как принято называть этот процесс в литературе, «интеграция внешнего реcypca» [Marík et al., 2002; Gassmann et al., 2007; и др.]. Необходимость функциональной интеграции «производителя» и «потребителя» интеллектуальной услуги настолько существенна, что в ряде исследований предлагается говорить о совместном производстве, или «сопроизводстве», услуги [Miles et al., 1994; Sundbo, Gallouj, 2000; и др.]. Активное сопроизводство даже определяют, как «природу» интеллектуальной услуги [Vargo, Lusch, 2004], имея в виду, что без сопроизводства услуга может быть только стандартной, а не кастомизированной. Индивидуализировать природу услуги возможно лишь посредством сопроизводства.

Поскольку доля индивидуализированных услуг в России довольно велика, то и уровень сопроизводства тоже высок. Этот показатель замеряется в ходе наших опросов ежегодно и не опускается ниже 6 баллов из 10. В период кризиса заметного изменения уровня сопроизводства не произошло, так как потребность в индивидуализированных услугах выросла. Как показано в табл. 9, и в 2007, и в 2010 гг. деятельность по оказанию интеллектуальных услуг отличалась активным сопроизводством.

По полученным в ходе обследования данным, средняя степень вовлеченности и до кризиса, и в настоящее время превышает 6 баллов из 10. Это означает, что заказчики действительно принимают активное участие в производстве предназначенных для них услуг. При

Табл. 8. Изменение инновационной политики производителей интеллектуальных услуг в период кризиса (\% от общего числа опрошенных)

\begin{tabular}{|c|c|c|c|c|c|c|c|c|c|c|c|}
\hline & 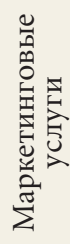 & 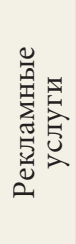 & 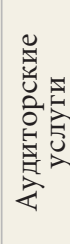 & 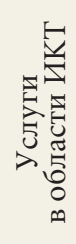 & 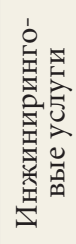 & 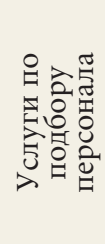 & 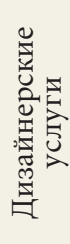 & 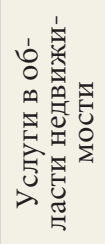 & 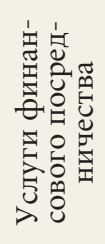 & 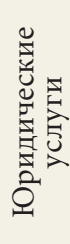 & 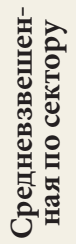 \\
\hline Инновации исключены из числа приоритетов & 8.3 & 6.7 & 11.7 & 6.7 & 4.9 & 12.1 & 6.8 & 8.6 & 3.4 & 3.4 & 7.2 \\
\hline Значимость инноваций уменьшилась & 8.3 & 3.3 & 13.3 & 13.3 & 13.1 & 12.1 & 5.1 & 10.3 & 15.3 & 13.6 & 10.8 \\
\hline Инновационная политика осталась без изменений & 26.7 & 40.0 & 45.0 & 28.3 & 37.7 & 41.4 & 32.2 & 55.2 & 54.2 & 42.4 & 40.2 \\
\hline Значимость инноваций выросла & 40.0 & 30.0 & 15.0 & 25.0 & 32.8 & 27.6 & 33.9 & 17.2 & 18.6 & 22.0 & 26.3 \\
\hline $\begin{array}{l}\text { Инновации признаны основным средством выхода } \\
\text { из кризиса }\end{array}$ & 6.7 & 13.3 & 8.3 & 25.0 & 9.8 & 5.2 & 22.0 & 5.2 & 8.5 & 18.6 & 12.3 \\
\hline Инновации не внедряются & 10.0 & 5.0 & 6.7 & 1.7 & 1.6 & 1.7 & 0.0 & 3.4 & 0.0 & 0.0 & 3.0 \\
\hline
\end{tabular}


Табл. 9. Уровень сопроизводства интеллектуальных услуг в России (\%)

\begin{tabular}{|c|c|c|}
\hline & \multicolumn{2}{|c|}{$\begin{array}{c}\text { Степень вовлеченности } \\
\text { заказчика в } \\
\text { производство услуги }\end{array}$} \\
\hline & 2007 & 2010 \\
\hline Маркетинговые услуги & 6.3 & 5.7 \\
\hline Рекламные услуги & 5.6 & 6.1 \\
\hline Аудиторские услуги & 5.6 & 5.8 \\
\hline Услуги в области ИКТ & 6.5 & 7.2 \\
\hline Инжиниринговые услуги & 5.7 & 4.4 \\
\hline Услуги по подбору персонала & 6.2 & 5.7 \\
\hline Дизайнерские услуги & 6.1 & 6.8 \\
\hline $\begin{array}{l}\text { Услуги в области } \\
\text { недвижимости }\end{array}$ & 5.2 & 5.9 \\
\hline $\begin{array}{l}\text { Услуги финансового } \\
\text { посредничества }\end{array}$ & 7.0 & 7.2 \\
\hline Юридические услуги & 6.4 & 7.2 \\
\hline $\begin{array}{l}\text { Средневзвешенная по } \\
\text { сектору }\end{array}$ & 6.1 & 6.2 \\
\hline
\end{tabular}

* Респондентам предлагалось оценить степень участия заказчика в производстве услуги по 10-балльной шкале, где 1 - грамотная постановка задачи и полное самоустранение до момента приемки готовой работы, а 10 - полное вовлечение, постоянное взаимодействие, совместная реализация проекта.

создании полностью индивидуальной услуги фактически осуществляется совместное производство продуктовой инновации заказчиком и исполнителем, говорят даже о «совместном изобретении» (co-invention) такой услуги [Bresnahan, 2002].

В процессе сопроизводства потребитель оказывается активно вовлеченным в разработку сервисной инновации. Понятно, что подобная деятельность является для него непрофильной, т. е., специальной подготовки в данной области представители заказчика обычно не имеют. В специфику производства услуг приходится втягиваться «на ходу». Такой процесс называется, как известно, обучением на опыте (learning by doing).

Со времен хрестоматийной статьи нобелевского лауреата Кеннета Эрроу [Arrow, 1962], который ввел в научный оборот понятие learning by doing, процесс обучения на опыте рассматривается как важнейший источник повышения производительности, который внедряется в самые разные производственные функции. До сих пор в таких функциях фигурировал только один производитель - фирма, выпускающая товар или услугу. Однако в производстве интеллектуальных услуг участвуют две компании исполнитель и заказчик. Что же означает обучение на опыте для потребителя-сопроизводителя?

Во-первых, качественное сопроизводство делает услугу продуктовой инновацией, его отсутствие позволяет получить только стандартную - неинновационную - услугу. Таким образом, опыт потребления способствует улучшению самого потребляемого продукта! Этим кардинально отличается результат потребительского опыта в секторе интеллектуальных услуг. Конечно, в любой сфере опытный потребитель имеет преимущество перед неопытным с точки зрения способности к абсорбции инноваций — он лучше понимает и распознает ценность нового, в большей степени способен извлекать для себя пользу из новизны покупаемого предмета. Однако повышенная абсорбционная способность дает возможность всего лишь лучше bыбирать; сам ассортимент товаров от этого не меняется, по крайней мере, мгновенно. В самом деле, какой бы продвинутый пользователь ни пришел в салон мобильной связи, он может только правильно выбрать телефон, но его опыт ни на йоту не изменит качество и возможности лежащих на витрине аппаратов. Ведь покупатель не имеет отношения к производству телефонов. В лучшем случае его мнение каким-либо образом будет учтено при совершенствовании телефонов в будущем.

Но интеллектуальную услугу кастомизированного характера невозможно выбрать из готового ассортимента, ее надо изобрести вместе с производителем. Поэтому опыт потребителя помогает лучше произвести услугу. Learning by doing дает возможность в конце сопроизводства получить лучшую услугу, нежели в начале. Следовательно, опыт потребления услуги совершенствует сам приобретаемый продукт, повышает уровень его инновационности.

Но этим дело не ограничивается. Второй, не менее существенный результат наращивания опыта состоит в том, что у пользователя возрастает склонность к аутсорсингу производства интеллектуальных услуг.

Поясним подробнее. В предыдущем разделе указывалось, что приобретение интеллектуальных услуг не является непременным атрибутом современной компании. Практически любая фирма имеет отделы (непрофильные), которые занимаются «внутренним производством» соответствующих услуг для профильных подразделений ${ }^{2}$. Например, отдел маркетинга замещает услуги специализированных маркетинговых компаний, кадровая служба - услуги по подбору персонала и т. п.

Но если бы собственные подразделения могли полностью удовлетворить нужды основного производства, то необходимость внешних интеллектуальных услуг вообще бы отсутствовала. Однако она имеется, следовательно, производимые внутренними подразделениями услуги не являются совершенным субститутом внешних услуг. По-видимому, причина в том, что сервисная активность в целом ряде случаев требует продвинутых знаний и навыков, приобретение которых означает либо наем дорогостоящих специалистов, либо затратную подготовку своих сотрудников.

Вследствие сказанного можно предположить, что собственным непрофильным подразделениям фирмы поручают рутинную деятельность, которая не характеризуется особой знаниеемкостью и не требует принятия нестандартных решений. Сложные услуги со значительной интеллектуальной составляющей выгоднее передавать на аутсорсинг.

Строго говоря, термин «внутреннее производство услуг» является не вполне корректным, так как «услуга» подразумевает, что соответствующая деятельность осуществляется на платной основе. Однако сектор интеллектуальных услуг — сравнительно новый объект исследования и относящаяся к нему терминология пока не вполне сложилась. Поэтому мы пока будем использовать вышеуказанное словосочетание. 
Почему ваша компания не передает оказание услуг внешним компаниям полностью?

\section{Типовые задачи решаем самостоятельно \\ Услуги сторонних организаций дороже}

Необходимы знания, которыми не располагают внешние исполнители

Выполнить ряд услуг самостоятельно легче

Некоторые услуги сторонние компании не оказывают

Основная масса информации о компании конфиденциальна

Иногда нет времени на поиски сторонних организаций

Качество выполнения данных услуг нашей компанией выше

Наша компания выполняет эту работу быстрее
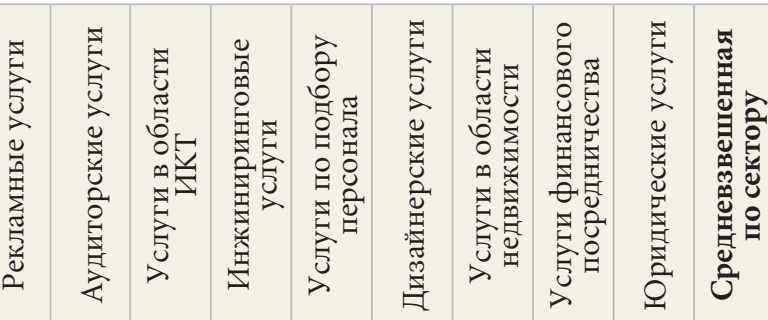

\begin{tabular}{|l|l|l|l|l|l|l|l|l|l|l|}
56.9 & 58.3 & 81.2 & 82.4 & 78.6 & 63.2 & 67.7 & 60.0 & 76.3 & 70.2 & $\mathbf{6 9 . 8}$ \\
\hline
\end{tabular}

\begin{tabular}{|l|l|l|l|l|l|l|l|l|l|l|l|}
19.3 & 27.6 & 15.3 & 20.6 & 14.3 & 31.6 & 27.4 & 10.0 & 18.4 & 23.4 & 21.1
\end{tabular}

\begin{tabular}{|l|l|l|l|l|l|l|l|l|l|l|}
11.0 & 12.6 & 5.9 & 2.9 & 7.1 & 7.9 & 9.7 & 20.0 & 18.4 & 6.4 & $\mathbf{9 . 9}$ \\
\hline
\end{tabular}

\begin{tabular}{|l|l|l|l|l|l|l|l|l|l|l|}
\hline 9.2 & 11.6 & 1.2 & 8.8 & 7.1 & 5.3 & 9.7 & 10.0 & 5.3 & 12.8 & 7.9 \\
\hline
\end{tabular}

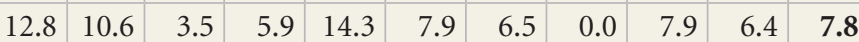

\begin{tabular}{|l|l|l|l|l|l|l|l|l|l|l|}
\hline 17.4 & 7.0 & 4.7 & 0.0 & 0.0 & 18.4 & 1.6 & 0.0 & 10.5 & 10.6 & 7.3 \\
\hline
\end{tabular}

\begin{tabular}{|l|l|l|l|l|l|l|l|l|l|l|}
7.3 & 3.5 & 1.2 & 2.9 & 7.1 & 10.5 & 6.5 & 0.0 & 0.0 & 6.4 & $\mathbf{4 . 6}$ \\
\hline
\end{tabular}

\begin{tabular}{|l|l|l|l|l|l|l|l|l|l|l|}
\hline 8.3 & 3.5 & 2.4 & 5.9 & 0.0 & 5.3 & 3.2 & 0.0 & 5.3 & 0.0 & 3.6 \\
\hline
\end{tabular}

\begin{tabular}{|l|l|l|l|l|l|l|l|l|l|l|}
\hline 4.6 & 2.0 & 0.0 & 5.9 & 7.1 & 2.6 & 3.2 & 0.0 & 2.6 & 4.3 & 3.3 \\
\hline
\end{tabular}

* Сумма по столбцам превышает 100\%, т. к. респонденты могли выбирать до трех ответов.

В нашем эмпирическом исследовании 2010 г. это предположение подтвердилось (табл. 10): стремле ние решать типовые задачи самостоятельно с большим отрывом доминировало среди прочих причин производства услуг своими силами.

Отметим и то, что потребители не преувеличивают собственную способность произвести услуги лучше, легче и/или быстрее - таковых в общей сложности не более 15\%. Интересно, что до кризиса доля производителей, отказывающихся от аутсорсинга, «потому что мы способны все это сделать сами», была почти в два раза выше (28.1\%). Это еще раз подтверждает, что в период кризиса рынок покинули преимущественно неопытные пользователи, обращавшиеся к стандартным услугам, оказание которых не требует высокой квалификации, - такие, наверно, действительно можно произвести собственными силами.

Опытные потребители, заказывающие более индивидуализированные услуги, в ходе неизбежно активного в подобных случаях сопроизводства усвоили, что разработка и реализация сервисных инно-

\begin{tabular}{|c|c|}
\hline & $\begin{array}{l}\text { Доля услуг, передаваемых } \\
\text { на внешнее исполнение }\end{array}$ \\
\hline $\begin{array}{l}\text { Опытные } \\
\text { пользователи }\end{array}$ & 37.5 \\
\hline $\begin{array}{l}\text { Неопытные } \\
\text { пользователи }\end{array}$ & 22.7 \\
\hline $\begin{array}{l}\text { Средневзвешенное } \\
\text { значение }\end{array}$ & 29.3 \\
\hline
\end{tabular}

\section{Примечания:}

1. Расчеты производились только для респондентов, указавших свою потребность в соответствующих услугах

2. В качестве весов при расчете средневзвешенных величин использовались доли респондентов, входящих в соответствующую группу, без учета затруднившихся ответить. ваций - совсем не простое занятие. Соответственно, с опытом сопроизводства растет понимание того, что сложные знаниеемкие услуги лучше передавать высококвалифицированному персоналу сторонних компаний. Тем самым, learning by doing в потреблении расширяет спрос на интеллектуальные услуги за счет повышения склонности к аутсорсингу. Действительно, при углубленном анализе уровень внутреннего производства в 2010 г. для опытных и неопытных пользователей оказался неодинаков (табл. 11). Опытные пользователи удовлетворяют свою потребность в интеллектуальных услугах значительно активнее, чем неопытные. Уровень аутсорсинга услуг у опытных потребителей на треть выше.

Третий эффект, влияющий на компетентность потребителей услуг через сопроизводство, состоит в том, что они втягиваются в непрофильную для себя активность и поневоле приобретают знания, не связанные с основной деятельностью.

Как показали исследования, заказчик, особенно не обладающий большим опытом потребления интеллектуальных услуг, может и сам до конца не знать, что ему нужно. У него существует лишь общее представление о желаемой услуге: «Мне нужно разработать маркетинговую кампанию для нового продукта», или: «Нам требуются кандидатуры на должность менеджера проекта». Понятно, что таких расплывчатых сведений недостаточно для оказания индивидуализированной услуги. Процесс уточнения исполнителем потребностей заказчика может происходить в течение всего периода совместной работы. В итоге информированность и грамотность заказчика возрастают по нескольким причинам.

1. В ходе взаимодействия с исполнителем заказчик начинает лучше разбираться в себе и своих потребностях. Типичная реакция на вопросы производителя услуги: «Я об этом никогда раньше 
Табл. 12. Влияние опыта на качество сопроизводства интеллектуальных услуг: мнение потребителей (\% от общего числа опрошенных)

\begin{tabular}{|l|c|c|c|c|c|c|}
\hline $\begin{array}{l}\text { По мере работы с исполнителем, } \\
\text { становитесь ли вы более } \\
\text { квалифицированным сопроизводителем? }\end{array}$ & Да & $\begin{array}{c}\text { Скорее } \\
\text { да, чем } \\
\text { нет }\end{array}$ & Иногда & $\begin{array}{c}\text { Скорее } \\
\text { нет, чем } \\
\text { да }\end{array}$ & $\begin{array}{c}\text { Нет } \\
\text { Затрудняюсь } \\
\text { ответить }\end{array}$ \\
\hline Маркетинговые услуги & 24.8 & 32.2 & 19.0 & 3.3 & 5.8 & 14.9 \\
\hline Рекламные услуги & 21.8 & 19.2 & 25.3 & 6.1 & 5.7 & 21.8 \\
\hline Аудиторские услуги & 26.9 & 22.6 & 24.7 & 7.5 & 5.4 & 12.9 \\
\hline Услуги в области ИКТ & 25.0 & 11.1 & 16.7 & 13.9 & 16.7 & 16.7 \\
\hline Инжиниринговые услуги & 11.8 & 23.5 & 17.6 & 11.8 & 5.9 & 29.4 \\
\hline Услуги по подбору персонала & 21.4 & 14.3 & 31.0 & 4.8 & 14.3 & 14.3 \\
\hline Дизайнерские услуги & 28.9 & 23.7 & 21.1 & 6.6 & 1.3 & 18.4 \\
\hline Услуги в области недвижимости & 0.0 & 6.3 & 25.0 & 18.8 & 18.8 & 31.3 \\
\hline Услуги финансового посредничества & 19.0 & 16.7 & 11.9 & 14.3 & 9.5 & 28.6 \\
\hline Юридические услуги & 29.3 & 12.1 & 19.0 & 8.6 & 6.9 & 24.1 \\
\hline Всего & $\mathbf{2 0 . 9}$ & $\mathbf{1 8 . 2}$ & $\mathbf{2 1 . 1}$ & $\mathbf{9 . 6}$ & $\mathbf{9 . 0}$ & 21.2 \\
\hline
\end{tabular}

не задумывался». Практика свидетельствует, что многие, даже опытные заказчики, на начальном этапе взаимодействия полностью не осознают, что им действительно нужно.

2. Заказчик больше узнает об особенностях производства услуги, получая при этом непрофильные знания. Дизайнерам приходится посвящать клиентов в закономерности цветового восприятия, юристам - в нюансы законодательства, производителям инжиниринговых услуг - в технические спецификации и т. п.

3. В процессе общения со специалистами в области оказания услуг заказчик нередко узнает о новых возможностях, о которых ранее не имел представления либо их недооценивал. Например, финансовый посредник, помимо вложений денег в стандартные портфели ценных бумаг, осуществляет и индивидуальное управление средствами; кадровое агентство не просто подбирает подходящую кандидатуру, но и предлагает альтернативные формы найма (аутстаффинг и т. п.).

4. Заказчик может выдвигать и невыполнимые условия. Случается, что девелоперам предлагают разработать проект с нарушением правил землепользования, от инжиниринговых компаний требуют технически некорректных решений и т. п. Узнав об этом, потребитель учится правильнее

Табл. 13. Доля заказчиков, улучшающих свою квалификацию в процессе

сопроизводства: мнение производителей (\% от общего числа опрошенных)

\begin{tabular}{|l|l}
\hline Услуги рекламы & 48.3 \\
\hline Маркетинговые услуги & 38.8 \\
\hline Услуги в области ИКТ & 46.7 \\
\hline Аудиторские услуги & 57.5 \\
\hline Услуги по подбору персонала & 34.4 \\
\hline Инжиниринговые услуги & 52.9 \\
\hline Юридические услуги & 64.6 \\
\hline Дизайнерские услуги & 50.0 \\
\hline Услуги в области операций с недвижимостью & 58.1 \\
\hline Услуги финансового посредничества & 53.3 \\
\hline Средневзвешенная по сектору & $\mathbf{5 0 . 5}$
\end{tabular}

соразмерять свои желания с возможностями, что делает его более грамотным сопроизводителем.

Существуют и другие пути повышения компетенций заказчика, но указанные четыре представляются важнейшими. Это подтверждают и данные опроса, в ходе которого с вышеприведенными утверждениями согласились большинство производителей.

Таким образом, участие в сопроизводстве услуги повышает квалификацию самого заказчика. Последний начинает, во-первых, лучше осмыслять собственную деятельность, во-вторых, приобретает знания из смежных областей, в-третьих, становится более восприимчивым к инновациям, особенно если осуществляет сопроизводство услуг с разными производителями, т. е. учится усваивать и использовать разнообразные новшества. Этот опыт повышает способность к абсорбции не только услуг, но и других инноваций.

В то же время сказанное не означает, что «апгрейд» потребителей происходит легко и как бы автоматически. На самом деле, повышение квалификации задача трудоемкая, требующая усилий, и заказчики интеллектуальных услуг не являются исключением. То есть рост производительности труда потребителей (сопроизводителей) не является обязательным следствием заказа услуги. Для проверки этой гипотезы мы задали симметричные вопросы производителям и потребителям услуг. Ответы приведены в табл. 12 и 13.

Почти каждый пятый уверен, что не совершенствуется в процессе производства услуги, еще $18 \%$ полагают, что сопроизводство бывает полезно лишь эпизодически. Интересно, что в сумме эти две цифры (39.7\%) мало отличаются от доли неопытных заказчиков (43.4\%), что неудивительно: в случае стандартных услуг сопроизводство не требуется либо необходимо в минимальном объеме. Странно было бы ожидать при этом повышения квалификации потребителей.

В повышении своей компетентности как заказчика уверены чуть более трети опрошенных (несмотря на то, что удельный вес опытных потребителей среди них составляет 56.6\%). Примечательна и зна- 
чительная доля затруднившихся ответить (свыше $20 \%)$, тогда как на другие вопросы обычно не от вечает в среднем 5-8\% респондентов. Мы не склонны считать, что это вызвано сложностью вопроса. Скорее всего, сопроизводство, с которым столкну лись опытные пользователи, оказалось непростым и не все сумели с ним надлежащим образом справиться, отсюда и сомнения в собственной успешности. О том же свидетельствуют и мнения производителей относительно роста способностей к сопроизводству со стороны заказчиков (табл. 13).

Примерно половина потребителей становятся более квалифицированными сопроизводителями, это не завышенная самооценка, как можно было бы ожидать исходя из данных, представленных в табл. 12, а результат обучения на опыте.

\section{Обучение на ошибках в потреблении услуг}

Термин «обучение на ошибках» активно используется в широчайшем пласте литературы, посвященной формированию ожиданий экономических агентов. Его суть заключается в том, что субъекты, замечая разницу между ожидаемым и реальным значениями какого-либо показателя, стремятся скорректировать свои ожидания. При этом предполагается, что фактическое положение они изменить не в силах.

В нашем случае мы также предполагаем, что расхождение между ожидаемым и фактическим результатами потребления услуги побуждает заказчика пересмотреть свое поведение. Но корректировка в рассматриваемом случае не сводится исключительно к ослаблению завышенных ожиданий, поскольку потребители интеллектуальных услуг, как показало наше исследование, довольно активно пытаются повлиять и на саму эффективность использования услуг.

O том, что завышенные ожидания компаниизаказчика относительно полезности интеллектуальных услуг существуют, свидетельствуют данные об ограниченной способности правильно воспользоваться уже произведенной и оплаченной услугой. До кризиса это было актуально по отношению к каждой второй компании-потребителю: лишь половина из них признавали, что сумели полностью внедрить результаты оказанных услуг. Основные причины возникновения подобных ошибок приведены в табл. 14 .
К числу объективных факторов относятся плохая адаптация услуги к нуждам конкретного потребителя и отсутствие у заказчиков необходимой квалификации. Первый является следствием недостаточно высокого качества сопроизводства и подробно рассмотрен в предыдущем параграфе, в то время как второй создает затруднения с применением уже готовых результатов почти у половины исследуемых сегментов. Примеров множество. Даже грамотно подобранный кадровым агентством сотрудник не сможет трудиться качественно, если его не ознакомить со спецификой новых обязанностей быстро и эффективно. Полезность прекрасно разработанной компьютерной программы будет ограниченной, если пользователь освоит лишь отдельные ее возможности. От технически грамотного консультирования будет мало прока при низкой квалификации строителей и монтажников и т. п. С подобного рода проблемами хоть раз сталкивался почти каждый из опрошенных представителей компаний - производителей услуг.

Потребители тоже признают наличие сложностей с внедрением услуги, но не могут оперативно изменить ситуацию. Ключевым фактором в этом случае также становится опыт, только не положительный сопроизводства, а негативный - ошибок.

Во-первых, заказчик должен осознать проблему полноценного применения результатов. Неопытный пользователь вряд ли догадается об этом заранее: он считает услуги типовыми, а опыт потребления других стандартных благ вряд ли был сопряжен с трудностями. Действительно, что может помешать воспользоваться услугами, например, транспорта или кафе? Были бы деньги и желание. Поэтому распознать интеллектуальную услугу как нечто более сложное для применения неопытный потребитель не сможет. Пока отсутствует практика, заказчик будет считать, что с применением услуги справится любой его сотрудник, поскольку никаких особых компетенций для этого не нужно. И только неудачный опыт абсорбции показывает, что внедрение интеллектуальных услуг требует квалификации.

Во-вторых, идентифицировав проблему, необходимо понять, что требуется для ее решения. Даже

\section{Табл. 14. Причины неполного использования результатов оказания}

интеллектуальных услуг с точки зрения производителей (\% от общего числа опрошенных)

Не удалось учесть потребности конкретной компании-заказчика

Услуга была заказана впрок/на всякий случай

Соответствующим подразделениям компаниизаказчика не хватило квалификации

Руководство компании-заказчика не отслеживало, внедрена ли услуга

Прочее

\section{范}

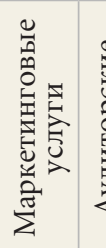

入
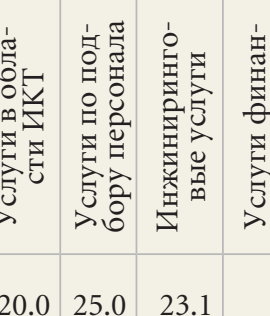

\begin{tabular}{|l|l}
16.7 & 21.1 \\
33.3 & 31.6
\end{tabular}

1.1

0.0

20.025 .0

38.1

\begin{tabular}{l|l}
41.7 & 20.0 \\
\hline 41.7 & 60.0
\end{tabular}

41.760 .0

:

21.127 .3

\begin{tabular}{|l|l|l|}
\hline 40.0 & 20.0 & 38.5 \\
\hline & & \\
\hline
\end{tabular}

\begin{tabular}{l|l}
$8.3 \quad 0.0$ \\
\hline
\end{tabular}

9.1

$10.0 \quad 19.4$

\begin{tabular}{|l|l|l|l|}
\hline 5.6 & 15.8 & 54.5 & 13. \\
\hline
\end{tabular}

$20.0 \quad 25.0 \quad 23.1$

23.1

\begin{tabular}{|l|l|l|}
\hline 13.3 & 25.0 & 7.7 \\
\hline
\end{tabular}

\begin{tabular}{l|l}
8.3 & 20.0
\end{tabular}

9.110 .0

\begin{tabular}{ll}
35.8 \\
\hline
\end{tabular}

\begin{tabular}{|l|l|l|l|l|l|}
\hline 16.7 & 10.5 & 9.1 & 6.7 & 5.0 & 7.7 \\
\hline
\end{tabular}

\begin{tabular}{l|r}
0.0 & 0.0
\end{tabular}

\begin{tabular}{|l|l|l|}
0.0 & 30.0 & 17.2 \\
\hline
\end{tabular}

7.7 
если вследствие неудачной попытки заказчику станет понятно, что работники соответствующих подразделений его компании не смогли надлежащим образом распорядиться тем, что предоставили им производители услуг, это не значит, что он сразу сможет определить, каких именно компетенций им не достает. Если потребитель неопытный, следовательно, он пользовался только типовыми услугами, которые, скорее всего, и производил, и внедрял персонал его собственных подразделений. На эту работу подбирали людей с квалификацией, необходимой для применения типового блага, но недостаточной, чтобы воспользоваться инновацией. Однако каких именно компетенций недостает, с первого раза может быть и не очевидно. Для выявления всех необходимых знаний и умений требуется более широкий опыт потребления услуг.

В-третьих, осознав, что нужно для решения проблемы, следует выбрать способ ее решения. Даже четкое понимание того, каких именно компетенций не хватает сотрудникам для полного внедрения результатов оказанных услуг, не приведет к их автоматическому появлению. Знания и умения не приходят сами, их нужно целенаправленно формировать. Наверно, в какой-то степени можно рассчитывать на самообразование работников, но лишь до определенных пределов. Значит, надо либо искать пути наращивания компетентности на основе аутсорсинга, т. е. отправить сотрудников на курсы повышения квалификации или организовать обучение на рабочем месте, либо нанять новых специалистов с лучшей подготовкой. Любой из способов требует времени и денежных затрат. Но главное образование относится к категории доверительных благ: наниматель не может быть уверен, что приобретенные компетенции прежних сотрудников или знания новых достаточны для эффективного использования услуг. По свидетельству экспертов, встречались случаи, когда поиск и/или обучение сотрудников происходили в несколько итераций, методом последовательных приближений, по мере накопления опыта.

Без практики потребления сложно распознать, оценить и полноценно решить проблему недостаточной квалификации сотрудников заказчика, ответственных за внедрение услуг. Поэтому перечисленные «лакуны» устраняются постепенно, в процессе обучения на ошибках пользования услугами. Результатом такого обучения для компаниизаказчика становится повышение инновационности благодаря улучшению качества персонала, совершенствованию уровня его компетенций.

Отметим еще один аспект влияния обучения на ошибках, затрагивающий не исполнительский персонал, а, скорее, менеджмент компанийпотребителей. В табл. 14 показано, что более трети заказчиков приобретали услуги, которые были по большому счету им не нужны, а еще $17 \%$ не слишком следили за использованием результатов. До кризиса подобная ситуация была достаточно распространенной. В условиях бурного роста конъюнктурных доходов многие потребители заказывали услуги, что называется, «впрок», «на всякий случай», «имитируя бурную деятельность», «чтобы выглядеть не хуже других» и т. п. Кроме того, заказывает услугу обычно руководитель компании, а использовать ее результаты поручает подчиненным, с которых потом не слишком строго спрашивает за внедрение приобретенной «на всякий случай» услуги.

Следует отметить, что подобное отношение не является специфичным для России. В развитых странах картина примерно такая же. Так, немецкие специалисты опубликовали в 2009 г. результаты эмпирического исследования, в котором участвовали 272 компании - пользователи интеллектуальных услуг [KIT, 2009]. Обнаружилось, что оценка эффективности использования услуг, как до, так и после завершения проекта, потребителями более чем в половине случаев не ведется. Отсюда видно, что немецкие компании не сильнее российских озабочены эффективностью траты средств на приобретение услуг.

В России обучение менеджмента компанийпотребителей на данном типе ошибок было значительно ускорено кризисом. В поисках путей оптимизации издержек руководители компаний стали заказывать только те услуги, в которых действительно нуждаются. Это побуждает к более тщательному анализу эффективности сервисных инноваций, изучению каналов их влияния на деятельность компании-потребителя, взвешенной оценке собственных абсорбционных способностей.

Одновременно заказчики стали гораздо серьезнее относиться к использованию результатов оказания услуг. По словам экспертов, руководители компаний-потребителей теперь всегда требуют от подчиненных отчета о применении этих результатов, многие разработали систему поощрений к эффективному использованию услуг и наказаний за небрежное отношение к их внедрению.

Таким образом, стремление устранить ошибки руководства, связанные с применением услуг, породило целый ряд управленческих нововведений, которые улучшают общий уровень менеджмента инноваций.

\section{Взаимовлияние инновационности заказчиков и производителей интеллектуальных услуг}

Итак, мы выяснили, что приобретение опыта пользования интеллектуальными услугами способствует росту инновационности заказчика по следующим каналам:

1) Повышается качество и, следовательно, инновационность сопроизводимых и потребляемых заказчиком услуг.

2) У заказчика усиливается склонность к аутсорсингу услуг, благодаря чему средний уровень инновационности используемых им услуг возрастает.

3) Заказчик приобретает опыт усвоения непрофильных инноваций, что увеличивает его способность к абсорбции внешних инноваций в целом. 
Табл. 15. Становится ли заказчик более инновационным, используя результаты оказания интеллектуальных услуг? (\% от общего числа опрошенных)

\begin{tabular}{|l|c|c|}
\hline & Да & Нет \\
\hline Услуги рекламы & 61.2 & 38.8 \\
\hline Маркетинговые услуги & 71.1 & 28.9 \\
\hline Услуги в области ИКТ & 74.5 & 25.5 \\
\hline Аудиторские услуги & 92.7 & 7.3 \\
\hline Услуги по подбору персонала & 51.0 & 49.0 \\
\hline Инжиниринговые услуги & 78.7 & 21.3 \\
\hline Юридические услуги & 92.0 & 8.0 \\
\hline Дизайнерские услуги & 70.6 & 29.4 \\
\hline Услуги в области операций & & \\
\hline с недижимостью & 75.6 & 24.4 \\
\hline Услуги финансового посредничества & 87.3 & 12.7 \\
\hline Средневзвешенная по сектору & 75.9 & 24.1 \\
\hline
\end{tabular}

4) Негативный опыт, когда услуги надлежащего качества не смогли принести пользу компании из-за недостаточных компетенций сотрудников, ответственных за их внедрение, побуждает нанимать более квалифицированный персонал с лучшими способностями к абсорбции инноваций.

5) Стремление исправить ошибки руководства, допускавшего неэффективное приобретение услуг и не осуществлявшего должный контроль за их использованием, повышает общий уровень менеджмента инноваций в компаниях потребителях.

В итоге возникает целая сеть каналов, через которые сервисные инновации (кастомизи- рованные услуги) повышают инновационность своих потребителей, а компании, избравшие дифференцированную стратегию, в случае ее успешного проведения укрепляют и расширяют свою клиентскую базу.

Большинство производителей уверенно утверждают, что приобщение к их услугам делает потребителей более продвинутыми (табл. 15).

Аналогичные эффекты отмечены и зарубежными исследователями, которые приводят многочисленные эмпирические свидетельства того, что сектор интеллектуальных услуг улучшает условия инновационной деятельности и стимулирует научно-технический прогресс [Antonelli, 1998; den Hertog, 2000; Haukness, 2000; Muller, Zenker, 2001; Tether, 2003; Koch, Stahlecker, 2006; Simmie, Strambach, 2006]. Они подчеркивают, что, благодаря участию в производстве и использовании инноваций, происходит «апгрейд» самого заказчика. В этом и заключается обратное влияние сервисных инноваций на сектор-пользователь.

Отметим также общеэкономические эффекты описанных стимулов к инновационному поведению, направленных от производителей интеллектуальных услуг к потребителям. Выше, в первом разделе отмечалось, что тенденция к кастомизации по мере прогресса постиндустриального общества будет нарастать и в других секторах. Причем данный тренд сопряжен не только с технологическими инновациями. Кардинальное изменение характера рынков сбыта обусловливает необходимость внедрения поставщиками индивидуализированной продукции соответствующих организационных, управленче-

Табл. 16. Влияние инновационности заказчика на его потребность в интеллектуальных услугах (\% от общего числа опрошенных)

\begin{tabular}{|c|c|c|c|c|c|c|c|c|c|c|c|}
\hline & 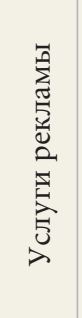 & 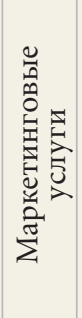 & 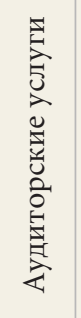 & 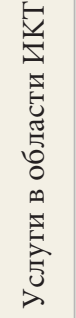 & 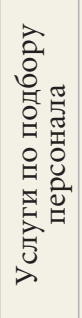 & 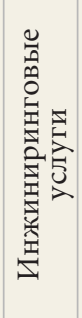 & 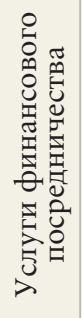 & 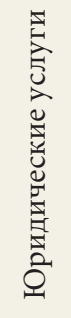 & 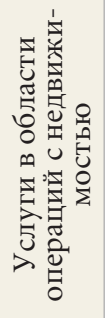 & 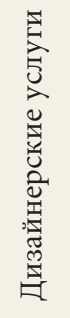 & 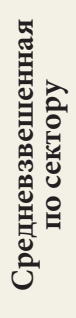 \\
\hline Расширяется ассортимент заказываемых услуг & 32.0 & 42.6 & 25.5 & 50.9 & 53.6 & 41.1 & 45.5 & 25.5 & 31.4 & 30.5 & 38.1 \\
\hline Возрастает интерес к инновационным услугам & 42.0 & 42.6 & 29.8 & 64.9 & 35.7 & 37.5 & 32.7 & 18.2 & 29.4 & 42.4 & 37.8 \\
\hline Увеличивается объем заказываемых услуг & 34.0 & 24.1 & 31.9 & 57.9 & 41.1 & 19.6 & 43.6 & 27.3 & 11.8 & 22.0 & 31.5 \\
\hline $\begin{array}{l}\text { Повышается степень индивидуализации } \\
\text { запрашиваемых услуг }\end{array}$ & 28.0 & 24.1 & 34.0 & 45.6 & 26.8 & 33.9 & 27.3 & 23.6 & 17.6 & 39.0 & 30.2 \\
\hline Увеличивается частота обращения & 20.0 & 29.6 & 36.2 & 43.9 & 21.4 & 16.1 & 21.8 & 14.5 & 43.1 & 22.0 & 26.7 \\
\hline $\begin{array}{l}\text { Растет степень вовлеченности заказчика } \\
\text { в сопроизводство услуг }\end{array}$ & 28.0 & 24.1 & 23.4 & 42.1 & 16.1 & 19.6 & 9.1 & 5.5 & 21.6 & 25.4 & 21.5 \\
\hline Не влияет & 14.0 & 9.3 & 25.5 & 3.5 & 1.8 & 21.4 & 7.3 & 38.2 & 13.7 & 13.6 & 14.6 \\
\hline Снижается степень вовлеченности & 4.0 & 0.0 & 6.4 & 7.0 & 7.1 & 5.4 & 0.0 & 1.8 & 2.0 & 5.1 & 3.9 \\
\hline $\begin{array}{l}\text { Происходит смещение от индивидуальных услуг } \\
\text { к стандартным }\end{array}$ & 6.0 & 5.6 & 12.8 & 3.5 & 1.8 & 1.8 & 3.6 & 3.6 & 0.0 & 1.7 & 3.9 \\
\hline Уменьшается объем заказываемых услуг & 0.0 & 1.9 & 4.3 & 0.0 & 3.6 & 0.0 & 0.0 & 3.6 & 3.9 & 1.7 & 1.9 \\
\hline Снижается частота обращения & 0.0 & 1.9 & 2.1 & 0.0 & 1.8 & 0.0 & 1.8 & 1.8 & 2.0 & 3.4 & 1.5 \\
\hline Сокращается ассортимент & 2.0 & 0.0 & 4.3 & 1.8 & 3.6 & 0.0 & 0.0 & 1.8 & 0.0 & 0.0 & 1.3 \\
\hline Падает интерес к инновационным услугам & 0.0 & 1.9 & 2.1 & 0.0 & 0.0 & 1.8 & 1.8 & 0.0 & 0.0 & 1.7 & 0.9 \\
\hline
\end{tabular}

* Сумма ответов превышает 100\%, так как респонденты выбирали до трех вариантов ответа. 
ских и маркетинговых инноваций, нацеленных на «штучную» работу с конкретным заказчиком. Можно сказать, что переход на постиндустриальные рельсы требует от производителей нового типа мышления.

С точки зрения формирования постиндустриального общества ценность интеллектуальных услуг состоит не только в том, что они становятся очагом масштабного кастомизированного производства, но и в стимулировании развития основ того самого постиндустриального мышления у потребителей, которое может им понадобиться в самом ближайшем будущем. Следовательно, развитие подобных услуг, помимо того что является источником постиндустриального типа экономического роста, еще и улучшает качество прогресса секторов-реципиентов.

Однако влияние сервисных инноваций на потребителей не является однонаправленным. Примечательно то, что заказчик, становясь более инновационным, в свою очередь стремится получить еще более продвинутые услуги. Об этом свидетельствует табл. 16.
Более $80 \%$ производителей утверждают, что с ростом инновационности заказчика увеличивается как ассортимент запрашиваемых услуг, так и частота их использования. Это самый эффективный способ приобретения опыта для потребителя. А опытный пользователь, понимающий и ценящий индивидуальный характер услуг, со своей стороны, стимулирует производителей создавать для него еще более продвинутые услуги, и процесс этот носит самоподдерживающийся характер.

Получается - в положительном смысле - замкнутый круг: пользование инновационными услугами повышает стимулы заказчика к инновациям, а растущая потребность заказчика в инновационных продуктах заставляет создавать более инновационные услуги, что, в свою очередь, усиливает инновационность производителя, и т. д. Неудивительно, что такой самовоспроизводящийся механизм рассматривается во многих странах как важнейший источник устойчивого экономического роста постиндустриального типа.

Дорошенко М.Е. (2007) Интеллектуальные услуги сегодня и завтра // Форсайт. № 2(2). С. 37-45.

Дорошенко М.Е. (2010) Кризисные стратегии в секторе интеллектуальных услуг // Форсайт. Т. 4. № 1. С. 64-73.

Дорошенко М.Е., Суслов А.Б. (2008) Сектор интеллектуальных услуг: перспективы развития и сценарный анализ // Форсайт. № 2(6). C. $18-35$.

Макаров В.Л., Клейнер Г.Б. (2007) Микроэкономика знаний. М.: Экономика.

Полтерович В.М. (2009) Проблема формирования национальной инновационной системы // Экономика и математические методы. Т. 45. № 2 (апрель-июнь). С. 3-18.

Хорос В. (2000) Постиндустриализм - испытание на прочность // Глобальное сообщество: новая система координат (подходы к проблеме). СПб.: Алетейя, с. 170.

Antonelli C. (1998) Localized technological change, new information technology and the knowledge-based economy: the European evidence // Journal of Evolutionary Economics. Vol. 8. P. 177-198.

Arrow K.J. (1962) The Economic Implications of Learning by Doing // Review of Economic Studies. Vol. 80. P. 155-173.

Audretsch D.B., Klomp L., Thurik R.A. (1999) Do Services Differ from Manufacturing? The Post-Entry Performance of Firms in Dutch Services

// Audretsch D.B., Thurik R.A. (eds.) Innovation, Industry Evolution and Employment. Cambridge: Cambridge University Press. P. $230-252$.

Balaz V. (2004) Knowledge-Intensive Business Services in Transition Economies // The Service Industries Journal. Vol. 24. № 4. P. 83-100.

Bansal H.S., Taylor S.F. (1999) The Service Provider Switching Model (SPSM): A Model of Consumer Switching Behavior in the Services Industry // Journal of Service Research. Vol. 2. №. 2. P. 200-218.

Barras R. (1986) Towards a Theory of Innovations in Services // Research Policy. Vol. 15. № 4. P. 161-173.

Bettencourt L.A., Ostrom A.L., Brown S.W., Roundtree R.T. (2002) Client Co-production in Knowledge-Intensive Business Services // California Management Review. Vol. 44. № 4. P. 100-128.

Bilderbeek R., den Hertog P. (1996) Innovation in Knowledge Intensive Business Services. Lessons from Case Studies. Paper for the Roskilde Seminar on Innovation in Business Services. Roskilde University.

Biyalogorsky E., Gerstner E., Weiss D., Xie J. (2005) The Economics of Service Upgrades // Journal of Service Research. Vol. 7. № 3. P. $234-244$.

Bresnahan T.F. (2002) Prospects for an Information-Technology-Led Productivity Surge. NBER Chapters // Innovation Policy and the Economy. Vol. 2. P. $135-162$.

Clark C. (1940) Conditions of Economic Progress. London: Macmillan.

Cohen W., Levinthal D. (1990) Absorptive Capacity: A New Perspective on Learning and Innovation // Administrative Science Quarterly. Vol. 35. P. 128-152.

Evangelista R., Savona M. (1998) Patterns of Innovation in Services: The Results of Italian Innovation Survey. Paper presented at the 7th Annual RESER Conference, Berlin, 8-10 October.

Fisher A.G.B. (1939) Production, Primary, Secondary and Tertiary // Economic Record. № 15 (June). P. 24-38.

Gallouj C. (1997) Asymmetry of Information and the Service Relationship: Selection and Evaluation of the Service Provider // International Journal of Service Industry Management. Vol. 8. № 1. P. 42-64.

Gassmann O., Kausch C., Enkel E. (2007) Customer Integration in the Early Phase of the Innovation Process. http://www.alexandria.unisg.ch/ publications $/ 17080$

Gibbons M., Limoges C., Nowotny H., Schwartzman S., Scott P., Trow M. (1994) New Production of Knowledge: Dynamics of Science and Research in Contemporary Societies. London: Sage. 
Haukness J. (2000) Dynamic Innovation Systems: What is the Role of Services? // Boden M., Miles I. (eds.) Services and the Knowledgebased Economy. London: Continuum.

den Hertog P. (2000) Knowledge Intensive Business Services as Co-producers of Innovation // International Journal of Innovation Management. Vol. 4. № 4. P. 491-528.

den Hertog P. (2002) Co-producers of Innovation: On the Role of Knowledge-Intensive Business Services in Innovation // Gadrey J., Gallouj F. Productivity, Innovation and Knowledge in Services - New Economic and Socio-economic Approaches. Cheltenham: Edward Elgar.

Hipp C. (1999) Knowledge-Intensive Business Services in the New Mode of Knowledge Production // AI\&Society. Vol. 13. № 1-2. P. 88-106.

Hipp C. (2000) Information Flows and Knowledge Creation in Knowledge-Intensive Business Services: Scheme for a Conceptualization // Metcalfe J.S., Miles I. (eds.) Innovation Systems in the Services Economy: Measurement and Case Study Analysis. Boston: Kluwer Academic Publishers. P. 149-168.

Hipp C., Grupp H. (2005) Innovation in the Service Sector: The Demand for Service-Specific Innovation Measurement Concepts and Typologies // Research Policy. Vol. 34. № 4. P. 517-535.

KIT (2009) Knowledge Intensive Services Procurement Strategy. Results of Empirical Research in Current Practice and Implications for Organization. Karlsruhe: Karlsruhe Institute of Technology. http://www.ksri.kit.edu/Upload/Publications/70765f4b-10cc-4ce4-b87404c3016ad158.pdf

Koch A., Stahlecker T. (2006) Regional Innovation Systems and Foundation of Knowledge Intensive Business Services // European Planning Studies. Vol. 14. № 2. P. 123-146.

Koch A., Strotmann H. (2006) Impact of Functional Integration and Spatial Proximity on the Post-Entry Performance of Knowledge Intensive Business Service Firms // International Small Business Journal. Vol. 24. № 6. P. 610-634.

Kuusisto A., Kuusisto J. (2007) Use of Knowledge Intensive Business Services by SMEs - Some Policy Implications. SC-Research. Lappeenranta University of Technology.

Landry R., Amara N., Doloreux D. (2010) Knowledge-exchange strategies between KIBS firms and their clients // The Service Industries Journal 2010. iFirst Article. P. 1-30.

Levitt T. (1972) Production Line Approach to Service // Harvard Business Review. September-October. P. 41-52.

Marík V., Camarinha-Matos L.M., Afsarmanesh H. (2002) Knowledge and Technology Integration in Production and Services: Balancing Knowledge and Technology in Product and Service Life Cycle. IFIP TC5/WG5.3. Paper presented at the Fifth IFIP/IEEE International Conference on Information Technology for Balanced Automation Systems in Manufacturing and Services (BASYS'02), September 25-27, 2002. Cancun, Mexico.

Miles I. (2007). Business Services and their Users: A Literature Review // Kox H., Rubalcaba L. (eds.) Business Services in European Economic Growth. London: Palgrave Macmillan. P. 39-61.

Miles I. (2008) Patterns of Innovation in Service Industries // IBM Systems Journal. Vol. 47. № 1. P. 115-128.

Miles I., Kastrinos N., Bilderbeek R., den Hertog P., Flanagan K., Huntink W. (1995) Knowledge-Intensive Business Services: Their Role as Users, Carriers and Sources of Innovation. Report to the EC DG XIII Sprint EIMS Programme. Luxembourg.

Miles I., Kastrinos N., Flanagan K., Bilderbeek R., den Hertog P. (1995) Knowledge-Intensive Business Services. Users, Carriers and Sources of Innovation. Manchester: PREST.

Muller E., Zenker A. (2001) Business Services as Actors of Knowledge Transformation: The Role of KIBS in Regional and National Innovation Systems // Research Policy. Vol. 30. № 9. P. 1501-1516.

Muller E., Doloreux D. (2007) The Key Dimensions of Knowledge-Intensive Business Services (KIBS) Analysis: A Decade of Evolution. Fraunhofer ISI Working Papers. Firms and Region. № U1/2007.

Roth S., Woratschek H., Pastowski S. (2006) Negotiating Prices for Customized Services // Journal of Service Research. Vol. 8. № 4. P. $316-$ 329.

Sector Futures (2005). The Knowledge-Intensive Business Services Sector. European Foundation for the Improvement of Living and Working Conditions. http://www.europa.eu.int/comm/employment_social/news/2004sep/eie2004_en/html

Simmie J., Strambach S. (2006) The Contribution of KIBS to Innovation in Cities: An Evolutionary and Institutional Perspective // Journal of Knowledge Management. Vol. 10. № 5. P. 26-40.

Strambach S. (1994) Knowledge-Intensive Business Services in the Rhine-Neckar Area // Tijdschrift voor Economische en Sociale Geografie. Vol. 85. № 4 (November). P. 354-365.

Sundbo J., Gallouj F. (2000) Innovation as a Loosely Couples System in Services // Metcalfe S., Miles I. (eds.) Innovation Systems in the Service Economy. Dordrecht: Kluwer.

Tether B.S. (2003) The Sources and Aims of Innovation in Services: Variety between and within Sectors // Economics of Innovation and New Technology. Vol. 12. № 6. P. 481-505.

Tether B.S., Hipp C. (2000) Competition and Innovation amongst Knowledge Intensive and Other Service Firms: Evidence from Germany // Andersen B., Howells J., Hull R., Miles I., Roberts J. (eds.) Knowledge and Innovation in the New Service Economy. Cheltenham: Edward Elgar.

Tether B.S., Hipp C., Miles I. (2001) Standardisation and Particularization in Services: Evidence from Germany // Research Policy. Vol. 30. P. $1115-1138$.

van der Haar J., Kemp R., Omta O. (2001) Creating Value that Cannot be Copied // Industrial Marketing Management. Vol. 30. № 8. P. 627-636.

Vargo S.L., Lusch R.F. (2004) The Four Service Marketing Myths: Remnants of a Goods-Based, Manufacturing Model // Journal of Service Research. Vol. 6. № 4. P. 324-335.

Walsh K., Enz C.A., Canina L. (2008) The Impact of Strategic Orientation on Intellectual Capital Investments in Customer Service Firms // Journal of Service Research. № 10. P. 300-317. 


\title{
Innovative Potential of the Knowledge-Intensive Services Sector in Russia
}

\author{
Marina Doroshenko \\ Head, Department for Analytical Research, Institute for Statistical Studies and Economics of Knowledge, National Research \\ University — Higher School of Economics, 20 Myasnitskaya str., Moscow, 101000, Russian Federation. E-mail: mdoroshenko@hse.ru
}

\begin{abstract}
$\mathrm{K}$ nowledge-intensive services (KIS) are featured by a high innovation performance thus being one of the key segments of the knowledge economy. This area is targeted by numerous studies primarily aimed at its qualitative characteristics.

Basing on data obtained from an annual monitoring survey of the KIS sector, performed by the HSE ISSEK since 2006, the author reveals the innovative capacity of the KIS and assesses the prospects for its further development.

The study shows that the evolution of the KIS sector is dominated by the two vectors, aimed respectively at standardizing and customizing services. The latter is especially gaining momentum. In this respect, distinction is a key competitive advantage for a service provider. Alongside with evolving innovation and diversified production, this trend will only increase. It is noteworthy that the recent

financial and economic crisis has significantly spurred the service firms' innovation activity.

A distinctive feature of the KIS sector is the ability to shape consumers' aptitude to innovation by the means of "smart" services. Accounting for a growing demand for product, organizational, governance and marketing innovations aimed at dealing with the specific customer, the agenda towards customization will be also accepted by other sectors. This makes a significant contribution to evolving economics of knowledge.

Such a context requires changing manufacturers' patterns of thought. In this sense KIS serve as an effective tool to foster innovative behavior. In parallel with the widening customers' propensity to innovate the range of services and demand for them are also growing thus motivating manufacturers to develop more advanced services. This process thus is self-reinforcing.
\end{abstract}

\section{Keywords}

knowledge-intensive business services, innovation activity, innovation performance, service innovation, standard services, service industrialization, customization, co-production of services

\section{References}

Antonelli C. (1998) Localized technological change, new information technology and the knowledge-based economy: the European evidence. Journal of Evolutionary Economics, vol. 8, pp. 177-198.

Arrow K.J. (1962) The Economic Implications of Learning by Doing. Review of Economic Studies, vol. 80, pp. 155-173.

Audretsch D.B., Klomp L., Thurik R.A. (1999) Do Services Differ from Manufacturing? The Post-Entry Performance of Firms in Dutch Services Innovation, Industry Evolution and Employment, Cambridge: Cambridge University Press, pp. 230-252.

Balaz V. (2004) Knowledge-Intensive Business Services in Transition Economies. The Service Industries Journal, vol. 24, no 4, pp. 83-100.

Bansal H.S., Taylor S.F. (1999) The Service Provider Switching Model (SPSM): A Model of Consumer Switching Behavior in the Services Industry. Journal of Service Research, vol. 2, no 2, pp. 200-218.

Barras R. (1986) Towards a Theory of Innovations in Services. Research Policy, vol. 15, no 4, pp. 161-173.

Bettencourt L.A., Ostrom A.L., Brown S.W., Roundtree R.T. (2002) Client Co-production in Knowledge-Intensive Business Services.

California Management Review, vol. 44, no 4, pp. 100-128.

Bilderbeek R., den Hertog P. (1996) Innovation in Knowledge Intensive Business Services. Lessons from Case Studies. Paper presented at the Roskilde Seminar on Innovation in Business Services, Roskilde University.

Biyalogorsky E., Gerstner E., Weiss D., Xie J. (2005) The Economics of Service Upgrades. Journal of Service Research, vol. 7, no 3, pp. $234-244$. Bresnahan T.F. (2002) Prospects for an Information-Technology-Led Productivity Surge. NBER Chapters. Innovation Policy and the Economy, vol. 2, pp. 135-162.

Clark C. (1940) Conditions of Economic Progress, London: Macmillan.

Cohen W., Levinthal D. (1990) Absorptive Capacity: A New Perspective on Learning and Innovation. Administrative Science Quarterly, vol. 35, pp. $128-152$.

den Hertog P. (2000) Knowledge Intensive Business Services as Co-producers of Innovation. International Journal of Innovation Management, vol. 4, no 4, pp. 491-528. 
den Hertog P. (2002) Co-producers of Innovation: On the Role of Knowledge-Intensive Business Services in Innovation. Productivity, Innovation and Knowledge in Services - New Economic and Socio-economic Approaches (eds. J. Gadrey, F. Gallouj), Cheltenham: Edward Elgar.

Doroshenko M.E. (2007) Intellektual'nye uslugi segodnya i zavtra [Knowledge-Based Services: Today and Tomorrow]. Foresight-Russia, vol. 1, no 2, pp. 37-45.

Doroshenko M.E. (2010) Krizisnye strategii v sektore intellektual'nykh uslug [Crisis Strategies in the Sector of Knowledge-Intensive Services]. Foresight-Russia, vol. 4, no 1, pp. 64-73.

Doroshenko M.E., Suslov A.B. (2008) Sektor intellektual'nykh uslug: perspektivy razvitiya i stsenarnyi analiz [The Sector of Intellectual Services: Prospects of Development and Scenario Analysis]. Foresight-Russia, vol. 2, no 2, pp. 18-35.

European Commission (2005) Sector Futures. The Knowledge-Intensive Business Services Sector, European Foundation for the Improvement of Living and Working Conditions. Available at: http://www.europa.eu.int/comm/employment_social/news/2004sep/eie2004_en/html (accessed 30 November 2011).

Evangelista R., Savona M. (1998) Patterns of Innovation in Services: The Results of Italian Innovation Survey. Paper presented at the 7th Annual RESER Conference, Berlin, 8-10 October, 1998.

Fisher A.G.B. (1939) Production, Primary, Secondary and Tertiary. Economic Record, no 15, p. 24-38.

Gallouj C. (1997) Asymmetry of Information and the Service Relationship: Selection and Evaluation of the Service Provider. International Journal of Service Industry Management, vol. 8, no 1, p. 42-64.

Gassmann O., Kausch C., Enkel E. (2007) Customer Integration in the Early Phase of the Innovation Process. Available at: http://www.alexandria. unisg.ch/publications/17080 (accessed 30 November 2011).

Gibbons M., Limoges C., Nowotny H., Schwartzman S., Scott pp., Trow M. (1994) New Production of Knowledge: Dynamics of Science and Research in Contemporary Societies, London: Sage.

Haukness J. (2000) Dynamic Innovation Systems: What is the Role of Services? Services and the Knowledge-based Economy (eds. M. Boden, I. Miles), London: Continuum.

Hipp C. (1999) Knowledge-Intensive Business Services in the New Mode of Knowledge Production. AI\&Society, vol. 13, no 1-2, pp. 88-106.

Hipp C. (2000) Information Flows and Knowledge Creation in Knowledge-Intensive Business Services: Scheme for a Conceptualization. Innovation Systems in the Services Economy: Measurement and Case Study Analysis (eds. J.S. Metcalfe, I. Miles), Boston: Kluwer Academic Publishers. pp. 149-168.

Hipp C., Grupp H. (2005) Innovation in the Service Sector: The Demand for Service-Specific Innovation Measurement Concepts and Typologies. Research Policy, vol. 34, no 4, pp. 517-535.

Khoros V. (2000) Postindustrializm - ispytanie na prochnost' [Post-Industrialism - A Reliability Proofing]. Global'noe soobshchestvo: novaya sistema koordinat (podkhody k probleme) [Global Community: A New Reference Frame (Approaches to the Problem)], Saint-Petersburg: Aleteiya.

KIT (2009) Knowledge Intensive Services Procurement Strategy. Results of Empirical Research in Current Practice and Implications for Organization, Karlsruhe: Karlsruhe Institute of Technology. Available at: http://www.ksri.kit.edu/Upload/Publications/70765f4b-10cc-4ce4b874-04c3016ad158.pdf (accessed 30 November 2011).

Koch A., Stahlecker T. (2006) Regional Innovation Systems and Foundation of Knowledge Intensive Business Services. European Planning Studies, vol. 14, no 2, pp. 123-146.

Koch A., Strotmann H. (2006) Impact of Functional Integration and Spatial Proximity on the Post-Entry Performance of Knowledge Intensive Business Service Firms. International Small Business Journal, vol. 24, no 6, pp. 610-634.

Kuusisto A., Kuusisto J. (2007) Use of Knowledge Intensive Business Services by SMEs - Some Policy Implications. SC-Research, Lappeenranta: Lappeenranta University of Technology.

Landry R., Amara N., Doloreux D. (2010) Knowledge-exchange strategies between KIBS firms and their clients. The Service Industries Journal 2010, iFirst Article, pp. 1-30.

Levitt T. (1972) Production Line Approach to Service. Harvard Business Review, September-October, pp. 41-52.

Makarov V.L., Kleiner G.B. (2007) Mikroekonomika znanii [Micro-Economics of Knowledge], Moscow: Ekonomika.

Marík V., Camarinha-Matos L.M., Afsarmanesh H. (2002) Knowledge and Technology Integration in Production and Services: Balancing Knowledge and Technology in Product and Service Life Cycle. IFIP TC5/WG5.3. Paper presented at the Fifth IFIP/IEEE International Conference on Information Technology for Balanced Automation Systems in Manufacturing and Services (BASYS'02), September 25-27, 2002, Cancun, Mexico.

Miles I. (2007) Business Services and their Users: A Literature Review. Business Services in European Economic Growth (eds. H. Kox, L. Rubalcaba), London: Palgrave Macmillan, pp. 39-61.

Miles I. (2008) Patterns of Innovation in Service Industries. IBM Systems Journal, vol. 47, no 1, pp. 115-128.

Miles I., Kastrinos N., Bilderbeek R., den Hertog P., Flanagan K., Huntink W. (1995) Knowledge-Intensive Business Services: Their Role as Users, Carriers and Sources of Innovation (Report to the EC DG XIII Sprint EIMS Programme), Luxembourg.

Miles I., Kastrinos N., Flanagan K., Bilderbeek R., den Hertog P. (1995) Knowledge-Intensive Business Services. Users, Carriers and Sources of Innovation, Manchester: PREST.

Muller E., Doloreux D. (2007) The Key Dimensions of Knowledge-Intensive Business Services (KIBS) Analysis: A Decade of Evolution. Fraunhofer ISI Working Papers. Firms and Region, no U1/2007.

Muller E., Zenker A. (2001) Business Services as Actors of Knowledge Transformation: The Role of KIBS in Regional and National Innovation Systems. Research Policy, vol. 30, no 9, pp. 1501-1516.

Polterovich V.M. (2009) Problema formirovaniya natsional'noi innovatsionnoi sistemy [Problem of Shaping National Innovation System]. Ekonomika i matematicheskie metody, vol. 45, no 2, pp. 3-18.

Roth S., Woratschek H., Pastowski S. (2006) Negotiating Prices for Customized Services. Journal of Service Research, vol. 8, no 4, pp. $316-329$.

Simmie J., Strambach S. (2006) The Contribution of KIBS to Innovation in Cities: An Evolutionary and Institutional Perspective. Journal of Knowledge Management, vol. 10, no 5, pp. 26-40.

Strambach S. (1994) Knowledge-Intensive Business Services in the Rhine-Neckar Area. Tijdschrift voor Economische en Sociale Geografie, vol. 85 , no 4 , pp. 354-365.

Sundbo J., Gallouj F. (2000) Innovation as a Loosely Couples System in Services. Innovation Systems in the Service Economy (eds. S. Metcalfe, I. Miles), Dordrecht: Kluwer.

Tether B.S. (2003) The Sources and Aims of Innovation in Services: Variety between and within Sectors. Economics of Innovation and New Technology, vol. 12, no 6, pp. 481-505.

Tether B.S., Hipp C. (2000) Competition and Innovation amongst Knowledge Intensive and Other Service Firms: Evidence from Germany. Knowledge and Innovation in the New Service Economy (eds. B. Andersen, J. Howells, R. Hull, I. Miles, J. Roberts), Cheltenham: Edward Elgar

Tether B.S., Hipp C., Miles I. (2001) Standardisation and Particularization in Services: Evidence from Germany. Research Policy, vol. 30, pp. 1115-1138.

van der Haar J., Kemp R., Omta O. (2001) Creating Value that Cannot be Copied. Industrial Marketing Management, vol. 30 , no 8, pp. 627-636.

Vargo S.L., Lusch R.F. (2004) The Four Service Marketing Myths: Remnants of a Goods-Based, Manufacturing Model. Journal of Service Research, vol. 6, no 4, pp. 324-335.

Walsh K., Enz C.A., Canina L. (2008) The Impact of Strategic Orientation on Intellectual Capital Investments in Customer Service Firms. Journal of Service Research, no 10, pp. 300-317. 


\section{Интернационализация венчурного капитала}

\section{Вызовы и возможности}

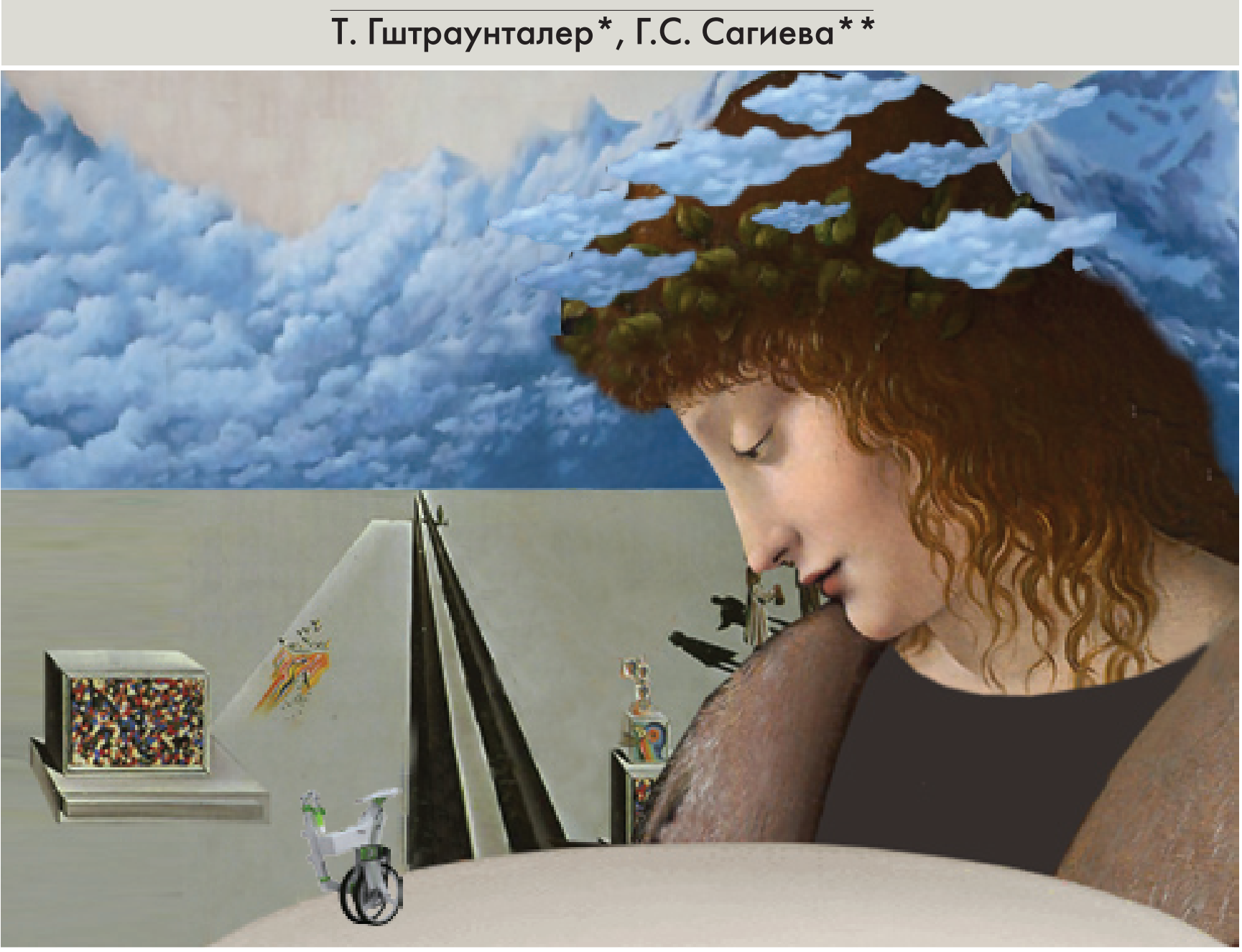

Среди существующих инструментов поддержки инновационного бизнеса венчурный капитал для многих начинающих компаний оказывается единственным, но вместе с тем труднодоступным ресурсом. Являясь своеобразным фильтром, он открывает дорогу проектам лишь самой высокой «пробы». Работая в условиях повышенного финансового риска, венчурные инвесторы руководствуются логикой, ориентированной на ожидаемую рынком новизну.

Авторы раскрывают сущность этой логики и практикуемые в венчурной сфере бизнес-модели и стратегии. В статье оценивается вклад венчурной индустрии в экономический рост, анализируются проблемные зоны и факторы, стимулирующие ее развитие'.

* Гштраунталер Томас - ведущий научный сотрудник, Лаборатория экономики инноваций, ИСИЭЗ НИУ ВШЭ. Адрес: Национальный исследовательский университет «Высшая школа экономики», 101000, Москва, Мясницкая ул., 20. E-mail: tgstraunthaler@hse.ru

** Сагиева Галина Сибгатулловна - заведующая отделом исследований интеллектуальной собственности и трансферта технологий ИСИЭЗ НИУ ВШЭ.

Адрес: Национальный исследовательский университет «Высшая школа экономики», 101000, Москва, Мясницкая ул., 20. E-mail: sagieva@hse.ru 


\section{Актуальность венчурной индустрии}

На начальном этапе развития компании испытывают многочисленные трудности, прежде всего дефицит финансовых средств. Использование заемного капитала (если его вообще удается привлечь) впоследствии лишь ведет к увеличению затрат за счет выплат процентов по кредитам. Многие эксперты считают ограниченный доступ к капиталу одним из самых серьезных препятствий, с которым сталкиваются перспективные предприниматели [Evans, Jovanovich, 1989; и др.]. Этот фактор сдерживает появление и развитие новых предприятий, особенно в высокотехнологичных секторах, что в итоге может негативно повлиять на всю экономику. Указанная проблема особенно остро проявляется в развивающихся странах [Berger, Udell, 1998]. Ее широкое обсуждение в экономической литературе свидетельствует о значимости функционирующих рынков капитала как движущей силы экономического развития (см., в частности, [Schumpeter, 1911; Rajan, Zingales, 1998]).

Почему же перспективным стартапам так трудно привлечь инвестиции? В качестве одной из ключевых проблем отметим недостаточную информированность возможных инвесторов о проекте [Greenwald et al., 1984]. Размещение акций стартапов - типичный случай проявления известного феномена, называемого "проблемой “лимона"» (lemon problem) $[\text { Akerlof, 1970] }]^{2}$. Компании, испытывающие острую потребность в финансировании, лишь начинают свою деятельность, их перспективы неясны, а потенциал развития не очевиден для внешних наблюдателей. Финансовые институты, проявляющие особенную осторожность, такие как банки, не практикуют венчурное инвестирование, несмотря на привлекательную перспективную отдачу, так как не располагают компетенциями в оценке потенциала бизнеса на быстро развивающихся рынках. Далеко не все проекты исследований и разработок (ИиР) завершаются достижением значительных результатов, а итоги интеллектуальной деятельности не всегда приводят к получению ожидаемых эффектов. К тому же, продуктами научно-технической деятельности могут воспользоваться многочисленные конкуренты.

Наконец, существует вероятность, что менеджмент компании-бенефициара неэффективно потратит выделенные средства, обеспечив скорее личное обогащение, чем жизнедеятельность компании. K примеру, мотивация начинающей биотехнологической компании к выполнению заявленной программы исследований может значительно снизиться уже с момента получения первого транша инвестиций.

В силу указанных причин финансирование подобных проектов априори сопровождается высокими рисками. Их предупреждение и минимизация негативных последствий требуют от инвестора значительных затрат, активного участия в управлении собственными вложениями и поддержки тесных личных связей. Он должен обеспечивать вложенным средствам более жесткий контроль, чем, к примеру, держатель облигаций. Многие инвесторы не готовы проявить столь активную вовлеченность, другие попросту не могут этого сделать из-за отсутствия необходимых компетенций либо наличия законодательных ограничений [Jensen, 1993].

Венчурные капиталисты специализируются именно на участии в подобных рисковых инициативах. Обладая необходимыми знаниями и опытом в оценке инвестиционных возможностей, они выступают в роли финансовых посредников в привлечении других инвесторов, располагают необходимыми временными и финансовыми ресурсами для проведения тщательного аудита, по итогам которого и принимают окончательное решение.

Венчурный капитал - одна из немногих концепций, которая характеризуется столь противоречивыми оценками. С одной стороны, рисковые инвесторы воспринимаются как провидцы, предвосхищающие появление будущих инноваций, с другой - как «креатуры обратной стороны капитализма», стремящиеся заработать капитал на новаторских идеях ученых и изобретателей. Что же все-таки представляет собой венчурный капитал на самом деле?

Индустрия венчурного капитала включает широкий спектр видов финансовой деятельности, от инвестирования на ранней стадии проекта (при отсутствии собственных оборотных средств у предприятия) до привлечения частного акционерного капитала на последующих этапах. Венчурные инвестиции вливаются в акционерный капитал (equity financing) в обмен на долю в уставном капитале или акции компании либо предоставляются в форме инвестиционного кредита (debt financing), как правило, на срок от 2 до 7 лет. В отличие от стратегических инвесторов или партнеров провайдеры венчурного акционерного капитала не стремятся приобрести контрольный пакет акций, который остается у руководства компании, особенно на раннем этапе проекта.

Венчурный капитал остается важным источником поддержки новых предприятий и, следовательно, ключевым драйвером экономического роста, особенно для предпринимательского сектора в США [Neck et al., 2003]. Радикальное отличие подобных инвесторов от других рыночных игроков заключается в наборе предоставляемых ими услуг, что обусловливает повышенный интерес к ним. Они не просто «вливают капитал», а оказывают руководящую и наставническую поддержку подопечным компаниям [Barry, 1994]. В случае успеха венчурный инвестор получает вознаграждение, в несколько раз превышающее сумму вложенных средств. Интерес венчурных капиталистов лежит, прежде всего, в плоскости быстрорастущих, многообещающих, но 
вместе с тем, высоко рисковых секторов, таких как биотехнологии, ИКТ, производство программного обеспечения и т. п.

Обычно венчурные инвесторы вступают в игру после прохождения проектом «посевной» стадии финансирования (seed funding), а именно - на этапе роста (раунд серии А). Они нацелены на извлечение прибыли после первичного публичного размещения акций компании (initial public offering, IPO) или ее продажи.

Венчурные капиталисты рискуют избирательно, но по-крупному. Они активно участвуют в создании добавочной стоимости, в управлении инвестициями и зачастую вносят весомый вклад в их успех [Jeng, Wells, 2000]. Для этого они привлекают посредников, например специалистов по патентному праву, способствуют необходимому притоку высококвалифицированных работников, включаются в корпоративное управление инвестируемыми компаниями, таким образом снижая риски для других внешних контрагентов.

Поскольку основные активы стартапов носят скорее нематериальный характер, классические формы корпоративного управления для них мало применимы. Например, IPO, подготовленные фондами венчурного капитала со сложившейся рыночной репутацией, приносят гораздо более высокие прибыли в сравнении с другими источниками.

Венчурные средства предоставляются в основном через независимые фонды. В них аккумулируется капитал различных традиционных финансовых институтов - как национальных, так и зарубежных (финансово-промышленных групп, банков, страховых компаний и пенсионных фондов), - а также сбережения населения и средства государства, выделяемые различными министерствами и ведомствами на программы поддержки предпринимательства, в том числе в высокотехнологичных отраслях. При этом венчурные фонды, специализирующиеся на работе со стартапами, используют преимущественно государственные средства, в то время как фонды, сотрудничающие с более зрелыми компаниями, финансируют их в основном из средств частных и корпоративных источников.

\section{Венчурная индустрия: история и современность}

Современная венчурная индустрия зародилась в Соединенных Штатах, которые и по сей день остаются местом ее наибольшей концентрации. На долю США приходится более 3/4 объема мирового венчурного капитала. Пионером венчурного инвестирования стала Американская корпорация исследований и разработок (American Research and Development Corporation), основанная после Второй мировой войны [Bygrave, Timmons, 1999]. Первой компанией, сумевшей привлечь рисковый капитал, принято считать Fairchild Semiconductors, созданную в 1957 г. для производства кремниевых транзисторов. В настоящее время в Кремниевой долине функционируют свыше 600 венчурных компаний и фондов. Такие компьютерные гиганты, как
Apple, Compaq, Sun Microsystems, Microsoft, Lotus, Intel, своим развитием во многом обязаны именно венчурному капиталу. Благодаря ему стало возможным стремительное развитие новых секторов, в том числе производства персональных компьютеров и биотехнологий.

Несмотря на наличие громких «историй успеха», до начала 1980-х гг. венчурная индустрия оставалась сравнительно маломасштабной. Совокупного оборота в 1 млрд долл. ей удалось достичь лишь в 1982 г. Стремительный рост начался в 1990-х гг., пик развития продолжался вплоть до краха «доткомов» в 1998-2000 гг. Причем если в 1999 г. общий объем капиталовложений в национальные компании США составил 56 млрд долл., то в 2000 г. около 5000 портфельных компаний получили инвестиции на сумму 100 млрд долл. [Neck et al., 2003].

В ряде европейских стран рост рискового предпринимательства зафиксирован в начале 1980-х гг. Во многом он объяснялся повышением интере са менеджеров к приобретению управляемых ими компаний. Вплоть до начала 1990-х гг. инвестирование в акции частных фирм в европейских странах, за исключением Великобритании и Нидерландов, оставалось на довольно низком уровне. Треть всего объема венчурных средств предоставлялась банками, ориентированными на относительно безопасные вложения. В Европе отсутствовал ликвидный транснациональный фондовый рынок для малых фирм, аналогичный NASDAQ в США. Однако во второй половине 1990-х гг. с развитием рынков ценных бумаг венчурное финансирование и здесь испытало резкий подъем. Так, в 1997 г. по сравнению с предыдущим годом венчурные инвестиции в Германии выросли более чем в 6.5 раз, а в Швеции почти в 20 раз.

Предпочтение отдавалось в основном компаниям, находящимся на ранней стадии развития: с 1993 по 1997 г. вложенный в них капитал в общеевропейском масштабе увеличился более чем втрое. Сумма венчурных инвестиций в период с 1996 по 2000 г. превысила 91 млрд евро, из них в высокотехнологичный сектор поступило свыше 25 млрд евро. Капиталовложения в малые высокотехнологичные фирмы составили 25\% от общего объема. Если в 1997 г. 6000 компаний получили 9.7 млрд евро венчурных инвестиций, то уже в 2001 г. их сумма в странах ЕС увеличилась до 24.5 млрд евро. В настоящее время в странах ЕС насчитывается более 500 венчурных фондов и компаний, 320 из которых являются членами Европейской ассоциации венчурного капитала (European Venture Capital Association), основанной в 1973 г. В последние годы во многих странах Европы - Германии, Финляндии и др., - а также в Израиле зафиксирован значительный рост венчурной индустрии.

С начала 2000-х гг. венчурный капитал стал поступать в развивающиеся страны Юго-Восточной Азии, в первую очередь в Китай, Республику Корея и Сингапур. Этот процесс был обусловлен поиском венчурными фондами новых возможностей инвестирования растущих объемов накопленного 
капитала после краха «доткомов» в странах их происхождения.

Распространение венчурного инвестирования отмечено и в европейских странах с переходной экономикой. Подобные наблюдения свидетельству ют о растущей интернационализации венчурного капитала, его свободной и стремительной миграции в поисках оптимальных инвестиционных возможностей. Выявлено, что около 50\% средств в европейские и азиатские фонды венчурного капитала поступают из зарубежных источников [Gompers, 2005].

Одним из основных очагов концентрации мирового рискового капитала остается Китай. До 1998 г. приток венчурных средств в страну был весьма ограниченным, что побудило правительство ввести ряд стимулирующих мер. В результате объемы финансирования начали стремительно увеличиваться, и уже в 2001 г. в Китае и Гонконге сосредоточилось почти $30 \%$ частных инвестиций, поступавших в Азию. К середине 2002 г. объем венчурных средств, привлеченных в континентальный Китай, составил 1.57 млрд долл., а в 2003 г. такая же сумма была инвестирована в частный акционерный капитал за рубежом.

Международные венчурные институты играют крайне важную роль в наращивании знаний и социального капитала стартапов в регионах, не охваченных мощными источниками финансирования [Maula, Mäkelä, 2003]. Кроме того, присутствие иностранных венчурных капиталистов, как правило, стимулирует активность местных инвесторов, что можно видеть на примере Китая. Прогрессу венчурной индустрии на локальном уровне, особенно в развивающихся странах, препятствует множество факторов, в частности отсутствие необходимого опыта [Ray, 1991]. Принимая во внимание бурный рост стартапов и другие сопутствующие эффекты для местных инвесторов, вызванные привлечением международного венчурного капитала, не удивительно, что данная сфера продолжает укрепляться и в России.

Российская индустрия венчурного капитала значительно менее масштабна, чем в Китае, хотя зародилась раньше. Средний процент от инвестиций на сумму 600 млн долл., вложенных в 300 проектов в период с 1994 по 2001 г., составил 16\%. В начале 1990-х гг. благодаря дополнительным венчурным средствам, поступившим от международных институтов, таких как Международный валютный фонд и Европейский банк реконструкции и развития, были образованы 10 региональных фондов с общим объемом капитала 320 млн долл. [TACIS, 2001]. На сегодняшний день о своем присутствии в России заявили более 40 венчурных фондов с суммарными активами не менее 4.3 млрд долл. На территории страны размещены представительства 30 компаний, управляющих венчурными фондами [Алипов, Самохин, 2009]. Примечательно, что $27 \%$ венчурного капитала было вложено в продовольственный сектор РФ, 9\% - в медицину и фармакологию, 5\% - в производство упаковки и лишь $25 \%$ - в классические высокотехнологичные стартапы [Batjargal, 2007]. Значительные объемы средств инвестируют корпоративные венчурные фонды «Лукойла», «Роснефти» и др. Довольно активную деятельность ведет ОАО «Российская венчурная компания» (РBK), созданная в 2006 г. для управления государственными венчурными фондами и имеющая статус института развития. РВК инвестирует средства в венчурные фонды, учреждаемые совместно с частными инвесторами. Число фондов, сформированных РВК, достигло двенадцати, из них два находятся под зарубежной юрисдикцией. Совокупный капитал фондов составляет 25.5 млрд руб., доля РВК - более 15 млрд руб. К сентябрю 2011 г. РВК проинвестировала 76 инновационных компаний на сумму 8.3 млрд руб. [Российская венчурная компания, 2011].

\section{Механизм принятия решений о венчурном инвестировании}

Принятию решений и оценке прибыльности в венчурном инвестировании посвящено большое число исследований. Однако многим из этих, преимущественно эмпирических, работ присущи методологические недостатки, в частности - ретроспективная отчетность и использование анкетных вопросов вместо реальной оценки. Тем не менее, их анализ показывает, что при принятии решений венчурные капиталисты во всем мире руководствуются примерно одними и теми же факторами [Knight, 1994; Rah et al., 1994]. Несмотря на то, что этот процесс часто описывают как непрозрачный и почти таинственный, литература по стратегическому менеджменту демонстрирует, что он протекает по схожим схемам [Shepherd, 1999]. Венчурные капиталисты проверяют соответствие ключевых компетенций предприятия базовым факторам успеха в соответствующем секторе. Проведенные ранее эмпирические исследования свидетельствуют, что анализ выживаемости новых предприятий и потенциальной производительности - одно из основных направлений анализа в стратегическом менеджменте [maм же]. В их фокусе - рынки, характер конкурентных взаимодействий и состав руководства. Для наращивания своих конкурентных преимуществ в виде специальных знаний многие венчуристы фокусируются только на одном секторе, например, биотехнологиях. Кроме того, венчурные игроки оценивают, как менеджмент планирует позиционировать свою компанию на рынке. Поскольку большинство новых высокотехнологичных рынков нестабильны, венчуристы «тестируют» способность менеджмента адаптироваться к изменениям внешней среды.

Так как венчурные капиталисты ориентированы на сверхприбыли, им необходима уверенность в том, что инвестируемая компания останется во главе конкурентной гонки достаточно длительное время. Этот фактор приобретает критическое значение при отсутствии развитой системы патентования. Таким образом, предметом первоочередного интереса инвесторов становятся входные барьеры, продлевающие срок действия «преимущества первопроходца» - до тех пор, пока оно не будет 
устранено догоняющими компаниями. Долгий период лидирования необходим не только для капитализации ранее вложенных инвестиций в ИиР, но и для совершенствования новыми компаниями своей продукции и услуг. Кроме того, это позволяет менеджменту приобрести опыт, поставить новые задачи, перераспределить функции, создать неформальные структуры, установить стабильные связи со стейкхолдерами и т. п. Однако, если предприятие ориентировано на еще не существующие рынки, одного наличия перспективного продукта или услуги, масштабируемой бизнес-модели и длительного времени лидирования может оказаться недостаточно. В подобных случаях (например, в секторе ИКТ или биотехнологий) компания должна продемонстрировать освоение компетенций и ресурсов, которые позволят привлечь внимание рынка, другими словами, обладать «способностью к обучению» (educational capability).

Один из важнейших вопросов, на который рисковые игроки ищут ответ, если не самый важный, действительно ли руководство инвестируемой компании готово к успешному воплощению намеченного бизнес-плана [Dixon, 1991]. Для этого они руководствуются такими критериями, как степень компетентности соискателя финансирования в соответствующем секторе, личные обязательства перед создающейся компанией, предыдущий опыт работы со стартапами. Исследования, посвященные оценке роли специальных знаний [Cooper, 1986; Bruderl et al., 1992], показывают, что опыт деятельности в определенном секторе является чрезвычайно значимым атрибутом для успешного начала проекта [Roure, Maidique, 1986]. В условиях интенсивно растущих высокотехнологичных рынков нет времени на обучение, поскольку возможности возникают там очень быстро, и наличие опытной команды менеджеров становится жизненно необходимым [Feeser, Willard, 1990].

\section{Региональная специфика рынков венчурного капитала}

Несмотря на то, что венчурные капиталисты, принимая решение об инвестировании, чаще всего руководствуются одними и теми же критериями, траектории развития венчурной индустрии в отдельных государствах существенно различаются, что осложняет проведение межстрановых сопоставлений. Так, сравнительный анализ по Германии, Израилю, Японии и Великобритании [Mayer et al., 2005] продемонстрировал существенные отличия в динамике развития венчурной сферы, инвестиционных стратегиях, схемах и источниках финансирования. Они иллюстрируются разбросами значений таких показателей, как объем средств и инвестиционная политика пенсионных фондов на рынках Европы, США и Азии [Megginson, 2004].

Например, развитая индустрия венчурного капитала в США ориентирована на новые технологии (доля инновационных высокотехнологичных компаний в общем числе проинвестированных предприятий составляет $60 \%$ ) и охватывает различные типы инвесторов, включая пенсионные фонды, страховые компании и частных лиц. Европейская венчурная индустрия значительно моложе, ее основные игроки - банки, а фокус - на ключевых секторах рынка. В Западной Европе венчурный капитал выделяется в основном на цели развития. Отметим, что в 1990-х гг. по мере увеличения объемов финансирования венчурные инвестиции в этом регионе стали смещаться в зону низких рисков и, соответственно, меньшей прибыльности. Японские венчурные игроки являются, как правило, дочерними подразделениями финансовых институтов, которые осуществляют прямые инвестиции в надежные компании, преимущественно в форме кредитов. В развивающихся экономиках, к которым относится и Россия, основными источниками капитала являются средства банковского и государственного секторов.

Географическое распределение венчурного капитала внутри стран также варьируется. Это можно увидеть на примере Германии и Великобритании [Martin et al., 2002]. В Китае венчурная активность отмечается во всех 53 высокотехнологичных зонах. В России венчурные инвестиции сконцентрированы преимущественно в Москве; зарубежный капитал направляется также в промышленно развитые северо-западные регионы страны. В работах [Kenney et al., 2002a, b, c] показаны существенные различия между странами Азии. Все большее число исследований посвящается специфике государств Центральной и Восточной Европы [Wright, Kissane, Burrows, 2004].

Как наилучшим образом систематизировать и охарактеризовать эти различия? До недавнего времени изучались, главным образом, факторы, связанные со спросом и предложением венчурного капитала. Большой массив статей посвящен выявлению условий, благоприятствующих росту активности венчурного капитала на микро- и макроуровнях или сдерживающих его. В них описано множество факторов [La Porta et al., 1997; и др.], однако не вполне очевидно, оказывают ли они влияние непосредственно на венчурный капитал либо на предпринимательскую деятельность в целом, что имеет опосредованные эффекты и для привлечения венчурного капитала [Acs, Audretsch, 1994]. Растущая экономика может предложить больше возможностей для технологических лидеров и таким образом создать привлекательные инвестиционные условия. В свою очередь, благодаря повышению рыночной капитализации расширяется доступ компаний к капиталу, который может быть направлен на стимулирование их деятельности.

Основное внимание исследователей рынков капитала было направлено на изучение роли IPO [Black, Gilson, 1998; и др.]. IPО - наиболее перспективная стратегия выхода из венчурного проекта, обеспечивающая инвесторам высокую прибыльность. Этот механизм предусматривает финансовые стимулы и для менеджеров, владеющих акциями компании, обеспечивая их колл-опционом для контроля над фирмой, поскольку венчурные капиталисты 
на стадии IPO прекращают контроль [Black, Gilson, 1998]. Высказываются и иные мнения, критикующие сфокусированность исследователей на рынке капитала. IPO имеют весьма сильную корреляцию с активностью венчурного капитала лишь на поздних стадиях венчурных инвестиций. Многие страны, например Сингапур, Тайвань или Израиль, сумели привлечь колоссальные объемы таких средств, не обладая развитыми рынками капитала ${ }^{3}$ Тем не менее, в ряде государств, в частности в России, отсутствие подобного рынка приводит к тому, что венчурные инвестиционные компании ведут бизнес, не имея четкой стратегии выхода.

Другие авторы пытаются предсказывать инвестиционные решения, принимаемые венчурными капиталистами, оценивая их способность просчитывать риски и потенциальную выгоду. Однако возможные объемы прибыли существенно варьиру ются в зависимости от рынка [Manigart et al., 2002]. Инвесторы ранних стадий идут на больший риск и, соответственно, требуют большей компенсации, чем те, кто вступает в игру позднее, например, специалисты по выкупу акций. Они предпочитают вкладывать в компании, обладающие собственными оборотными средствами и надежной кредитной историей. При изучении стран с переходной экономикой не удалось установить четкой зависимости объемов извлекаемой прибыли от стадии инвестирования, служащей критерием приемлемости риска [Karsai et al., 1999]. Интересный вывод, однако не слишком неожиданный. Вследствие быстрого роста рынков вознаграждение за успешные капиталовложения может оказаться несоизмеримо выше, чем в развитых странах. Это оправдывает капиталовложения в условиях высокого риска. Для лучшего понимания стремлений венчурных фондов вкладывать в высокорисковые компании, а не в «надежные», необходимо иметь представление о степени их склонности к риску и существующем портфеле. Для венчурных фондов глобального мас штаба, в основном инвестирующих в более зрелые компании, имеет смысл направлять часть капитала в быстрорастущие переходные экономики с многочисленными высокорисковыми, но и в потенциале высокоокупаемыми стартапами. Таким образом, географическое расположение инвестируемых компаний и степень их «рискованности» - малоинформативные показатели: возможно, венчуристы всего лишь стремятся к международной диверсификации рисков. Подобный тезис подтверждается выводами, сделанными в работе [Hall, Tu, 2003], где показано, что готовность венчурных компаний инвестировать в заокеанские рынки зависит от размера последних.

Немало исследований посвящено изучению правового ландшафта отдельных стран. Руководствуясь преимущественно описательными методами, большинство авторов склонны излишне акцентировать внимание на законодательстве развитых государств и недооценивать проблемы с правоприменительной практикой в развивающихся странах. Конечно, жесткие законы о банкротстве могут привести к существенному удорожанию дефолта, но обычно венчурный капиталист делает ставку не на высокий процент возврата, а, скорее, на внутреннюю диверсификацию рисков. Другими словами, он самостоятельно распределяет риски дефолта. Так, чтобы гарантировать покрытие своих убытков, венчуристы пользуются разнообразными механизмами финансирования и контрактными условиями. Может меняться и их собственная инвестиционная стратегия. Некоторые из них предпочитают долгосрочные вложения, другие - краткосрочные. Независимые венчуристы чаще всего не заинтересованы в долгосрочном инвестировании, тогда как корпоративные стремятся получить доступ к ключевым технологиям.

C другой стороны, имеет место недооценка правовой среды. В Китае, например, несмотря на заметный прогресс в развитии венчурной индустрии, существуют серьезные институциональные и регулятивные проблемы, которые скорее отпугивают иностранных инвесторов, а не привлекают их. Наиболее распространенная юридическая форма инвестируемых компаний - партнерство с ограниченной ответственностью - китайским законодательством не признается. Если фирма регистрируется с таким статусом, различий между ее активами и находящимся в управлении капиталом не делается, что значительно усиливает правовую неопределенность для инвестора. Возможности выхода из подобной ситуации для финансируемых компаний в стране ограничены, а квалифицированные финансовые менеджеры в дефиците. Как итог - условия для развития венчурной индустрии далеко не оптимальные.

Сказанное выше во многом характерно и для России. В правовую практику РФ понятие «венчурный фонд» было введено еще в 2002 г. (постановление Федеральной комиссии по ценным бумагам от 14.08.2002 г. № 31). Однако венчурные (особо рисковые) фонды были отнесены к категории закрытых паевых инвестиционных фондов, что в корне неверно, так как подобный статус не учитывает важнейшие специфические характеристики данного вида инвестирования. Юридический статус компаний с участием венчурного капитала вообще не регламентирован российским законодательством.

В условиях неразвитых механизмов реализации прав собственности, характерных для многих стран с развивающейся экономикой, при анализе венчурного капитала на первый план выходит фактор трансакционных издержек. В этом случае особую роль играют доступ к социальным сетям и общественный авторитет компании [McKnight et al., 1998, Gill et al., 2005]. В работе [Batjargal, 2007] проведена оценка значимости неформальных сетей в Китае и, что примечательно, в России. Автор приходит к выводу, что связи поручителя с венчурным капиталистом, с одной стороны, и с предпринимателем, с другой, а также личное доверие между поручителем

Подробнее о развитии рынков в этих странах см.: [Kenney et al., 2002a, b, c] 
и венчурным капиталистом оказывают позитивный эффект на принятие инвестиционных решений. Китайские социальные сети - «гуаньси» [Xin, Pearce, 1996] - содействуют повышению межличностного доверия [Farh et al., 1998], мобильности работников [Bian, 1997] и производительности компании [Park, Luo, 2001; Batjargal, 2003b, 2007]. Российские социальные сети - «связи» [Yakubovich, 2005] или «блат» [Ledeneva, 1998] - имеют примерно те же эффекты, в частности, способствуют увеличению производительности предприятия [Batjargal, 2001, 2003a], позволяют россиянам найти достойное место работы [Yakubovich, 2005], обеспечивают предпринимателям доступ к ресурсам [Sedaitis, 1998]. Таким образом, развитые социальные связи снижают неопределенность при заключении финансовых сделок [Guseva, Rona-Tas, 2001], оказывая сильное влияние на принятие инвестиционных решений венчурными капиталистами.

Гораздо меньшее число работ посвящено изучению подходов менеджмента инвестируемых компаний к оценке внешней среды и решению проблем, зависящих от специфики экономических институтов, с которыми они связаны. В подобных публикациях демонстрируются примеры значительного влияния культуры на развитие венчурного капитала в определенных регионах. Перечень исследований, посвященных культурным различиям, огромен, однако из-за определенных трудностей, связанных с проведением подобного анализа, культурные и социальные факторы часто оказываются неучтенными [Wright et al., 2003]. Показано, что в странах Азии благодаря социальным ценностям, основанным на коллективизме, агентские проблемы не особо актуальны [Hofstede, Bond, 1988]. В дополнение, имеет место и другой фактор, иллюстрирующий роль социокультурной составляющей, а именно уровень доверия между представителями различных стран. Многочисленные публикации отмечают положительное влияние доверия на экономический рост [Zak, Knack, 2001; и др.]. В работе [Bottazzi et al., 2010] проанализировано действие данного эффекта на индустрию венчурного капитала, выражающееся в росте инвестирования. Доказано, что это доверие не ограничивается рамками одного государства: если иностранный партнер - резидент страны, обладающей надежной репутацией, следовательно, сам объект инвестиций вызывает аналогичное доверие.

\section{Перспективы развития исследований венчурной сферы}

Несмотря на интересные и содержательные открытия в изучении сферы венчурного капитала, исследования в данной области характеризуются определенными пробелами. В частности, излишнее значение придается роли фондовых рынков и другим институциональным факторам, что объяснимо с точки зрения методологических преимуществ подобных подходов. Однако в этом случае другим важным факторам уделяется недостаточное внимание. В частности, требует осторожности оценка влияния институциональной среды на деятельность венчурных инвесторов, которых могут посчитать всего лишь «жертвами обстоятельств», что не соответствует действительности. Такой подход провоцирует шаблонные политические меры. Например, политики могут рассматривать многогранный мир венчурного капитала в отдельной стране только с позиции его наличия либо отсутствия. Еще один существенный недостаток - чрезмерный фокус на определенных секторах, таких как обрабатывающая промышленность. Для более полного понимания динамики современных рынков венчурного капитала необходимо сместить акцент на трансграничную деятельность сервисных компаний.

Таким образом, настало время новых, более рафинированных подходов к изучению венчурного капитала. Одна из ключевых задач - выявить внутренние стимулы развития рассматриваемой сферы. Это поможет политикам увидеть, в каком состоянии находится венчурная индустрия в той или иной стране, как она развивается и какую роль может сыграть государство в ее поддержке и росте. Станет возможным многосторонний анализ отдельных сегментов рынка венчурного капитала. Так, более зрелая компания по-прежнему зависит от качества функционирования рынка IPO, в то время как для стартапов данный фактор не играет существенной роли. Аналогичные различия были выявлены и в отношении неэластичности рынков труда, оказывающей значительное влияние на компании, находящиеся на ранней стадии развития, и лишь ограниченное - на более зрелые предприятия.

В дальнейшем в изучении венчурного капитала необходимо уделять больше внимания усилению его интернационализации. Это одно из самых интересных и перспективных направлений исследований в ближайшем будущем. В статье [Dixit, Jayaraman, 2001] описаны три модели интернационализации. Во-первых, часть фондов венчурного капитала специализируются на каком-либо одном географическом регионе либо на определенном секторе. Поэтому обладание передовыми узкопрофильными знаниями может стать преимуществом при принятии инвестиционных решений (модель специализированного финансирования). Во-вторых, специальные знания, относящиеся к определенной стране или сектору, могут быть транслированы в другие страны, за пределы «родных» рынков инвестора (модель органичного роста). В-третьих, опыт может передаваться посредством совместного инвестирования при участии местного партнера (аффилиационная модель).

Наконец, факторами, на которые ориентируется венчурный капитал, являются степень предпринимательской активности и качество предлагаемых идей. Венчурные капиталисты, прежде всего, выбирают страны с высоким уровнем предпринимательства, инновационной активности, ожидаемой прибыльности проектов и перспективами роста [Baygan, Freudenberg, 2000]. Государственная политика, например поддержка программ, должна способствовать аккумулированию венчурного капитала. Подобная деятельность, однако, может 
иметь и негативный эффект, например вытеснение частного венчурного капитала государственными фондами. До сих пор ни одному из исследователей не удалось доказать стимулирующий эффект государственного вмешательства в развитие венчурной деятельности. Какую роль в таком случае может играть государство?

Если внешняя среда не будет благоприятствовать венчурному капиталу, многие инвесторы несомненно займут настороженную позицию. Государству с неразвитым законодательством в отношении прав собственности либо угрозой национализации частной собственности не удастся привлечь венчурный капитал и повысить предпринимательскую активность. Но даже в условиях неблагоприятной конъюнктуры венчурные инвесторы имеют достаточно возможностей получения прибыли. К примеру, с целью снизить рыночный риск венчурист может заключить партнерское соглашение с местным агентом, что наблюдается в Китае. Если в целевой стране не развит рынок IPO, венчурный капиталист может организовать его в США, что и произошло в случае Израиля и Сингапура. В то время как многие исследователи пытаются найти решение в поддерживающих государственных инициативах, существует риск, что индикаторы, по-настоящему интересные для венчурных инвесторов, - предпринимательская активность, инновации, компетенции, - не получат должного внимания. Более того, объемы прибыли, извлекаемые венчурными капиталистами в определенном месте, могут стать мощным сигналом для их коллег. Сверхвысокие доходы спровоцируют рост капиталовложений в новые фонды. Ранее проведенные исследования заставляют предположить, что кривые предложения, скорее всего, весьма эластичны.

Наиболее оптимальный вклад государства стимулирование креативного мышления и предпринимательской активности. Для повышения инвестиционной привлекательности необходимо реформировать систему образования, одновременно формируя культуру, поощряющую конкурентное и предпринимательское мышление. Эффекты подобных инициатив проявятся лишь спустя значительное время, тем не менее, их запуск необходим уже сейчас.

Алипов С., Самохин В. (2009) Зарубежный венчурный капитал в России. http://business.rin.ru/cgi-bin/search.pl?action=view\&num=3415 70\&razdel $=40 \& w=0 \& p \_n=1$

Российская венчурная компания (2011) Материалы сайта. Краткая информация. http://www.rusventure.ru/ru/company/brief

Acs Z., Audretsch D.B. (1994) New Firm Start-ups, Technology, and Macroeconomic Fluctuation // Small Business Economics. Vol. 6. № 6. P. 439-449.

Akerlof G.A. (1970) The Market for "Lemons": Quality Uncertainty and the Market Mechanism // The Quarterly Journal of Economics. Vol. 84. № 3. P. 488-500.

Barry C. (1994) New Directions on Research in Venture Capital Finance // Financial Management. Vol. 23. № 3. P. 3-15.

Batjargal B. (2001) Effects of Networks on Entrepreneurial Performance in a Transition Economy: The Case of Russia // Reynolds P., Autio E., Brush C., Bygrave W., Manigart S., Sapienza H., Shaver K. (eds.) Frontiers of Entrepreneurship Research. Babson Park, MA: Babson College Center for Entrepreneurship. P. 97-110.

Batjargal B. (2003a) Social Capital and Entrepreneurial Performance in Russia: A Longitudinal Study // Organizational Studies. Vol. 24 . № 4. P. 535-556.

Batjargal B. (2003b) Internet Entrepreneurship in an Emerging Market: Networks and Performance of Internet Startups. Academy of Management Best Conference Paper 2003 BPS: H6.

Batjargal B. (2007) Network Triads: Transitivity, Referral and Venture Capital Decisions in China and Russia // Journal of International Business Studies. Vol. 38. № 6. P. 998-1012.

Baygan G., Freudenberg M. (2000) The Internationalization of Venture Capital Activity in Countries: Implications for Measurement and Policy STI Working Papers - 2000/7. Paris: OECD.

Berger A.N., Udell G.F. (1998) The Economics of Small Business Finance: The Roles of Private Equity and Debt Markets in the Financial Growth Cycle // Journal of Banking and Finance. Vol. 11. P. 613-673.

Bian Y. (1997) Bringing Strong Ties Back In: Indirect Ties, Network Bridges, and Job Searches in China // American Sociological Review. Vol. 62. № 3. P. 366-385.

Black B., Gilson S. (1998) Venture Capital and the Structure of Capital Markets: Banks versus Stock Markets // Journal of Financial Economics. Vol. 47. P. 243-277.

Bottazzi L., Da Rin M., Hellmann T. (2010) The Importance of Trust for Investment: Evidence from Venture Capital. Working Paper № 325. Milano: IGIER - Università Bocconi.

Bruderl J., Preisendorfer P., Ziegler R. (1992) Survival Chances of Newly Founded Business Organizations // American Sociological Review. Vol. 57. P. 227-242.

Bygrave W., Timmons J. (1999) Venture Capital: Predictions and Outcomes // Wright M., Robbie K. (eds.) Management Buy-outs and Venture Capital: Into the Next Millennium. Cheltenham: Edward Elgar.

Cooper A. (1986) Comparison with the Manufacturing Sector // Scandinavian International Business Review. Vol. 1. № 1. P. 39-56.

Dixit A., Jayaraman N. (2001) Internationalization Strategies of Private Equity Firms // Journal of Private Equity. Winter. P. 40-54.

Dixon R. (1991) VCs and the Appraisal of Investments // OMEGA International Journal of Management Science. Vol. 19. P. 333-344.

Evans D., Jovanovich B. (1989) An Estimated Model of Entrepreneurial Choice under Liquidity Constraints // Journal of Political Economy. Vol. 97. № 4. P. 808-827.

Farh L., Tsui A., Xin K, Cheng B. (1998) The Influence of Relational Demography and Guanxi: The Chinese Case // Organization Science. Vol. 9. № 4. P. 471-488. 
Feeser H.R., Willard G.E. (1990) Founding Strategy and Performance: A Comparison of High and Low Growth High Tech Firms // Strategic Management Journal. Vol. 11. P. 87-98.

Gill H., Boies K., Finegan J., McNally J. (2005) Antecedents of Trust: Establishing a Boundary Condition for the Relation between Propensity to Trust and Intention to Trust // Journal of Business and Psychology. Vol. 19. № 3. P. 287-302.

Gompers P. (2005) Venture Capital // Eckbo B.E. (ed.) Handbook of Corporate Finance. Elsevier/North Holland.

Greenwald B., Stiglitz J. E., Weiss A. (1984) Informational Imperfections in the Capital Market and Macroeconomic Fluctuations // The American Economic Review. Vol. 74. № 2. P. 194-199.

Guseva A., Rona-Tas A. (2001) Uncertainty, Risk, and Trust: Russian and American Credit Card Markets Compared // American Sociological Review. Vol. 66. № 5. P. 623-646.

Hall G., Tu C. (2003) Venture Capitalists and the Decision to Invest Overseas // Venture Capital. Vol. 5. № 2. P. 181-190.

Hofstede G., Bond M.H. (1988) The Confucius Connection: From Cultural Roots to Economic Growth // Organizational Dynamics. Vol. 16. № 4. P. 4-21.

Jeng L., Wells P. (2000) The Determinants of Venture Capital Funding: Evidence across Countries // Journal of Corporate Finance. Vol. 6. P. 89-241.

Jensen M.C. (1993) Presidential Address: The Modern Industrial Revolution, Exit, and the Failure of Internal Control Systems // Journal of Finance. Vol. 48. P. 831-880.

Karsai J., Wright M., Dudzinski Z., Morovic J. (1999) Venture Capital in Transition Economies - the Cases of Hungary, Poland and Slovakia // Wright M., Robbie K. (eds.) Management Buy-outs and Venture Capital into the Next Millenium. Cheltenham: Edward Elgar.

Kenney M., Han K., Tanaka S. (2002a) The Globalization of Venture Capital: The Cases of Taiwan and Japan (mimeo).

Kenney M., Han K.,Tanaka S. (2002b) Adapting to Strange Environments: Venture Capital in Japan, Korea and Taiwan. Paper presented at the 2002 Annual Meeting of the Academy of International Business, San Juan, Puerto Rico.

Kenney M., Han K., Tanaka S. (2002c) Scattering Geese: The Venture Capital Industries of East Asia. Report to the World Bank. Berkeley Roundtable on the International Economy, WP146. Berkeley, CA.

Knight R. (1994) Criteria Used by Venture Capitalists: A Cross Cultural Analysis // International Small Business Journal. Vol. 13. № 1. P. 26-37.

La Porta R., Lopez-De-Silanes F., Shleifer A., Vishny R. (1997) Legal Determinants of External Finance // Journal of Finance. P. 52. № 3. P. 1131-1150

Ledeneva A. (1998) Russia’s Economy of Favors: Blat, Networking and Informal Exchange. Cambridge: Cambridge University Press.

Manigart S., De Waele K., Wright M., Robbie K., Desbrieres P., Sapienza H., Beekman A. (2002) Determinantts of Required Return in Venture Capital Investments: A Five Country Study // Journal of Business Venturing. Vol. 17. № 4. P. 291-312.

Martin R., Sunley P., Turner D. (2002) Taking Risks in Regions: the Geographical Anatomy of Europe's Emerging Venture Capital Market // Journal of Economic Geography. Vol. 2. № 2. P. 121-150.

Maula M., Mäkelä M. (2003) Cross-border Venture Capital // Hyytinen A., Pajarinen M. (eds.) Financial Systems and Firm Performance: Theoretical and Empirical Perspectives. Helsinki: Taloustieto.

Mayer C., Schoors K., Yafeh Y. (2005) Sources of Funds and Investment Activities of Venture Capital Funds: Evidence from Germany, Israel, Japan and the UK // Journal of Corporate Finance. Vol. 11. P. 586-608.

McKnight D.H., Cummings L.L., Chervany N.L. (1998) Initial Trust Formation in New Organizational Relationships // Academy of Management Review. Vol. 23. № 3. P. 473-490.

Megginson W. (2004) Toward a Global Model of Venture Capital? // Accenture Journal of Applied Corporate Finance. Vol. 16. № 1. P. 7-26.

Neck H., Zacharakis A., Bygrave W., Reynolds P. (2003) Global Entrepreneurship Monitor National Assessment. United States Executive Report 2002. Kansas City, MO: The Kauffman Foundation.

Park S., Luo Y. (2001) Guanxi and Organizational Dynamics: Organizational Networking in Chinese Firms // Strategic Management Journal. Vol. 22. № 5. P. 455-477.

Rah J., Jung K, Lee J. (1994) Validation of the Venture Evaluation Model in Korea // Journal of Business Venturing. Vol. 9. P. 24-509.

Rajan R., Zingales L. (1998) Financial Dependence and Growth // American Economic Review. Vol. 88. P. 559-586.

Ray D. (1991) Venture Capital and Entrepreneurial Developments in Singapore // International Small Business Journal. Vol. 10. № 1. P. 11-26.

Roure J. B., Maidique M. A. (1986) Linking Prefunding Factors and High-technology Venture Success: An Exploratory Study // Journal of Business Venturing. Vol. 1. P. 295-306.

Roure J.B., Keeley R.H. (1990) Predictors of Success in New Technology Based Ventures // Journal of Business Venturing. Vol. 5. № 4. P. 201-220.

Schumpeter J.A. (1911) A Theory of Economic Development. Cambridge, MA: Harvard University Press.

Sedaitis J. (1998) The Alliances of Spin-offs versus Start-ups: Social Ties in the Genesis of Post-Soviet Alliances // Organization Science. Vol. 9. № 3. P. 368-381.

Shepherd D. (1999) Venture Capitalists’ Assessment of New Venture Survival // Management Science. Vol. 45. № 5. P. $621-632$.

TACIS (2001) Venture Capital in Russia. Policy paper. Brussels.

Uzzi B., Gillespie J. (2002) Knowledge Spillover in Corporate Financing Networks: Embeddedness and the Firm's Debt Performance // Strategic Management Journal. Vol. 23. № 7. P. 595-618.

Wright M., Kissane J., Burrows A. (2004) Private Equity and the EU Accession Countries of Central and Eastern Europe // Journal of Private Equity. Vol. 7. № 3. P. 32-46.

Wright M., Sapienza H., Busenitz L. (2003) Introduction. Venture Capital. Vol. I. Cheltenham: Edward Elgar.

Xin K., Pearce J. (1996) Guanxi: Connections as Substitutes for Formal Institutional Support // Academy of Management Journal. Vol. 39. № 6. P. 1641-1658.

Yakubovich V. (2005) Weak Ties, Information and Influence: How Workers Find Jobs in a Local Russian Labor Market // American Sociological Review. Vol. 70. № 3. P. 408-421.

Zak P., Knack S. (2001) Trust and Growth // Economic Journal. Vol. 111. P. 295-321. 


\title{
The Internationalization of Venture Capital: Challenges and Opportunities
}

\author{
Thomas Gstraunthaler \\ Leading Research Fellow, Laboratory for Economics of Innovation, Institute for Statistical Studies and Economics of \\ Knowledge, National Research University - Higher School of Economics, 20 Myasnitskaya str., Moscow, 101000, Russian \\ Federation. E-mail: tgstraunthaler@hse.ru \\ Galina Sagieva \\ Head, Division for Intellectual Property and Technology Transfer Studies, Institute for Statistical Studies and Economics of \\ Knowledge, National Research University - Higher School of Economics, 20 Myasnitskaya Str., Moscow, 101000, Russian \\ Federation. E-mail: sagieva@hse.ru
}

\begin{abstract}
$\mathrm{T}$ he paper attempts to summarize and systematize the landscape of the global venture capital industry. It presents major basic business models and investment strategies, assesses the contribution of venture capital (VC) to economic growth as well as incentives and constraints for VC's development, and identifies research gaps in this area.

Venture capital is often regarded as the only source for supporting start-ups, particularly that ones in high-tech innovative sectors. The authors disclose the prerequisites for this situation. It is emphasized that in contrast to most traditional investors a VC provider must possess sound skills in the target area of investment as well as long-term strategic focus. The financial capital venture capitalists provide however is only one of the benefits they bring to entrepreneurs. Venture capitalists support companies with industry knowledge and social capital which has of ten proved vital for their success. Also, venture capital acts in an intermediate role for companies to attract further financial means. These circumstances made public administrators interested in venture capital, and more and

more nations adapt pro-investment policies to support their ailing economies and to assure future competitiveness. The authors believe that governments can only do so much to spur creative thinking and entrepreneurial activities. The best chance to be attractive for international investors is probably a pro-active stance towards education, combined with the creation of a culture which rewards competitive and entrepreneurial thinking. These processes take a long time to manifest, but they are vital.

In conclusion, the authors point to the need to introduce new and refined research strategies in VC area. One key focus to study venture capital is to understand how the industry itself is developing through its own drive. It would help to see at what stage of development the venture capital industry of a country is in comparison to others. It would allow policy makers to understand where the industry is developing to and how to best support or participate in their growth. It would also allow studying some segments of the venture capital market differently to others. In addition, further analysis of any facets of the VC industry should be conducted through the prism of its internationalization.
\end{abstract}

\section{Keywords}

venture capital, innovative company, innovation startup, capital market, venture investment, venture capitalist, venture fund, regional pattern

\section{References}

Acs Z., Audretsch D.B. (1994) New Firm Start-ups, Technology, and Macroeconomic Fluctuation. Small Business Economic, vol. 6, no 6, pp. 439-449.

Alipov C., Samokhin V. (2009) Zarubezhnyi venchurnyi kapital v Rossii [Foreign Venture Capital in Russia]. Available at: http://business. rin.ru/cgi-bin/search.pl?action=view\&num $=341570 \&$ razdel $=40 \& w=0 \& p \_n=1($ accessed 30 November 2011$)$.

Akerlof G.A. (1970) The Market for "Lemons": Quality Uncertainty and the Market Mechanism. The Quarterly Journal of Economics, vol. 84, no 3, pp. 488-500.

Barry C. (1994) New Directions on Research in Venture Capital Finance. Financial Management, vol. 23, no 3, pp. 3-15.

Batjargal B. (2001) Effects of Networks on Entrepreneurial Performance in a Transition Economy: The Case of Russia. Frontiers of Entrepreneurship Research (eds. P. Reynolds, E. Autio, C. Brush, W. Bygrave, S. Manigart, H Sapienza., K. Shaver), Babson Park, MA: Babson College Center for Entrepreneurship, pp. 97-110.

Batjargal B. (2003a) Social Capital and Entrepreneurial Performance in Russia: A Longitudinal Study. Organizational Studies, vol. 24 no 4,pp. 535-556.

Batjargal B. (2003b) Internet Entrepreneurship in an Emerging Market: Networks and Performance of Internet Startups. Paper presented at Academy of Management Best Conference, 2003 BPS: H6.

Batjargal B. (2007) Network Triads: Transitivity, Referral and Venture Capital Decisions in China and Russia. Journal of International Business Studies, vol. 38, no 6, pp. 998-1012.

Baygan G., Freudenberg M. (2000) The Internationalization of Venture Capital Activity in Countries: Implications for Measurement and Policy. STI Working Papers, 2000/7, Paris: OECD.

Berger A.N., Udell G.F. (1998) The Economics of Small Business Finance: The Roles of Private Equity and Debt Markets in the Financial Growth Cycle. Journal of Banking and Finance, vol. 11, pp. 613-673. 
Bian Y. (1997) Bringing Strong Ties Back In: Indirect Ties, Network Bridges and Job Searches in China. American Sociological Review, vol. 62, no 3, pp. 366-385.

Black B., Gilson S. (1998) Venture Capital and the Structure of Capital Markets: Banks versus Stock Markets. Journal of Financial Economics, vol. 47, pp. 243-277.

Bottazzi L., Da Rin M., Hellmann T. (2010) The Importance of Trust for Investment: Evidence from Venture Capital (Working Paper no 325), Milano: IGIER - Università Bocconi.

Bruderl J., Preisendorfer P., Ziegler R. (1992) Survival Chances of Newly Founded Business Organizations. American Sociological Review, vol. 57, pp. 227-242.

Bygrave W., Timmons J. (1999) Venture Capital: Predictions and Outcomes. Management Buy-outs and Venture Capital: Into the Next Millennium (eds. M. Wright, K. Robbie), Cheltenham: Edward Elgar.

Cooper A. (1986) Comparison with the Manufacturing Sector. Scandinavian International Business Review, vol. 1, no 1, pp. $39-56$.

Dixit A., Jayaraman N. (2001) Internationalization Strategies of Private Equity Firms. Journal of Private Equity, Winter, pp. 40-54.

Dixon R. (1991) VCs and the Appraisal of Investments. OMEGA International Journal of Management Science, vol.19, pp. $333-344$.

Evans D., Jovanovich B. (1989) An Estimated Model of Entrepreneurial Choice under Liquidity Constraints. Journal of Political Economy, vol. 97 , no 4 , pp. $808-827$.

Farh L., Tsui A., Xin K, Cheng B. (1998) The Influence of Relational Demography and Guanxi: The Chinese Case. Organization Science, vol. 9 , no 4 , pp. 471-488.

Feeser H.R., Willard G.E. (1990) Founding Strategy and Performance: A Comparison of High and Low Growth High Tech Firms. Strategic Management Journal, vol. 11, pp. 87-98.

Gill H., Boies K., Finegan J., McNally J. (2005) Antecedents of Trust: Establishing a Boundary Condition for the Relation between Propensity to Trust and Intention to Trust. Journal of Business and Psychology, vol. 19, no 3, pp. 287-302.

Gompers P. (2005) Venture Capital. Handbook of Corporate Finance (ed. B.E. Eckbo), Elsevier.

Greenwald B., Stiglitz J. E., Weiss A. (1984) Informational Imperfections in the Capital Market and Macroeconomic Fluctuations. The American Economic Review, vol. 74, no 2, pp. 194-199.

Guseva A., Rona-Tas A. (2001) Uncertainty, Risk, and Trust: Russian and American Credit Card Markets Compared. American Sociological Review, vol. 66, no 5, pp. 623-646.

Hall G., Tu C. (2003) Venture Capitalists and the Decision to Invest Overseas. Venture Capital, vol. 5, no 2, pp. 181-190.

Hofstede G., Bond M.H. (1988) The Confucius Connection: From Cultural Roots to Economic Growth. Organizational Dynamics, vol.16, no 4, pp. 4-21.

Jeng L., Wells P. (2000) The Determinants of Venture Capital Funding: Evidence across Countries. Journal of Corporate Finance, vol. 6 , pp. 89-241.

Jensen M.C. (1993) Presidential Address: The Modern Industrial Revolution, Exit, and the Failure of Internal Control Systems. Journal of Finance, vol. 48 , pp. $831-880$

Karsai J., Wright M., Dudzinski Z., Morovic J. (1999) Venture Capital in Transition Economies - the Cases of Hungary, Poland and Slovakia. Management Buy-outs and Venture Capital into the Next Millenium (eds. Wright M., Robbie K.), Cheltenham: Edward Elgar.

Kenney M., Han K., Tanaka S. (2002a) The Globalization of Venture Capital: The Cases of Taiwan and Japan (mimeo).

Kenney M., Han K.,Tanaka S. (2002b) Adapting to Strange Environments: Venture Capital in Japan, Korea and Taiwan. Paper presented at the 2002 Annual Meeting of the Academy of International Business, San Juan, Puerto Rico.

Kenney M., Han K., Tanaka S. (2002c) Scattering Geese: The Venture Capital Industries of East Asia (Report to the World Bank WP146). Berkeley Roundtable on the International Economy, Berkeley, CA.

Knight R. (1994) Criteria Used by Venture Capitalists: A Cross Cultural Analysis. International Small Business Journal, vol. 13, no 1, pp. 26-37.

La Porta R., Lopez-De-Silanes F., Shleifer A., Vishny R. (1997) Legal Determinants of External Finance. Journal of Finance, vol. 52, no 3, pp. 1131-1150.

Ledeneva A. (1998) Russia's Economy of Favors: Blat, Networking and Informal Exchange, Cambridge: Cambridge University Press.

Manigart S., De Waele K., Wright M., Robbie K., Desbrieres P., Sapienza H., Beekman A. (2002) Determinantts of Required Return in Venture Capital Investments: A Five Country Study. Journal of Business Venturing, vol. 17, no 4, pp. 291-312.

Martin R., Sunley P., Turner D. (2002) Taking Risks in Regions: the Geographical Anatomy of Europe’s Emerging Venture Capital Market. Journal of Economic Geography, vol. 2, no 2, pp. 121-150.

Maula M., Mäkelä M. (2003) Cross-border Venture Capital. Financial Systems and Firm Performance: Theoretical and Empirical Perspectives (eds. A. Hyytinen, M. Pajarinen), Helsinki: Taloustieto, pp. 269-291.

Mayer C., Schoors K., Yafeh Y. (2005) Sources of Funds and Investment Activities of Venture Capital Funds: Evidence from Germany, Israel, Japan and the UK. Journal of Corporate Finance, vol. 11, pp. 586-608.

McKnight D.H., Cummings L.L., Chervany N.L. (1998) Initial Trust Formation in New Organizational Relationships. Academy of Management Review, vol. 23, no 3, pp. 473-490.

Megginson W. (2004) Toward a Global Model of Venture Capital? Accenture Journal of Applied Corporate Finance, vol.16, no 1, pp. 7-26.

Neck H., Zacharakis A., Bygrave W., Reynolds P. (2003) Global Entrepreneurship Monitor National Assessment (United States Executive Report 2002), Kansas City, MO: The Kauffman Foundation.

Park S., Luo Y. (2001) Guanxi and Organizational Dynamics: Organizational Networking in Chinese Firms. Strategic Management Journal, vol. 22, no 5, pp. 455-477.

Rah J., Jung K, Lee J. (1994) Validation of the Venture Evaluation Model in Korea. Journal of Business Venturing, vol. 9, pp. $24-509$.

Rajan R., Zingales L. (1998) Financial Dependence and Growth. American Economic Review, vol. 88, pp. 559-586.

Ray D. (1991) Venture Capital and Entrepreneurial Developments in Singapore. International Small Business Journal, vol. 10, no 1, pp. 11-26.

Roure J. B., Maidique M. A. (1986) Linking Prefunding Factors and High-technology Venture Success: An Exploratory Study. Journal of Business Venturing, vol. 1, pp. 295-306.

Roure J.B., Keeley R.H. (1990) Predictors of Success in New Technology Based Ventures. Journal of Business Venturing, vol. 5, no 4, pp. $201-220$.

Schumpeter J.A. (1911) A Theory of Economic Development, Cambridge, MA: Harvard University Press.

Sedaitis J. (1998) The Alliances of Spin-offs versus Start-ups: Social Ties in the Genesis of Post-Soviet Alliances. Organization Science, vol. 9, no 3, pp. $368-381$.

Shepherd D. (1999) Venture Capitalists' Assessment of New Venture Survival. Management Science, vol. 45, no 5, pp. 621-632.

TACIS (2001) Venture Capital in Russia (Policy paper), Brussels.

Uzzi B., Gillespie J. (2002) Knowledge Spillover in Corporate Financing Networks: Embeddedness and the Firm's Debt Performance. Strategic Management Journal, vol. 23, no 7, pp. 595-618.

Wright M., Kissane J., Burrows A. (2004) Private Equity and the EU Accession Countries of Central and Eastern Europe. Journal of Private Equity, vol. 7, no 3, pp. 32-46.

Wright M., Sapienza H., Busenitz L. (2003) Introduction. Venture Capital. Vol. I, Cheltenham: Edward Elgar.

Xin K., Pearce J. (1996) Guanxi: Connections as Substitutes for Formal Institutional Support. Academy of Management Journal, vol. 39, no 6, pp. 1641-1658.

Yakubovich V. (2005) Weak Ties, Information and Influence: How Workers Find Jobs in a Local Russian Labor Market. American Sociological Review, vol. 70, no 3, pp. 408-421.

Zak P., Knack S. (2001) Trust and Growth. Economic Journal, vol. 111, pp. 295-321. 


\section{Эффективный Форсайт Симбиоз экспертизы и фактов}

Тема долгосрочного прогнозирования науки и технологий как основного ресурса инновационного развития становится все более актуальной.

Уже в течение пяти лет журнал «Форсайт» стремится объективно отображать происходящие в этой сфере явления и процессы. Нашим изданием были посеяны своего рода «семена» новых знаний.

О том, какие «плоды» они принесли за истекший период, а также о «нанобудущем» России и остального мира своим мнением делится председатель Научно-технического совета при совете директоров ОАО «РОСНАНО», директор Центра фотохимии РАН академик Михаил Владимирович Алфимов.

Михаил Владимирович, как Вы оцениваете результативность «посева» новых сложных знаний журналом «Форсайт»?

Журнал для меня, несоменно, интересен, несмотря на то, что ориентирован в основном не на ученыхестественников, а на тех, кто исследует сферу науки и инноваций, формирует политику. На мой взгляд, издание заполняет нишу, которая в России долгое время пустовала. Кроме всего прочего, оно ценно тем, что формирует культуру Форсайта и способствует развитию междисциплинарного мышления у читателей. Я бы отметил высокое качество статей, профессионализм авторов, среди которых много ведущих зарубежных исследователей. Журнал выполняет полезную работу, и я желаю ему успехов.

Какие принципиально новые открытия, способные оказать долгосрочное влияние на экономику и общество, появились за те пять лет, что издается «Форсайт» ?

В сфере своих научных интересов я бы выделил два наиболее ярких результата, которые определят дальнейшее развитие материаловедения. Одно из них открытие графена, за которое его авторы, выходцы из России, получили в 2010 г. Нобелевскую премию. Материал представляет собой монослой углерода с уникальными свойствами, в первую очередь, электрическими. Графен открывает новое направление в создании проводящих пленок толщиной в один атом. На его основе могут конструироваться интегральные схемы, светодиоды и т.д. Реализуются ли эти разработки на практике или нет - покажет жизнь.

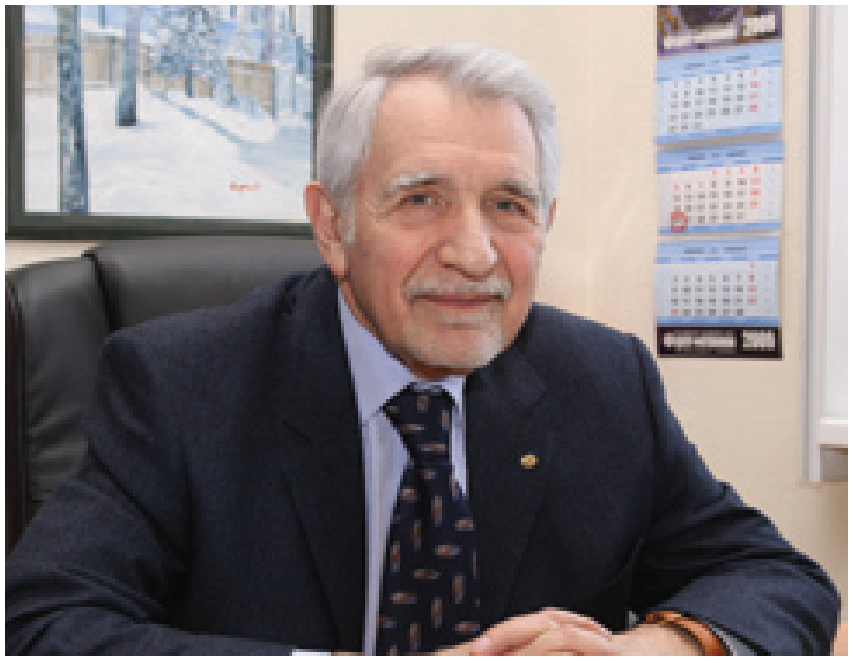

Второе открытие сделано около десяти лет назад, его можно причислить как к научным, поскольку оно стало результатом исследований, так и к технологическим. Ученые нашли способ производства органических полимерных материалов с уникальными свойствами, на основе которых можно создавать принципиально новые устройства. Если раньше электронные приборы базировались на кремнии, то сегодня созданы материалы, позволяющие изготавливать их из полимера - так называемые материалы печатной электроники. Они обладают гибкостью, большой поверхностью, не дороги и легки в изготовлении, что говорит об их значительном потенциале.

Традиционная электроника производится в условиях высокого вакуума и связана с напылением на подложку определенных веществ. Новая же технология позволяет выпускать электронные устройства путем нанесения жидких слоев, по принципу действия напоминая полиграфию. Как и в производстве печатной продукции, в ней также используются «краски», только из полимерных материалов. На ее основе будут созданы гибкие электропроводящие, светоизлучающие материалы и т. д. Если вернуться к графену, то его тоже научились производить по такой технологии.

За этими открытиями последовали разработки, позволяющие выпускать посредством печатной технологии различные устройства: источники света, солнечные батареи, электронику и пр. Они станут на порядки дешевле, а по форме будут выглядеть как гибкие листы, либо излучающие свет, либо под действием солнечного света вырабатывающие электрическую энергию. Например, светильники в виде панели легко 
прикрепляются на стену или любой другой предмет. Батарея, представляющая собой тонкую прозрачную пленку, приклеенную к окну, днем будет накапливать энергию, а ночью служить источником света.

Это прорывное решение на первом этапе будет лишь дополнять традиционные технологии - проводниковые и полупроводниковые, - но постепенно изменит облик окружающей нас действительности. На выставках уже демонстрируются прозрачные источники света в виде листа, из которого можно вырезать любую форму.

В России по этим направлениям также ведутся разработки. Лидирующих позиций мы не занимаем, но до тех пор пока не начнется массовый выпуск, у нас есть шанс не отстать.

Наш институт не исключение. В частности, на основе печатных технологий сотрудниками института разрабатываются устройства, определяющие концентрацию вредных веществ в помещении. Они представляют собой маленькие датчики в виде пленок и предназначены для нефтеперерабатывающей промышленности и других секторов, где существует необходимость непрерывного контроля вредных веществ.

Другая область применения пленочных устройствиндивидуальная медицинская диагностика (контроль выдоха человека или летучих веществ, проникающих через кожу). Тонкие полоски пленки приклеиваются на кожу и фиксируют летучие вещества (кислород, углекислый газ, аммиак и т.д.), выделяемые в процессе жизнедеятельности человека. Например, прибор определяет концентрацию ацетона в выдохе, и таким образом диагностируется диабет.

Насколько ожидаемыми были эти открытия? Можно ли было их предвидеть?

Эти открытия не только ожидались, но, более того, ряд ученых целенаправленно вели эксперименты в данных направлениях.

Естественно, ни одно открытие не может быть спрогнозировано со стопроцентной точностью. Тем не менее, ученые его моделируют, вначале виртуально формируя необходимые параметры, а затем проводят эксперименты, чтобы получить материалы с новыми свойствами.

Когда начнется промышленное тиражирование названных Вами разработок?

Опытное производство уже ведется. Так, ряд западных компаний начали выпускать солнечные батареи. Наши голландские партнеры намечают массовый выпуск с начала 2013 г.

В какой степени специалисты Вашей сферы руководствуются результатами долгосрочных прогнозов в выборе приоритетов своих исследований?

Наш институт регулярно проводит подобный анализ. На его основе готовится дорожная карта. В ней задаются приоритетные научные направления и возможные сферы их приложения, соответственно которым мы реализуем наши проекты. Дорожную карту разработки флуоресцентных хемосенсорных материалов мы создали три года назад. Дорожная карта регулярно корректируется, таким образом, наше видение будущих сегментов рынка постоянно обновляется.

\section{Насколько актуальны для нашего общества долго- срочные научно-технологические и социально- экономические прогнозы?}

По причине разной ориентированности Форсайта и дорожных карт долгосрочный прогноз должен строиться на основе как того, так и другого. Дело в том, что дорожные карты нацелены, прежде всего, на планирование производства конкретных продуктов. В свою очередь, Форсайт направлен на выявление прорывных технологий. В его основе лежит экспертная оценка, что имеет свои достоинства и недостатки. Основной минус - дефицит высококвалифицированных экспертов, наблюдаемый как в России, так и за рубежом, что напрямую влияет на качество прогнозов. Сегодня предпринимаются попытки устранить этот пробел путем комбинирования двух подходов: в дополнение к экспертным методам разрабатываются технологии обработки неструктурированной информации. Последние основаны на поиске и анализе необходимых сведений по семантическому принципу, который опирается не на ключевые слова и библиометрические показатели, а на смыслы информации. Средний цикл «эволюции» информации от идеи до продукта составляет 5-7 лет. Мировая база данных ежегодно прирастает на 5-7 млн публикаций. Другими словами, вся информация, необходимая для сознания нового продукта, уже существует, остается только ее найти.

Выявив технологии, можно оценить потенциал их реализации в России. Это зависит от наличия соответствующих заделов, необходимых специалистов и т. д. В условиях ограниченности ресурсов страна должна делать выбор в пользу продуктовых или технологических направлений. С моей точки зрения, у нас отдается предпочтение продуктовому направлению, что неверно. Поскольку мы как «догоняющая» сторона не можем вести разработки в широком спектре областей одновременно, для нас критически важен правильный выбор технологий. Причем технологии должны быть универсальные, что позволит, оставаясь в рамках одной технологии, создавать разнообразные продукты - солнечные батареи, химические сенсоры, технологии доставки лекарств и т. п.

Для России очень важно выбирать технологические сегменты с высоким потенциалом, в которые целесообразно направлять значительные инвестиции. Это позволит в будущем конкурировать на мировом рынке.

\section{Что Вы думаете о будущем отечественной науки?}

Государство, на мой взгляд, делает много, однако объем финансирования недостаточен. Частный сектор практически не участвует в финансировании не только науки, но и технологических разработок. А к чему мы придем, предвидеть трудно - это зависит от слишком многих факторов. 


\section{МЕЖДУНАРОДНЫЙ НАУЧНЫЙ СЕМИНАР \\ ФОРСАЙТ И НАУЧНО-ТЕХНИЧЕСКАЯ И ИННОВАЦИОННАЯ ПОЛИТИКА}

\section{Лучший опыт}

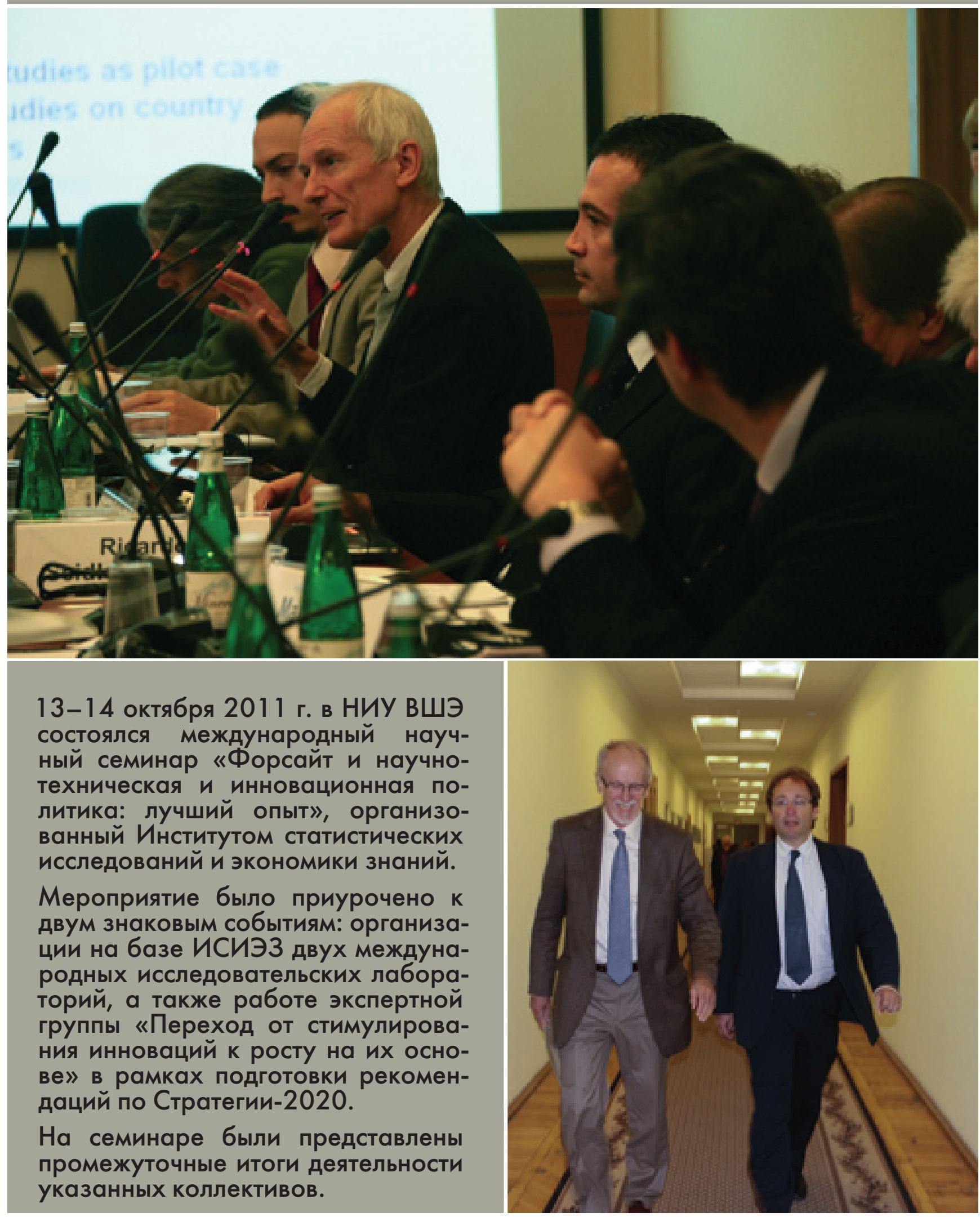


ткрывая работу семинара, Леонид Гохберг, первый проректор Высшей школы экономики и директор Института статистических исследований и экономики знаний (ИСИЭЗ НИУ ВШЭ), подчеркнул, что мероприятие носит во многом этапный характер, будучи связанным с двумя событиями 2011 г.

Во-первых, в этом году в ИСИЭЗ НИУ ВШЭ были созданы две международные исследовательские лаборатории под руководством известных зарубежных ученых: Лаборатория экономики инноваций (проф. Йен Майлс) и Лаборатория исследований науки и технологий (проф. Жан Гине). На семинаре были представлены первые результаты реализуемых в рамках лабораторий исследовательских проектов.

Во-вторых, по поручению Председателя Правительства России НИУ ВШЭ совместно с РАНХиГС при Президенте РФ с начала года провели большую работу по подготовке предложений по новой стратегии социально-экономического развития России до 2020 г. Для этого были созданы экспертные группы по различным направлениям государственной политики общим числом 21. Одна из них - группа №5 «Переход от стимулирования инноваций к росту на их основе» - подготовила рекомендации по возможностям перевода экономики России на инновационную модель развития ${ }^{1}$. Обсуждению предварительных результатов этой работы была посвящена вторая сессия семинара.

Таким образом, как отметил Л. Гохберг, основой семинара стало сочетание исследовательской и экспертной повестки.

В первый день работы семинара его участники сфокусировались на обсуждении роли Форсайта в формировании научно-технологической и инновационной политики, лучших практик Форсайт-исследований в различных странах, а также вопросах прикладного Форсайта.

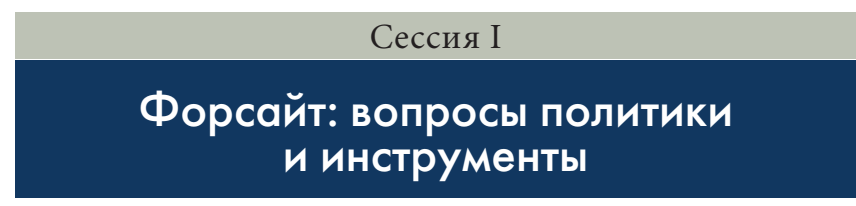

Модератор: Леонид Гохберг (НИУ ВШЭ)

Первый доклад семинара, представленный заведующим Лабораторией экономики инноваций ИСИЭЗ НИУ ВШЭ Йеном Майлсом, был посвящен подходам к измерению успешности и эффектов Форсайт-исследований. Первый вопрос, который докладчик предложил для обсуждения, был связан с пониманием терминов «измерение», «успех», «влияние» и «Форсайт». Что должно быть измерено - соответствие целей и результатов? Какие критерии подходят для этого? Что понимается под «Форсайтом» и его эффектами? Й. Майлс специально подчеркнул, что в настоящее время Форсайт превратился в определенный бренд, под который подводится самая разнообразная активность по исследованию будущего, в том числе и традиционное прогнозирование.
Успешность Форсайт-исследований также может рассматриваться с разных точек зрения. Библиометрический анализ использования термина «Форсайт-программа» в научной литературе показывает, что сегодня Форсайт считается общепризнанным инструментом формирования научно-технической и инновационной политики многих стран. Однако, как подчеркнул докладчик, интегрировать Форсайт в процесс принятия политических решений достаточно сложно, поскольку речь идет о необходимости координации различных фаз самого Форсайта и процесса формирования политики, а также учета большого количества внешних взаимосвязанных факторов. В любом случае прогнозы должны быть адаптированы к политическому циклу и потребностям лиц, принимающих решения, что определяет рамки реализации Форсайт-проектов, состав его участников, используемую методологию. Только в этом случае появляется шанс получить ответы на актуальные политические вопросы.

Научный сотрудник Университета Манчестера Рафаэль Поппер рассказал о новых инструментах и тенденциях развития Форсайт-исследований. В концептуальном контексте здесь сформировались два перспективных направления: сканирование горизонтов (мониторинг, определение и анализ зарождающихся трендов) и выявление слабых сигналов (знаковых событий, являющихся первыми признаками серьезных перемен в будущем). Важной тенденцией, по мнению докладчика, является разработка критериев для оценки национальных Форсайт-программ. Р. Поппер представил список из 20 критериев. Десять из них носят общий характер; пять - помогают выявить эффекты для научно-технической и инновационной политики; остальные пять - оценить вклад таких программ в развитие общества, основанное на знаниях. Другой интересный тренд - повышение роли количественных методов, их более широкое использование при разработке методологии Форсайта (например, известный «Форсайт-ромб» был дополнен методами математического моделирования, регрессионного анализа и др.). В заключение докладчик рассказал о таких новых исследовательских инструментах, как анализ социальных сетей с целью выявления взаимодействия между исследовательскими областями и игроками, а также подходы, позволяющие определять наиболее эффективные сочетания различных методов Форсайта.

Заместитель заведующего Лабораторией науки и технологий ИСИЭЗ НИУ ВШЭ Дирк Майснер представил первые результаты разработки методологии оценки эффективности Форсайт-проектов с точки зрения их выполнения, итогов и влияния на формирование научно-технологической и инновационной политики. Методология включает в себя шесть последовательных этапов: проверка проекта на принадлежность к категории Форсайт-исследований по специальным критериям; характеристика и классификация проекта; анализ по ключевым блокам (цели, заказчик, исполнители, привлекаемые эксперты, методология и т. п. рассматриваются на основе соответствующих признаков с указанием метода и шкалы оценивания); изучение

Подробнее см. статью «Стратегия-2020: новые контуры российской инновационной политики» в данном номере (с. 8-30), 
эффективности и результативности проекта; SWOTанализ; итоговая оценка и подготовка рекомендаций. В завершение докладчик отметил, что представленная методология будет дорабатываться и апробироваться на примере российских Форсайт-исследований.

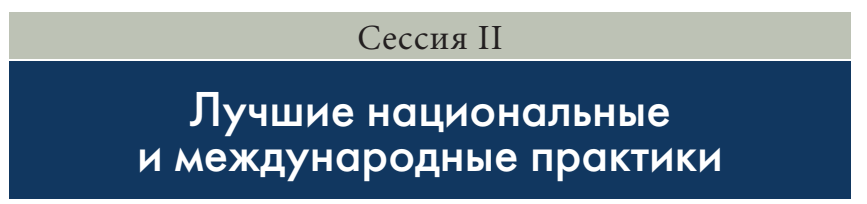

Модератор: Люк Джорджиу
(Университет Манчестера, Великобритания)

Директор по политике и стратегическому планированию Совета Мальты по науке и технологиям Дженнифер Харпер посвятила свой доклад опыту Европейского союза по применению результатов Форсайтисследований в процессе формирования и реализации государственной политики. Были раскрыты ключевые причины, препятствующие либо способствующие интеграции результатов Форсайта в процесс принятия управленческих решений. По мнению докладчика, принципиально важным является соответствие границ и методологии Форсайт-исследования контексту, в рамках которого оно проводится. Например, при реализации Форсайт-проектов в малых странах особое внимание следует уделить их специфике, существующему политическому курсу, балансу интересов, культурным традициям и возможностям наращивания имеющегося потенциала. В ЕС Форсайт используется как для информирования политиков, так и для гармонизации политики, осуществляемой государствами - членами союза. Дж. Харпер продемонстрировала несколько конкретных примеров использования Форсайта в процессе реализации политики ЕС. В частности, эта методология была использована для разработки эффективных научно-технических и инновационных программ развития стран - новых членов сообщества.

Заместитель директора ИСИЭЗ НИУ ВШЭ Александр Соколов проиллюстрировал особенности проведения Форсайт-исследований в России, использования их результатов в процессе формирования научно-технической и инновационной политики. Форсайт-методология развивается в России более 15 лет. За это время была реализована целая серия работ, включая разработку критических технологий (КТ) и приоритетных направлений (ПН) развития науки и технологий (действующий список ПН и КТ был утвержден Президентом РФ в июле 2011 г.). Были проведены два цикла долгосрочного научно-технологического прогноза, результаты которого послужили обширным информационным источником при разработке стратегий развития отдельных отраслей, перечня важнейших ИиР и других документов. В настоящее время стартовал третий раунд прогноза. Причем, в отличие от предыдущих, он нацелен на использование полученных результатов на практике. Имеется в виду не только информирование политиков и управленцев о ситуации в сфере науки и технологий, важнейших технологических трендах, но и непосредственная интеграция прогнозных оценок в процесс формирования и реализации государственной политики.
В развитие темы научный сотрудник Университета Манчестера, главный редактор британского журнала «Foresight» Озчан Саритас осветил вопросы интеграции системного и синергетического Форсайта (systemic and synergistic Foresight). О. Саритас описал основные требования к Форсайту, предъявляемые экономикой и обществом, сформулировал ключевые элементы концепции системного и синергетического Форсайта и его фазы. В числе важнейших этапов Форсайта докладчик выделил формирование общего представления о перспективах («образе») будущего; выявление связанных с ними приоритетов; интеграцию результатов Форсайта в долгосрочные национальные программы; разработку на его основе перечня конкретных действий, которые должны быть предприняты в краткосрочной перспективе для достижения поставленных стратегических целей. Для иллюстраций возможностей предложенного подхода докладчик рассмотрел Форсайт-проекты для малых стран, а также перспективы применения Форсайта, адаптированного под конкретного потребителя (customizing Foresight).

Завершая работу сессии, заместитель министра образования и науки Российской Федерации Алексей Пономарев отметил принципиальное значение Форсайта для разработки политики в сфере науки и инноваций, в частности - для выбора научно-технологических приоритетов. В настоящее время прогнозные работы ведут ряд федеральных органов исполнительной власти - Министерство здравоохранения и социального развития, Министерство промышленности и торговли, Министерство связи и массовых коммуникаций, Министерство энергетики Российской Федерации, а также государственные корпорации и компании. В этой связи особую важность приобретает вопрос согласованности их усилий. Широкий круг работ нацелен на получение объективной оценки состояния и перспектив развития исследований, прежде всего, находящихся на доконкурентной стадии и носящих задельный характер. Долгосрочный прогноз научно-технологического развития Российской Федерации позволит сформировать видение будущего отечественной науки на 20-летнюю перспективу; поддерживать на постоянной основе диалог с ведущими организациями и специалистами по вопросам обоснования научно-технологических приоритетов; учитывать мнение экспертного сообщества, представителей науки и бизнеса. Третий раунд прогноза будет еще сильнее интегрирован в практику: тематика поисковых исследований, установленная в будущей государственной программе «Развитие науки и технологий» на 2013-2020 гг., формируемой в настоящее время, будет основана на результатах прогноза.

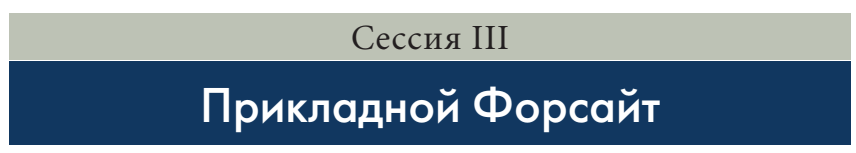

Модератор: Йен Майлс (Лаборатория экономики инноваций ИСИЭЗ НИУ ВШЭ; Университет Манчестера, Великобритания)

Первым в третьей сессии выступил экс-глава отдела технологического Форсайта ЮНИДО Рикардо Зейдль да 
Фонсека, который привлек внимание участников семинара к межстрановым Форсайт-проектам (multi-country Foresight) и его возможностям, в частности к синергетическому эффекту от использования совместной инфраструктуры исследований, изучения лучших мировых практик государств - участников соответствующих проектов. Докладчик рассказал об опыте ЮНИДО в области межстранового Форсайта, остановившись более подробно на ряде региональных проектов - «Будущее рыбной промышленности Тихоокеанского побережья Южной Америки», «Будущее пищевой промышленности в странах Центральной и Восточной Европы» (с участием Болгарии, Хорватии, Чехии, Венгрии, Румынии и Словакии) и др.

Заместитель директора Форсайт-центра ИСИЭЗ НИУ ВШЭ Олег Карасев посвятил свой доклад отраслевым Форсайт-исследованиям на примере изучения перспектив развития наноиндустрии. Высшая школа экономики провела крупномасштабные работы в этой области по заказу ОАО «Роснано», в которых приняли участие свыше тысячи российских экспертов, представляющих более 250 организаций из 30 регионов страны, а также более ста зарубежных специалистов. Целью проекта стало выявление перспективных направлений развития рынков сферы нанотехнологий на период до 2030 г., а также продуктовых групп, которые обладают наиболее высоким инновационным и рыночным потенциалом. Результаты исследования показали, что объем общероссийского рынка продуктов наноиндустрии к 2015 г. может составить порядка 3 трлн руб.; в ближайшие 20 лет прогнозируется его рост более чем в 6 раз (в сопоставимых ценах). Перспективными сферами применения продуктов, связанных с нанотехнологиями, в долгосрочном периоде будут электроника, автомобильная промышленность, дорожная инфраструктура, медицинская и фармацевтическая промышленность, энергетика, строительный комплекс. Исследование доказало принципиальную важность инновационной активности и в низкотехнологичных секторах. Здесь будет генерироваться спрос на продукцию наноиндустрии массового назначения с широким охватом различных категорий потребителей. К сожалению, как подчеркнул докладчик, во многих сегментах наноиндустрии наблюдается нарастающее отставание уровня российских разработок, ориентированных на долгосрочные перспективы коммерциализации.

С заключительным докладом первого дня выступил профессор Университета Оттавы Джонатан Кэлоф. Он представил свой взгляд на возможности интеграции Форсайта и «конкурентной разведки» (competitive intelligence) в контексте разработки планово-программных документов. Данная тематика является относительно новой, поэтому докладчик сначала рассказал об основных методах «конкурентной разведки», включающих изучение конкурентных позиций, отраслевой анализ, сегментацию групп потребителей и их ценностных установок. Дж. Кэлоф выделил виды управленческих решений, базирующихся на выводах «конкурентной разведки». Среди них - разработка корпоративной стратегии, принятие решений о выходе на новые рынки, слияниях и поглощениях и т.д. Рассмотрев преимущества Форсайта и «конкурентной разведки», докладчик сделал вывод о целесообразности комбинации двух подходов, которые в совокупности позволяют учесть особенности внешней среды, а также обеспечить принятие обоснованных решений по подготовке программ поддержки исследований и разработок, выделению приоритетных направлений инвестирования.

Тематика второго дня семинара объединила вопросы мониторинга состояния и эффективного государственного регулирования сферы науки, технологий и инноваций. На сессиях были представлены результаты деятельности экспертной группы №5 «Переход от стимулирования инноваций к росту на их основе», созданной для разработки рекомендаций по стратегии социально-экономического развития РФ до 2020 года. Также обсуждались российский и международный опыт формирования инновационной политики, ключевые барьеры для эффективного регулирования в инновационной сфере и пути их преодоления.

Во вступительном слове Ольга Кочеткова (Департамент стратегического управления (программ) и бюджетирования Минэкономразвития России) остановилась на ключевых вопросах отечественной инновационной политики и отметила значимость перехода к инновационной модели развития как наиболее перспективного варианта, обеспечивающего устойчивость долгосрочного роста российской экономики.

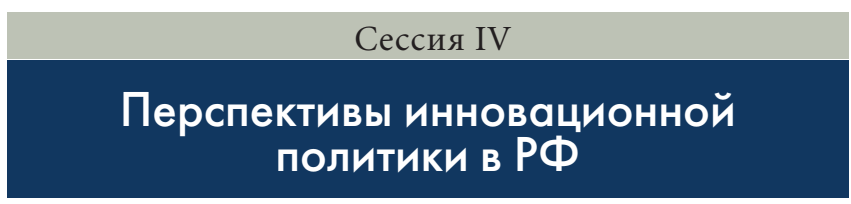

Модератор: Игорь Агамирзян

(Российская венчурная компания)

Открывая сессию, Игорь Агамирзян подробно рассказал слушателям о деятельности экспертной группы №5. В фокус работы экспертов попали актуальные вопросы обеспечения инновационного характера социально-экономического развития страны. В процессе практических обсуждений стало абсолютно понятно, что тематика экономического роста, базирующегося на инновациях, является горизонтальной и, очевидно, самым тесным образом связана с областями интересов практически всех экспертных групп, работающих над новой стратегией. Помимо сферы науки и технологий, успех инновационного роста зависит от инвестиционного и делового климата; многих аспектов налоговой политики и различных инструментов государственного стимулирования; наличия (отсутствия) административных барьеров; культурных традиций (отношение населения к предпринимательству, мотивация подготовки исследовательского и инженерного персонала, развитие базовых знаний о современных экономических и технологических трендах у участников инновационных процессов).

Остановившись на проблемах интеграции России в глобальную экономику, докладчик подчеркнул критическую важность повышения уровня взаимодействия с другими национальными экономиками для ускорения 
экономического роста, базирующегося на технологиях. Одним из ключевых ограничений для отечественной экономики выступает низкий уровень передела, сохранение роли поставщика ресурсов для зарубежных стран и компаний. Это делает страну в значительной мере зависимой от внешней конъюнктуры, что, в частности, проявилось во время начавшегося в 2008 г. мирового финансово-экономического кризиса. Интеграция на более высоких уровнях, включенность национальных производителей в глобальные цепочки добавленной стоимости повышает стабильность развития. Этот процесс, к сожалению, на сегодняшний день находится на начальной стадии, но является абсолютно необходимым трендом и требует поддержки на уровне государственной политики.

Доклад Леонида Гохберга (НИУ ВШЭ) продолжил представление основных итогов деятельности указанной экспертной группы. Подготовленные ею материалы объединили подробный анализ ситуации в инновационной сфере и предложения по выбору стратегических целей и направлений развития государственной политики на новом этапе, а также конкретных инструментов регулирования, которые могут быть реализованы правительством уже в следующем году.

Говоря о ключевых вызовах и ограничениях, касающихся стратегического развития России, докладчик выделил усиливающуюся зависимость от внешней конъюнктуры и порождаемые этим социальноэкономические риски. Кроме того, России все сложнее адекватно реагировать на такие происходящие в мире явления, как ускорение процессов генерации новых знаний, развитие новых технологических направлений, появление и трансформация новых рынков, формирование нетрадиционных эффективных моделей сетевого взаимодействия при создании инноваций на глобальном и национальном уровне, сдвиги в практике социальной политики. Серьезными ограничениями являются также состояние самой инновационной сферы в России, наличие острых социальных проблем, дискриминации крупных социальных групп с точки зрения их доступа к новым технологиям и инновациям.

Очевидным достижением последних лет в России стала интеграция инновационных инициатив в число экономических и социальных приоритетов органов власти самого высокого уровня. Были запущены новые инструменты регулирования, предпринимаются попытки расширения круга игроков в инновационной сфере, повышаются масштабы бюджетного финансирования сектора исследований и разработок. В то же время сохраняется ряд достаточно серьезных и все еще нерешенных задач стратегической повестки. Прежде всего, речь идет об отсутствии четко сформулированных целей и долгосрочного видения; жестких бюджетных ограничениях и социальной ориентированности расходов; множественности и нескоординированности инновационных сигналов со стороны государства. На этом фоне наблюдаются явно завышенные ожидания политиков в контексте масштабов и скорости достижения эффектов тех или иных решений. Принципиально важно понимать, что переход к инновационной экономике - длительный процесс, который вряд ли будет в полном объеме завершен в ближайшие 5-7 лет. При этом вопрос о том, сможет ли правительство последовательно придерживаться намеченных ориентиров, обеспечивать преемственность запланированных действий, остается открытым.

Экспертная группа предложила для рассмотрения три возможных сценария поведения в инновационной сфере. Первый - инерционный, ориентированный на низкие темпы экономического роста, сохранение сырьевой ориентации экономики, что не исключает продолжения «мягких» реформ в сфере науки и инноваций. Противоположностью ему может стать прогрессорский вариант, предусматривающий форсированное встраивание в глобальные процессы, переход к постиндустриальному этапу развития экономики. Дополнительно рассматривается умеренный сценарий, вероятность практической реализации которого достаточно высока. Различия в сценариях означают политический выбор в пространстве ключевых развилок. Так, в сфере образования альтернативами являются ситуационная настройка образовательных программ в соответствии с возникающими потребностями экономики или радикальная интенсификация развития профессиональных компетенций на базе модернизации образовательных программ, прежде всего по инженерии, менеджменту, а также воссоздание элитной инженерной подготовки. В области регулирования выбор должен осуществляться между продолжением практики ручного управления экономикой, в том числе в инновационной сфере, и акцентом на системные институциональные реформы, нацеленные на создание благоприятной среды для развития инноваций. В сфере законодательства рассматривается возможность последовательного перехода от мягкой реформы корпоративного и других отраслей законодательства (в рамках традиционной правовой системы) к его существенной модернизации, включая серьезное совершенствование судебной системы, ограничение прав силовых ведомств и др. В сфере науки важно окончательно определиться: продолжать ли ставшую традиционной практику последних 20 лет (консервация базовых институтов, реализация отдельных точечных решений в тех или иных секторах, выращивание альтернативных или параллельных исследовательских структур) либо ускорить комплексное реформирование государственного сектора науки на базе оценки результативности деятельности научных организаций.

Эксперты выделили несколько ключевых направлений в области собственно инновационной политики. Во-первых, целесообразно постепенно отойти от практики поддержки отдельных инновационных проектов в рамках жестко установленных технологических приоритетов к стимулированию массовых инноваций во всех секторах экономики, включая низкотехнологичные, создать благоприятную среду для инновационных компаний. Во-вторых, эффективная инновационная политика не может опираться исключительно на универсальный для всех секторов набор приоритетов, критериев, инструментов. Как показывает лучший мировой опыт, при ее реализации, безусловно, важен учет специфики рынков и отраслей, типов инновационного поведения компаний, природы различных видов экономической деятельности (структура издержек, стратегии развития и др.). В-третьих, серьезное значение имеет рациональное распределение усилий между поддержкой 
высокотехнологичных секторов предыдущей и новой технологической волны (новый хай-тек, сфера услуг, зеленые технологии и т. д.), а также инновационной активности в низкотехнологичных секторах. В-четвертых, современная политика означает отказ от жесткой иерархической организации управления «сверху вниз» в пользу децентрализации, передачи полномочий регионам, институтам развития, бизнес-ассоциациям и др.; поддержку сетевой кооперации на всех уровнях. B-пятых, должна, несомненно, возрасти роль экономических критериев (ориентация на результат) при принятии решений, фактора сбалансированности между тематическими и функциональными приоритетами политики, нацеленными на ликвидацию различного рода провалов в инновационном цикле.

В заключение Л. Гохберг отметил значимость столь актуальной для России тематики, как социальные эффекты инновационной политики, включая развитие практики инклюзивных инноваций, поддержку креативного класса, расширение программ подготовки кадров предпринимателей, менеджеров и профессионалов для инновационной сферы и экономики в целом.

Продолжил сессию Даниэл Малкин (ОЭСР), который представил подробную рецензию на материалы экспертной группы. В качестве отправной точки для анализа полноты и качества сформированной системы рекомендаций Д. Малкин выбрал доклад ОЭСР, посвященный развитию инновационной системы и инновационной политики России, подготовленный в 2009-2010 гг. и представленный на суд профессионального сообщества в 2011 г.

По признанию докладчика, подходы, использованные в обоих случаях близки. Основное различие между рамочным анализом в проекте ОЭСР и исследованиях экспертной группы заключается в разных акцентах на общих принципах регулирования, а также в уровне детализации инструментария политики.

Д. Малкин в целом согласился с общим мнением экспертной группы о важности выбора прогрессорского сценария для достижения амбициозных целевых ориентиров развития российской экономики и инновационной системы. Только этот вариант может обеспечить, несмотря на очевидные трудности, устойчивый прогресс страны. Критическим условием достижения нового качества государственной политики в сфере науки и инноваций докладчик считает обеспечение ее межведомственного характера, гармонизации позиций различных ведомств, институтов развития и др. Еще одна центральная задача - преодоление инерционности экономических акторов, их своего рода «идиосинкразии» к инновационной модели поведения. В отличие от стран, ранее продемонстрировавших заметные успехи в области инноваций (Финляндии, Кореи и др.), в России экономическое развитие происходит не «с чистого листа», а через трансформацию сложившихся институтов, что приводит к существенному замедлению и удорожанию реформ. Для разрешения этого противоречия целесообразно создать коалицию «во имя перемен» - совокупность участников, заинтересованных в успехе реализации инновационных инициатив.
Важной темой для дальнейших дискуссий докладчик назвал вопрос степени «кастомизации» управленческих решений. По его мнению, зрелые рыночные механизмы, а также рамочные условия, обеспечивающие массовизацию инноваций во всех секторах экономики, подразумевают большую унификацию мер поддержки. При этом в более централизованных системах управления баланс между унификацией регулирования и индивидуальной настройкой может смещаться.

Д. Малкин сформулировал проблему диалога с «протестными» группами, выявленными в процессе экспертного анализа. Такой контакт должен состояться при любом развитии событий, а задача его налаживания ложится на плечи политиков, заинтересованных в реализации эффективных реформ. Проблемы преодоления фрагментации инновационной системы, конфликтов интересов и определенного консерватизма участников делают осуществление комплексной и сбалансированной инновационной политики непростым, но, очевидно, необходимым делом.

В дискуссии по материалам экспертной группы приняли участие Филипп Шапира (Технологический институт штата Джорджия, США), Владимир Майер (Национальный центр научных исследований Франции), Татьяна Чернявская (ЮНИДО), Йен Майлс (ИСИЭЗ НИУ ВШЭ, Университет Манчестера) и другие специалисты, которые акцентировали внимание на таких вопросах, как расширение фондового финансирования науки; повышение роли частно-государственного партнерства для стимулирования спроса на инновации и поддержки их предложения; значимость социальных функций инновационной политики, включая развитие инклюзивных инноваций.

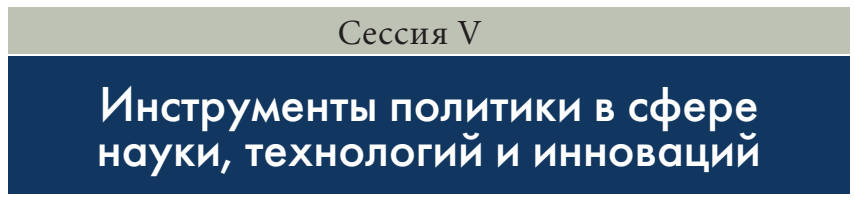

Модератор: Люк Джорджиу

(Университет Манчестера, Великобритания)

На сессии рассматривались вопросы развития научнотехнической и инновационной политики в контексте совершенствования инструментов ее реализации. Начальной точкой обсуждения стала проблема качественной трансформации результатов исследовательской деятельности в практические инновационные действия. Жан Гине (ИСИЭЗ НИУ ВШЭ) проиллюстрировал на примере США механизмы удачного «встраивания» политических решений в социально-экономический контекст и возможности формирования подобных конфигураций в России. Идея заключается в том, что на каждом историческом этапе требуются свои собственные «рычаги» для запуска инноваций при заданном уровне научно-технологического развития, сложившейся структуре национальных экономических и политических приоритетов. В процессе эволюции данные механизмы конструировались на базе различных теоретических концепций - линейной модели инновационного цикла, схемы «тройной спирали» (triple helix), открытых инновациий и др. Сегодня возможно и даже 
целесообразно комбинирование теоретических подходов при формировании политики в сфере науки и инноваций. С учетом специфики развития России выбор теоретической модели, равно как и инструментов регулирования, в национальном контексте должен во многом отличаться от подходов, практикуемых другими развитыми странами (например, членами ОЭСР). В связи с этим, по мнению докладчика, политики, управленцы, эксперты должны быть готовы к тому, что разработка и реализация необходимой для страны уникальной инновационной концепции будет таким же трудным и многообещающим вызовом, каким в свое время стал проект запуска первого искусственного спутника.

Павел Рудник (ИСИЭЗ НИУ ВШЭ) рассмотрел в своем докладе особенности реализации в России некоторых новых инструментов научно-технической и инновационной политики макроуровня (структурных, нормативных, стратегических - Форсайт-исследований, критических технологий, национальных исследовательских центров, институтов развития и пр.). Особое внимание было уделено опыту технологических платформ и программ инновационного развития государственных компаний. Как отметил докладчик, Россия в настоящее время столкнулась с необходимостью одновременно создавать адекватную теоретическую базу для уже существующей системы регулирования и эффективные средства перехода от макро-регуляторов к конкретным мероприятиям.

Наличие неблагоприятных социально-экономических условий, фрагментарность и нескоординированность мер научно-технической и инновационной политики заметно снижают эффективность ее реализации. Данная проблема может быть разрешена (по крайней мере, частично) при помощи встроенной системы мониторинга, развитого механизма технологического оценивания. Профессор Филип Шапира (Технологический институт штата Джорджия, США) рассказал участникам семинара об эволюции в США института распределенного технологического оценивания: от создания в 1974 г. единой Службы технологического оценивания (Office for Technology Assessment, OTA) до появления во второй половине 1990-х гг. распределенной сети оценивающих организаций. Политические функции соответствующих служб постоянно расширяются. Сегодня специализированные центры осуществляют деятельность по технологическому прогнозированию и формированию технологических дорожных карт, контролю в технологических цепочках, налаживанию коммуникаций между субъектами инновационных процессов, развитию интеллектуального потенциала в перспективных технологических направлениях и пр. Благодаря отраслевой и территориальной дифференциации институты оценивания обеспечивают реализацию адресных, гибких подходов к принятию политических решений. Общие принципы функционирования таких организаций были продемонстрированы докладчиком на примере Центра исследований нанотехнологий и специализированных структур Университета Аризоны (CNS-ASU).

Заключительный доклад сессии, представленный профессором Владимиром Майером (Национальный центр научных исследований Франции), был посвящен сопоставлению эволюции научно-технической и инновационной политики в России и Франции. Акцент был сделан на развитии российских университетов как ключевого сегмента сектора исследований и разработок. По сравнению с Францией доля вузов, вовлеченных в научную деятельность в России невелика, и они не объединены в кластеры (по территориальному признаку или по областям знаний), хотя, судя по французскому опыту, мощная государственная поддержка университетских кластеров могла бы стать одним из наиболее эффективных инструментов научной политики. Так, во Франции реализуются самые разнообразные государственные программы поддержки вузовской науки, включая развитие центров превосходства в вузах и научно-образовательных объединениях вузов и научных организаций. Докладчик подчеркнул, что в целом механизмы развития вузовской науки в России и Франции эволюционируют в одном направлении. Однако в России, очевидно, необходима более масштабная финансовая поддержка. В качестве альтернативных точек роста В. Майер рассмотрел аналоги «силиконовых долин» - «Сколково» в России и «Плато де Сакле» (Plateau de Saclay) во Франции. Основными факторами, препятствующими их развитию, в обоих случаях являются высокие риски создания центров превосходства «с нуля», сложность их интеграции в существующие научно-технологические сети.

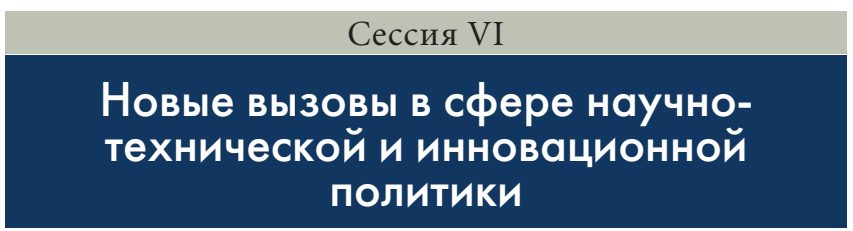

Модератор: Жан Гине (ИСИЭЗ НИУ ВШЭ)

Финальную сессию семинара открыл Майкл Кинэн (ОЭСР) с докладом, посвященным платформе ОЭСР по инновационной политике - новому инструменту для поиска эффективных решений и ответов на глобальные вызовы в сфере науки, технологий, инноваций. Речь идет о руководствах и информационных материалах для диагностики инновационных систем и выстраивания моделей взаимоувязанных инструментов регулирования (policy mix). Предлагаемый для широкого круга экспертов и стейкхолдеров из развитых и развивающихся государств онлайн-ресурс позволяет проводить дифференцированный анализ на национальном, региональном или секторальном уровне, учитывать различия в степени экономического развития. Основная цель создания такой информационно-аналитической площадки в ОЭСР - совершенствование актуальных стратегических установок и уточнение рамок регулирования; структурирование фрагментированной информационной базы знаний о динамике научно-технологических комплексов; создание условий для проведения международного бенчмаркинга регуляторов национальной инновационной системы. Важный аспект нового проекта ОЭСР инициирование коллективного обучающего процесса и обмена международным опытом разработки инновационной политики.

Методологический и понятийный аппарат платформы определяют исследования в области инноваций, 
социально-политический анализ, диагностика экономического роста, транзиционный менеджмент и футурология. Среди основополагающих принципов, которых придерживаются эксперты при разработке платформы, - необходимость учитывать различия в типах нововведений и целях инновационного роста; развивать проблемно-ориентированный подход; предлагать конкретные решения, основанные на качественных и количественных методах.

М. Кинэн подробно объяснил особенности структурного наполнения платформы; проиллюстрировал возможности отображения типологии и архетипов современных инновационных систем. Проект позволяет более наглядно идентифицировать их сильные и слабые стороны, пробелы в государственном регулировании, траектории желательных изменений и «коридоры возможностей» для инновационной политики, а также управлять процессом проведения реформ и оценивать их результаты.

В настоящее время в тестовом режиме функционирует сегмент платформы, посвященный развитию государственного сектора исследований и разработок. Осенью 2012 г. «инновационная» платформа станет доступной для большинства пользователей, при этом эксперты - модераторы из ОЭСР - будут контролировать качество поступающих предложений.

Европейский подход к анализу вызовов и задач в сфере науки и инноваций был представлен в выступлении сотрудника Института перспективных технологических исследований (Institute for Prospective Technology Studies, IPTS, Испания) Марка Бодена, который рассказал о направлениях и методах работы этой организации в рамках Объединенного европейского исследовательского центра (Joint Research Centre, JRC). Цель JRC - проведение для Еврокомиссии и правительств стран, входящих в ЕС, независимой научно-технической экспертизы инструментов регулирования, что позволяет добиться их более результативной имплементации. Созданный в 1994 г. IPTS изначально занимался изучением «возникающих технологий» (emerging technologies) и футурологическими исследованиями. Сегодня он специализируется на экономических и политических исследованиях по ряду направлений, которые отвечают задачам формирования доказательной политики ЕС (экономический и сценарный анализ, методы «затраты-выпуск», оценка чувствительности параметров, моделирование и др.).

Институт активно участвовал в разработке Лиссабонской стратегии и новой европейской стратегии «Европа-2020». Неудивительно, что большая часть проектов IPTS (25\% исследовательских работ) связана с изучением экономики знаний, взаимосвязи политики в сфере образования, науки и инноваций, регионального развития, т. е. приоритетных тем социально-экономической повестки ЕС. Среди прочих исследовательских направлений - изучение информационного общества (20\%); сельского хозяйства и развития сельскохозяйственных территорий $(20 \%)$; согласование промышленной и потребительской политики с приоритетами устойчивого развития (20\%); изменение климата, энергетика и транспорт (15\%). Форсайт-исследования проводятся, как правило, в рамках региональных программ и Седьмой рамочной программы ЕС. В плане текущих и перспективных работ - участие в поддержании информационной он-лайн платформы Еврокомиссии ERAWATCH (информация об участниках, программах и регулирующих мерах в сфере науки в ЕС и за его пределами); развитие информационно-аналитической площадки NETWATCH (информация о национальных программах в области исследований и разработок, возможностях сотрудничества на европейском уровне).

Институт отвечает на все запросы Еврокомиссии на проведение исследований в ключевых сферах политики и законодательства, развивает проекты передачи и структурирования знаний через информационноаналитические площадки, ведет футурологические исследования, направленные на анализ инструментов регулирования, ориентированных на решение новых глобальных задач и удовлетворение потребностей общества.

Проблема финансирования науки стала темой выступления Томаса Гштраунталера (ИСИЭЗ НИУ ВШЭ). Поиск новых источников в данной области сегодня считается одним из важных вызовов научно-технической и инновационной политики в условиях бюджетных ограничений. Особую актуальность он приобрел в России, где отток капитала в 2010 г. составил более 16 млрд долл. Т. Гштраунталер охарактеризовал ситуацию на внутреннем фондовом рынке и пояснил, что российские компании имеют пока мало шансов генерировать новый капитал на международном рынке. K тому же с учетом общей ситуации на мировых фондовых биржах американские облигации по-прежнему остаются более привлекательными по сравнению с акциями компаний из стран с развивающейся экономикой, что, собственно, и определяет направления международных валютных потоков. Для обеспечения стабильного финансирования науки в посткризисных условиях в российском контексте, где частный капитал слабо вовлечен в инновационные процессы, важно четко осознавать границы потенциальных источников внешнего финансирования, осваивать методы управления рисками в области обменных курсов, а также расширять возможности привлечения венчурного капитала, в том числе в общественном секторе.

В завершающем докладе профессора Люка Джорджиу (Университет Манчестера, Великобритания) были обобщены итоги работы семинара, систематизированы ключевые стратегические вызовы и развилки в сфере научно-технической и инновационной политики. Они связаны с такими аспектами регулирования, как избирательность приоритетов, концентрация ресурсов и обеспечение устойчивого развития сферы науки. Проблема избирательности заключается в сложности выбора направлений исследований, по которым будет оказываться государственная поддержка. В практике ЕС для этого используется подход, включающий несколько аналитических стадий. В первую очередь идентифицируются социальные, а также так называемые «большие» вызовы (grand challenges) и приоритеты. Этот процесс организуется «сверху-вниз». Затем определяются ключевые технологии; причем структурирование приоритетов происходит по принципу «снизу-вверх». Ключевые вызовы могут выявляться на основании их 
принятия («легитимизации») широкой общественностью - например, изменение климата, распространение эпидемических болезней и др. - либо оценки их потенциального разрушающего эффекта. В любом случае на данном этапе поступающие сигналы анализируются на агрегированном уровне. Этот методологический принцип Л. Джорджиу назвал «гранулированным» подходом, при котором артикуляция вызовов является своего рода компромиссом между слишком общим или чересчур конкретным определением вызова.

Учитывая специфику глобальных вызовов, фактиче ски невозможно (либо, как минимум, весьма рискованно) формально исключать отдельные проблемные аспекты из фокуса регулирования. В то же время рассмотрение тех или иных вызовов может происходить по мере «созревания» соответствующих решений. Избирательность приоритетов в данном случае - не что иное, как опреде ление некой последовательности мер («aligning not selecting»). В условиях бюджетных ограничений за этим этапом следуют перегруппировка ресурсов и поиск дополнительных источников финансирования. Как подчеркнул докладчик, при этом часто упускается из виду взаимосвязь вызовов и, соответственно, необходимость взаимоувязки возможных решений. Оптимальный уровень специализации и приоритезации в научнотехнической сфере остается, таким образом, открытым вопросом для исследователей.

Концентрация ресурсов в «элитных институтах» является неизбежным следствием распределения финансирования в зависимости от качества результатов. Возникающие здесь проблемы очевидны. Например, на индивидуальном уровне (продвижение отдельных исследователей) возникают барьеры для входа новых участников. Подобное структурное неравенство закрепляется и на региональном уровне. Так, на Калифорнию приходится более пятой части затрат США на науку; 20 лидирующих штатов осваивают 85\%, а 20 аутсайдеров - всего 4\% этих затрат. Аналогичное неравенство существует и в Европе, где аутсайдерами в распределении ресурсов в сфере науки являются 12 новых стран членов ЕС.

Рассуждая о выборе между стимулированием «спилловеров» и созданием критической массы игроков, Л. Джорджиу показал, что важную роль в науке играют эффекты экономии от масштаба. С этим часто связана более высокая эффективность крупных научных организаций. Но как обеспечить устойчивость развития всего научно-технического комплекса? Достоинства и недостатки конкурсного и институционального финансирования, демографические вызовы и сложность восстановления исследовательских компетенций, возрастающая капиталоемкость оборудования, появление сетевой инфраструктуры — все эти вопросы требуют соответствующих решений в области финансового и инфраструктурного обеспечения, подготовки кадров и т. д.

Что касается инновационной политики, то ее современная повестка, по мнению докладчика, базируется на следующей системе взглядов. Во-первых, это постулирование важности политики, ориентированной на спрос (demand-side innovation policy), и поддержка инноваций, инициированных пользователями (user innovation). Во-вторых, меры регулирования должны быть адаптированы к тому, что появление нововведений не всегда связано с исследованиями и разработками. Для старта может быть достаточно новых технологических возможностей, потенциала организационных и социальных инноваций, развитого сектора услуг. В-третьих, экспертное сообщество все чаще обсуждает инициативы государства в контексте не только «открытых инноваций», но всей их «экосистемы». Так, в рамках «всеобъемлющей» инновационной политики (broad-based innovation policy) вызовы оцениваются сразу по нескольким направлениям: формирование рамочных условий; поиск источников финансирования; подготовка кадров и развитие человеческого капитала; стимулирование спроса; поддержание здоровой конкурентной среды для бизнеса; развитие инфраструктуры (доступность венчурного капитала, технологической и информационной инфраструктуры и др.); обеспечение мобильности (знаний, людей, капитала, услуг).

Л. Джорджиу привел несколько известных примеров, иллюстрирующих провалы в регулировании сложной инновационной экосистемы: поддержка малого бизнеса без учета его тесного взаимодействия с крупными компаниями; прямолинейная ориентация поддержки хай-тека исключительно на высокотехнологичные сектора; игнорирование потенциала применения хай-тека в традиционных секторах (сельское хозяйство и др.). Для коррекции этих ошибочных подходов, как указал докладчик, важно интегрировать весь спектр разнообразных научных результатов и инноваций.

Если координация является ключевой установкой горизонтального регулирования в сфере науки и инноваций, то не менее важна, по мнению докладчика, интеграция стейкхолдеров, областей регулирования, групп-бенефициаров и др.

Таким образом, перед научно-технической и инновационной политикой стоит важнейшая задача поиска целого спектра «правильных» балансов - между поддержанием рационального уровня конкуренции и сотрудничества; краткосрочными и долгосрочными приоритетами; эффективностью национальной и региональных инновационной систем; стабильностью и динамизмом развития; концентрацией и междисциплинарностью и т. д. В заключение Л. Джорджиу отметил, что, несмотря на доминирование концепции национальных инновационных систем как аналитической парадигмы в теории инноваций уже на протяжении почти четверти века, системные характеристики редко становятся предметом анализа при разработке политики. В качестве первого шага на пути к улучшению этого процесса было предложено сосредоточиться на определении международно-сопоставимого инструментария по измерению системных условий инновационных систем и их связи с общей эффективностью экономики.

Материал подготовили К.О. Вишневский, С.А. Зачченко, А.С. Зайиеља, В.А. Рудъ, А.В. Соколова. Фотографии предоставил М.Н. Кочемир. 


\section{СОДЕРЖАНИЕ За 2011 гоД}

Авторы и название статей ОТ РЕДАКЦИИ

№ Стр.

Журналу «Форсайт» — пять лет

СТРАТЕГИИ

Аренс М., Витшель М., Дётч К., Кревитт В., Маркевиц П., Мёст Д.,

Обершмидт Ю., Херкель С., Шойфен М.

Энергетические технологии 2050

14

Бойкова М.В., Ильина И.Н.,

Салазкин М.Г. Будущее городов: города

как агенты глобализации и инноваций

$4 \quad 32$

Паттнаик Б.К. Глобализация

промышленных исследований и

разработок: социологический аспект

Стратегия-2020: новые контуры

инновационной политики

\section{ИННОВАЦИИ И ЭКОНОМИКА}

Гштраунталер Т., Сагиева Г.С.

Интернационализация венчурного

капитала: вызовы и возможности

$4 \quad 66$

Дорошенко М.Е. Инновационный потенциал сектора интеллектуальных услуг в России

$4 \quad 50$

Зайцева А.С., Шувалова O.P. Новые акценты в развитии инновационной деятельности: инновации, инициируемые пользователями

Кузнецова T.Е., Рудь В.А. Факторы эффективности и мотивы инновационной деятельности российских промышленных предприятий

Майлс Й. Сервисные инновации в XXI веке

Медовников Д.С., Розмирович С.Д.

Технологические коридоры в производстве потребительской продукции и услуг

Рудник П.Б. Технологические платформыв практике российской инновационной политики

$1 \quad 16$

\section{HAYKA}

Гасслер Х., Шибани А. «Непрактичная» наука: как оценить результативность фундаментальных исследований

140

Кирчик О.И. «Незаметная» наука: паттерны интернационализации российских научных публикаций

Кузык М.Г. Оценка влияния экономического кризиса на государственные научные организации

148

Ле Гоэбель М., Пекарц Д., Хандлер К., Шух К. Научно-техническое сотрудничество ЕС и Украины: преимущества и барьеры
Авторы и название статей № Стр.

Позняк А.Ю., Шашнов С.А. Научно-

технологические приоритеты для

модернизации российской экономики

Шматко Н.А. Научный капитал как драйвер социальной мобильности ученых

$3 \quad 18$

МАСТЕР-КЛАСС

Бруммер В., Лиесио Ю., Ниссинен Ю.,

Сало А. Идентификация потенциальных

коллаборативных сетей в

международных научных программах 1156

Джонстон Р. Анализ технологий,

ориентированный на будущее:

«проблема Кассандры»

Нугрохо Я., Саритас О. Увидеть и осознать невидимое: сканирование, сетевой и сценарный анализ

\section{СОБЫТИЕ}

XII Международная научная конференция НИУ ВШЭ по проблемам развития экономики и общества. Семинар «Научно-техническая и инновационная политика»

Вторая российско-германская летняя школа «Проблемы научнотехнологического и инновационного развития»

Международный научный семинар «Форсайт и научно-техническая и инновационная политика: лучший опыт»

Франко-российская научнопрактическая конференция «Экономика, политика и общество: новые вызовы и перспективы». Семинар «Экономика науки, технологий и инноваций»

\section{МНЕНИЕ ЭКСПЕРТА}

Алфимов М.В. Эффективный Форсайт: симбиоз экспертизы и фактов

Джорджиу Л. Креативность и

взаимодействие: пространства роста для российского Форсайта

Шварц П. Инновации - залог стабильности в период кризиса
115,57 ,

33,57 ,

265,76

ИНДИКАТОРЫ 


\section{CONTENTS for 2011}

Authors and Paper Titles

No Page

EDITORIAL

Journal «Foresight»: Five Years

4

8

\section{STRATEGIES}

Arens M., Dötsch C., Herkel S.,

Krewitt W., Markevitz P., Möst D.,

Oberschmidt J., Scheufen M.,

Wietschel M. Energy Technologies 2050

1

Boykova M.V., Ilyina I.N., Salazkin

M.G. Urban Futures: Cities as Agents of

Globalization and Innovation

Pattnaik B.K. Globalization of Industrial

R\&D in Developing Countries:

A Sociological Perspective

$3 \quad 12$

Strategy 2020: New Outlines of Russian

Innovation Policy

\section{INNOVATION AND ECONOMY}

Doroshenko M.E. Innovative Potential of the Knowledge-Intensive Services Sector in Russia

Gstraunthaler T., Sagieva G.S. The

Internationalization of Venture Capital:

Challenges and Opportunities

Kuznetzova T.E., Roud V.A. Efficiency

Factors and Motivations Driving

Innovative Activity of Russian Industrial

Enterprises

234

Medovnikov D.S., Rozmirovich S.D.

Technology Corridors in the Production

of Commodities and Services

$1 \quad 26$

Miles I. Service Innovation in the Twenty First Century

Rudnik P.B. Technology Platforms in the Russian Innovation Policy Practice

Shuvalova O.R., Zaytseva A.S. Changing

Emphases in Innovation Activity: User

Innovation

SCIENCE

Gassler H., Schibany A. «Useless» Science:

How to Evaluate Performance of Basic

Research

Kirchik O.I. «Invisible» Science: Patterns of Internationalisation for the Russian

Scientific Publications

Kuzyk M.G. Economic Crisis:

Implications for Russian Science

$1 \quad 48$

INDICATORS

«Foresight and Science, Technology and

Innovation Policies: Best Practices»

2

66

French-Russian Academic Conference

«Economy, Policy and Society: New

Challenges and Prospects». Workshop

«Economics of S\&T and Innovation»

The Second German-Russian Summer

School «Science, Technology and

Innovation Development»

\section{EXPERT OPINION}

Alfimov M.V. An Efficient Foresight Study:

Mutualism of Expertise and Evidence

Georghiou L. Creativity and Interaction as Areas of Growth for the Russian Foresight 4

Schwartz P. Innovation as a Basis of

Stability in the Times of Crisis

and Scenario Analysis 366

R\&D Programmes $\quad 1 \quad 56$

Poznyak A.Yu., Shashnov S.A. S\&T

Russian Economy $\quad 2 \quad 48$

Driver of Researchers' Social Mobility $\quad 3 \quad 26$

Vissinen J.,

Collaboration Networks in International

Analysis: The Cassandra Challenge $\quad 2 \quad 58$

Nugroho Y., Saritas O. Seeing the

Fconomic and Social

Development. Workshop «S\&T and

Conference

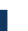

Le Gohebel M., Handler K., Pecarz D., Schuch K. S\&T Cooperation between the EU and Ukraine: Benefits and Barriers 


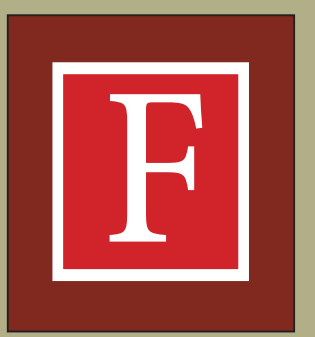

